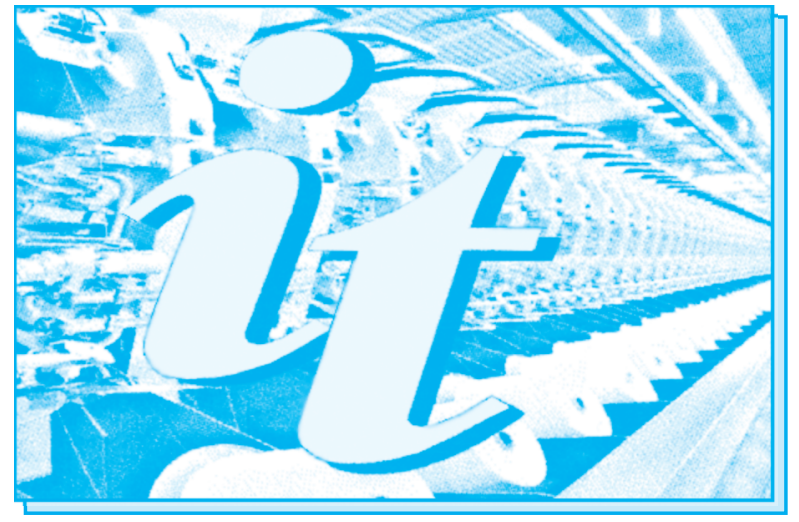

Revistă cotată ISI și inclusă în Master Journal List a Institutului pentru Știința Informării din Philadelphia - S.U.A., începând cu vol. 58 nr. $1 / 2007$

ISI rated magazine, included in the ISI Master Journal List of the Institute of Science Information, Philadelphia, USA, starting with vol. 58, no. 1/2007

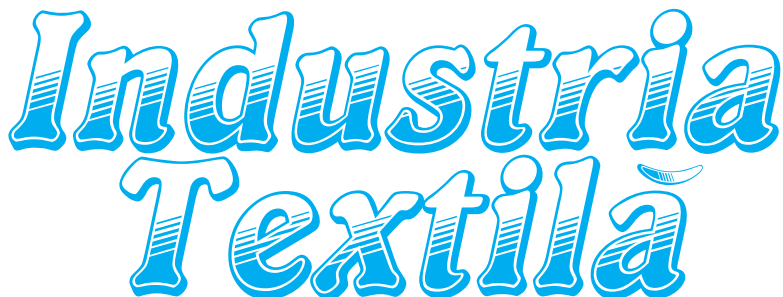

ISSN 1222-5347

\section{$1 / 2018$}

Editată în 6 nr./an, indexată si recenzată în

Edited in 6 issues per year, indexed and abstracted in:

Science Citation Index Expanded (SciSearch ${ }^{\circledR}$ ), Materials Science Citation Index ${ }^{\circledR}$, Journal Citation Reports/Science Edition, World Textile

Abstracts, Chemical Abstracts, VINITI, Scopus, Toga FIZ technik ProQuest Central

Editată cu sprijinul Ministerului Cercetării și Inovării

\section{COLEGIUL DE REDACTIE:}

Dr. ing. CARMEN GHITULEASA CS I - DIRECTOR GENERAL

Institutul Naţional de Cercetare-Dezvoltare pentru Textile şi Pielărie - Bucureşti

Dr. ing. EMILIA VISILEANU CS I-EDITOR SSEF

Institutul Naţional de Cercetare-Dezvoltare pentru Textile şi Pielărie - Bucureşti

Conf. univ. dr. ing. MARIANA URSACHE DECAN

Facultatea de Textile-Pielărie şi Management Industrial, Universitatea

Tehnică „Ghe. Asachi“ - laşi

Prof. dr. GELU ONOSE CSI

Universitatea de Medicină şi Farmacie "Carol Davila" - Bucureşti

Prof. dr. ing. ERHAN ÖNER Marmara University - Turcia

Prof. dr. S. MUGE YUKSELOGLU

Marmara University - Turcia

Prof. univ. dr. DOINA I. POPESCU Academia de Studii Economice - Bucureşti

Prof. univ. dr. ing. CARMEN LOGHIN

Facultatea de Textile-Pielărie şi Management Industrial, Universitatea

Tehnică „Ghe. Asachi“ - laşi

Prof. univ. dr. MARGARETA STELEA FLORESCU Academia de Studii Economice - Bucureşti

Prof. ing. ARISTIDE DODU

Membru de onoare al Academiei de Ştiinţe Tehnice din România

Prof. dr. ing. LUIS ALMEIDA

University of Minho - Portugal

Prof. dr. LUCIAN CONSTANTIN HANGANU Universitatea Tehnică „Ghe. Asachi“ - laşi

\section{Dr. AMINODDIN HAJI}

PhD, MSc, BSc, Textile Chemistry and Fiber Science Assistant Professor

Textile and Art Department Islamic Azad University, Birjand Branch Birjand, Iran
MUSADDAQ AZEEM, AMAL BOUGHATTAS, HAFIZ FAISAL SIDDIQUE, ANTONIN HAVELKA, SAJID HUSSAIN

Proprietățile de confort ale țesăturilor din nano-filament de poliester: evaluare senzorială

HÜSEYIN GAZI TÜRKSOY, TUĞBA AKKAYA, DENIZ VURUŞKAN, SÜMEYYE ÜSTÜNTAĞ

Analiză comparativă între proprietățile firelor filate cu jet de aer și proprietățile firelor filate cu inele

WANG YONG, YU WEIDONG, WANG FUMEI

Efectele variabilelor de prelucrare asupra proprietătilor fizice ale firelor compozite elastic conductoare tri-componente (t-ECCY) utilizând o mașină de filat cu inele modificată

LIHONG CHEN, HONG YU, XINFENG YAN

Dezvoltarea unei arhitecturi modulare în ceea ce privește siguranța îmbrăcămintei pentru managementul lanțului de aprovizionare

SUNHILDE CUC, SIMONA TRIPA

Reproiectare și reciclare - o soluție pentru competitivitatea întreprinderilor mici și mijlocii din industria de îmbrăcăminte

LIVIU TUDOR

O schimbare în industria textilă și de îmbrăcăminte

HAKAN ÖZDEMIR, BERKAY CAMGÖZ

Eficiența ecranării radiațiilor gamma a țesăturilor cu conținut de fire din oțel texturat

JAWAD NAEEM, ADNAN MAZARI, ENGIN AKCAGUN, ZDENEK KUS

Aerogeluri de $\mathrm{SiO}_{2}$ și aplicațiile acestora la temperatură ridicată

ADRIANA-IOANA SUBTIRICA, ANDREEA ANA-MARIA CHIVU, CRISTINA ANTONELA BANCIU, LAURENTIU-CHRISTIAN DINCA

Nanofibre obținute din polimeri biocompatibili și biodegradabili, cu potențial de utilizare ca textile medicale

YAN HONG, PASCAL BRUNIAUX, JUNJIE ZHANG, KAIXUAN LIU, MIN DONG, YAN CHEN

Aplicații ale proiectării îmbrăcămintei 3D-2D pentru morfologia atipică: un caz de proiectare pentru persoanele cu dizabilități fizice cu scolioză

ZOUHAIER ROMDHANI, MOHAMED HAMDAOUI, AMAL CHEBIL, MUSTAPHA JENDOUB

Efectul proprietăților pastei ca film de imprimare cu jet de cerneală și modelul matematic pentru urmărirea fenomenului cinetic al umectării

DIANA LORETA PǍUN, CONSTANTIN SORIN PǍUN, LAURENTIU ALEXANDRU CHIOTOROIU, EMILIA VISILEANU, SILVIA CHIOTOROIU Formalizarea cadrului conceptual-aplicativ al fibrelor textile inteligente în medicină

Recunoscută în România, în domeniul Stiintelor ingineresti, de către Consiliul Național al Cercetării Științifice din Învățământul Superior (C.N.C.S.I.S.), în grupa A /

Aknowledged in Romania, in the engineering sciences domain, by the National Council of the Scientific Research from the Higher Education (CNCSIS), in group $\mathbf{A}$ 


\section{Contents}

MUSADDAQ AZEEM, AMAL BOUGHATTAS, HAFIZ FAISAL SIDDIQUE,

ANTONIN HAVELKA, SAJID HUSSAIN

HÜSEYIN GAZI TÜRKSOY,

TUĞBA AKKAYA, DENIZ VURUŞKAN,

SÜMEYYE ÜSTÜNTAG

WANG YONG, YU WEIDONG, WANG FUMEI

LIHONG CHEN, HONG YU, XINFENG YAN

\section{SUNHILDE CUC, SIMONA TRIPA}

\section{LIVIU TUDOR}

\section{HAKAN ÖZDEMIR, BERKAY CAMGÖZ}

JAWAD NAEEM, ADNAN MAZARI, ENGIN AKCAGUN, ZDENEK KUS

ADRIANA-IOANA SUBTIRICA, ANDREEA ANA-MARIA CHIVU, CRISTINA ANTONELA BANCIU, LAURENTIU-CHRISTIAN DINCA

YAN HONG, PASCAL BRUNIAUX, JUNJIE ZHANG, KAIXUAN LIU, MIN DONG, YAN CHEN

\section{ZOUHAIER ROMDHANI,}

MOHAMED HAMDAOUI, AMAL CHEBIL, MUSTAPHA JENDOUBI

\section{DIANA LORETA PĂUN,}

CONSTANTIN SORIN PǍUN

LAURENTIU ALEXANDRU CHIOTOROIU,

EMILIA VISILEANU, SILVIA CHIOTOROIU
Comfort properties of nano-filament polyester fabrics: sensory evaluation

A comparative analysis of air-jet yarn properties with the properties of ring spun yarns

Effects of process variables on physical characteristics of tri-component elastic-conductive composite yarns (t-ECCYs) using a modified ring frame

Developing a modular apparel safety architecture for supply chain management: the apparel recycle perspective

Redesign and upcycling - a solution for the competitiveness of small and medium-sized enterprises in the clothing industry

Change in textile and clothing industry

The gamma radiation shielding effectiveness of textured steel yarn based fabrics

$\mathrm{SiO}_{2}$ aerogels and its application in fire fighter protective clothing

Nanofibres made from biocompatible and biodegradable polymers, with potential application as medical textiles

Application of 3D-to-2D garment design for atypical morphology: a design case for physically disabled people with scoliosis

Effect of paste properties as inkjet printing film and Mathematical Model to Follow the Kinetic of Wetting Phenomenon

Formalizing the conceptual-applicative framework of smart textile fibers in medicine

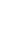

(1)




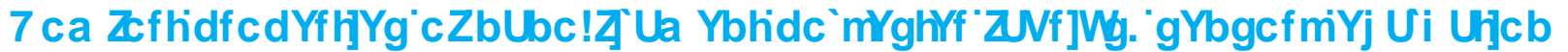

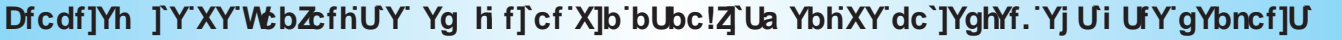

În acest articol, este prezentată o lucrare experimentală pentru evaluarea proprietăților senzoriale ale țesăturilor din nano-filament de poliester. În acest scop, o țesătură din nano-filament de poliester a fost realizată și comparată cu țesături din: amestec poliester/bumbac (PC) şi, respectiv, poliester/viscoză (PV), utilizând sistemul de evaluare Kawabata (sistemul KES), cu scopul de a evalua tușeul pe baza caracteristicilor mecanice. Rezultatele au arătat că țesăturile realizate în amestec PC și PV au fost mai rigide decât țesătura din nano-filament de poliester. O valoare mai mare a tușeului (THV) a dus la o rigiditate mai mică (Koshi), la o netezire (Numeri) și la un grad de umplere (Fukurami) mai mari. Valorile tușeului țesăturii din amestec PV au fost mai apropiate de cele ale țesăturii din nano-filament de poliester față de cele ale țesăturii PC. Rezultatele generale ale caracteristicilor de rezistență la tracțiune, forfecare, încovoiere, compresiune și de suprafață ale țesăturilor din nano-filament de poliester au fost mai bune în comparație cu cele ale țesăturilor în amestec PC și PV.

Cuvinte-cheie: confort senzorial, tușeul țesăturii, țesătură din nano-filament de poliester, țesătură în amestec PC și PV

\section{\&RP IRUNSURSHUHMRI QQDQRIILIPP HQUSRQHMMUIDEUFVIVHQVRU [HYDOXDURQ}

In this article, an experimental work is presented to evaluate the sensorial properties of polyester fabric constructed by nano-filament yarn. For this purpose Nano Filament polyester fabric was fabricated and compared with the spun polyester/cotton (PC) and polyester/viscose (PV) blended fabric by using Kawabata evaluation system (KES-system) to assess the handle of the fabric based on mechanical characteristic. The results revealed that the fabric made from PC and PV blended fabric were stiffer than nano-filament polyester fabric. The higher hand value (THV) resulted in lower stiffness (Koshi), and higher smoothness (Numeri) and fullness (Fukurami). Hand values of PV blended fabric were close to nano-filament polyester fabric rather than PC fabric. The overall results of tensile, shearing, bending, compression and surface characteristics of nano-filament polyester fabric were found best as compared to PC and PV blended fabric.

Keywords: Sensorial comfort, Fabric handle, Nano-filament polyester fabric, PC and PV blended fabric

\section{,1752 " $8 \& 7,21$}

Clothing comfort is divided into three categories like psychological, tactile and thermal comfort. Psychological comfort is usually concerned to the up to date fashion trend and acceptability in the society and also deals with the fabric properties. The tactile or sensorial comfort is interconnected with fabric surface and mechanical properties [1]. Sensorial evaluation plays a major role to identify the materials in addition for technical specification. All textiles material have different characteristic from each other with their technical structures like strength, performance flexible, elastic, easy to pleat and shape, comfortable in aesthetic and sensorial aspects. In order to find a procedure for the sensational evaluation of textiles, the term "fabric handle" is commonly used [2].

The fabric handle is defined as "total sensations being felt by human fingers during the fabric touching" [3]. This parameter is associated to the fabric properties, such as surface contour (roughness, smoothness), surface friction, resilience, flexibility, elasticity, compressibility, density and thermal character. Raw material, yarn and fabric structure as well as finishing treatment affect the THV (total hand value) [4-7].
Polyester fiber is one of widely consumed of all fibers (about 70\%). However, it is known by its hydrophobic (low moisture regain) and electrostatic nature. To obtain better moisture transport, researchers are thinking to modified polyester, especially with using multifilament and fine filament yarns [8-9].

Multifilament polyester yarns are made by aggregating many continuous filaments together. They are characterized by their high strength, good chemical properties, acceptable elasticity and its circular cross section. Moreover, the voids between these filaments form capillary channels and facilitate liquid flow. In knitted fabrics, using multifilament polyester yarns instead of monofilament can facilitate moisture transport and liquid absorption [10]. Fabric structure is also an important factor influences its mechanical properties. In knitting structure, the tightness factor affects the handle, stiffness increases with the increase of tightness of fabric which is related to bending rigidity. Fullness, softness and smoothness are inversely proportion to the tightness factor [11]. Nowadays we talk about ultra fine filaments or nanofilaments of polyester with diameters in the range of a few nanometers and lengths up to kilometers are used in different range of important technological 
applications such as functional fabrics, biomedicine, composite, etc. The nano-filaments of polyester are characterized by their high tenacity, large surface area per unit mass and small pore size [12]. Furthermore, they have high fibre interconnectivity and nano-scale inertial space compared to conventional multifilament of polyester. These properties will force the transfer of moisture away from the skin to the outside of the fabric because there is a good correlation between permeability and the inter-fibre and the intra-fibre voids of a tightly woven fabric [13]. THV is the measure of sensorial comfort designated with the use of Kawabata evaluation system (KES system) [3].

The use of multifilament yarn in fabric is also an important solution to replace cotton. In hard activity, when wearer get sweat suffers discomfort. To get rid of this problem multifilament polyester is a substitute material for him/her. Long capillaries provide better transportation and force the perspiration to be evaporated. Quick evaporation considers a main comfort character in warm weather. However, filament polyester fabric helps the drying of fabric in hot weather. The nano-filament fabric are very useful for the under garments especially gloves. Better water transport properties make it more useful for industrial point of view.

\section{MATERIALS AND METHODS}

\section{Material}

Nano-filament samples were got from a Japanese commercial factory to assess their comfort properties for next to skin fabric. Fabric SEM images are given in figure 1.

\begin{tabular}{|c|c|c|}
\hline Sample \# & $\begin{array}{c}\text { GSM } \\
\left(\mathrm{g} / \mathrm{m}^{2}\right)\end{array}$ & $\begin{array}{c}\text { Thickness } \\
(\mathrm{mm})\end{array}$ \\
\hline S1 & $200 \pm 2$ & 0.44 \\
\hline S2 & $250 \pm 2$ & 0.55 \\
\hline
\end{tabular}

Table 2

\begin{tabular}{|l|c|c|}
\hline Fineness & dtex & $152 \pm 10$ \\
\hline Tenacity & $\mathrm{N}$ & $4.5 \pm 0.3$ \\
\hline Elongation at break & $\%$ & $32 \pm 5$ \\
\hline Boil Shrinkage & $\%$ & $2 \pm 1$ \\
\hline
\end{tabular}

Both samples were made of the same yarn so the images presented the same filament diameter (table 1 and table 2).

\section{Methods}

The Kawabata evaluation system is used to measure the mechanical properties of fabrics [14]. The system was invented by a team under the supervision of Professor Kawabata in Kyoto University Japan. Kawabata evaluation system consists of four modules KES-FB1, KES-FB2, KES-FB3 and KES-FB4 for tensile/shearing, bending, compression and surface characteristic evaluation respectively.

KES-FB1 Tensile and Shear Tester; this module moves mechanically as shown in figure $3, a$. Data obtained from this system is helpful to determine stiffness and anti-drape stiffness. These characteristics are correlated with tendency for wrinkles and stability. KES-FB2 Pure Bending Tester; this module also performs mechanically as shown in figure $3, b$. Obtainable data includes bending rigidity and recoverability for

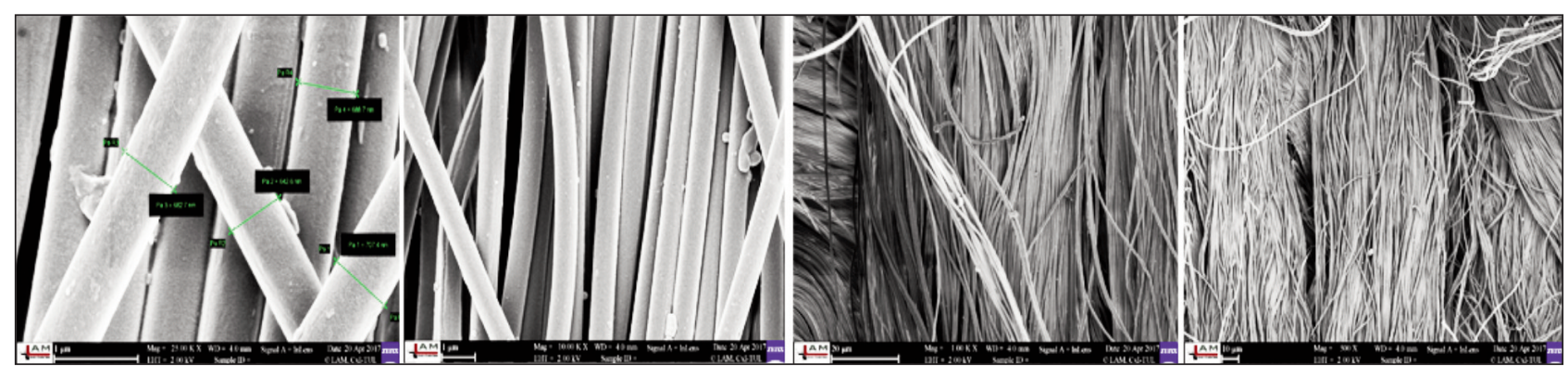

Fig. 1. SEM images of sample 1 with almost 680 nano-meter diameter

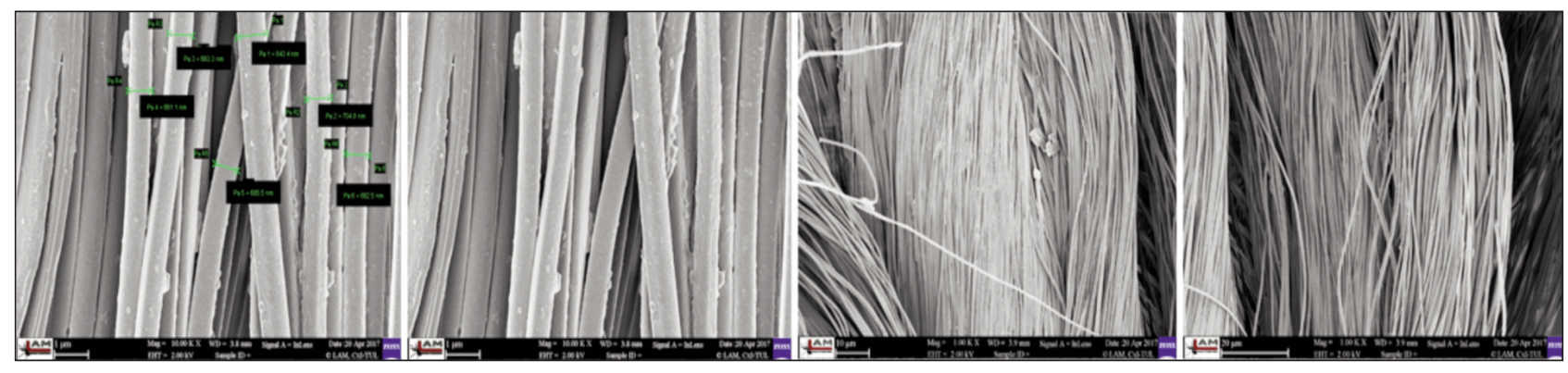

Fig. 2. SEM images of sample 2 with almost 670 nano-meter diameter 


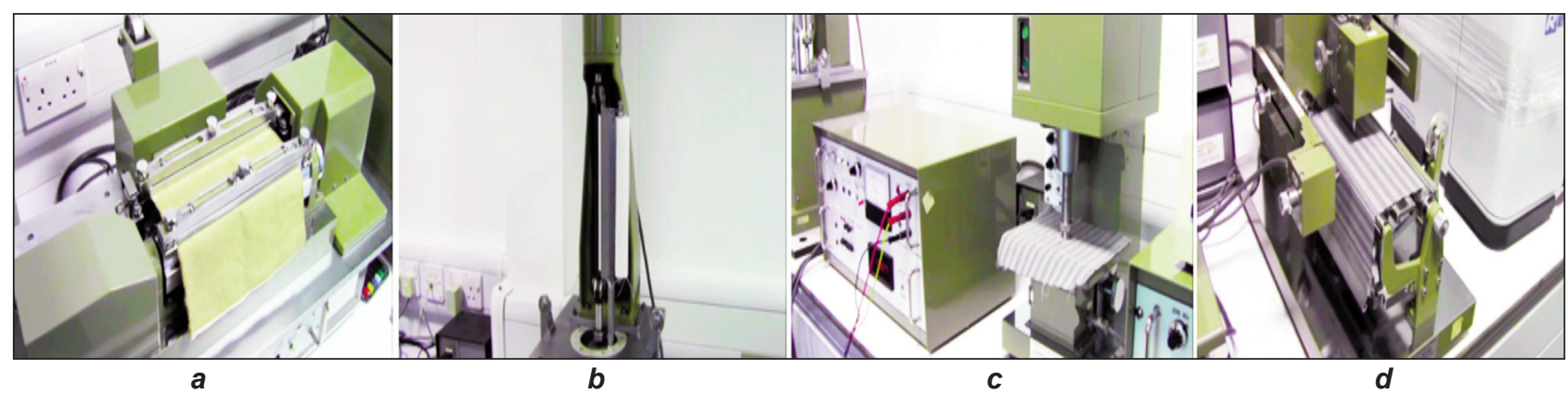

Fig. 3. Kawabata four modules KES-FB1, KES-FB2, KES-FB3 and KES-FB4

Table 3

\begin{tabular}{|l|l|l|}
\hline \multicolumn{2}{|c|}{ Hand } & \multicolumn{1}{c}{ Definition } \\
\cline { 1 - 2 } Joshi & \multicolumn{1}{|c|}{ English } & \\
\hline Numeri & Stiffness & $\begin{array}{l}\text { A feeling interconnected for the most part to the bending property. Springy } \\
\text { behavior stimulates this sensation of touching. The high density fabrics } \\
\text { constructed with elastic yarn generally own this property intensively. }\end{array}$ \\
\hline Fukurami & Fullness and softness & $\begin{array}{l}\text { Aggregation of flexible, soft and smooth feelings. Cashmere fabric exhibits } \\
\text { higher value of such feelings. }\end{array}$ \\
springy feature in fabric thickness and compression.
\end{tabular}

such targets as general fabric, cloth, paper, nonwoven fabric, and film. Bending numerical data is effective to assess the softness, stiffness and fullness, anti-drape stiffness.

KES-FB3 Compression Tester; this module behaves like pushing with a finger as seen in figure $3, c$. Compression numerical values are applicable to estimate the smoothness, fullness and softness, antidrape stiffness. KES-FB4 Surface Tester, this module responds to replicate the surface of human finger to fabric properties as shown in figure 3,d. Surface roughness and friction statistics are valuable to regulate crispness, softness and fullness, smoothness.

\section{Results and discussions}

Each property of the Kawabata evaluation system is elaborated for the sample 1 and sample 2. Polyester/ cotton (50:50) and Polyester/viscose (50:50) fabric were taken as reference for the comparison. Definitions of primary hand values are shown in table 3 [14].

\section{Tensile properties}

Table 4 portraying tensile characteristics (Extensibility, EM; linearity of load extension curve, LT; tensile energy, WT and tensile resilience, TR) of fabric samples. All mentioned tensile properties of fabric defined the level of clothing performance and utility comfort. Hand feel characteristic is basic parameter to assess the quality of fabric for common consumer so in our case the extensibility results are best than results measured in other studies [16].

Table 4 shows that Sample 02 exhibit higher (exceeds 88\%) EM value (mean=11.15) than sample 01, EM (mean=5.89). Load Elongation curve (LT) represents the extensibility of the fabric structure and Load-Elongation curve. Table 4 depicts that Sample 02 has less LT value than sample 01 which is inverse relation to extensibility trend and represents sample 02 is more comfort bale than sample 01. As mentioned by researcher that lower the LT value, higher the fabric elasticity results in higher clothing comfort [17]. Tensile energy (WT) defined as the area beneath load elongation curve [15]. Higher value of WT, represent higher fabric strength but adversely affect the hand feel. Table 4 shows that WT of sample 02 (mean=2.5) is almost 2.5 times higher than the sample 01 (9.27) that is due to greater a real density $\left(\mathrm{g} / \mathrm{m}^{2}\right)$. The same results are shown in figure 4 for

Table 4

\begin{tabular}{|l|c|c|c|c|c|c|}
\hline \multirow{2}{*}{ Parameter } & \multicolumn{3}{|c|}{ Sample 1 } & \multicolumn{3}{c|}{ Sample 2 } \\
\cline { 2 - 7 } & Wale & Coarse & Mean & Wale & Coarse & Mean \\
\hline EM [\%] & 7.59 & 4.20 & 5.89 & 14.43 & 7.87 & 11.15 \\
\hline LT [-] & 0.786 & 0.789 & 0.788 & 0.752 & 0.607 & 0.680 \\
\hline WT [g.cm/cm $\left.{ }^{2}\right]$ & 12.37 & 9.27 & 10.82 & 32.17 & 19.53 & 25.85 \\
\hline RT [\%] & 31.58 & 52.84 & 41.96 & 19.62 & 50.15 & 34.89 \\
\hline
\end{tabular}




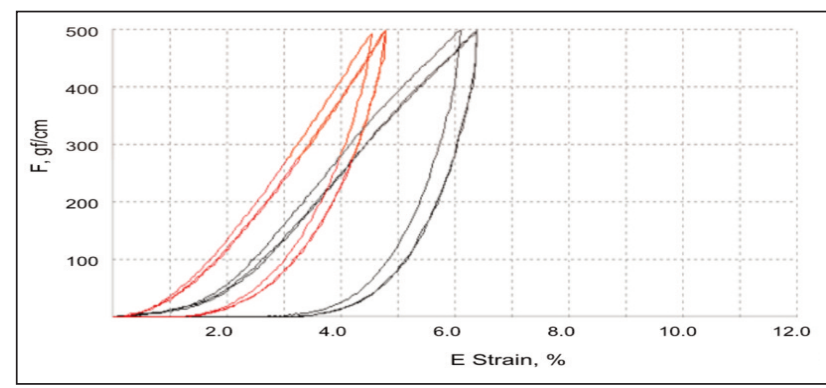

a

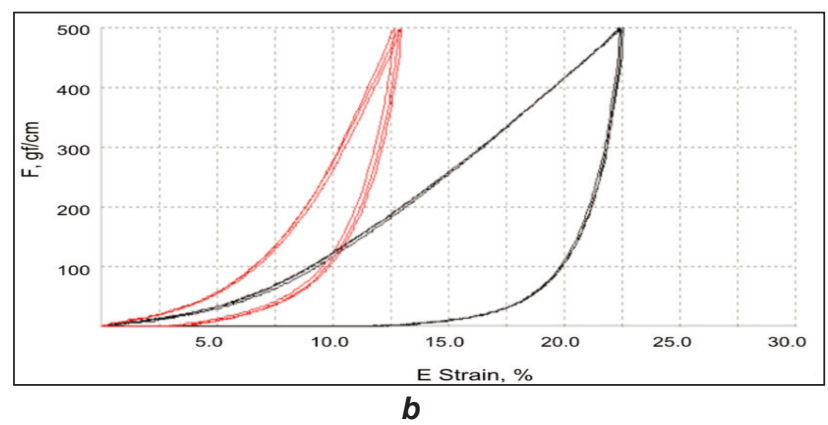

Fig. 4. The load-elongation hysteresis, red curve represents wales direction and black curve courses direction for sample $1(a)$ and sample $2(b)$ wales and courses of fabric. Both the samples (sample 01 and sample 02) tensile strains were compared with already done studies. Both these samples exhibit higher values of tensile strain (EM) and tensile energy (WT) are greater than polyester/viscose blended suiting fabric and polyester/cotton blended fabric, portray our samples are best in comfort properties [18-19]. Linearity of tensile (LT) property of nano-filament polyester fabric is almost same as of polyester/ viscose fabric and less than polyester/cotton fabric [18-19]. In case of tensile resilience (RT), the average values are lacking with better handle than $P / V$ and $\mathrm{P} / \mathrm{C}$ for both nano-filament fabrics [18-19].

\section{Shear properties}

Fabric shear property is described by shear rigidity (G) measured at $0.5^{\circ}$ and $5^{\circ}$ shear angle hysteresis of shear force as shown in table 5 .

Fabric samples are subjected to deform by an extensive range to assess their shear behavior. This method is of great importance used to quantify handling, pliability and drape-ability of fabrics, so shearing hysteresis explains the friction force between the cross-over point of wales and courses during the shrinkage or stretch. Concerning handling, less value of shearing is favorable [20-21]. Similarly, lower $2 \mathrm{HG}$ and 2 HG5 values for hysteresis are also preferred. However, shear hysteresis loop relates that the fabric deformation cannot be retrieve to its original shape. Table 5 and figure 5 show that sample 02 exhibit excellent shearing behavior than sample 01. Various studies exist in which different types of materials have been chosen to evaluate their mechanical interaction to skin. Only, shear properties of P/V with different possible blend ratio are found to be better than nano-filament fabrics [18]. Although, Sample 1 and Sample 2 exhibited good shearing rigidity and shearing force hysterics than P/C studied by Bartkowiak et al. [19].

Table 5

\begin{tabular}{|l|c|c|c|c|c|c|}
\hline \multirow{2}{*}{ Parameter } & \multicolumn{3}{|c|}{ Sample 1 } & \multicolumn{3}{c|}{ Sample 2 } \\
\cline { 2 - 7 } & Wale & Coarse & Mean & Wale & Coarse & Mean \\
\hline G [g/cm.deg] & 3.88 & 3.94 & 3.91 & 2.25 & 2.09 & 2.17 \\
\hline 2HG [g/cm] & 7.39 & 6.84 & 7.11 & 6.75 & 4.77 & 5.76 \\
\hline $2 \mathrm{HG}[\mathrm{g} / \mathrm{cm}]$ & 5.85 & 8.33 & 7.09 & 5.48 & 6.17 & 5.82 \\
\hline
\end{tabular}

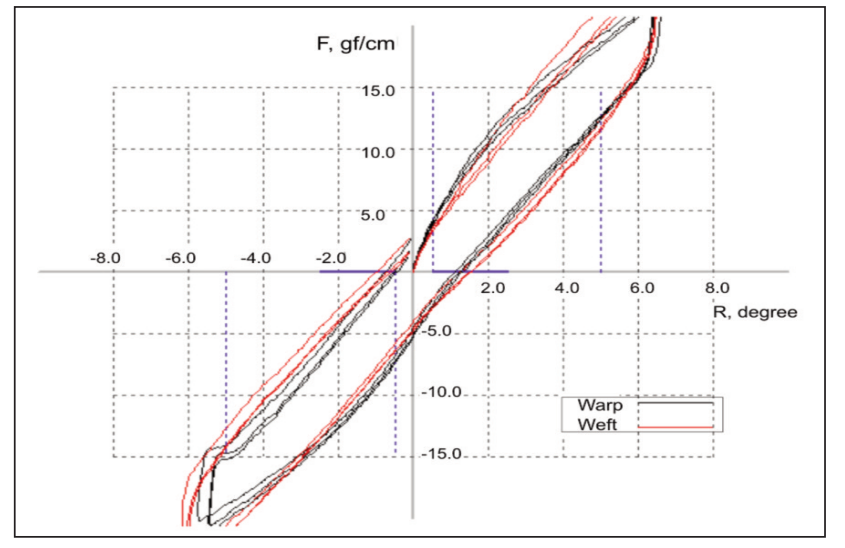

a

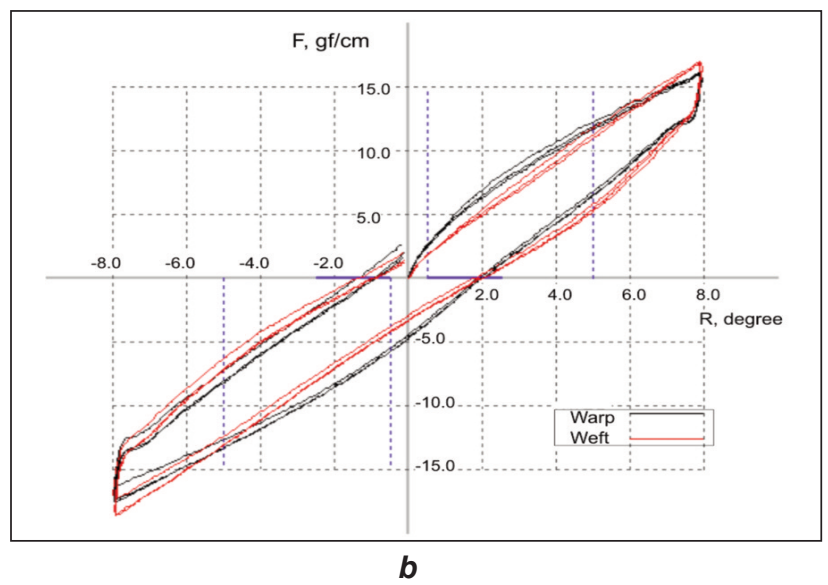

$\boldsymbol{b}$

Fig. 5. The shear stress-strain hysteresis sample 1 and sample 2. Red curve represents wales direction and black curve courses direction 


\begin{tabular}{|l|c|c|c|c|c|c|}
\hline \multirow{2}{*}{ Parameter } & \multicolumn{3}{|c|}{ Sample 1 } & \multicolumn{3}{c|}{ Sample 2 } \\
\cline { 2 - 7 } & Wale & Coarse & Mean & Wale & Coarse & Mean \\
\hline B $\left[\mathrm{g} \cdot \mathrm{cm}^{2} / \mathrm{cm}\right]$ & 0.036 & 0.048 & 0.042 & 0.029 & 0.067 & 0.048 \\
\hline 2HG $[\mathrm{g} . \mathrm{cm} / \mathrm{cm}]$ & 0.0413 & 0.0412 & 0.0412 & 0.0401 & 0.0893 & 0.0647 \\
\hline
\end{tabular}
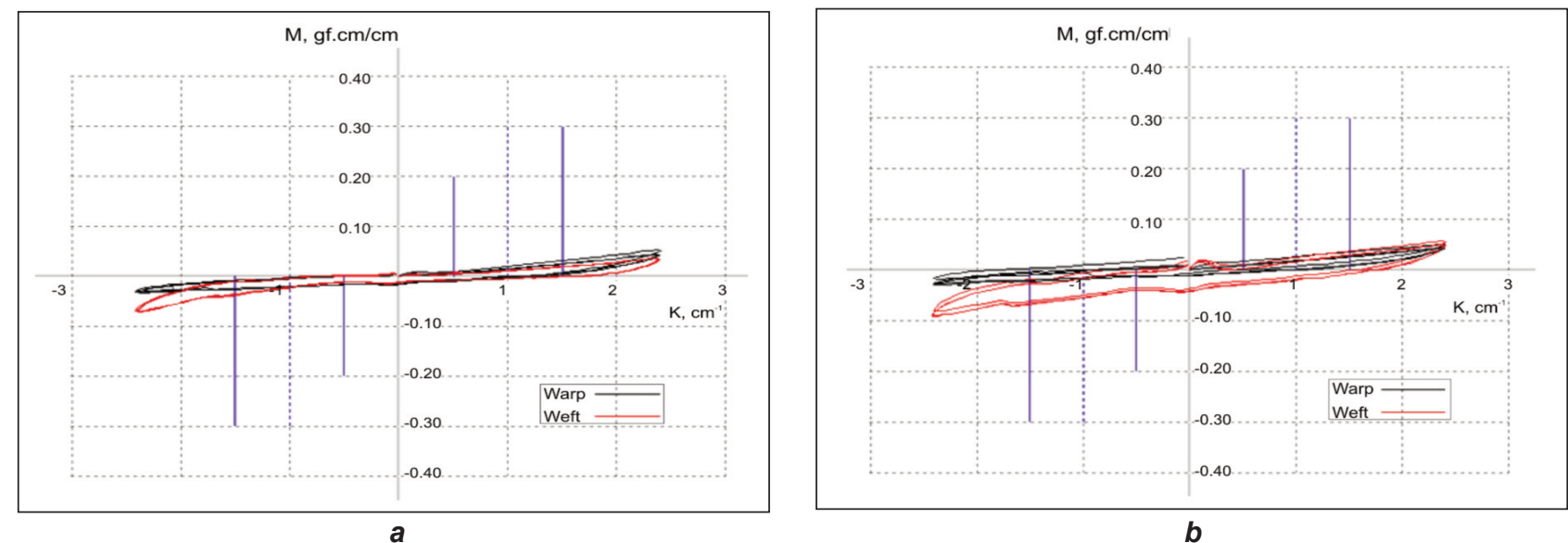

Fig. 6.The bending hysteresis for sample 1 and 2 in $(a)$ and $(b)$ respectively. Red curve represents wales direction and black curve courses direction

\section{Bending properties}

$B$ (bending rigidity) value defines that how smoothly the fabric is being bent. Bending rigidity directly influences the fabric handle. Less $B$ value means better fabric handle [22]. Table 6 and figure 6 show bending rigidity $(\mathrm{B})$ and bending hysteresis $(2 \mathrm{HB})$ results of sample 01 and sample 02. Bending hysteresis (2HB) is the ability of the fabric to be recovered. Bending moment required to produce a given curvature which depends upon a number of yarns being bent in fabric and bending rigidity of those yarns. Likewise bending rigidity value, bending hysteresis should be lower results in more fabric elasticity [17]. The values of bending rigidity $(\mathrm{B})$ and bending hysteresis (2HB) are somehow less than polyester/ viscose blended suiting fabric and significantly less than polyester/cotton blended fabric which showed its better fabric handle [18-19].

\section{Compression properties}

Compression properties include 'Linearity of thickness/compression' (LC), compression energy (WC) and compressional resilience (RC) parameters were developed in KES system. This property in Japanese terminology named as FUKURAMI means primary hand feels. Compression energy (WC) defined the bulkiness. Higher values of WC represent higher fabric compressibility [17]. Fabric thickness can affect WC. Compressional resilience ( $R C$ ) value appraises the fabric spongy behavior. Actually RC is termed as the ability of fabric to be returned after compressional deformation. Values of all the mentioned parameters are given and shown in table 7 and figure 7 .

Both samples (sample 01 and sample 02) were compared with already measured KES values of some other blends. For this we compared these two samples
Table 7

\begin{tabular}{|l|c|c|}
\hline \multicolumn{1}{|c|}{ Parameter } & Sample 1 & Sample 2 \\
\hline LC [-] & 0.329 & 0.325 \\
\hline WC [g.cm/cm $\left.{ }^{2}\right]$ & 0.161 & 0.198 \\
\hline RC [\%] & 35.78 & 35.15 \\
\hline
\end{tabular}

with polyester/viscose blended suiting fabric, the values of compression property LC (linearity of thickness/compression) and WC (compression energy) of nano-filament fabric are non-significantly greater than PV blended fabric. However; RC (compressional resilience) of PV fabric and PC fabric is almost doubled than nano-filament fabric samples [18-19].

\section{Surface properties}

The utmost objective evaluation of comfort in fabrics and materials is carried out by the utilization of surface characteristics. KES system was proposed to narrate the surface properties by the framework of MIU (Coefficient of friction), MMD (Mean Deviation) and SMD (geometrical roughness). Numeri (smoothness) describes this feature in terms of surface property. Study reveals that greater value of confidence of friction characterized in coarse direction rather than wale direction. MMD is also evaluated like MIU. The main cause is the less density of coarse yarns in fabric structure as represented in figure 8. The MIU value ranges $0-1$ and its approaching value of 1 is interpreted as increasing friction and decreasing smoothness [23]. Frictional coefficient is defined as:

$$
M I U=\frac{F}{P}
$$

Where $F$ is frictional force (in N) and $P$ - sensor load (in N). 


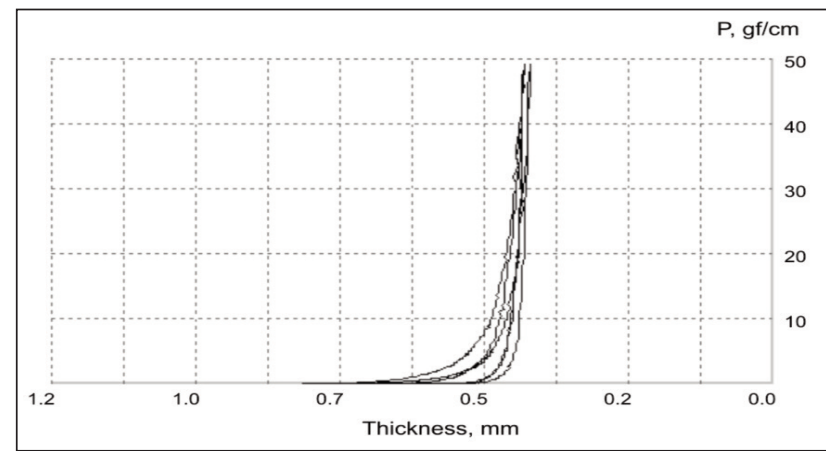

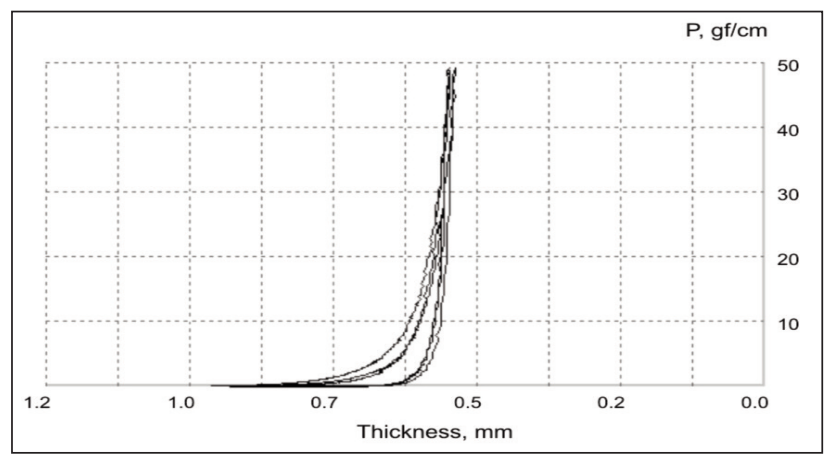

b

Fig. 7. The compression curve for sample 1 and sample 2 in (a) and (b) respectively

Results of geometrical surface roughness (SMD) were carried out to predict the level of significance due to presence of moisture. The SMD values range $0-20$ and as its approaching value of 20 is explained as the increase in the surface roughness and surface irregularities [22]. As comparing with polyester/cotton (50:50) blended fabric the values of MIU (Coefficient of friction), MMD (Mean Deviation) and SMD (geometrical roughness) are $0.154,0.0097$ and 1.60 respectively (table 8). Similarly MIU, MMD and SMD for polyester/viscose fabric showed the $0.195,0.0634$ and 6.83 average value respectively [18-19].

\section{Primary hand values of fabric}

Human response for fabric sensation termed as fabric handle that relates with physical, physiological, perceptional and social factors. These aesthetics property named as appearance and handle are primarily identified by the senses. For the evaluation of fabric as primary hand expressions, used Japanese terms are KOSHI (stiffness), NUMERI (smoothness), and FUKURAMI (softness and fullness). According to Kawabata's hand evaluation and standardization committee, koshi was more important than fukurami in the judgment [23]. High value of THV means lower koshi (stiffness) but higher numeri (smoothness) and fukurami (fullness). High stiffness is problematic for wearer during workout [26].

The resistance to bending, i.e. fabric stiffness, and the fabric weight are major components affecting the method in which a fabric drapes or hangs. The ratio between "fabric resistances to bending" to "weight" is a quantitative estimate of the way the fabric hangs [25]. Bending properties of fabric compared with Koshi. Both nano-filament fabric samples (Sample 01 and sample 02) attribute bending rigidity value is similar to Poly/Viscose blended fabricbut $180 \%$ higher than Poly/Cotton blended fabric [18-19].

Table 8

\begin{tabular}{|l|c|c|c|c|c|c|}
\hline \multirow{2}{*}{ Parameter } & \multicolumn{3}{|c|}{ Sample 1 } & \multicolumn{3}{c|}{ Sample 2 } \\
\cline { 2 - 7 } & Wale & Coarse & Mean & Wale & Coarse & Mean \\
\hline MIU $[-]$ & 0.280 & 0.292 & 0.286 & 0.240 & 0.272 & 0.256 \\
\hline MMD $[-]$ & 0.0108 & 0.0204 & 0.0156 & 0.0107 & 0.0116 & 0.0111 \\
\hline SMD $[\mu \mathrm{m}]$ & 1.25 & 3.43 & 2.34 & 1.46 & 2.54 & 2.00 \\
\hline
\end{tabular}

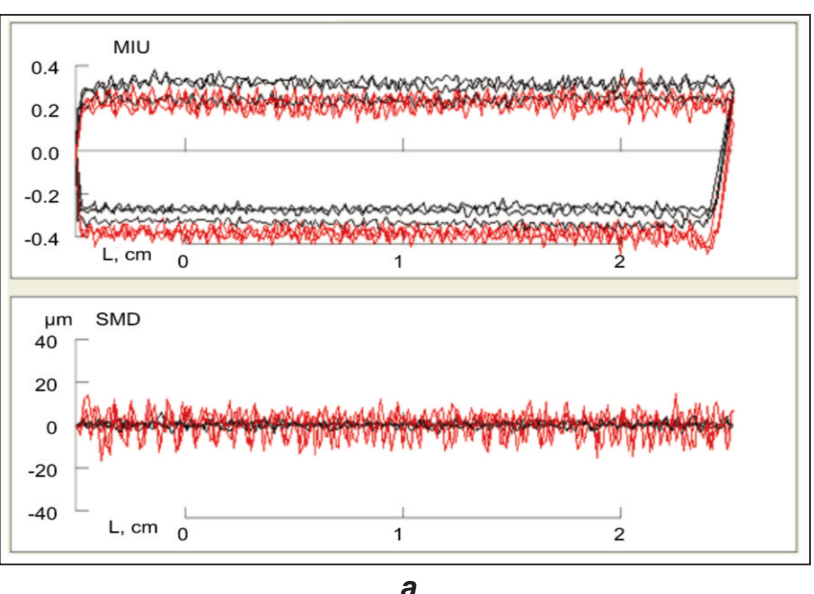

a

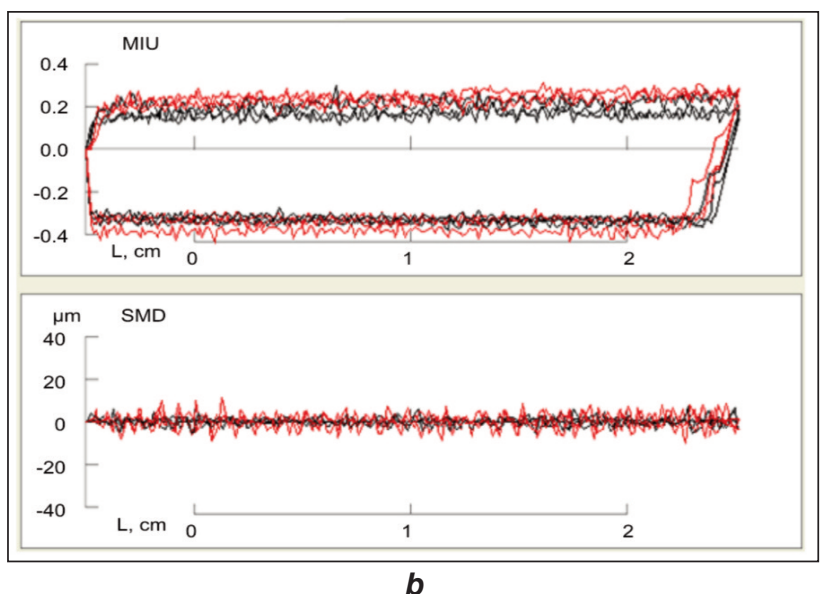

b

Fig. 8. Surface behavior for sample 1 and sample 2. Red curve represents wales direction and black curve courses direction 
Table 9

\begin{tabular}{|l|c|c|c|c|}
\hline Fabric hand value & Sample 1 & Sample 2 & PC & PV \\
\hline Koshi & 3.58 & 2.5 & 6.14 & 4.23 \\
\hline Numeri & 4.21 & 6.91 & 5.71 & 5.77 \\
\hline Fukurami & 4.35 & 6.84 & 4.08 & 4.24 \\
\hline THV & 2.51 & 2.82 & 3.46 & 3.28 \\
\hline
\end{tabular}

As far the basic sensorial comfort is concern, numeri (smoothness) is also a prime factor in the fabric handle characteristics. A fabric that provides little frictional resistance to motion across its surface and owns a low coefficient of friction is presumably called a smooth fabric [25]. Surface property is mainly responsible to describe the Numeri. Sample 1 appeared with less Numeri than sample 02 which may be attributed to the compressional and tensile energies, bending rigidity and hysteresis of shear curve. As comparison with polyester/viscose suiting fabric the Numeri values were high with the increase of polyester content in blend. Likewise the P/C (85:15) blended fabric reported with high Numeri reading [18-19].

Fullness and softness: A springy property in thickness and compression accompanied by a warm feeling is contiguous to this (fukurami means swelling). Fukurami (fullness and softness) is negatively correlated to the summer total hand value [24]. Fullness implicit body and fabric thickness, yields soft surface due to the density of the protruding fibers. Indistinguishable to the Numeri the fullness of sample 2 is higher than sample 1 . This may be imputed to lower compressional resilience and high shear force (table 9). Samples 1 revealed the same results as of polyester/viscoseand polyester/cotton (50:50) blended fabric concerning fullness [18-19].

THV (total hand value) of both samples were considered from primary hand values by KES-system. From the table it was determined that higher values are due to more polyester content in gram per square meter and dense structure. THV of P/C blended fabric and P/V (50:50) blended fabric reported 2.46 almost the same of sample 1 (figure 9).

\section{CONCLUSIONS}

Nano-filament fabrics gave good drapability than normal filament fabric. Nano-filament fabrics also contributed preferable hand values. On average, the total hand values of Nano-filament fabric were equivalent or slightly superior to suiting fabric [18-19]. Nano-filament Polyester fibers have much more absorbent and transport behavior than spun polyester, so the moisture is easily drained from the skin surface and provide the comfort feeling.

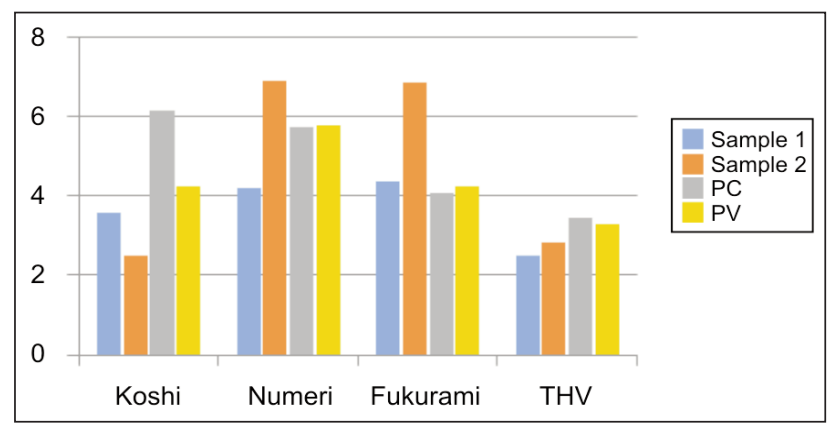

Fig. 9. Total hand value of fabric samples

1. Higher the value of EM and RT better the comfort and fabric handle respectively. Less value of LT gives high elasticity. More WT led to strong tensile but it adversely affect the hand feel. Sample 1 tensile properties were appreciated than sample 2 .

2. The shear rigidly and hysteresis of shear rigidly increased with the gram per square meter of sample 2 as compared to sample 1 . However, less value of shear rigidly is preferable concerning handling.

3. Bending rigidity value defines that how smoothly the fabric is being bent. Less $B$ value means better fabric handle. Both samples graphical represented with same bending rigidity.

4. Compression properties are resemble with FUKURAMI (primary hand feel) of fabric. LC and RC values for both samples are similar due to the same ability of fabric to be returned after compressional deformation.

5. Numeri (smoothness) describes the same feature in terms of surface property. Study reveals that greater value of coefficient of friction (MIU) characterized in lower geometry roughness. MMD is also evaluated like MIU. So sample 1 analyzed as high value of MIU than sample 2 .

6. Koshi was more important than fukurami in the judgment. High value of TVS means lower koshi (stiffness) but higher numeri (smoothness) and fukurami (fullness). High stiffness is problematic for wearer during workout. Sample 1 found good than the sample 2 in this regard.

Industrial point of view: this research is useful for such suiting where comfort and transportation properties are correlated to each other like glove industry. It will also be useful to know about the thickness and GSM requirement for the manufacturer. Nowadays, it is only buyer's market and this study could be deciding factor.

\section{Acknowledgments}

The authors would like to thank the Technical University of Liberec (TUL) for Student Grant (SGS 21200) 2017.

\section{BIBLIOGRAPHY}

[1] Pamuk, O. Clothing comfort properties in textile industry. In: Natural and Applied Sciences, 2008, vol. 3, issue 1.

[2] Mäkinen, M., Meinander, H., Luible, C., Magnenat-Thalmann, N. Influence of physical parameters on fabric hand. Proceedings of the HAPTEX'05 Workshopon Haptic and Tactile Perception of Deformable Objects. Hanover, December, 2005. 
[3] Sajjadi, A., Sheikhzadeh, M., Rikhtehgaran, R., Hajrasouliha, J. Prediction of fabric handle value using ordinal regression model. In: The Journal of the Textile Institute, 2015, vol. 106 issue 1, pp. 1161-1172.

[4] Makinen, M., Meinander, H., Luible, C. Influence of physical parameters on fabric hand. Proceedings of the HAPTEX'05 Workshopon Haptic and Tactile Perception of Deformable Objects (Hanover), 2015, vol. 9.

[5] Unal, P.G., Ureyen, M.E. Mechanical and permeability properties of sportech fabrics.In: Industria Textila, 2016, vol. 67, no. 3, pp. 151-156.

[6] Yick, K., Cheng, K.P.S., Dhingra, R.C., How, Y.L. Comparison of mechanical properties of shirting materials measured on the kes- $f$ and fast instruments. In: Textile Research Journal, 1996, vol. 66, issue 10, pp. 622-633.

[7] Behera, B.K., Mishra, R.K., Singh, T.G., Sehgal, P. Comfort and handle behaviour of linen and linen blended fabrics. In: Textile Asia, 2007, vol. 38, no. 3.

[8] El Messiry, M., El Ouffy, A., Issa, M. Microcellulose particles for surface modification to enhance moisture management properties of polyester, and polyester/cotton blend fabrics. In: Alexandria Engineering Journal, 2015, vol. 54, issue 2, pp. 127-140.

[9] Sampath, M.B., Mani, S., Nalankilli, G. Effect of filament fineness on comfort characteristics of moisture management finished Polyester knitted fabrics. In: Journal of Industrial Textiles, 2011, vol. 41, issue 2, pp. 160-173.

[10] Yip, J., Ng, S-P. Study of three-dimensional spacer fabrics: physical and mechanical properties. In: Journal of Materials Processing Technology, 2008, vol. 206, issue 1, pp. 359-364.

[11] Park, S.W., Hwang, Y.G. Comparison of Total Hand of Single Knitted Fabrics Made from lincLITE® and Conventional Wool Yarns. In: Textile Research Journal, 2002, vol. 72, issue 10, pp. 924-930.

[12] Chronakis, I.S. Micro-/nano-fibers by electrospinning technology: processing, properties and applications. Micromanufacturing Engineering and Technology. Boston, In: Elsevier, 2010, pp. 264-286.

[13] Wakeham, H., Spicer, N. Pore-size distribution in textiles-a study of windproof and water-resistant cotton fabrics. In: Textile Research Journal, 1949, vol. 19, pp. 705-710.

[14] Harwood, R.J., Weedall, P.J., Carr, C. The use of the Kawabata Evaluation System for product development and quality control. In: Coloration Technology, 1990, vol. 106, issue 2, pp. 64-68.

[15] Kawabata, S. The standardization and analysis of hand evaluation. 2nd edition. In: Textile Machinery Society of Japan (Osaka), 1980.

[16] Kawabata, S., Niwa, M. Objective measurement of fabric mechanical property and quality: Its application to textile and clothing manufacturing. In: International Journal of Clothing Science and Technology, 1991, vol. 3 issue 1, pp. 7-18.

[17] Behera, B.K., Hari, P.K. Woven textile structure: Theory and applications. In: Elsevier, 2010.

[18] Nayak, R.K., Punj, S.K., Chatterjee, K.N. Comfort properties of suiting fabrics. In: Indian Journal of Fibre and Textile Research, 2009, vol. 34, pp. 122-128.

[19] Bartkowiak, G., Frydrych, I., Komisarczyk, A., Greszta, A. Fabric selection for the reference clothing destined for ergonomics test of protective clothing - sensorial comfort point of view. In: AUTEX Research Journal, 2016, vol. 16, issue 4, pp. 256-261.

[20] Hu, J. Structure and Mechanics of Woven Fabrics, In: Elsevier, 2004

[21] Kawabata, S., Niwa, M., Kawai, H. The finite deformation of plain weave fabrics part III, The shear deformation theory. In: The Journal of the textile institute, 1973, vol. 64, issue 1, pp. 62-85.

[22] Yazdi, A., Shahbazi, Z. Evaluation of the bending properties of viscose/polyester woven fabrics. In: Fibres \& Textiles in Eastern Europe, 2006, vol. 14, pp. 50-54.

[23] Nawaz, N., Troynikov, O., Watsonc, C. Evaluation of surface characteristics of fabrics suitable for skin layer of firefighters' protective clothing. In: Physics Procedia, 2011, vol. 22, pp. 478-486.

[24] Sun, M.N. A new tester and method for measuring fabric stiffness and drape. In: Textile Research Journal, 2008, vol. 78 , issue 9 , pp. 761-770.

[25] Mondal, S., Reddy, V., Sarkar, A., Aravindakshan, P., Ghatak, A. Effect of surface modification on frictional properties of polyester fabric. In: Tribology International, 2016, vol. 97, pp. 38-48.

[26] Ajayi, J.O. Fabric smoothness, friction, and handle. In: Textile Research Journal, 1992, vol. 62, issue 1, pp. 52-59.

\section{Authors:}

\section{MUSADDAQ AZEEM MSc. ${ }^{1}$}

Eng. AMAL BOUGHATTAS ${ }^{2}$

Eng. HAFIZ FAISAL SIDDIQUE MSc. ${ }^{1}$

doc. Eng. ANTONIN HAVELKA CSc. ${ }^{1}$

Eng. SAJID HUSSAIN MSc. ${ }^{1}$

${ }^{1}$ Technical University of Liberec, Faculty of Textile Engineering

Studentska 1402/2, 461 17, Liberec 1, Czech Republic.

${ }^{2}$ Monastir University, National School of Engineers, Department of Textile Engineering

Avenue Ibn Eljazzar-5019 Monastir-TUNISIA

\section{Corresponding author:}

\section{MUSADDAQ AZEEM}

e-mail: musaddaq.azeem@tul.cz 


\title{
A comparative analysis of air-jet yarn properties with the properties of ring spun yarns
}

\author{
DOI: 10.35530/IT.069.01.1419
}

HÜSEYIN GAZI TÜRKSOY

DENIZ VURUŞKAN

TUĞBA AKKAYA

SÜMEYYE ÜSTÜNTAĞ

REZUMAT - ABSTRACT

\section{Analiză comparativă între proprietățile firelor filate cu jet de aer și proprietățile firelor filate cu inele}

Filarea cu inele este cea mai obișnuită metodă utilizată dintre metodele de filare a fibrelor scurte. Din cauza limitărilor vitezei de producție a filării cu inele, noile metode de filare devin din ce în ce mai populare. Dintre noile metode de filare, sistemele de filare cu jet de aer au atras atenția prin cota lor de piață. În acest studiu, proprietățile firelor filate cu jet de aer au fost analizate comparativ cu proprietătile firelor filate cu inele echivalente, atât pentru firele unice, cât și pentru cele cu fire răsucite. S-a constatat că firele filate cu jet de aer pe mașinile de filat Rieter și Murata nu prezintă diferențe semnificative în ceea ce privește proprietățile fizice. Datorită structuriilor speciale, firele filate cu jet de aer prezintă valori mai mici ale pilozității și ale tenacității în comparație cu firele filate cu inele, echivalente.

Cuvinte-cheie: fir filat cu jet de aer, mașină de filat Murata Vortex, filare cu jet de aer Rieter, fir filat cu inele, proprietățile firului

\section{A comparative analysis of air-jet yarn properties with the properties of ring spun yarns}

Ring spinning is the most common method used among the short staple fibers spinning methods. Due to limitations of the production speed in the ring spinning, new spinning methods become more popular with each passing day. Air-jet spinning systems gathered attention with their market share in the new spinning methods. In this study, the properties of the air-jet yarns were comparatively analyzed with the properties of the equivalent Ring yarns, for both single and ply-twisted forms. It was found that the Rieter and Murata air-jet yarns do not show significant differences in terms of physical properties of yarns. Due to their special structure, air-jet yarns show lower hairiness and tenacity values when compared to the equivalent Ring yarns.

Keywords: air-jet yarn, Murata Vortex Spinner, Rieter air-jet spinning, Ring yarn, yarn properties

\section{INTRODUCTION}

The textile industry is under a continuous and unplanned obligation to meet the diverse array of customer demands. This obligation inevitably finds its reflections, which require the yarn industry to produce diverse, novel and creative yarns with high production speed. Consequently, new spinning techniques such as open-end rotor, open-end friction, air-jet have been introduced into the textile market, which offer improved properties, quality and/or reduced costs for yarn production. Among them, air-jet spinning system has obvious advantages like very high spinning and delivery speed [1-2].

Air-jet spinning technology was firstly introduced by DuPont in 1956, though at that time it was not commercially successful for $100 \%$ short staple spinning. By this system, the so-called fascinated yarns are produced, having outside binding fibers wrapped around a core of parallel fibers. Fascinated yarn production system is based on false twist principle, where the twist is imparted pneumatically in air-jet spinning [3-6].

Murata Machinery Ltd. from Japan has developed the most commercially successful air-jet spinning machines to date and continues to dominate globally the air-jet spinning technology. The company introduced its first air-jet spinning machine, Murata Jet
Spinner, MJS 801, in 1982. The machine contains a three-roll drafting system and is equipped with two air-jet nozzles that create air vortices rotating in opposite directions. The system had some restriction on producing yarns of $100 \%$ cotton or rich blends of cotton fibers [7].

Subsequently, Murata has modified its air-jet spinning system. The latest concept in air-jet spinning developed by Murata Machinery Ltd. is known as the MVS - Murata Vortex Spinner, in 1997. Rieter Machine Works Ltd. has introduced similar air-jet spinning machine at the 2009 International Textile Machinery Exhibition in Istanbul [7-8].

These two systems use a modified single air nozzle which resulted in higher number of wrapping fibers when compared with the previous air-jet spinning systems. In both systems, the fiber bundles are firstly fed to a four-line drafting unit, and then the drafted fiber bundles are passed through the modified spinning nozzle and hallow spindle to make them into a strand of yarn. The air stream in spinning nozzle focuses the leading ends of the fiber bundles at the yarn center and directs the trailing ends to form the outer layer that wraps the yarn. This action results in a fascinated yarn structure that consists of a core of parallel fibers held together by wrapper fibers. The formed yarn passes through the yarn cleaner, where 
defects are removed, and is wound on a package [3, 6-7, 9-10].

Even though both MVS and Rieter air-jet spinning (RAJ) machines are based on a similar principle; the air-jet nozzles used in Murata and Rieter are different in design and construction. Due to the air stream in spinning nozzle, a certain torque is generated in the yarn being formed. This torque has the tendency to propagate to the front roller of drafting unit. This kind of the twist propagation must be avoided to prevent interferences with the generation of the necessary free fiber ends. Therefore, the two companies adopted two different solutions, where Murata used a needle in the nozzle block, as illustrated in figure 1,a, and Rieter used a special curved path of the fibers at the nozzle tip with an arc shape, as shown in figure $1, b$. Occurring a bending action at the tip of the needle (for MVS) and curved path (for RAJ) prevents the twist propagation [11].

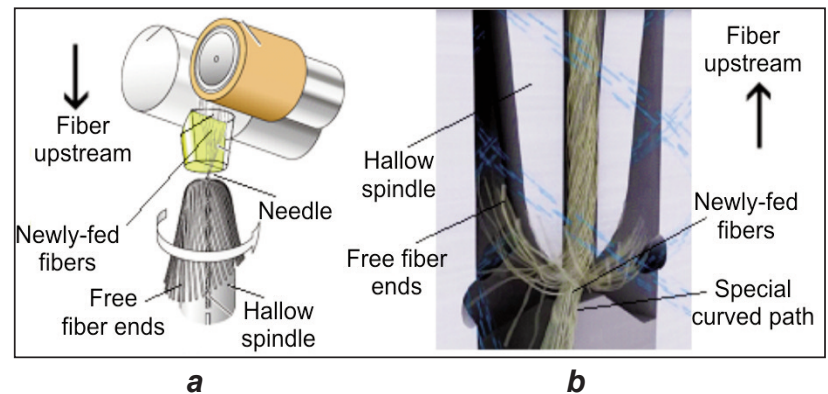

Fig. 1. Illustrations of yarn formation zones in MVS (a) and RAJ $(b)[11,15]$

The fiber upstream is another difference in the design of the two systems (figure 1). In the Murata system, the drafting system is located above the spinning nozzle and yarns are delivered at the bottom. Rieter preferred to reverse the setup and the sliver is fed from the bottom and delivered yarn is wound up at the top. By the reverse set up, Rieter provides space efficiency and also additional support for the generation of free fiber ends.

The properties of spun yarns have significant influence on the performance of subsequent manufacturing operations as well as the quality of the textile endproducts [1]. Yarn properties are mainly affected by the yarn structure, which is primarily determined by the spinning process [12-13]. In the literature, the studies related to air-jet spinning systems, especially RAJ, have been limited. In addition, the majority of the available literature constitutes of the information provided by the machine manufacturer companies [14-17]. In this paper, the properties of the MVS and RAJ yarns were comparatively analyzed with the properties of the equivalent Ring yarns both single and ply-twisted form.

\section{MATERIALS AND METHODS}

The paper analyses various properties of air-jet yarns (MVS and RAJ) compared to the equivalent Ring

\begin{tabular}{|l|c|c|c|}
\hline \multicolumn{4}{|c|}{ SPINNING PARAMETERS } \\
\hline & MVS & RAJ & Ring \\
\hline Delivery Speed (m/min) & 400 & 400 & 18.2 \\
\hline Total Draft & 160 & 160 & 30.6 \\
\hline Sliver Weight (kTex) & 3.58 & 3.58 & 0.58 \\
\hline Spindle Speed (rpm) & - & - & 16500 \\
\hline Ring Diameter (mm) & - & - & 40 \\
\hline Spindle Inner Diameter (mm) & 1.2 & 1.2 & - \\
\hline Air Pressure (MPa) & 0.55 & 0.55 & - \\
\hline
\end{tabular}

Table 2

\begin{tabular}{|c|c|c|c|c|}
\hline \multicolumn{5}{|c|}{ COUNT AND TWIST DETAILS OF YARNS } \\
\hline $\begin{array}{c}\text { Yarn } \\
\text { type }\end{array}$ & $\begin{array}{c}\text { Nominal } \\
\text { count } \\
(\mathrm{Ne})\end{array}$ & $\begin{array}{c}\text { Actual } \\
\text { count } \\
(\mathrm{Ne})\end{array}$ & $\begin{array}{c}\text { Nominal } \\
\text { twist } \\
(\mathrm{T} / \mathrm{m})\end{array}$ & $\begin{array}{c}\text { Actual } \\
\text { twist } \\
(\mathrm{T} / \mathrm{m})\end{array}$ \\
\hline \multirow{2}{*}{ MVS } & $\mathrm{Ne} 30 / 1$ & 29.50 & - & - \\
\cline { 2 - 5 } & $\mathrm{Ne} 30 / 2$ & 14.56 & 645 & 648 \\
\hline \multirow{2}{*}{ RAJ } & $\mathrm{Ne} 30 / 1$ & 29.65 & - & - \\
\cline { 2 - 5 } & $\mathrm{Ne} 30 / 2$ & 14.74 & 645 & 650 \\
\hline \multirow{2}{*}{ Ring } & $\mathrm{Ne} 30 / 1$ & 28.50 & 800 & 785 \\
\cline { 2 - 5 } & $\mathrm{Ne} 30 / 2$ & 14.54 & 645 & 642 \\
\hline
\end{tabular}

yarns. Initially, $100 \%$ viscose $\mathrm{Ne} 30 / 1$ yarns were produced with three different systems. Viscose fibers with $38 \mathrm{~mm}$ average staple length and 1.2 dtex fineness were used. Viscose fibers were processed on the traditional short staple system using standard mill procedures, adjustments and practices. The major spinning parameters and count-twist details of the yarns were summarized respectively in table 1 and table 2.

The MVS yarn was produced on the MVS 861 while the RAJ yarn was produced on the Rieter J10 machine. In order to produce ply-twisted yarn samples, some yardage of single MVS, RAJ and Ring yarns were passed to the two-for-one twisting machine (Leewha 560 SA).

All yarn samples were conditioned at least for 24 hours in an atmosphere of $20 \pm 2^{\circ} \mathrm{C}$ and $65 \pm 2 \%$ relative humidity. All tests were performed at the same conditions. Yarn tensile properties were investigated by Premier Tensomaxx 7000 testing machine. Tensile test was conducted at the specimen test length of $500 \mathrm{~mm}$ and yarn speed of $5 \mathrm{~m} / \mathrm{min}$. Yarns unevenness and hairiness tests were performed by Premier Tester 7000 with yarn speed of $400 \mathrm{~m} / \mathrm{min}$ at $2.5 \mathrm{~min}$ utes testing time. Visual comparisons of all yarn types were examined with Olympus SZ61 stereo microscope. Test results were analyzed by using one-way replicated ANOVA, and the means were compared by DUNCAN tests at 0.05 level using the SPSS 13.0 statistical package. 


\section{RESULTS AND DISCUSSION}

In this section, various physical properties of single and ply-twisted air-jet yarns were discussed comparatively with Ring counterparts. The longitudinal views of single and ply-twisted yarns were examined under the stereomicroscope as seen in figure 2. The MVS and RAJ single yarns show a structure where the strand of the input fibers is divided into two groups of relatively parallel fibers in the core and wrapping fibers at the sheath. From figure 2, it is easy to see that air-jet yarns have less hairiness when compared with Ring yarns. Moreover, air-jet yarns have much more bulk and loose structure for both single and plytwisted forms. RAJ single yarns have a more ring-like appearance as well as a higher number of wrapper fibers compared to MVS yarns.Additionally, the number of fibers of RAJ single yarns hooked in both ends is relatively higher than that of MVS yarns. It is thought that the amount of hooked fibers is affected by the yarn forming process and direction of fiber upstream.

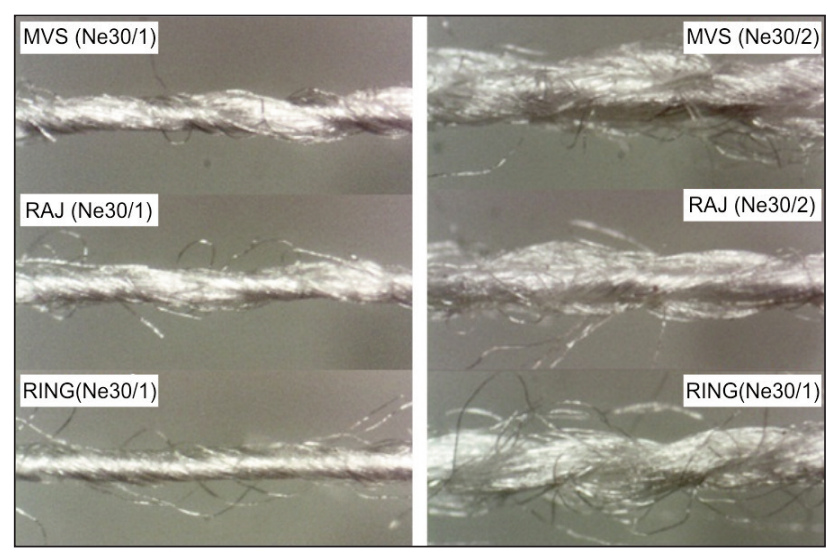

Fig. 2. Longitudinal views of MVS, RAJ and Ring yarns at the magnification of $40 x$

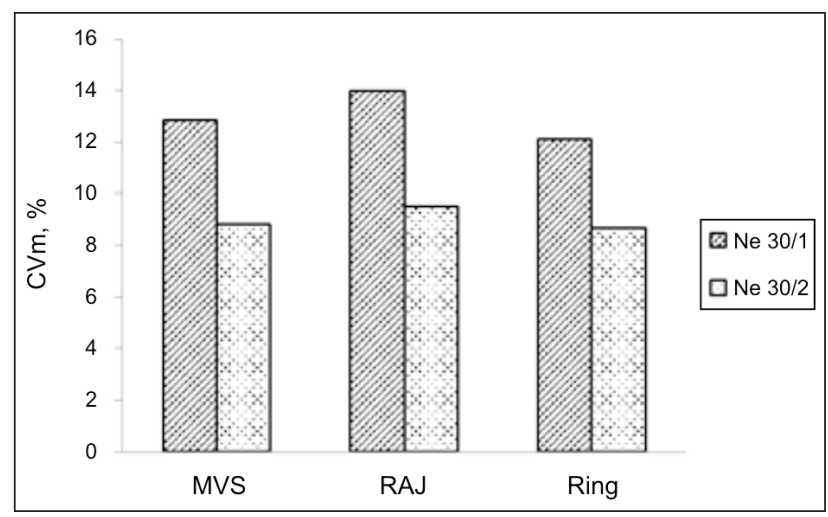

Fig. 3. Average unevenness values of yarn samples

Unevenness values of yarn samples were given in figure 3. Based on the ANOVA results, the spinning system has a significant influence on the unevenness values of yarns $\left(p_{\text {single }}=0.000, p_{\text {ply-twisted }}=0.000\right.$ ). The Duncan test results of unevenness, tenacity, breaking elongation and hairiness of yarns produced in this study were given respectively in tables 3-6.

According to Duncan test results, there are significant differences between unevenness values of all yarn samples, for both single and ply-twisted forms (table 3 ). The lowest unevenness values were obtained from the Ring yarns whereas the highest unevenness values were seen in RAJ yarns, for single and plytwisted form.

Table 3

\section{DUNCAN TEST RESULTS FOR UNEVENNESS}

\begin{tabular}{|c|c|c|c|c|c|c|}
\hline Process & \multicolumn{3}{|c|}{ Single form } & \multicolumn{3}{|c|}{ Ply-twisted form } \\
\hline Unevenness & 1 & 2 & 3 & 1 & 2 & 3 \\
\hline MVS & & 12.85 & & & 8.814 & \\
\hline RAJ & & & 13.91 & & & 9.51 \\
\hline Ring & 12.102 & & & 8.65 & & \\
\hline Sign. & 1.000 & 1.000 & 1.000 & 1.000 & 1.000 & 1.000 \\
\hline
\end{tabular}

The unevenness values of Ring yarns are better than that of air-jet yarns. In yarn production, the mechanism of twist insertion is a major factor that affects the structure and ultimately the properties of the produced yarn. The lower unevenness of Ring yarns may be a result of almost constant twist distribution in the yarn structure when compared to air-jet yarns. As expected, the unevenness values of single-ply yarns are higher than that of the ply-twisted yarns. This result reflects the positive influence of plying process on the unevenness values.

Tenacity values of yarn samples were given in figure 4. Based on the ANOVA results, the spinning system has a significant influence on the tenacity values of yarns $\left(p_{\text {single }}=0.018, p_{\text {ply-twisted }}=0.000\right)$. Duncan test results show that there isn't a significant difference between tenacity values of yarns produced by air-jet systems for both single and ply-twisted forms (table 4). It was observed that the tenacity values of air-jet yarns are lower than that of Ring counterparts. In the case of MVS yarn, Soe et al. reported that the twisted

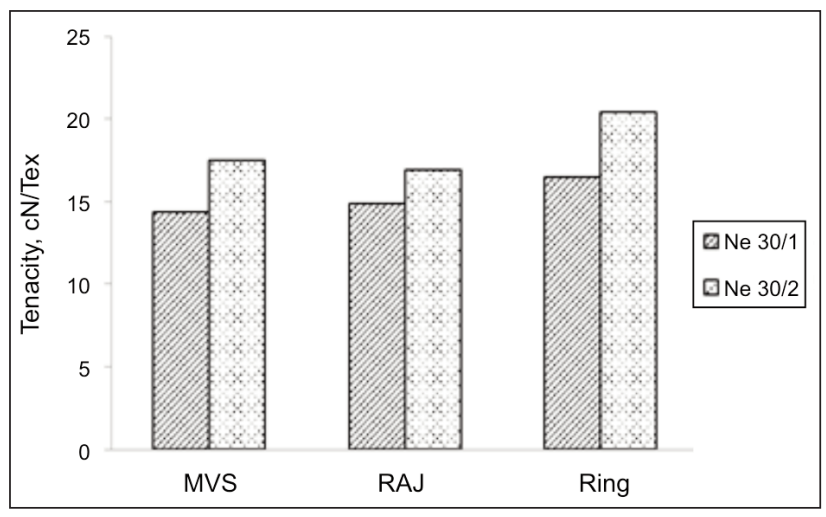

Fig. 4. Average tenacity values of yarn samples 
Table 4

DUNCAN TEST RESULTS FOR TENACITY

\begin{tabular}{|c|c|c|c|c|}
\hline Process & \multicolumn{2}{|c|}{ Single form } & \multicolumn{2}{c|}{ Ply-twisted form } \\
\hline Tenacity & 1 & 2 & 1 & 2 \\
\hline MVS & 14.37 & & 17.87 & \\
\hline RAJ & 14.86 & & 17.284 & \\
\hline Ring & & 16.48 & & 20.80 \\
\hline Sign. & 0.461 & 1.000 & 0.184 & 1.000 \\
\hline
\end{tabular}

fiber core of Ring yarn as opposed to the nontwisted core of the MVS yarn, creates a stronger bond between the fibers and these fundamental structural effects cause the higher tenacity value of Ring yarn compared with MVS yarn [18].

In addition, it was seen that the increase in the tenacity values of yarns after ply-twisting process varies according to spinning systems. The ratios of increase were founded as $23.80 \%, 22 \%$, and $14 \%$ for Ring, MVS, and RAJ yarns respectively.

Breaking elongation values of yarn samples were given in figure 5. Based on the ANOVA results, the spinning system has a significant influence on the breaking elongation values of yarns $\left(p_{\text {single }}=0.000\right.$, $p_{\text {ply-twisted }}=0.000$ ). Duncan test results show that there isn't a significant difference between breaking elongation values of air-jet yarns for both single and ply-twisted form. Conversely, the differences between breaking elongation values of air-jet and Ring yarns

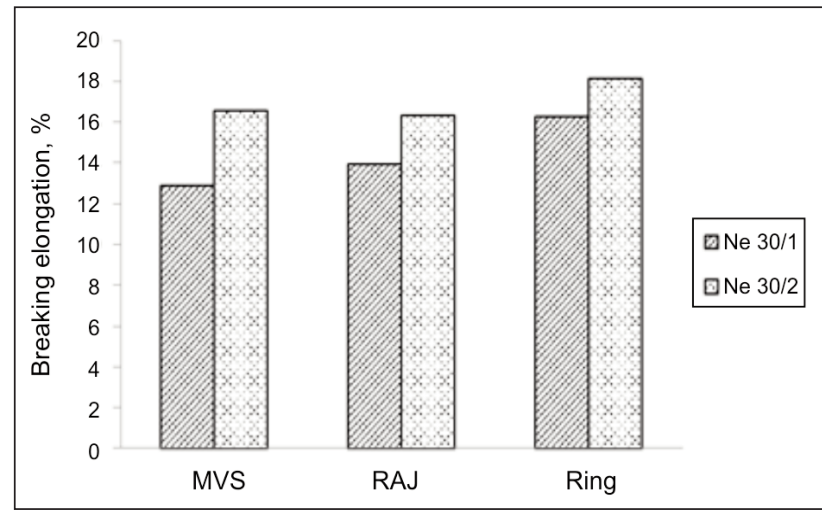

Fig. 5. Average breaking elongation values of yarn samples

Table 5

\begin{tabular}{|c|c|c|c|c|}
\hline \multicolumn{5}{|c|}{$\begin{array}{c}\text { DUNCAN TEST RESULTS FOR } \\
\text { BREAKING ELONGATION }\end{array}$} \\
\hline Process & \multicolumn{2}{|c|}{ Single form } & \multicolumn{2}{l|}{ Ply-twisted form } \\
\hline Breaking elongation & 1 & 2 & 1 & 2 \\
\hline MVS & 12.89 & & 16.558 & \\
\hline RAJ & 14.02 & & 16.30 & \\
\hline Ring & & 16.24 & & 18.11 \\
\hline Sign. & 0.076 & 1.000 & 0.212 & 1.000 \\
\hline
\end{tabular}

were found to be statistically significant for both single and ply-twisted form (table 5).

The highest breaking elongation value was obtained with Ring yarns for single and ply-twisted form. The lowest breaking elongation value was obtained with MVS yarns for single form whereas the lowest one was obtained with RAJ yarns for ply-twisted form (figure 5). As known, the breaking elongation values of single yarns increase with ply-twisting process. The maximum increase was observed in MVS yarns; conversely, the minimum increase was observed in Ring yarns.

Yarn hairiness is characterized by the amount of freely moving fiber ends or fiber loops protruding from a yarn. The hairiness properties of yarn samples were measured using Premier Tester. Premier Tester works through a light source incident on the yarn core, and the amount of light scattered by the protruding fibers is used to work out a Hairiness Index $(\mathrm{H})$ value for the yarn. The $\mathrm{H}$ value corresponds to the total length of protruding fibers in centimeters within the measurement field of $1 \mathrm{~cm}$ length of the yarn [19]. In figure 6, the average Hairiness Index values of yarn samples were shown.

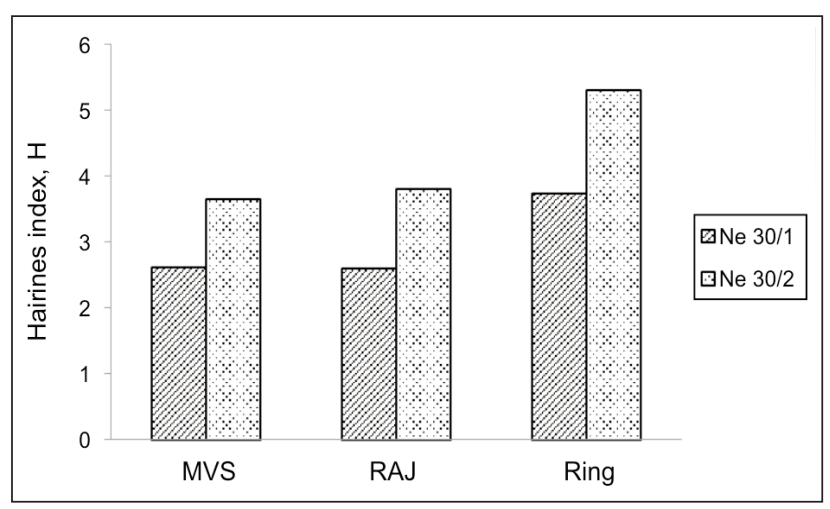

Fig. 6. Average hairiness values of yarn samples

According to ANOVA test result, the spinning system has a significant influence on the $\mathrm{H}$ values of yarns $\left(p_{\text {single }}=0.000, p_{\text {ply-twisted }}=0.000\right)$. When Duncan test results are evaluated, it was seen that $H$ values of air-jet yarns are lower than that of Ring yarns for both single and ply-twisted form. More than half of the surface area of air-jet yarns is covered by the layer of wrapper fibers. The lower $\mathrm{H}$ value of air-jet yarns could be explained by the layer of wrapper fibers. In the literature, there are a lot of studies related with MVS yarns which confirm these findings $[2,20]$. As seen in table 6 , there is not a significant difference between $\mathrm{H}$ values of air-jet single yarns. Conversely, the differences between $\mathrm{H}$ values of MVS and RAJ yarns were found to be statistically significant for ply-twisted form. When a general evaluation was made in terms of single and ply-twisted yarns, results show that the increase of $\mathrm{H}$ values after 
Taking unevenness results into consideration, it is seen that the unevenness values of yarns vary for each spinning system, for both single and ply-twisted form. Results imply that the unevenness values of Ring yarns are better than that of air-jet yarns. Also, the worst unevenness value is seen in RAJ yarn, for both single and ply-twisted form.

The test results reveal that air-jet yarns demonstrate worse tenacity and breaking elongation properties than Ring counterparts for both single and ply-twisted form. The possible reason for comparatively lower tenacityvalues of air-jet yarns is the non-uniform load distribution related with the disoriented air-jet yarn structure forming two groups of relatively parallel fibers in the core and wrapping fibers at the sheath. Analysis of test results also shows that hairiness values of air-jet yarns are lower than that of Ring yarns. Specific structure of air-jet yarns having wrapper fibers could be said to be responsible for the considerably low amount of hairs. Furthermore, the difference between hairiness values of air-jet yarns is found statistically insignificant for single form.

\section{BIBLIOGRAPHY}

[1] Örtlek, H.G., Önal, L. The comparative study on the characteristic of knitted fabric made of vortex-spun viscose yarns, In: Fiber and Polymer Science, 2008, vol. 9, pp. 194-199.

[2] Örtlek, H.G., Ülkü, S. The comparison of the properties of murata vortex-ring-and rotor spun cotton yarns, In: 5th International Istanbul Textile Conference Papers, İstanbul, 2005.

[3] Basu, A., Progress in air-jet spinning, In: Textile Progress, 1999, vol. 29, no. 3, The Textile Institute, Manchester.

[4] Erdumlu, N., An approach to investigate the spinnability of fine count yarns on vortex spinning system, In: İstanbul Technical University, Institute of Science and Technology, Phd Thesis, İstanbul, 2011, 154 p.

[5] Basal, G., Oxenham, W. Vortex spun yarn vs. air-jet spun yarn, In: AUTEX Research Journal, 2003, vol. 3. no.3, pp. 96-101.

[6] Örtlek, H.G., Nair, F., Kılık, R., Güven, K. Effect of spindle diameter and spindle working period on the properties of $100 \%$ viscose MVS yarns, In: Fibers\&Textiles in Eastern Europe, 2008, vol. 16, no. 3, pp. 17-20.

[7] Erdumlu, N., Özipek, B., Oxenham, B. Vortex spinning technology, In: Textile Progress, 2012, vol. 44:3-4, pp.141-174.

[8] Erdumlu, N., Özipek, B., Öztuna, A.S., Çetinkaya, S. Investigation of vortex spun yarns properties in comparison with conventional ring and open-end rotor spun yarns, In: Textile Research Journal, 2009, vol 79(7) pp. 585-595.

[9] Eldessouki, M., Ibrahim, S., Farag, R. Dynamic properties of air-jet yarns compared to rotor spinning, In: Textile Research Journal, 2015, vol. 85, no. 17, pp. 1827-1837.

[10] Kireçci, A., Erdal, P. P., İçoğlu, H. İ. Comparison of the fastness properties and color values of cotton fabrics knitted from air-vortex and ring spun yarns, In: TekstilveKonfeksiyon, 2009, vol. 4, pp. 304-311.

[11] Yaşar, T. Evaluation of yarns performances produced with air-jet spinning systems, In: Erciyes University, Institute of Science, Master Thesis, Kayseri, p. 102, 2015.

[12] Kilic, G. B., Okur, A. A comparison for the physical properties of cotton, modal and acrylic yarns spun in ring and OE-rotor spinning systems, In: Industria Textila, 2016, vol. 67, no. 2, pp. 80-89.

[13] Karakan, G., Palamutçu, S., Erdem, R., Abdulla, G. The influence of nozzle pressure and yarn count on vortex spun yarn properties produced by MVS machine, In: Industria Textila, 2016, vol. 66, no.1, pp. 11-18.

[14] Anonymous, Roller jet spinner, In: Customer Information Brochure, Murata Machinery Limited, No. 804, 4 p, 1995.

[15] Murata Vortex Spinner, Instruction Manuel, Murata Machinery Limited, pp. 1-348.

[16] Rieter J 20, Air-jet spinning machine brochure, 2714-v1 tr 1407.

[17] Muratec, Vortex yarn guide book, Cat No.171P4C2- 05-9-3 (NS), 2005. 
[18] Soe, K. A., Takahashi, M., Nakajima, M., Matsuo, T., Matsumoto, T. Structure and properties of MVS yarns in comparison with ring yarns and open-end rotor spun yarns, In: Textile Research Journal, 2004, vol. 74 (9), pp. 819-829.

[19] Haleem, N., Wang, X. Recent research and developments on yarn hairiness, In: Textile Research Journal, Vol. 85(2), pp. 211-224, 2014.

[20] Kilic, M., Okur, A., The properties of cotton-Tencel and cotton-Promodal blended yarns spun in different spinning systems, In: Textile Research Journal, 2011, vol. 81(2), pp. 156-172.

Authors:

\section{HÜSEYIN GAZI TÜRKSOY ${ }^{1}$ \\ TUĞBA AKKAYA ${ }^{1}$ \\ DENIZ VURUŞKAN² \\ SÜMEYYE ÜSTÜNTAĞ ${ }^{1}$}

${ }^{1}$ Department of Textile Engineering, Erciyes University, Kayseri, Turkey

${ }^{2}$ Department of Textile Engineering, Gaziantep University, Gaziantep, Turkey

e-mail: hgazi@erciyes.edu.tr, tugba-erc@hotmail.com,

vuruskan@gantep.edu.tr, sumeyyeustuntag@erciyes.edu.tr

Corresponding author:

SÜMEYYE ÜSTÜNTAĞ

e-mail: sumeyyeustuntag@erciyes.edu.tr

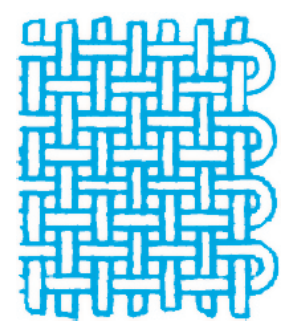




\section{Effects of process variables on physical characteristics of tri-component elastic-conductive composite yarns (t-ECCYs) using a modified ring frame}

\section{REZUMAT - ABSTRACT}

\section{Efectele variabilelor de prelucrare asupra proprietăților fizice ale firelor compozite elastic conductoare tri-componente (t-ECCY) utilizând o mașină de filat cu inele modificată}

S-a demonstrat procedura de fabricație a firelor compozite elastice, conductoare, tri-componente (t-ECCY) cu arhitectură distinctivă, care utilizează un filament de elastan ca miez și un filament din oțel inoxidabil, combinat cu mătase artificială, prin înfășurare elicoidală, în jurul miezului extensibil. A fost aplicată o singură tehnică de analiză factorială pentru a investiga efectele variabilelor de prelucrare, adică spațiul dintre fasciculele de fibre, nivelul de torsiune și viteza fusului, asupra unor properietăți fizice și geometrii de filare ale firelor rezultate, în ceea ce privește tenacitatea la rupere, alungirea la rupere, elasticitatea, pilozitatea, neregularitatea și caracteristicile vizuale. A fost investigat comportamentul electric. Este bine stabilit faptul că variabilele procesului de preparare joacă un rol semnificativ în stabilirea caracteristicilor fizice ale firelor finale. A fost evidențiată relația dintre geometriile de filare și proprietătile firelor. Rezultatele experimentale au arătat că performantele fizice optimizate ale $t$-ECCY s-au obtinut la o distanță între fascicule de $10,5 \mathrm{~mm}$, torsiune de $700 \mathrm{~T} / \mathrm{m}$ și o viteză a fusului de $7000 \mathrm{rpm}$. Firele $t$-ECCY rezultate ar putea reprezenta o propunere de mare valoare pentru utilizări speciale ale textilelor electrice. Firele sunt disponibile ca element senzor de bază cu o elasticitate substanțială și conductivitate ridicată, pot fi prelucrate cu ușurință în țesături prin tehnologii textile convenționale, oferind țesături cu o bună conservare a formei, pe baza elasticității superioare, cu eficacitate de ecranare electromagnetică prin monofilamentul metalic din interior, cu posibilitati de utilizare în viitor ca dispozitive electronice ușoare în miniatură.

Cuvinte-cheie: fir compozit elastic conductor, variabile de prelucrare, filament de elastan, fir de oțel inoxidabil, textile funcționale, filare cu inele modificată

\section{Effects of process variables on physical characteristics of tri-component elastic-conductive composite yarns (t-ECCYs) using a modified ring frame}

The fabrication procedure of tri-component elastic-conductive composite yarns (t-ECCYs) with distinctive architecture, which employs elastane filament as a core and stainless steel filament combining with rayon assemblies as a helical winding around the extensible core, was demonstrated. Then, a single factorial-analysis technique was applied to investigate the effects of processing variables, i.e., strand spacing, twist level and spindle speed, on some physical characteristics and spinning geometries of the resultant yarns, in terms of breaking tenacity, extension at break, elasticity, hairiness, unevenness, and visual features. Then, the electrical behavior was conducted. It is well established that the preparatory process variables play a significant role in deciding the physical characteristics of the final yarns. The Relationship between spinning geometries and yarn properties were highlighted. Experimental results revealed that the optimized physical performances of t-ECCYs were obtained at $10.5 \mathrm{~mm}$ strand spacing, $700 \mathrm{~T} / \mathrm{m}$ twist, and 7000 rpm spindle speed. The resultant $t$-ECCYs could be a high-valuable proposition for special purposes in electrical textiles. The yarn itself is available as a base sensor element with substantial stretch and high conductivity, and such yarns could be easily processed into fabrics by conventional textile means offering fabrics with good shape preservation based on superior elasticity, even electromagnetic shielding effectiveness with metal monofilament inside, and can thus be applied as lightweight miniature electronics in the future.

Keywords: elastic-conductive composite yarn, process variables, elastane filament, stainless steel wire, functional textile, modified ring spinning

\section{INTRODUCTION}

Elastic-conductive yarns having the potential to be used in e-textiles have been of a mainstream research direction, and such yarns could enable a spectrum of applications, e.g., electrodes, sensors [1-3]. Moreover, abundant studies of yarns will result in new discoveries that push the boundaries of science forward. In general, elastic-conductive yarns are extensively produced by chemical techniques, but several limitations exist including insufficient adhesion, a complex fabrication procedure, and a large ecological footprint. Making yarns mentioned use physical actions, and yarns that can be easily processed into fabrics using traditional textile means, are desperately needed. However, little information can be found on elastic-conductive composite yarns using spinning method, and the potential of ring spinning for such yarn production is not fully exploited yet 
[2-4]. Therefore, further efforts are still urgent to produce yarns that meet above requirements from the viewpoint of materials exploration and fabrication strategy.

Ring spinning, a versatile technique, is broadly used for producing requested yarns in virtue of prominent structural architecture [5]. It is well established that the process variables and spinning geometry play a crucial role in deciding the characteristics of final yarns. Traditionally, many studies are available on the effects of process variables on some physical properties of two-strand yarns, e.g., core, siro, sirofil [6]. Cheng et al investigated the effects of varying strand spacing and twist multiplier on cotton sirospun yarns and founded that higher spacing gave superior properties in terms of tenacity, trapped strand twist and abrasion resistance [7]. Soltani et al pointed out that fiber-migratory properties are considerably affected by strand spacing and twist multiplier [8]. Gowda et al studied the effects of strand spacing, traveller mass, and spindle speed on the properties of model sirospun yarns [9]. In literature, there is hardly any mention on tri-axial ring spinning of elastic-conductive yarns. Since the behavior of yarns is highly variable and depends on many technological parameters, a systematic study of spinning process and effects of variables on some properties of the resultant yarns are required for optimizing the spinning process as a whole.

Herein, the fabrication of tri-component elastic-conductive composite yarns (t-ECCYs) consisting of stainless steel filament (SSF), elastane filament (EF), and rayon fibers (RFs) was described, and the effects of process variables, viz. strand spacing, twist, and spindle speed, on some physical characteristics of the resultant yarns, were investigated, in detail, in terms of tensile behavior, elastic recovery, hairiness, unevenness, and visual appearances. Thereafter, experiments on resistance were performed systematically. Finally, the avenues for further research were put forward.

\section{EXPERIMENTAL DETAILS}

\section{Raw materials}

In this study, the rayon fibers (RFs) of $1.33 \mathrm{dtex}$ and $38 \mathrm{~mm}$ were used to produce rayon roving (RR) of 568.5 tex. Stainless steel filament (SSF, AISI type $316 \mathrm{~L}$ ) was taken as a conductive material with diameter of $30 \mu \mathrm{m}$. Also, elastane filament (EF) was utilized as an elastic one with linear density of $140 \mathrm{D}$.

\section{Composite yarn manufacturing}

A schematic of t-ECCY production is shown in figure $1, a$. A conventional ring frame is retrofitted with a grooved roller, positive feed rollers and a tension disc. The grooved aluminum roller was precisely designed and installed on the roller-weighting arm to increase the feed-stability of SSF and EF. In detail, it is mounted just above the upper front roller and rotated with it due to its delicate design with two bearings inside. Draft ratio of EF was controlled through speed differences between positive feed rollers and front rollers. The preload of SSF was conducted by a tension disc and measured by a tension meter. In figure $1, b$, the fabrication procedure of yarns involves two steps: (i) combination of RR and SSF, forming a SSF core yarn, at convergence point $A$; (ii) compound formation of SSF core yarn and EF, at convergence point $B$. In addition, the real spinning processes of front-rear views were depicted in figure $1, c-d$. The photographic representations of elongation of specimen-R2 in initial-straighten states are depicted in figure $1, e$. The yarn in initial state has a more bulking morphology compared with the straighten one. It can tolerate strain up to about $300 \%$ without pulling apart,

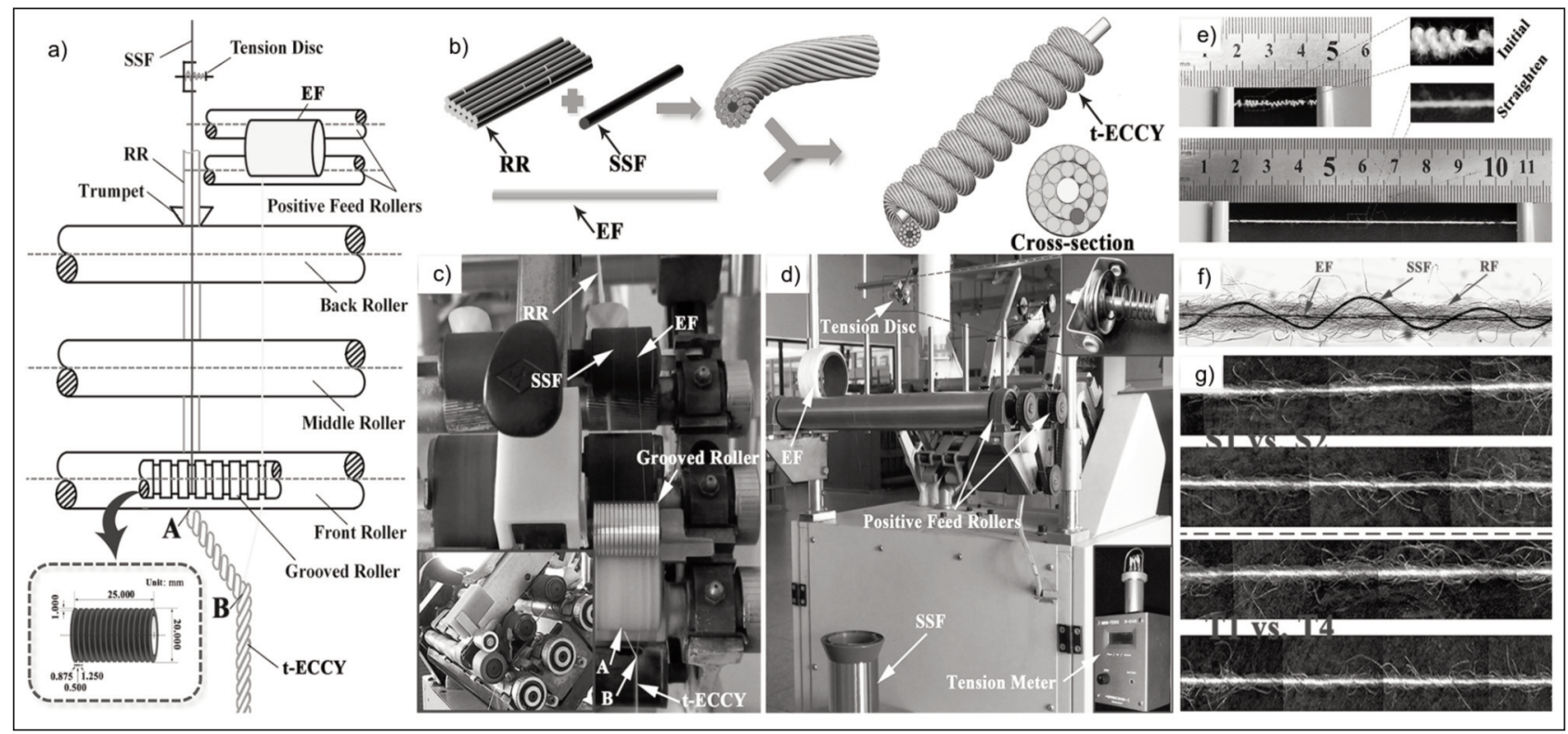

Fig. 1. $a$-schematic of fabrication process of t-ECCY; $b$ - graphic representation of two-step yarn manufacturing; $c-d-$ real process of front-rear views; $e-f-$ photographic representation of elongation of yarns-R2 in initial and straighten states, and positions of EF and SSF inside; $g$ - comparisons of yarn appearances, i.e., S1 vs. S2, T1 vs. T4 


\begin{tabular}{|c|c|c|c|}
\hline Constant parameters & Values & Varying parameters & Values \\
\hline Total draft/Break draft & $18.08 / 1.20$ & Strand spacing/mm & $7.0, \mathbf{1 0 . 5}, 14.0,17.5$ \\
\hline Elastane draft of EF & 3.0 & Twist $/ \mathrm{T} \cdot \mathrm{m}^{-1}$ & $600, \mathbf{7 0 0}, 800,900$ \\
\hline Pretension of SSF/cN & $10-12$ & Spindle speed/rpm & $\mathbf{5 5 0 0 , 7 0 0 0 , 8 5 0 0 , 1 0 0 0 0}$ \\
\hline
\end{tabular}

mainly owing to the specific architecture, which employs EF as a core and SSF as a helical winding around, shown in figure $1, f$. The image was captured by dipping the yarns with $0.5 \mathrm{cN} /$ tex preload in methyl salicylate for a very short time. Also, two photographs (S1 vs. S2, T1 vs. T4) were presented in figure 1, g. A good SSF and EF replacement in the yarn structure was obtained. By contrast, S2 and T4 samples have less hairy compared with $\mathrm{S} 1$ and $\mathrm{T} 1$, respectively. In the field of yarn spinning engineering, processing parameters play a decisive role in influencing the quality characteristics of resultant yarns. The detailed spinning particulars were summarized in table 1. Total 12 yarn specimens, viz., S1-S4, T1-T4, and R1$\mathrm{R} 4$, were fabricated covering preparatory process variables in strand spacing, twist and spindle speed using a single factorial-analysis technique. Noting the process variable value represented in Bold-ItalicType, the relevant yarns were produced by varying one of the three variables, keeping the other two variables constant. For instance, in order to study the spacing-effect, four specimens (S1-S4) were produced at twist of $700 \mathrm{~T} / \mathrm{m}$, and spindle speed of $5500 \mathrm{rpm}$.

\section{RESULTS AND DISCUSSION}

\section{Spinning geometry}

A SONY digital camera was used to capture the spinning geometry in the yarn formation zone [6]. Midway through the spinning, we recorded the process for a certain time, and then we randomly extracted 100 graphs for each condition. The spinning geometries with respect to varying technological parameters were shown in figure 2. As can be seen, the shapes of spinning triangles concerning process variables were obviously asymmetric, primarily due to modulus differences of the two sub-strands, that is, nominal SSF core yarn and EF. Processing variables, e.g., strand spacing, twist, and spindle speed, are vital factors that affect the yarn properties because they control the spinning geometries of the resultant yarns..

\section{Tensile characteristics and rupture behaviour}

The tensile strength was tested at $500 \mathrm{~mm} / \mathrm{min}$ and $500 \mathrm{~mm}$ gauge length. A preload of $0.5 \mathrm{cN} / \mathrm{tex}$ was adjusted. Results from figure $3, a-b$ indicate that with increasing spacing up to $14.0 \mathrm{~mm}$, yarn tenacity and elongation increase beyond which they reduce. Increasing spacing raises applied tension on fibers in the spinning triangle [8]. Further with an increase of spacing, the tension of strands became so great that the convergence point shifts sideways apparently (seen in figure 2, a), causing more unequal stretch in the strands. Due to the poor axial orientation of fibers rather than cohesion, fiber sliding, lower fiber-control [8], and few fiber-loss by pneumafil, tensile behaviors deteriorate consequently [9]. Referring to figure 3,c, the yarn reaches maximum strength at moderate twist $(700 \mathrm{~T} / \mathrm{m})$. If the twist is lower, the sheath does not cover the core properly. Besides, yarn tenacity would decrease with higher twist, mainly due to the decreasing yarn loading capacity and increasing prestress on individual fibers. Regarding the elongation, higher values are obtained with the increasing twist, illustrated in figure 3,d. Shown in figure 3,e, yarn tenacity increases gradually as spindle speed increases. As the speed increases, the force flung by the air loops increases and makes core being wrapped more tightly, heightening the axial strength of yarns. The results from figure $3, f$ reveal that with increasing speed up to $7000 \mathrm{rpm}$, elongation at break increases, beyond which it reduces marginally. The centrifugal force and fiber-loss at $10000 \mathrm{rpm}$ are responsible for the reduced extension. In addition, difference in mean values between groups was analyzed for statistical significance using one-way ANOVA by Minitab 17. As
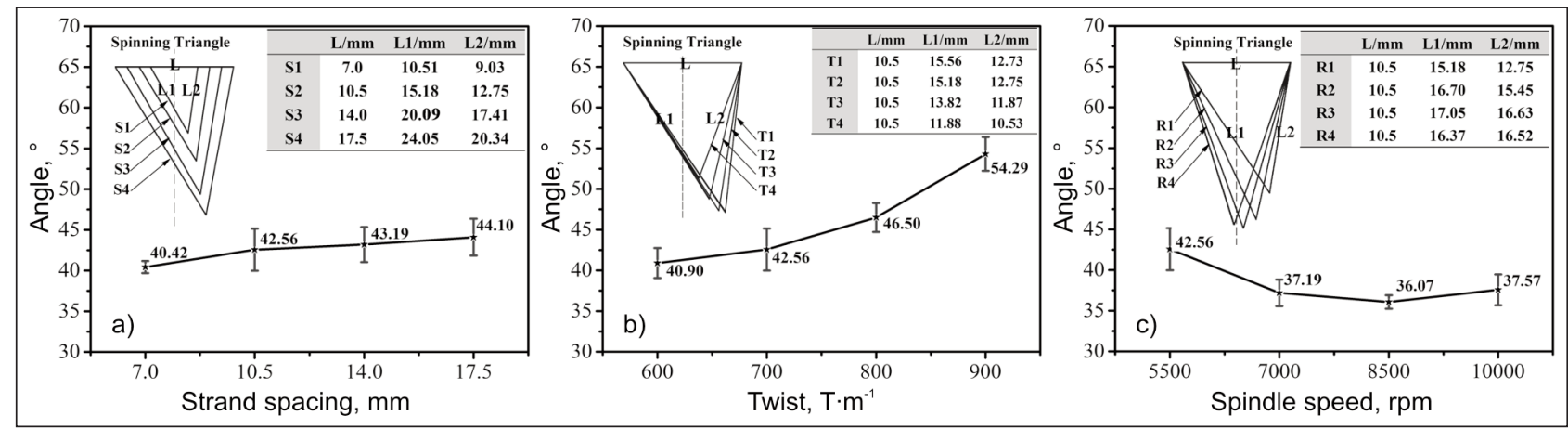

Fig. 2. Relationship between process variables and spinning geometries of the twisting triangle 

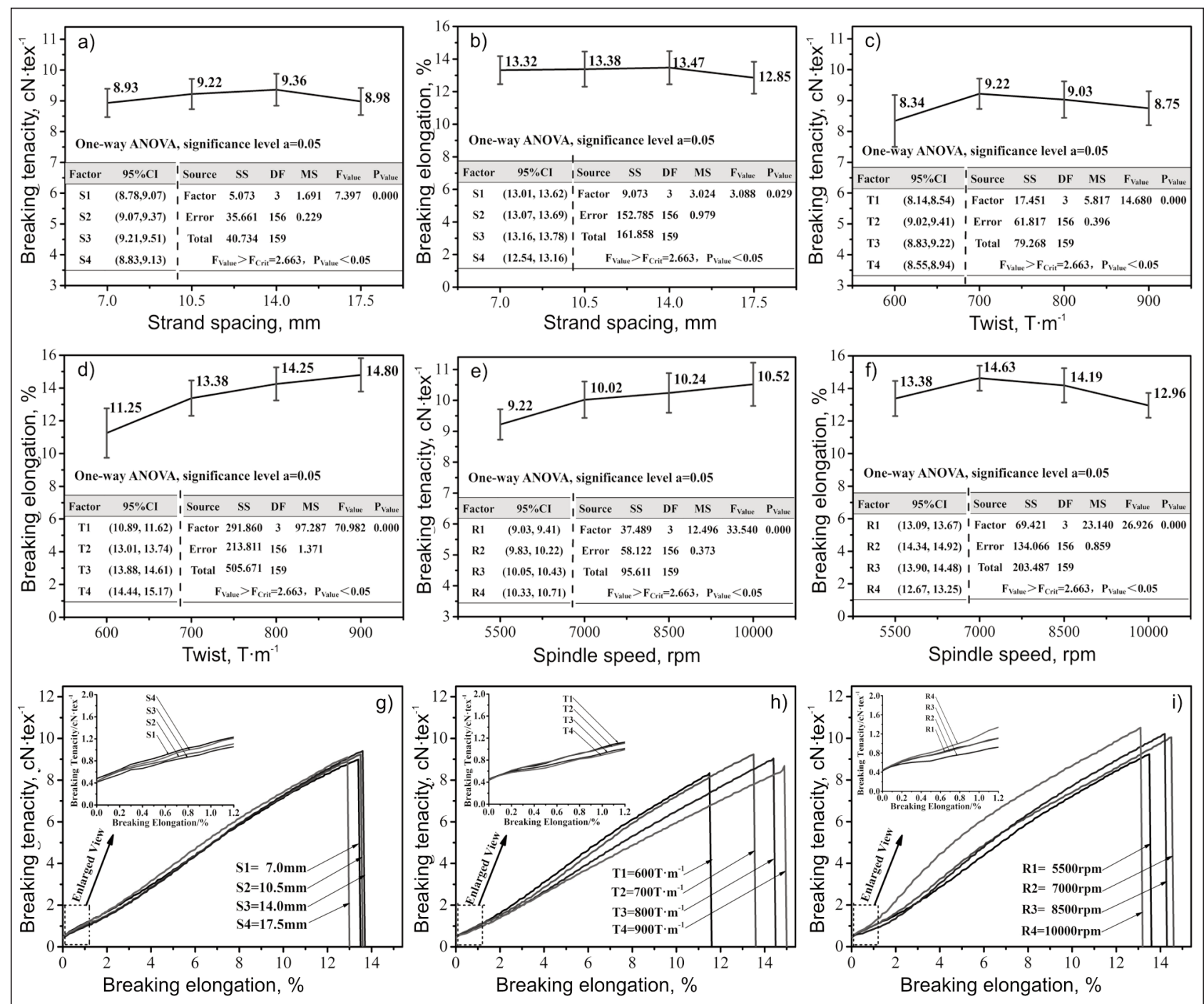

Fig. 3. Effects of process parameters, i.e., $a-b-$ strand spacing, $c-d-$ twist and $e-f-$ spindle speed, on tensile properties of t-ECCYs; typical curves at individual variable of $g$ - strand spacing, $h-$ twist, and $i-$ spindle speed

given, the differences between each process parameter were significant with $\mathrm{P}_{\text {value }}(<0.05)$, demonstrating that the preparatory variables were essential fundamentally.

Typical stress-strain curves of t-ECCYs at varying process variables were graphically displayed in figure $3, g-i$, respectively. The shapes of all the curves are essentially nonlinear, with an initial concavity and a consequent convexity characteristic. A typical characteristic of easily extensible yarns to possess a lower Young's modulus, shown in the dotted rectangle of each graph, was observed due to the presence of EF and helical disposition of SSF inside (figure 1,f). As for figure $3, g$, the characteristics do not change much among the curves obtained at different strand spacing. With respect to figure $3, h$, the mechanical properties of the yarns, especially the elongation at break, are diverse, ranging from about $11.5 \%$ up to $15.0 \%$. In the case of figure $3, i$, the curves obviously shift towards the tenacity axis with an increasing spindle speed.

\section{Elastic recovery}

Elastic recovery was obtained with gauge length of $500 \mathrm{~mm}$, speed of $500 \mathrm{~mm} / \mathrm{min}$, preload of 0.2 $\mathrm{cN} /$ tex, initial extension of $6 \%$, and retention period of 30 s. 15 measurements were taken. Seen in figure 4 , the variations in elastic recovery are not dramatically significant concerning the strand spacing. The elastic recovery increases with increasing spacing and then decreases when it reaches $17.5 \mathrm{~mm}$. With respect to the twist, it exhibits an ascending trend, which is the expected consequence of fortified cohesion of interfibers caused by higher twist, thus, restricts the mutual slippage [10]. As for the spindle speed, it exhibits a distinct upward trend. It increases dramatically up to $7000 \mathrm{rpm}$, beyond which it increases marginally.

\section{Yarn hairiness and unevenness}

The hairiness was measured by a YG172A hairiness tester on $100 \mathrm{~m}$ of yarns at $30 \mathrm{~m} / \mathrm{min}$. Figure 5 , a illustrates the effects of technological variables on the hairiness index $(\mathrm{HI})$. Note that the shape of curves is concave-down in all cases. The increase in strand spacing, twist and spindle speed result in a decrease 


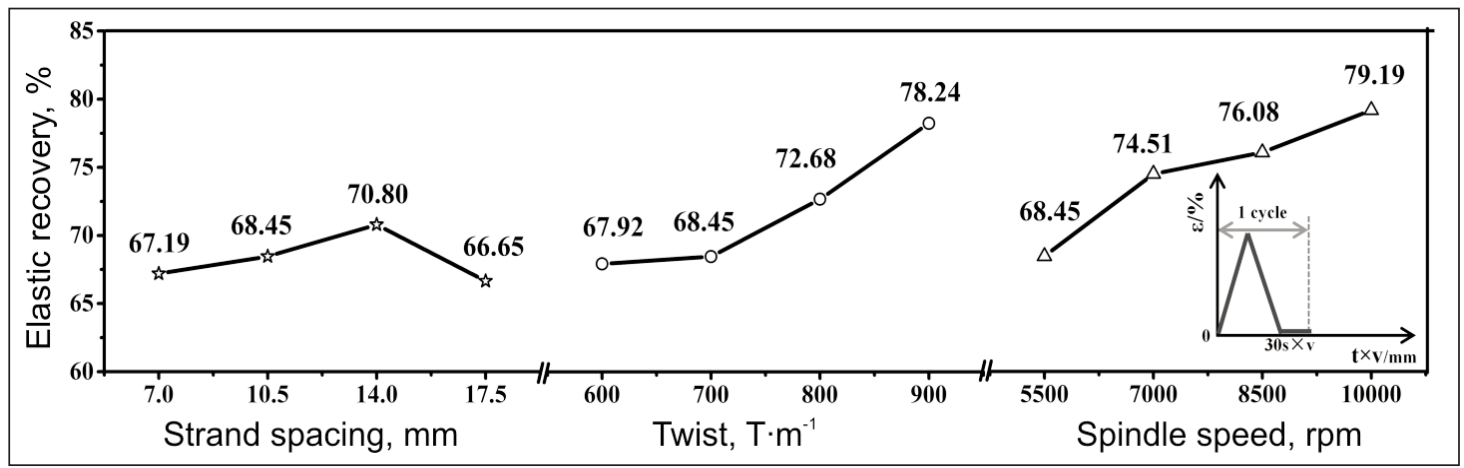

Fig. 4. Elastic recovery characteristics of t-ECCY specimens at varying process parameters

in yarn hairiness on the whole. Seen the histogram, S3 reduces by $60.7 \%$ when the spacing is increased from 7.0 to $10.5 \mathrm{~mm}$, but afterwards it increases gradually. Increased spacing results in greater strand length and strand angle leading to better trapping-in of surface fibers from strands at convergence point [7]. Also, the increased spacing causes loss in some short fibers [9]. However, the time-spending effect and totally uncontrolled process happen with further increasing spacing. The S3 values are lower with the increasing twist. As twist increases, more torque and cohesion are applied at twisting zone and thus the probability of fibers being embedded into the main body increases, and the draft fibers are easily controlled since the spinning geometry gets smaller (figure $2, b$ ). With increasing spindle speed, the hairiness decreases. The air turbulence and the spinning tension are responsible for the reduced hairiness.

A cut-weigh method was used to evaluate the unevenness. $10 \mathrm{~m}$ yarn with $1.2 \mathrm{cN} /$ tex preload was cut into 60 short-segments, the consecutive one was weighted. Thus, the mass of each length was plotted. The scatter of points will give a visual indication. Afterwards, the percentage mean deviation (PMD) and coefficient of variation (CV), were obtained. Results from figure $5, b$ signify that with increasing spacing up to $10.5 \mathrm{~mm}$, the unevenness decreases beyond which it increases marginally. Increasing twist was found to decrease the unevenness, mainly due to tighter packing density. However, there was no specific trend of variation with different speeds. By contrast, a higher speed was found to cause higher unevenness.
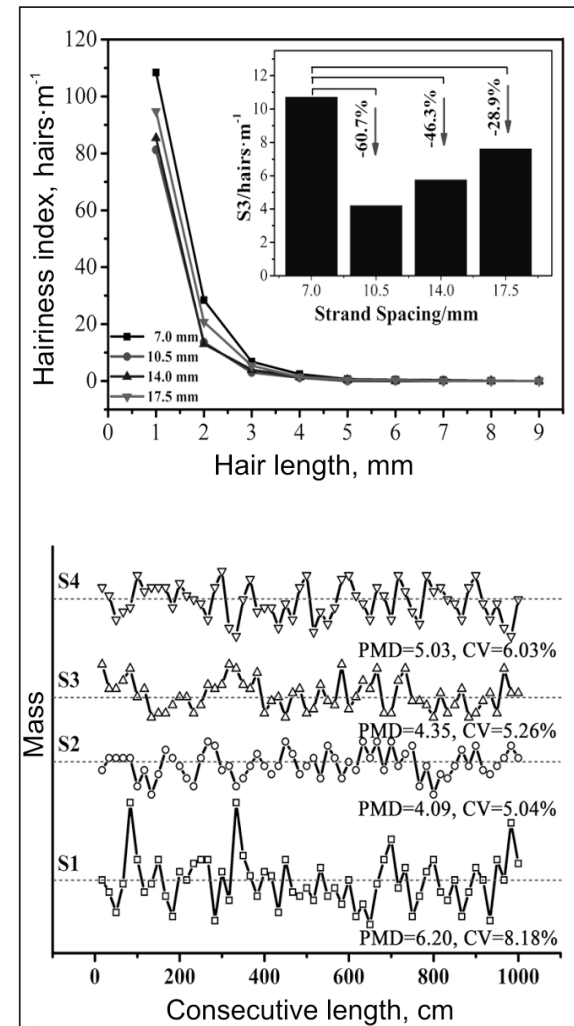

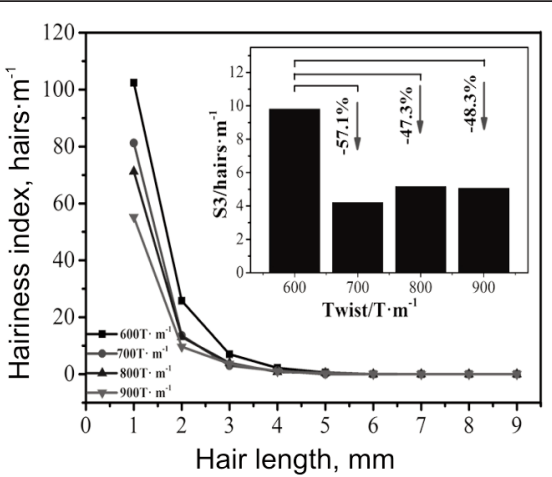

a

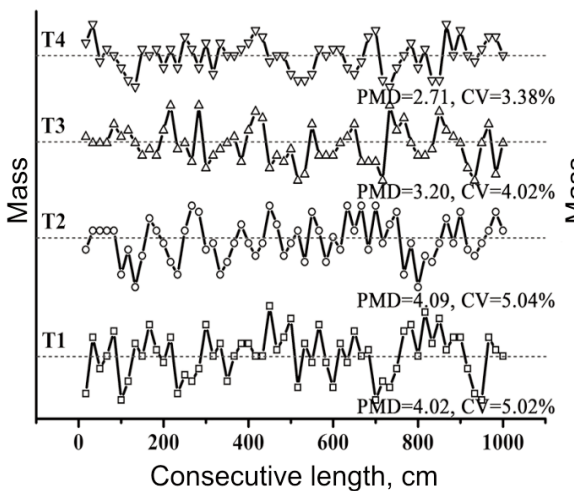

b
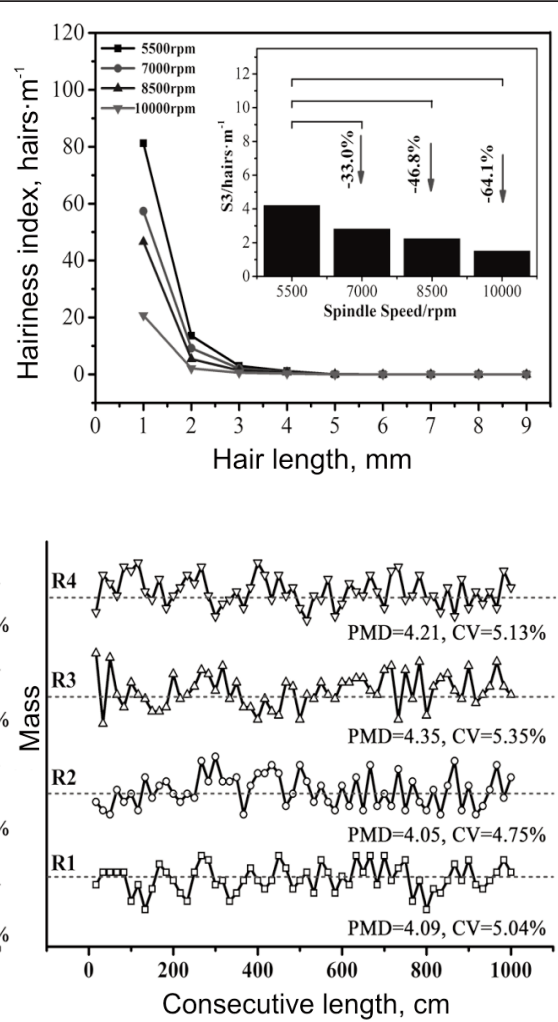

Fig. 5. a - effects of technological parameters, viz. strand spacing, twist, and spindle speed, on the yarn hairiness; $b$ - mass versus consecutive-length curves in terms of spinning parameters, and the calculated results 

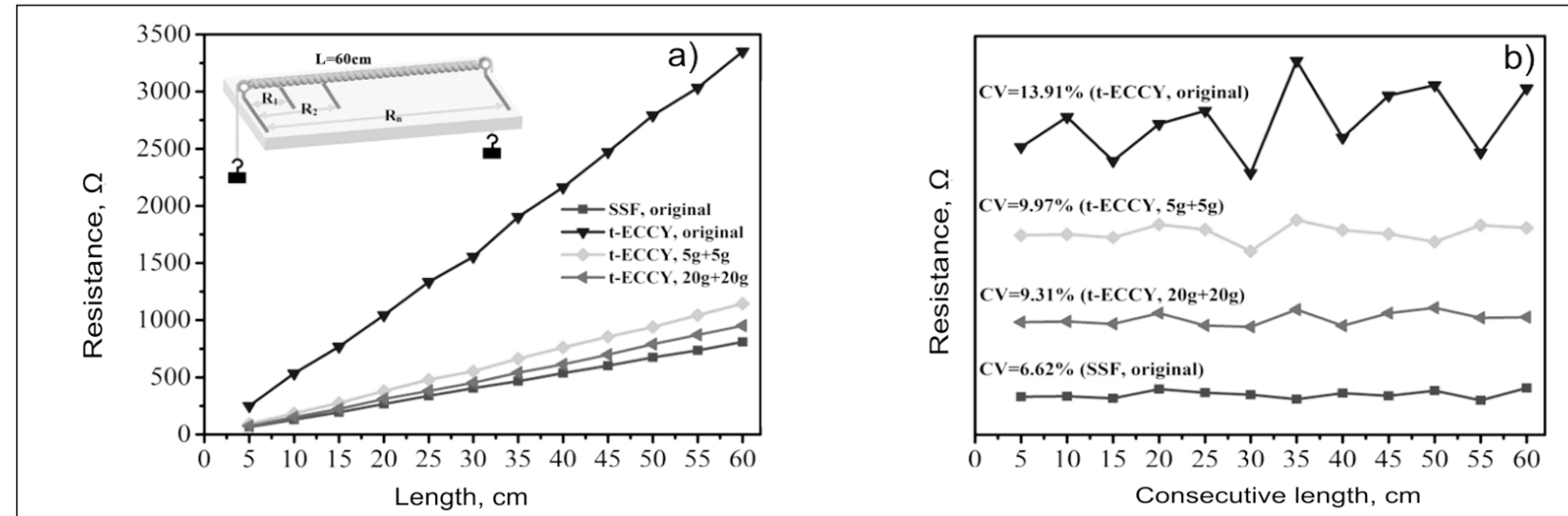

Fig. 6. $a-$ resistance and $b-\mathrm{CV}_{\mathrm{R}} \%$ plotted versus varying lengths and loadings of SSF and $\mathrm{t}-\mathrm{ECCY}$

\section{Electrical behaviour}

Considering the results above, it can be said that $\mathrm{t}$-ECCYs produced at $10.5 \mathrm{~mm}$ spacing, $700 \mathrm{~T} / \mathrm{m}$ twist, and $7000 \mathrm{rpm}$ spindle speed exhibited robust tensile properties, acceptable elasticity, lower hairiness and unevenness. Therefore, they were chosen for the subsequent electrical characterization. The resistance of $\mathrm{t}$-ECCYs was measured for varying lengths and loadings using two-electrode technique from the naked ends of SSF with an Applent AT510 resistance tester having 10 replications. Results in figure 6 , a showed that the resistance across varying intervals increased linearly with testing length of t-ECCYs with original state. The resistance of naked SSF was also measured. The SSF and t-ECCY have a linear relation to the length with a resistance of 13.5 and $56.5 \Omega / \mathrm{cm}$, respectively. When the loading was applied to the yarn ends, the actual length of SSF at a given testing length decreased. Consequently, the resistance maintained a linear dependence with descending slopes of $56.5,19.1$ and $15.9 \Omega / \mathrm{cm}$, respectively. Furthermore, the values of $\mathrm{CV}_{\mathrm{R}}$ of consecutive lengths of SSF and t-ECCY were illustrated in figure $6, b$. Linear change of $\mathrm{R}$ through the entire length regardless of original or tensional state suggests a uniform yarn structure and deformation. As a result, the t-ECCY itself can be used as a yarn-based sensor, which is more comfortable in wearing, easier to be fabricated by conventional textile process, better in style design [3].

\section{CONCLUSIONS}

A straightforward way to manufacture t-ECCYs based on a modified ring system was described, which employs EF as a core and SSF combining with rayon fibers as a helical winding around the core. Thereafter, a single factorial-analysis technique was applied to investigate the effects of spinning variables, viz., strand spacing, twist, and spindle speed, on some characteristics of resultant yarns. It was established that the preparatory process variables play a vital role in deciding the characteristics. Relationship between spinning geometry and performances was highlighted. The results revealed that t-ECCYs enjoyed robust tensile properties, acceptable elasticity, superior conductivity, lower hairiness and unevenness at strand spacing of $10.5 \mathrm{~mm}$, twist of $700 \mathrm{~T} / \mathrm{m}$, and spindle speed of $7000 \mathrm{rpm}$. As a result, such t-ECCYs could be a high-valuable proposition for special purposes in e-textiles. The yarn itself is available as a base sensor element, i.e., yarnbased sensor, and such yarns could be processed into fabric sensors easily. Such fabrics fulfilling the primary duties of textiles can be applied as lightweight miniature electronics in the future. Next, we aim to analysis the mutual relationships between processing parameters and spinning geometries theoretically and moreover, to construct woven and knitted fabric-sensors with the t-ECCYs, and to study the sensors' performance after single/cyclic stretchrecovery tests, washing, and in different climate conditions. Obviously, such work to address the issues would be very useful.

\section{ACKNOWLEDGEMENTS}

This work was supported by the Fundamental Research Funds for the Central Universities (CUSF-DH-D-2017018).

\section{BIBLIOGRAPHY}

[1] Rattfält, L., Lindén, M., Hult, P., Berglin, L., Ask, P. Electrical characteristics of conductive yarns and textile electrodes for medical applications, In: Medical \& Biological Engineering \& Computing, 2007, vol. 45, no. 12, pp. 1251-1257.

[2] Guo, L., Berglin, L., Mattila, H. Improvement of electro-mechanical properties of strain sensors made of elasticconductive hybrid yarns, In: Textile Research Journal, 2012, vol. 82, no. 19, pp. 1937-1947. 
[3] Huang, C.T., Tang, C.F., Lee, M.C., Chang, S.H. Parametric design of yarn-based piezoresistive sensors for smart textiles, In: Sensors and Actuators A: Physical, 2008, vol. 148, no. 1, pp. 10-15.

[4] Schwarz, A., Kazani, I., Cuny, L., Hertleer, C., Ghekiere, F., Clercq, G.D., Mey, G.D., Langenhove, L.V. Comparative study on the mechanical properties of elastic, electro-conductive hybrid yarns and their input materials, In: Textile Research Journal, 2011, vol. 81, no. 16, pp. 1713-1723.

[5] Ortlek, H.G., Kilic, G., Bilgin, S. Comparative study on the properties of yarns produced by modified ring spinning methods, In: Industria Textila, 2011, vol. 62, no. 3, pp. 129-133.

[6] Hua, T., Tao, X.M., Cheng, K.P.S., Xu, B.G. Effects of geometry of ring spinning triangle on yarn torque. Part I: analysis of fiber tension distribution, In: Textile Research Journal, 2007, vol. 77, no. 11, pp. 853-863.

[7] Cheng, K.P.S., Sun, M.N. Effect of strand spacing and twist multiplier on cotton sirospun yarn, In: Textile Research Journal, 1998, vol. 68, no. 7, pp. 520-527.

[8] Soltani, P., Johari, M.S. Effect of strand spacing and twist multiplier on structural and mechanical properties of siro-spun yarns, In: Fibers and Polymers, 2012, vol. 13, no. 1, pp. 110-117.

[9] Gowda, R.V.M., Sivakumar, M., Kannan, M.S.S. Influence of process variables on characteristics of modal siro-spun yarns using Box-Behnken response surface design, In: Indian Journal of Fibre and Textile Research, 2004, vol. 29, no. 4, pp. 412-418.

[10] Su, C.I., Yang, H.Y. Structure and elasticity of fine elastomeric yarns, In: Textile Research Journal, 2004, vol. 74, no. 12, pp. 1041-1044.

Authors:

\section{WANG YONG \\ YU WEIDONG \\ WANG FUMEI}

Donghua University, College of Textiles, Key Laboratory of Textile Science \& Technology, Ministry of Education, 2999 North Renmin Road, Songjiang District, 201620, Shanghai, P.R. China e-mail: yongwang0122@126.com,wdyu@dhu.edu.cn, wfumei@dhu.edu.cn

\section{Corresponding author:}

\section{YU WEIDONG}

e-mail: wdyu@dhu.edu.cn

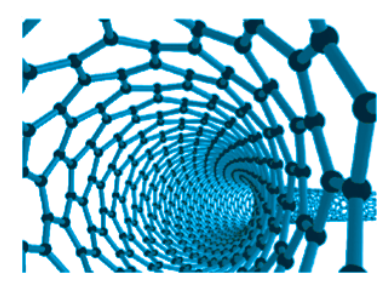




\title{
Developing a modular apparel safety architecture for supply chain management: the apparel recycle perspective
}

\author{
DOI: 10.35530/IT.069.01.1380
}

\begin{abstract}
REZUMAT - ABSTRACT
Dezvoltarea unei arhitecturi modulare în ceea ce privește siguranța îmbrăcămintei pentru managementul lanțului de aprovizionare

Această lucrare prezintă o problemă specială referitoare la opțiunile strategice pentru implementarea îmbrăcămintei reciclabile. O implementare substanțială privată este necesară în cazul în care trebuie să se atingă obiectivele de management ale întreprinderii cu scopul de a crește cota de îmbrăcăminte reciclabilă și de a preveni riscul de producere a îmbrăcămintei nocive. Scopul acestei lucrări și întreaga abordare este de a atrage atenția asupra proceselor care stau la baza alegerilor strategice pentru implementarea îmbrăcămintei reciclabile. S-a elaborat și implementat un cadru de arhitectură modulară pentru siguranța îmbrăcămintei (MASA) pentru managementul lanțului de aprovizionare cu scopul de a oferi orientări pentru designerii și producătorii de îmbrăcăminte pentru ca aceștia să rezolve problemele de siguranță și durabilitate legate de producția de îmbrăcăminte. Cadrul MASA a fost dezvoltat prin integrarea unei teorii modulare și a conceptului de produs reciclabil în designul și producția existentă a îmbrăcămintei. Designul și producția de îmbrăcăminte pentru copii au fost utilizate pentru a pune în aplicare cadrul MASA ca un concept real. Cadrul MASA este primul model de design și producție a îmbrăcămintei care subliniază siguranța și reciclabilitatea, în plus față de considerentele funcționale, expresive și estetice. Originalitatea acestei lucrări este capacitatea acesteia de a combina aspectele sociale, tehnice, de mediu și economice utilizând o teorie modulară cu scopul de a oferi un punct de vedere holistic asupra factorilor care influențează sistemul de îmbrăcăminte reciclabil prin proiectarea și dezvoltarea modulelor de management reciclabil.
\end{abstract}

Cuvinte-cheie: siguranța îmbrăcămintei, sistem de îmbrăcăminte reciclabilă, design modular, managementul lanțului de aprovizionare

\section{Developing a modular apparel safety architecture for supply chain management: the apparel recycle perspective}

This paper introduces the special issue on strategic choices for recyclable clothing implementation. Substantial private implementation is needed if company management objectives to increase the share of recyclable clothing and prevent dangerous clothing risk be achieved. The aim of this paper, and the entire special issue, is to draw scholarly attention to the processes underlying strategic choices for recyclable clothing implementation. An modular apparel safety architecture (MASA) framework for supply chain management was developed and implemented to provide guidelines for apparel designers and manufactures to solve safe and sustainable problems related to apparel production. The MASA framework was developed by integrating modular theory and product recyclable concept into existing apparel design and production. Children's clothing design and production was used to implement the MASA framework as a proof concept. The MASA framework is the first apparel design and production model that emphasizes safety and recyclability in addition to functional, expressive, and aesthetic considerations. The originality of this work is its ability to combine social, technical, environmental and economic aspects using modular theory in order to provide a more holistic point of view on factors impacting recyclable clothing system through the design and development of recyclable management modules.

Keywords: apparel safety, recyclable apparel system, modular design, supply chain management

\section{INTRODUCTION}

The limited reserves and negative environmental impacts associate with fossil fuel consumption make the recyclable clothing considerable alternatives in case environmental externalities and sustainability are taken into consideration [1]. In addition, increasing use of recyclable clothing is a vital importance in mitigating increasing resource shortage and waste clothing to accomplish sustainable development. Recyclable clothing is becoming increasingly important for recycling economies in many countries. But still in an emerging industry, recyclable clothing requires supportive management policy helping firms to develop and protect competitive advantages in global competition. Apparel recycling is also a major energy-saving and environment-friendly strategic emerging industry in the world, and a prioritized management strategy for apparel recycling should be established for the maximum apparel recycling.

A detailed understanding of apparel safety and apparel recycle in the textile industry is critical for fair and equitable apparel supply chain management policies. This study adds new perspective on the role 
of textile process innovation for reducing the risks of textile sector. In the literature on apparel safety and recycle, important headway has been made in understanding the factors that drive apparel safety and apparel recycle strategies, such as apparel safety sources and recall activities [2-3]. However, less attention has been paid to the determinants of the adoption of recyclable safety apparel supply chain management that aim to reduce the apparel risk, recycle costs and add reuse value. Such management strategies include the sourcing of apparel raw material, design or production that result in the decomposition of the apparel for recycling.

This article has proposed an integration of design for disassembly into the modularization framework and apparel supply chain to measure apparel safety and recycles. Policy-makers can use those insights for designing policy that supports recyclable clothing implement with a scope on customer safety needs rather than technology or price. Additionally, we state important implications for recyclable clothing entrepreneurs, managers and research, and therefore, such a research is of interest for entrepreneurs and managers for understanding how to adjust their initiatives with the apparel safety's requirements and thus increasing the likeliness of recycling success.

\section{BACKGROUND AND ORGANIZATION OF THE PAPER}

The paper describes recyclable clothing system, an integrated modular approach for maximizing safety, recyclability, performance, ecological efficiency and profitability in the textile industry. The fundamental principles of integrated recyclable clothing system provide a global roadmap to a recyclable economy based on the closed loop supply chain. The purpose of this paper is to develop and implement a kind of modular apparel safety architecture (MASA) framework for supply chain management, which provides guidelines for apparel designers and manufactures to solve safe and sustainable problems related to apparel production. The MASA framework was developed by an integration of design for disassembly into the modularization framework and closed loop apparel supply chain to measure apparel safety and recycles. Children's clothing design and production was used to implement the MASA framework as a proof concept.

The originality of this work is its ability to combine safety, technological and environmental aspects using modularity theory in order to provide a more holistic point of view on factors impacting closed loop apparel supply chain. This study adds new perspective on the role of textile process innovation for reducing the risks of textile sector. We intend to contribute in several areas: we provide insight on recyclable clothing companies' strategic implementation framework. They have implications for management policy and may serve as indicator for designing effective implementation plan that fosters competitiveness of recyclable clothing firms and contributes to further dif- fusion of recyclable clothing. Further, entrepreneurs and managers may utilize the results for formulating corporate strategies and designing business management models. A peripheral contribution is to research on decision-making in sustainable supply chain management. Our work enhances the concept of closed loop apparel supply chain by contributing explorative evidence on the value of different green management components from a managements' point of view.

We proceed as follows: in the next section we briefly discuss apparel safety and closed loop supply chain. The featured understanding of apparel safety serves as the basis for the module design later on. Then, we discuss aspects of apparels to characterize business managers for recyclable clothing in general and to better understand whom we asked. In the module section, we elaborate on the safe-based conjoined modular units. We then present our results and explore modular apparel safety architecture framework and state propositions from managerial and operational levels. Based on the stated framework, we model generic recyclable implementation modules for children's clothing. We wrap up by drawing conclusions and pointing to potential implications for clothing policy and for recyclable clothing entrepreneurial and managerial practice and research.

\section{LITERATURE REVIEW}

\section{Apparel safety}

Apparel safety becomes higher qualifying 'ticket' for the product to enter the market. In fact, quite a number of technical regulations and standards to consider apparel safety have developed and the market becomes more sophisticated, which aims to see that apparel must meet requirements of the safety test in various countries. An objective analysis of user safety needs uncovered through technical regulations/ standards and recall cases led to the development of apparel safety categories and indicator inventories [4]. The evaluation method of apparel safety has been studied over the years. Wu conducted a safety risk evaluation model for textile and apparel by the method of BP neural network that has been proved in a step-by-step way using practical inspection data [5]. A risk assessment model integrating the SVM technology was developed for measuring the textile and apparel safety [6]. Zhou studied the potential mechanical hazards of children's clothing by the method of fault tree [7]. Pang further conducted risk assessment for textile and apparel by the application of TS fuzzy neural network [8]. The design of ecological textile messages was presented to use environmental-friendly technology and raw materials in textile product design for reducing toxic chemical substances in children's clothing [9]. On the whole, apparel safety management is obviously important in apparel reuse and recycle. Effective reuse and recycle of textile and apparel requires an accurate prediction of the quality of textile and apparel parts 
generated. However, the recycle and reuse incorporating safety in apparel supply chain management is not well structured. Specifically, it is not clear how apparel safety management is related to apparel recycle and reuse.

\section{Apparel recycle and reuse}

According to Gam and Cao, cradle to cradle apparel design is a new sustainable apparel design and production model, which emphasizes sustainability and recyclability in apparel supply chain [1]. The application of design for disassembly methods in men's jacket design and construction were conducted to show a design for recycle or reuse different materials and components at the end of the jacket's usable life [10]. Pattern transformation were applied in clothing and tent design and experimentally demonstrated that outdoor clothing and tent with similar application occasions and raw materials, which could realize recycle and reuse design goal by wearing and assembling [11]. The technical experiment for clothing style change were conducted by the transformation design of clothing structure elements to enable raw materials for one garment to could be reused for two or more garments [12]. Textile waste recycling and sustainable development were studied to achieving environmental sustainability [13].

Textiles are a largely untapped consumer commodity with a strong reuse and recycling potential as well as reducing environmental burden [14], which was investigated in a case study on consumers' clothing disposal behaviours [15]. For encouraging consumer behavior with more awareness of the sustainable clothing, the design of sustainable clothing should be normalized and the interventions should be adopted for upcycling, recycling and repair [16]. For reuse and recycling of textile products, the companies' strategies can adopt the uses of environmental friendly materials or apparel reuse [17]. Lack of technology, lack of material to recycle and lack of consumer awareness are the most important barriers to recycling apparel and apparel manufacturers should be encouraged to develop marketing strategies to ensure recycle more extensively [18].

\section{Product modularization for parts reuse}

Product modularization for parts reuse is a very effective method to apply the concept of reuse rather than the conventional material recycling [19]. Modular product concept selection was also applied to choose the best design for subsequent development with least risk to the enterprise [20]. Modular design was used in the assembly and disassembly of product components to support green life-cycle engineering [21]. Modular design can facilitate life-cycle material efficiency through component material reuse and such material reuse modularity must conform to the technical system modularity [22]. Modular design was combined with design for environment concept to reduce the potential negative environmental impacts as early as at the design stage of products. Design for assembly and design for recyclability were regarded as some specific methods for design for environment methodologies [23]. In this paper, design for disassembly and design for recyclability concept needs to be highlighted in apparel design for recyclability.

With the above situation as background, the objective of this paper is to propose a new method for apparel design and product structure modularization that rationalizes the reuse/recycle activities, and to show a new possibility for designing apparels with better reuse potential. Furthermore, a modular architecture framework of safety conscious decision support is proposed for apparel design and production. According to this framework, safety concern can be taken into consideration as early as at the stages of apparels; and based on the result of the analysis, the potential negative impact of safety on the apparel reuse and recycle can be maximally reduced.

A conceptual model of strategic choices for recyclable clothing system

\section{Starting point: practical implement process of SDPRAD model}

The MASA framework was practically implemented in four main steps: safety problem definition and research; product solution development and collaboration; recycling value creation and other recovery. In step (1), all apparel safety indicators found to be potential harmful to wearers were combined to determine which apparel attributes would be selected for prevention in the final recyclable clothing system. As an intermediate step (2), apparel attributes were modularized decomposition in clothing design and production for potential reuse based on product solution development and collaboration in clothing recycling system. The point to be stressed is that improvement should be prioritized to maximize safe control in the whole design and recycle triangle. In step (3), the recycling value creation process was implemented through turning apparel attributes into another apparel or other value product. In the last step (4), recovered clothing was disposed with some value recovery including secondary use after technical treatments. This conducting process could be illustrated in figure 1.

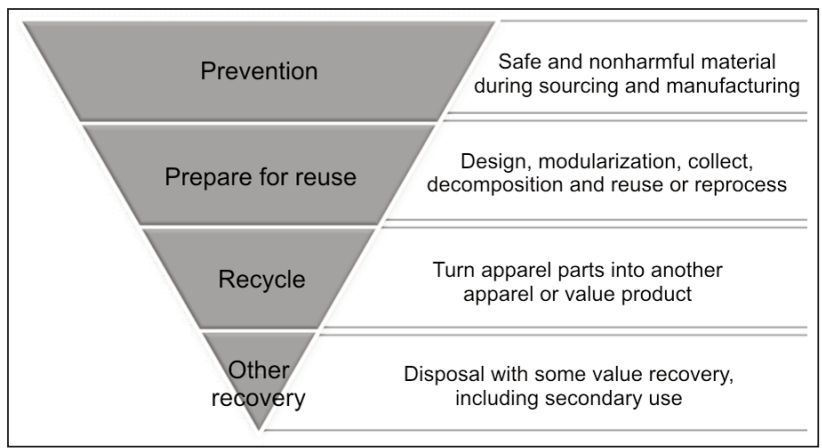

Fig. 1. The practical implement process for MASA framework 


\section{Modular apparel safety architecture framework}

Based on the literature review on apparel safety, apparel recycle/reuse and product modularization for reuse, we developed a modular apparel safety architecture framework (figure 2) as a lens to supervise apparel safety.

In our modular apparel safety architecture framework shown in figure 2, we decompose modular safety architecture into two levels: managerial and operational. The managerial-level decisions provide the guidelines for the apparel safety management and recycle, and integration of the operational-level business activities (figure 3). Next, we discuss the managerial and operational levels of our modular apparel safety architecture framework in more detail.

At the managerial level, we identify the supply chain management components in keeping with apparel safety attributes in integration of apparel recycle. These components describe the context in which enterprises introduce safety modularity and the guidelines for their business processes. The principles for sourcing, design, production, modularization and recycle guide the design, raw materials sourcing, processing, delivery and recycle technologies at the operational level. Next, we briefly interpret these principles with regard to apparel safety in our framework context.

The supply chain management components at the managerial level of the modular apparel safety architecture framework (figure 2) entail sourcing, design,

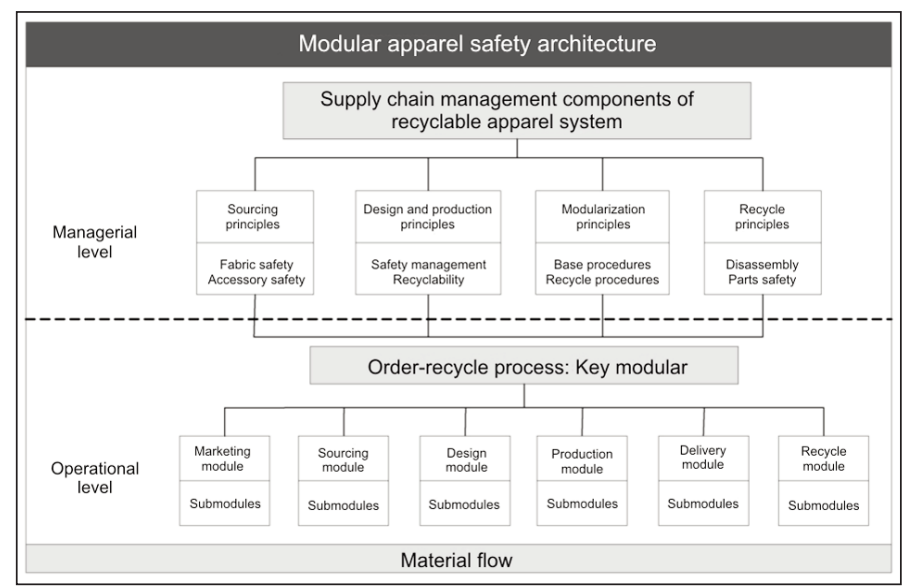

Fig. 2. MASA framework

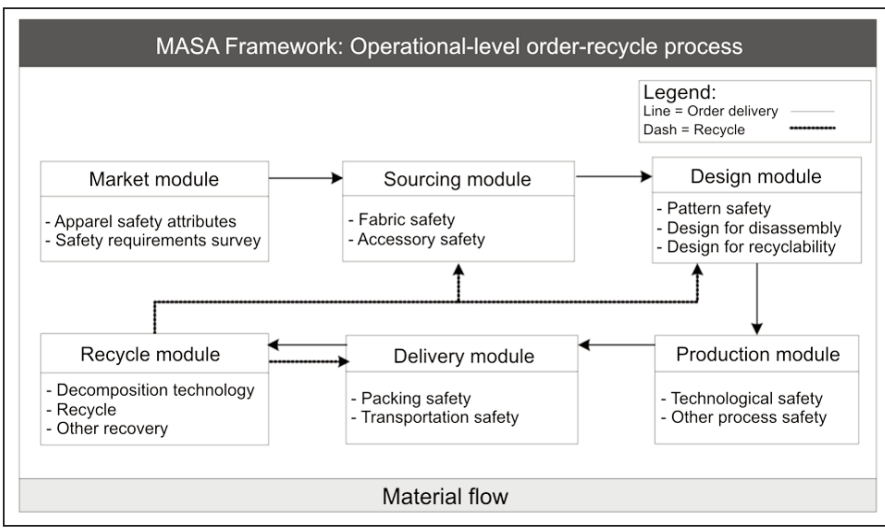

Fig. 3. Decomposing the operational level of apparel's order-recycle process production, modularization and recycle principles to implement a safe apparel order-recycle process. Sourcing principles include decisions on fabric safety and accessory safety. A multitude of fabric and accessory safety needs to be taken to account in the supply chain design to be able to offer safe raw materials for all target customers. At the core of a supply chain management of recyclable apparel system are design and production principles, which should provide the comprehensive and detailed apparel safety attributes management for conducting a material flow necessary for operating apparel recycle. The modularization principles decompose the apparel safety attributes into the order-recycle process, each of which can be further divided down to the basic procedures or recycle procedures. The recycle principles disassemble apparel into the lowest-level parts that can be define as various kinds of fabrics, lining, buttons and other accessories.

Based on the managerial-level decisions on sourcing, design, production, modularization and recycle principles in figure 2 , the resulting operational-level business activities provide more fine and specific contents of implementation to ensure apparel safety and recycle. The operational level of the modular apparel safety architecture framework is depicted in figure 3 . The operational-level order-recycle process comprises six lower-level key modules - market, sourcing, design, production, delivery and recycle and then further consists of the lowest-level components within each module.

The market module conducts a survey on apparel safety requirements in term of customers and their attributes in apparel. The sourcing module offers different sourcing options for fabrics and accessories. The design module is part of both the front-end apparel safety subprocess and the back-end apparel recycle subprocess internal to the firm. On the front end, the firm can confirm the design and material regarding the apparel safety and the apparel disassembly. The production module consists of technological safety management, including stonewashed jeans, breakage of thread and so on. Other process safety includes broken needles, scissors and other instruments that have potential risk to customers. The delivery module organizes its packing and transportation submodule in the delivery procedure. The recycle module's one option provide solutions for the customers for return the apparel, and the other option offer alternatives for the customers for not returning the apparel. The returned apparel limits the decomposition solutions to the apparel. The recycle subprocess flow is delineated by a dashed line in figure 3.

In short, a safe apparel order-recycle fulfillment process requires the integration of apparel safety requirements, design, production, delivery and recycles strategies. Next, we apply our modular apparel safety architecture framework to analyze the order-recycle processes for the case study children's clothing. 


\section{Case descriptions}

In this interpretive case study, we apply our modular apparel safety architecture framework shown in figure 2 and figure 3 to assist in the children's clothing design and production process. Our objective is to analyze the children's clothing orderrecycle process and summarize step by step the procedures, modules and safety attributes found at different operational level as well as their classification by procedure type into material, design, production and recycle options. The apparel safety information flows related to the order-recycle process are the focus of this paper, so we discuss them at length in the case descriptions.

A detailed summary of all procedures, modules, and safety attributes found in the case children's clothing order-recycle processes is available in figure 4 (by procedures) and table 1 (by Children's clothing safety attributes).
Modular children's clothing safety architecture: Operational-level order-recycle process

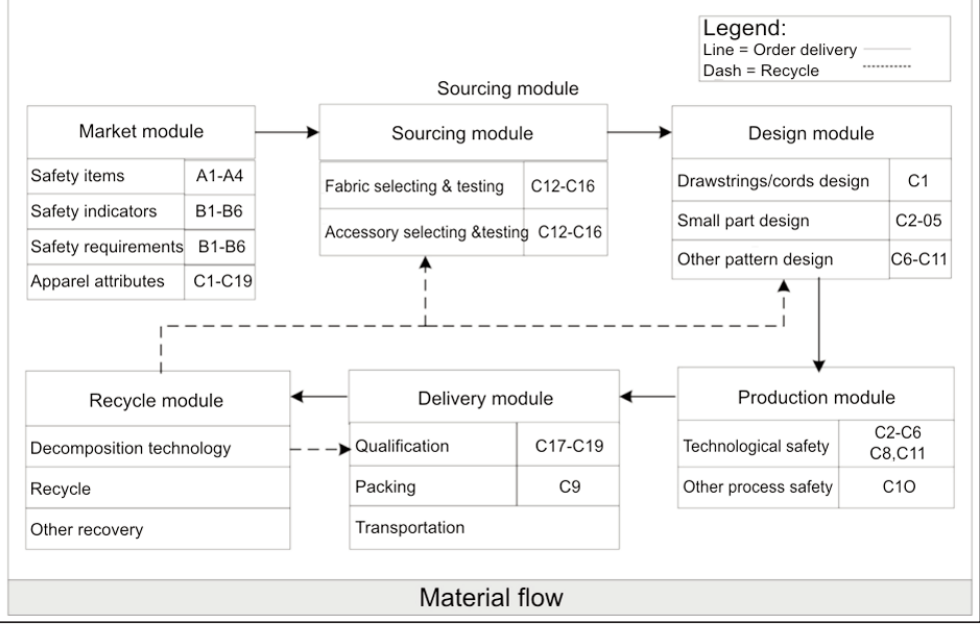

Fig. 4 Children's clothing order-recycle process: Operational Level Procedures and Submodules

In the market module, children's clothing safety demands and a wide of variety of children's clothing

\begin{tabular}{|c|c|c|}
\hline \multicolumn{3}{|c|}{ CHILDREN'S CLOTHING SAFETY INDICATORS AND THEIR ATTRIBUTES [4] } \\
\hline Items & Indicators & Children's clothing safety attributes \\
\hline \multirow[t]{3}{*}{$\begin{array}{l}\text { (A1) } \\
\text { Mechanical } \\
\text { Safety }\end{array}$} & $\begin{array}{l}\text { (B1) The length and use requirements of } \\
\text { drawstrings/cords }\end{array}$ & $\begin{array}{l}\text { (C1) drawstring, functional or decorative cord, elastic } \\
\text { cord, shoulder strap, halter neck cord, tied belt or } \\
\text { sash, stirrup and loop in children's garments }\end{array}$ \\
\hline & $\begin{array}{l}\text { (B2) The size, intensity, abrasion resistance } \\
\text { of small parts }\end{array}$ & $\begin{array}{l}\text { (C2) buttons, snaps and knots } \\
\text { (C3) zipper sliders, zipper pullers, pull tabs, rings and } \\
\text { toggles at the end of drawstrings } \\
\text { (C4) decorative small parts: pom-poms, appliqué, } \\
\text { heated patch, crochet tassel, small pieces of } \\
\text { fabric in the hem of clothing, spangles and beads } \\
\text { (C5) touch and close fastener, fringe, bows, feather, } \\
\text { label, badge, tabs }\end{array}$ \\
\hline & (B3) The use requirements of other parts & $\begin{array}{l}\text { (C6) hood, filling materials, sharp objects, neckties, } \\
\text { garment with integral feet, magnetic material and } \\
\text { embroidery } \\
\text { (C7) The dimension of open } \\
\text { (C8) Intensity and abrasion resistance of sewing thread } \\
\text { (C9) Materials and thickness of package bags } \\
\text { (C10) The instruments used in manufacture like } \\
\text { needles, sharp weapons(e.g. scissors), stone } \\
\text { washing or metal detection process } \\
\text { (C11) Seam security, seam strength, binding security } \\
\text { of snap, unrepaired thread end or floating }\end{array}$ \\
\hline $\begin{array}{l}\text { (A2) } \\
\text { Chemical } \\
\text { Safety }\end{array}$ & $\begin{array}{l}\text { (B4) Formaldehyde content, color fastness } \\
\text { to water, Acid color fastness to } \\
\text { perspiration, Alkali color fastness to } \\
\text { perspiration, Color fastness to dry } \\
\text { friction resistance, Color fastness to } \\
\text { saliva resistance, pH value, Abnormal } \\
\text { taste, AZO Dye }\end{array}$ & $\begin{array}{l}\text { (C12) fabrics: knots, bows, pom-poms, appliqué, } \\
\text { heated patch, crochet tassel, small pieces of } \\
\text { fabric and so on } \\
\text { (C13) buttons, fasteners, embroidery, zippers, spangles } \\
\text { and beads } \\
\text { (C14) sewing thread }\end{array}$ \\
\hline $\begin{array}{l}\text { (A3) } \\
\text { Flammable } \\
\text { Safety }\end{array}$ & (B5) Flammability requirements & $\begin{array}{l}\text { (C15) fabrics } \\
\text { (C16) padding }\end{array}$ \\
\hline $\begin{array}{l}\text { (A4) } \\
\text { External Safety }\end{array}$ & (B6) Qualification requirements & $\begin{array}{l}\text { (C17) qualification of product identification } \\
\text { (C18) fiber composition in label/tag } \\
\text { (C19) washing and nursing label }\end{array}$ \\
\hline
\end{tabular}


safety attributes are available through investigation and study on market research as well as related safety technical regulations and standards. Most of attributes come from raw materials or design process, while production and delivery procedure have safety attributes as well. These attributes exist in mechanical safety, chemical safety, flammable safety and external safety (table 1) [4]. The mechanical safety addressed the safety of drawstrings/cords, small parts and other possible sources in children's clothing. The chemical safety consists of residual poisonous and harmful substances in fabrics and supplementary material. The flammable safety is defined as failing no meet the flammable standards for fabrics or padding in children's clothing. The external safety means that qualification and authenticity of label/tag instructions in children's clothing.

Based on the survey and research results in market module, sourcing module and design module can be conducted immediately and must meet corresponding safety requirements that are available in the safety indicator inventory. In current industrial divisions, most apparel manufactures purchase fabrics or accessories from other industries or suppliers. To assist with prioritization of industry or company choices based on safety in their product offerings, an assessment of fabrics or accessories can be an insightful starting point and enable meaningful strategies for apparel manufacturer specializing chemical safety and flammable safety of materials. On top of this, it should be used in a safe pattern design for children's clothing, such as drawstrings/cords and small parts design, which is a major source of mechanical safety in children's clothing.

In production module, there are two kinds of safety management arouse attention, technological safety (i.e., intensity of small parts, abrasion resistance of sewing thread, seam security, seam strength, binding security of snap, unrepaired thread end or floating) and other process safety from instruments used in production process.

The delivery module includes labeling, packing, warehousing and transporting submodules. Labels/ tags (i.e., fiber composition, washing/nursing label) are attached to children's clothing are required authenticity and qualification. Packaging material testing and packaging form selecting require special attention and knowledge, such as thickness of package bags for suspension packaging or flat folding package.

The recycle module is very easy and flexible as well. Apparel can be returned to firms or apparel recycling bodies via various channels instructed in advance. Then, apparel returned is decomposed into various fabrics (i.e., cotton, polyester, hemp, wool and blended fabrics) and accessories (i.e., buttons, zippers, snaps, fasteners, labels, and ornaments) for further use in another sourcing module and design module. Another is worth mentioning, apparel returned can also be used as second-hand clothing.

\section{CONCLUSIONS AND FUTURE RESEARCH}

The MASA framework hopes to raise awareness about apparel choices and support safe designs and productions, environmentally preferable recycle and reuse. The MASA framework aims to change the way apparel are made, by providing that it's possible to produce safe, environmental apparels in ways that are safe, economic and sustainable. The devised MASA framework incorporates safety technical risks arising from involvement of textile and apparel with components, thus addressing the risk mitigation method for design concept selection from an enterprise point of view. Incorporating safety indicators of specific modules based on their contribution towards textile recycle and reuse is an important extension of this research. It is expected that the results of this work would be helpful for further research in understanding the dynamics behind recycle mechanism of the clothing in different environments. A possible future direction of research would be to incorporate specific aspects such as disassembly and recycle of textile and apparel in the existing formulation. The major benefits associated with the MASA framework are: assessing safety to support the effective exploration and penetration of recyclable clothing and reducing the risk of end products. There are barriers for further development of the recyclable clothing in China. The Chinese government plays a critical role to remove these barriers.

\section{ACKNOWLEDGEMENTS}

We thank China Postdoctoral Science Foundation (2014M561387) and Shanghai University of Engineering Science Foundation (2016-25) for providing the financial support to complete this work.

\section{BIBLIOGRAPHY}

[1] Gam, H.J., Cao, H.T., Farr, C., Heine, L. C2CAD: a sustainable apparel design and production model, In: International Journal of Clothing Science and Technology, 2009, vol. 21, no. 4, pp. 166-179.

[2] Chen L., Ding X., Wu X. Comparison of mechanical safety requirements and test methods of children's garments in Chinese and Euramerican standards, In: International Conference on Textile Bioengineering and Informatics Symposium, Shanghai, China, 28-30 May 2010.

[3] Chen, L., Wu, X., Ding, X. The definition of the defect for textiles and apparel defect in recall in China, In: International Conference on Advanced Textile Materials \& Manufacturing Technology, Hangzhou, China, 15-19 October 2008.

[4] Chen, L.H., Yan, X.F., Gao, C.C. Developing a practical evaluation framework for identifying critical factors to achieve apparel safety, In: The Journal of The Textile Institute, 2016, vol. 107, no. 12, pp. 1519-1532. 
[5] Wu, X.Y., Chen, L.H., Zhou, Y., Ding, X.M. Research in risk assessment for textile and apparel and propose a future research agenda with a conceptual framework, In: International Journal of Productivity and Quality Management, 2016, vol.17, no. 3, pp. 273-288.

[6] Wu, X.Y., Chen, L.H., Pang, S.H., Ding, X.M. Paratactic subjective-objective weighting methods and SVM risk assessment model applied in textile and apparel safety, In: International Journal of Quality \& Reliability Management, 2015, vol. 32, no. 5, pp. 472-485.

[7] Zhou, Y., Wu, X., Chen, L., Ding, X. Analysis of potential mechanical hazards of children's clothing based on fault tree method, In: International Conference on Textile Bioengineering and Informatics Symposium, Shanghai, China, 28-30 May 2010.

[8] Pang, S., Zhou Y., Ding X., Wu X. Application of TS fuzzy neural network in safety risk assessment of textile and apparel, In: Fuzzy Systems and Knowledge Discovery (FSKD) of Eighth International Conference, Shanghai, China, 26-28 July 2011.

[9] Taieb, A.H., Hammami, M., Msahli, S. , Sakli, F. Sensitising children to ecological issues through textile eco-design, In: International Journal of Art \& Design Education, 2010, vol. 29, no. 3, pp. 313-320.

[10] Gam, H.J., Cao, H.T., Farr, C., Bennett, J., Helmkamp, C., Farr, C. Application of design for disassembly in men's jacket: A study on sustainable apparel design, In: International Journal of Clothing Science and Technology, 2011, vol. 23, no. 2-3, pp. 83-94.

[11] Wang, W.Z., Wang, Y., Yu, S.L., Sun, L., Liu, J., Wei, X.M. Design for mutual transformation between outdoor wear and camping tent, In: International Journal of Clothing Science and Technology, 2014, vol. 26, no. 4, pp. $291-304$.

[12] Wang, W.Z., Yu, S.L., Wang, Q.Z., Luan, Y.B., Wang, J.Z., Wang, L.H., Guo, C.J. Study on eco-clothing with multiple style transformation in the background of cyclic economy, In: 4th International Conference on Manufacturing Science and Engineering, Dalian, China, 30-31 May 2013.

[13] Cuc, S., Iordanescu, M., Girneata, A., Irinel, M., "Environmental and socioeconomic sustainability through textile recycling", In: Industria Textila, 2015 , vol. 66, no. 3, pp. 156-163.

[14] Zurga, Z., Hladnik, A., Tavcer, P.F. Environmentally sustainable apparel acquisition and disposal behaviours among Slovenian consumers, In: Autex Research Journal, 2015, vol. 15, no. 4, pp. 243-259.

[15] Laitala, K. Consumers' clothing disposal behavior - a synthesis of research results, In: International Journal of Consumer Studies, 2014, vol. 38, no. 5, pp. 444-457.

[16] Harris, F., Roby, H., Dibb, S.Sustainable clothing: challenges, barriers and interventions for encouraging more sustainable consumer behavior, In: International Journal of Consumer Studies, 2016, vol. 40, no. 3, pp. 309-318.

[17] $\mathrm{Na}$, Y., Na, D.K. (2015), Investigating the sustainability of the Korean textile and fashion industry. In: International Journal of Clothing Science and Technology, vol. 27, no. 1, pp. 23-33.

[18] Larney, M., van Aardt, A.M. Case study: Apparel industry waste management: a focus on recycling in South Africa, In: Waste Management and Research, 2010, vol. 28, no. 1, pp. 36-43.

[19] Kimura, F., Kato, S., Hata, T., Masuda, T. Product modularization for parts reuse in inverse manufacturing, In: CIRP Annals - Manufacturing Technology, 2001, vol. 20, no. 1, pp. 89-92.

[20] Goswami, M., Tiwari, M.K. A predictive risk evaluation framework for modular product concept selection in new product design environment, In: Journal of Engineering Design, 2014, vol. 25, no. 1-3, pp. 150-171.

[21] Tseng, H.E., Chang, C.C., Li, J.D. Modular design to support green life-cycle engineering, In: Expert System with Applications, 2008, vol. 34, no. 4, pp. 2524-2537.

[22] Ji, Y.J., Jiao, R.J., Chen, L., Wu, C.L. Green modular design for material efficiency: a leader follower joint optimization model, In: Journal of Cleaner Production, 2013, vol. 41, pp. 187-201.

[23] Qian, X., Zhang, H. Design for environment: An environmental analysis model for the modular design of products, In: $11^{\text {th }}$ International Symposium on Electronics and the Environment/4 $4^{\text {th }}$ Electronics Recycling Summit, Boston, US, 19 May - 22 May 2010.

\section{Authors: \\ LIHONG CHEN ${ }^{1}$ \\ HONG YU2 \\ XINFENG YAN ${ }^{3}$ \\ Shanghai University of Engineering Science \\ ${ }^{1}$ School of Fashion Engineering, Department of Fashion Design and Engineering \\ 2 Shanghai Institute of Quality Inspection and Technical Research \\ 3 International Cultural Exchange School, Department of Business and Management \\ 333 Long Teng Road, 201620 \\ Shanghai, China \\ e-mail: Ihckxyy@163.com,79067192@qq.com, yanxf@dhu.edu.cn}

Corresponding author:

LIHONG CHEN

e-mail: Ihckxyy@163.com 


\title{
Redesign and upcycling - a solution for the competitiveness of small and medium-sized enterprises in the clothing industry
}

\section{REZUMAT - ABSTRACT}

\section{Reproiectare și reciclare - o soluție pentru competitivitatea întreprinderilor mici și mijlocii din industria de îmbrăcăminte}

\begin{abstract}
Lucrarea urmărește deschiderea unui nou domeniu de cercetare aplicabil întreprinderilor mici și mijlocii din industria de îmbrăcăminte, și anume, accentul pe designul noului produs prin creșterea eficienței utilizării și reciclării țesăturilor și o perspectivă asupra lanțului de valori care se concentrează pe etapa anterioara în cadrul acestuia. Obiectivul principal al lucrării este de a prezenta modul în care întreprinderile mici și mijlocii (IMM-urile) din industria de îmbrăcăminte pot obține un avantaj competitiv prin utilizarea unei abordări durabile. Acest studiu oferă soluții utile pentru înțelegerea proceselor de dezvoltare a produselor pentru industria modei cu scopul de a regândi, reutiliza sau recicla deșeurile în stadiul de producție. Se propune o noua conexiune între diferitele componente ale lanțului valoric: design, producție, marketing pentru a crea articole de modă, astfel încât, atunci când este posibil, aceste deșeuri să fie utilizate pentru a crea noi produse și se subliniază avantajele implementării acestei soluții. Producția durabilă poate fi o modalitate de a obține un avantaj competitiv. Această strategie poate avea succes prin integrarea lanțului valoric vertical, prin consolidarea departamentului de creație, a designului vestimentar și prin implicarea în marketing și vânzări. În industria de îmbrăcăminte, strategia de integrare a designului și vânzarea cu amănuntul pot duce la un proces de proiectare mai flexibil și, prin urmare, la o performanță ridicată a produsului.
\end{abstract}

Cuvinte-cheie: competitivitate, îmbrăcăminte, IMM-uri, sustenabilitate, reciclare

\section{Redesign and upcycling - a solution for the competitiveness of small and medium-sized enterprises in the clothing industry}

The paper aims to open a new field of research applicable to small and medium enterprises in the clothing industry, namely, the focus on new product design by increasing the efficiency of fabric use and recycling and a value chain perspective that concentrates on downstream in the chain. The main objective of this paper is to present how small and medium-sized enterprises (SMEs) in the clothing industry can achieve a competitive advantage by using a sustainable approach. This study provides useful solutions for understanding the product development processes for fashion to rethink, reuse or upcycle the waste in the production stage. We propose a better connection between different links of the value chain: design, production, marketing to create fashion items so when possible, this waste to be used to make new products and highlights the advantages of implementing this solution. Sustainable production can be a way of gaining a competitive advantage. This strategy can be successful by integrating the vertical value chain by strengthening the creative department, fashion design, and involvement in marketing and sales. In the clothing industry, the strategy of integrating design and retail can lead to a more flexible design process and, therefore, to an increased product performance.

Keywords: competitiveness, clothing, SMEs, sustainability, upcycling

\section{INTRODUCTION}

The textile and clothing sector in Romania is one of the key industrial sectors. The sector accounts for providing employment to a large of labor force in the country. It creates employment for 137000 employees and it contributes for about $11 \%$ of the Romanian's export revenues, at the second place after automotive industry, who held $40 \%$. Despite being rated among the top European exporters of textiles, over the past years, the Romanian textile and clothing industry has become less competitive in the global marketplace [1]. There are many reasons for this, including the liberalizing policies of the EU and WTO, the low profitability as well as the intense competition from low cost producing countries.

Romania's competitive advantage in clothing industry, reported to the European one, is mainly due to low-cost labour force. The clothing industry is considered to be one of the most labour intensive industry that focuses on creating, designing, manufacturing, marketing, consuming, supplying chain, trading and many other components of clothing, and its accessories as a whole. Considering this, labour costs have a major impact of the competitiveness in this market and their continued growth has negatively influenced Romanian competitiveness. Due to the concurrent factors impacting the clothing industry, Romanian producers can no longer compete based on cost alone.

Managers of the companies in clothing industries face major challenges to deal with the frequent problems that arise from ever changing operating conditions. They also have faced sophisticated strategic challenges that have to be addressed successfully if 
the firm will survive [2]. Under pressure of various unfavorable conjectural factors, Romanian clothing industry has traveled a restructuring period forced by the defensive adaptation type and characterized by reducing the market share and attempting to increase the productivity.

Clothing companies with strong domestic production, like Romanians, will need to rethink their strategies to focus on high value added activities, taking into account and embracing the new paradigm of circular economy and decreasing the production losses to be capable of improving their industrial competitiveness with trade balance and increase in productivity. Products with high added value can be achieved using advanced technologies or in the fashion sector through increased creativity and design that incorporate efficiently methods so as to minimize waste.

\section{The objectives of the study}

To address the purpose of the study and examine how small and medium-sized enterprises (SMEs) in the clothing industry can achieve a competitive advantage, the following objectives are proposed:

1. Analyze theoretical backgrounds and meanings of sustainability, competitiveness and competitive advantage.

2. Examine how clothing industry is affected by the ecological issues.

3. Examine how redesign and recycle can be a solution for the competitiveness of small and mediumsized enterprises (SMEs).

\section{Findings}

1. Sustainable production can be a way of gaining a competitive advantage. This strategy can be successful by integrating the vertical value chain by strengthening the creative department, fashion design, and involvement in marketing and sales.

2. In the clothing industry, the strategy of integrating design and retail can lead to a more flexible design process and therefore, in an increased product performance.

\section{Originality/value}

The paper opens a new field of research aplicable to small and medium enterprises in the clothing industry, namely, the focus on new product design by increasing the efficiency of fabric use and recycling and forming a value chain perspective that concentrates on downstream in the chain.

\section{THEORETICAL BACKGROUND:} COMPETITIVENESS, COMPETITIVE ADVANTAGE AND SUSTAINABILITY

Competitiveness can be assessed at different levels of aggregation: firm, industry, and country. Firm level analysis focuses on behaviours and performance of firms: using profitability, costs, productivity and market share as indicators of competitiveness

The literature on competitiveness indicates that the most feasible response is to 'upgrade' - to make better products, to produce them more efficiently or move into more skilled activities [3]. According to Porter (1990), competitiveness can be measured on the basis of productivity. Today, beyond financial or market-based indicators, performance should be measured in terms of how an organization manages its critical success factors like innovativeness, quality, ethical and ecological standing, social responsibility [4-6].

According to the generally established view of competitive process, a firm's performance is influenced by its competitive advantages. In its turn, the nature of such advantage results in one or more specific sources of competitive advantage which a firm controls. Concept of competitive advantage has a long tradition in the strategic management literature. Competitive advantage is a set of unique features of a company and its products that are perceived by the target market as significant and superior to the competition. Porter (1985) states that there are, in general, only two possible competitive advantages a firm may possess, a cost advantage or a differentiation advantage [7]. However, positive competitive outcomes can only be obtained by matching competitive strategy to available resources: for example, exceptional creative or scientific talent is useful for innovative differentiation, and economical production cost structures are needed to support sustained cost leadership [8].

In gaining competitive advantage, companies must develop new resources, capabilities, and activities because of the scarcity of natural resources [9]. Sustainability is not only instituting pollution controls or recycling programs when manufacturing products but it is about minimizing the harmful impact of the manufacturing processes on the environment at every stage, and it also brings new challenges to the companies, being a source of creativity and innovation.

Sustainability, as a business process, is the basis for low cost business strategies that include efficiency in every aspect of the planning process [10]. Ecological sustainability focuses on profitability through environmentally friendly operating processes. These processes may constitute a key basis for competitive advantage in the near future.

Managers begin to realize the fact that a large number of consumers prefer eco-friendly offerings, and that their businesses can score over rivals by being the first to redesign existing products or create new ones. To completely assume ecological production and its benefits, a company should adopt environmentally friendly policies and practices in the entire supply chain. In the design phase, it should use more eco-friendly products, planning for reuse and recycling: "Products, processes, and systems should be designed for performance in a commercial afterlife [11]. The manufacturing process needs to be more efficient, planning for optimum use of material and for reduction in waste production.

The literature has acknowledged the value of ecological sustainability and the internal capability of firms 
for its success. Several studies have been conducted in the past to investigate the impact of sustainable production on the overall organizational performance, financial rewards and competitiveness [12-13]. The nature of competition has changed due to the search for sustainability. Therefore, companies that are aware of this changing environment and set the sustainability as their mission will enjoy the advantages of first movers [14]. Practicing environmental sustainability encourages companies to look for new processes, technologies and introduce new products in order to overcome the challenges.

\section{ECOLOGICAL ISSUES IN THE CLOTHING INDUSTRY}

Growing competition in the clothing industry has forced companies to have serious attention towards the sustainability concept. For apparel manufacturers, involving in a sustainable production, finding and nurturing a competitive advantage through this can mean not only survival but also increased profit that can be successful in the long term.

In recent years, industrial development has achieved environmental improvements and has moved towards a smaller environmental impact. However, at the same time, production as well as consumption has increased by the same levels, which erodes the environmental benefits of the technological advances, i.e. the rebound effect [15].

Eco-materials and eco-efficiency have been top subjects that concern the textile industry in recent years. The strategy to waste management must give priority in the first place the prevention, in the second place recycling, reusing and revalorization and finally dispose waste. The clothing industry needs to find imaginative solutions to produce environmental improvements. The increasing amount of textile and clothing waste has led to the necessity of development of methods using the textile waste, i.e. reuse, recycling or redesign [16].

McDonough and Braungart, creators of the cradle to cradle concept, have advocated radical design innovations for perpetually circular material reuse [17-18]. Upcycling is one of the most sustainable circular solutions in the waste hierarchy, positioned between reuse and recycling, since upcycling typically requires little energy input and can eliminate the need for a new product [19]. Moreover, at the beginning of the $21^{\text {st }}$ century, several designers have made use of the concept of reuse and redesign in designing trendy products.

Reuse and recycling of materials, such as old clothes, manufacturing scraps and unsold items can be the material of sustainable fashion [20]. In contrast to reusing or recycling, upcycling uses available fabrics, clothes or other items to improve upon the original ones.

McDonough and Braungart offers a broad definition claiming that upcycling is "optimizing the materials, ingredients, and process pathways in such a way that waste is converted to raw materials for nature or some other industry" [21].

Murray (2002) [22] describes it as "not merely conserving the resources that went into the production of particular materials, but adding to the value embodied in them by the application of knowledge in the course of their recirculation. So, if one can add value - economic, intellectual, emotional, material - to a product through the process of reuse, it can be called 'upcycled" [23].

\section{AN UPCYCLING SOLUTION FOR THE MASS PRODUCTION}

Given the specificity of the products of clothing, usually upcycling in design and production has mostly been applied to unique products or for very small series by tailors or by small-scale fashion textile companies. Our aim is to apply upcycling in mass production more widely and find solutions for companies interested in finding a more environmentally sustainable solution to their textile waste problems. In order to implement the upcycling method, it is important to have an overview of the textile waste available because this is what dictates the item of clothing that can be created. By and large, textile waste can be divided into three groups: pre-consumer waste, production waste and post-consumer waste. All these types of textile waste can be used in fashion design. Each, however, requires a different technique when used as an input material

In this case, more approaches can be distinguished: the textile waste is used by the company that produces it (as production waste or pre-consumer waste) or the input material is obtained from other manufacturers.

For our example, we use the production waste because the input material for the production process is scraps from the apparel industry, which are generally small-sized, meaning that up to $25 \%$ of the material (depending on fabric design or proposed model) is wasted. Among the various processes of clothing production, cutting is the major area where fabric waste is generated. Proper investigation of the fabric losses during the cutting process can help the management to minimize material wastage. During the cutting process, two types of fabric losses occur, namely, marking loss and spreading loss. The marking loss arises due to the gap and the non-usable areas at places between the pattern pieces of a marker. Marker efficiency indicates the amount of marking loss. Spreading loss is the fabric loss outside the marker. The various fabric losses outside the marker can be broadly classified into different groups, namely ends of ply losses, ends of piece losses, edge losses, splicing losses, remnant losses, ticket length losses, etc. [24]. The waste is within the company so they don't have to be transported, stored, etc., the cutting efficiency is high because the material is placed in the batch and for their processing is not necessary additional investments. 


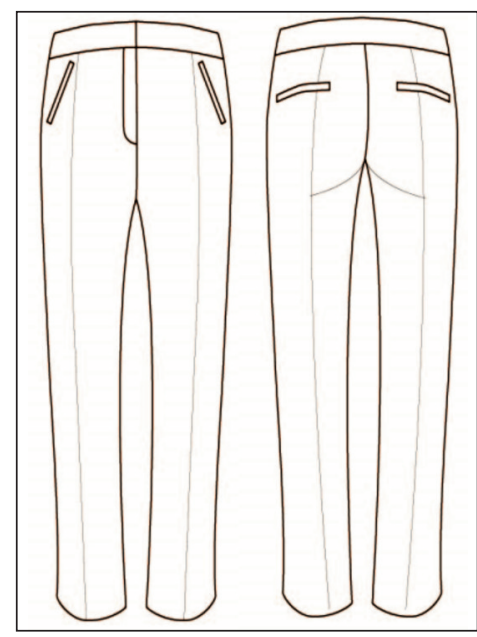

Fig. 1. Modell1. Men trousers (fabric: corduroy)

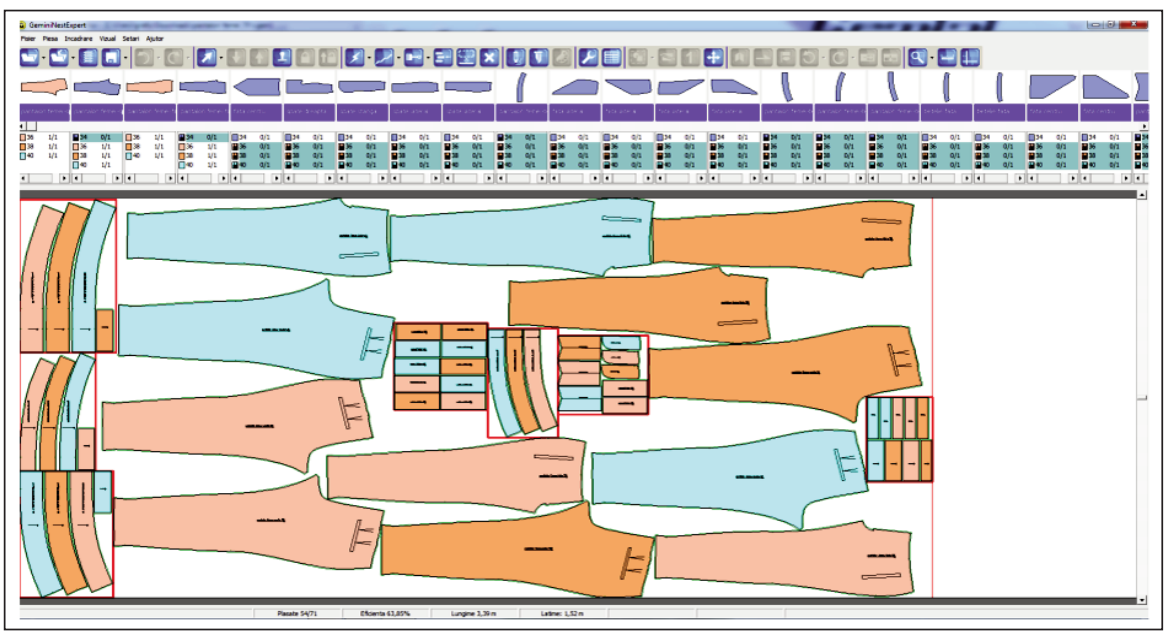

Fig. 2. The marker of the men trousers for 36,38 and 40 size
For the purpose of our paper, we prefer to present a solution to a real problem proposed by a company in Bihor County. The order which the company from Oradea has received was a lot of production of men's pants made of corduroy (model of figure 1), for which cutting efficiency accepted by the beneficiary was $60 \%$.

In order to solve the problem, we adopted two sets of measures: The first step we used was to minimize the fabric wastage so as to prepare the most efficient marker. The marker efficiency is usually influenced by the fabric characteristics (differences in face and back, lengthwise directionality, crosswise symmetry, need for matching the fabric design, length of design repeat, and fabric width); shapes of pattern pieces, fabric utilization standards and marker quality [25].

Efficiency of marker depends on how tightly the pattern pieces are fit together in the marker. Here, total surface area of the pattern pieces is compared to the total area of the marker for calculating the percentage of fabric that is used.

Marker efficiency is usually influenced by fabric characteristics (differences in face and back, lengthwise directionality, crosswise symmetry, need for matching the fabric design, length of design repeat, and fabric width); shapes of pattern pieces, fabric utilization standards and marker quality.

At first, with the help by the CAD system Gemini Nest Expert software, pattern for 36,38 and 40 size has been made. The marker width is $1,520 \mathrm{~m}$ and marker length is $3,383 \mathrm{~m}$. To increase the fabric utilization percentage we use three garment sizes in the same marker and include in the marker both large and small pieces. Smaller pieces can often be nested with larger pieces. Grain line markings determine the placement of the pattern relative to the warp yarns in woven or wales in knit fabrics. Pattern for different parts of the 36,38 and 40 size of the corduroy trousers has been shown in figure 2. The area of each pattern piece is determined by the computer. The area in between the pattern pieces, which is not used by garment parts, is waste.
Because of the above-mentioned restrictions, even if we provided a combined framing of several small sizes $36,38,40$, we could not get a higher efficiency of $63.85 \%$, which are within the limits imposed by the customer $(60 \%)$, but is unsatisfactory in terms of the high amount of waste.

Further, to use the remains fabric that covers the area in between the trousers pattern pieces, we have created a new product, a skirt design (figure 3), that diminishes and upcycled the production waste results in the production of corduroy trousers. For to reduce $\%$ waste, which in this case would be $36.15 \%$, we made a new marker in which we put in the same area the parts of skirt - size 34 - skirt made of many small parts - figure 3 .

By introducing a new product in the presented marker, we managed to increase the marker efficiency from $63.85 \%$ to $75.64 \%$. Moreover, after marketing the new product, the economic efficiency of the firm increases. As the fabric is the major raw material in a garment, the saving of very little amount of fabric per garment or reuse is efficient and it can also save money, which can increase the profit of the company substantially.

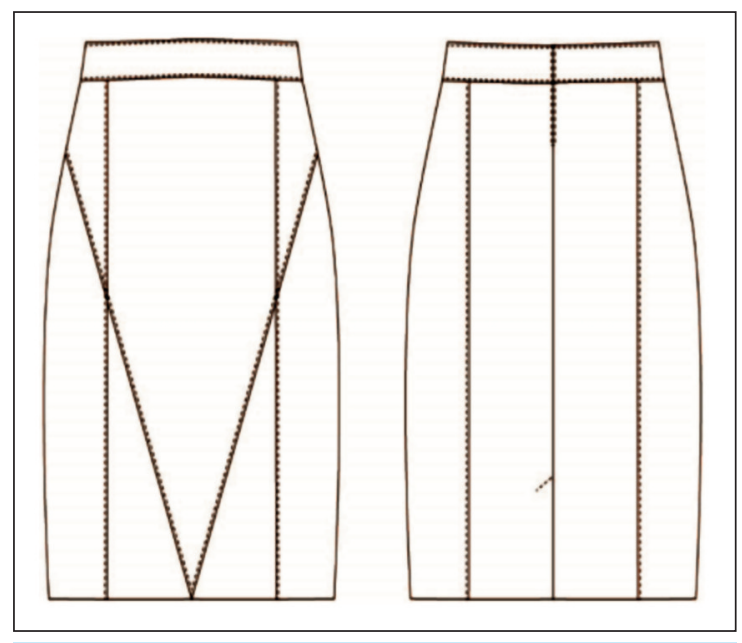

Fig. 3. Modell 2. Skirt (fabric: corduroy) 


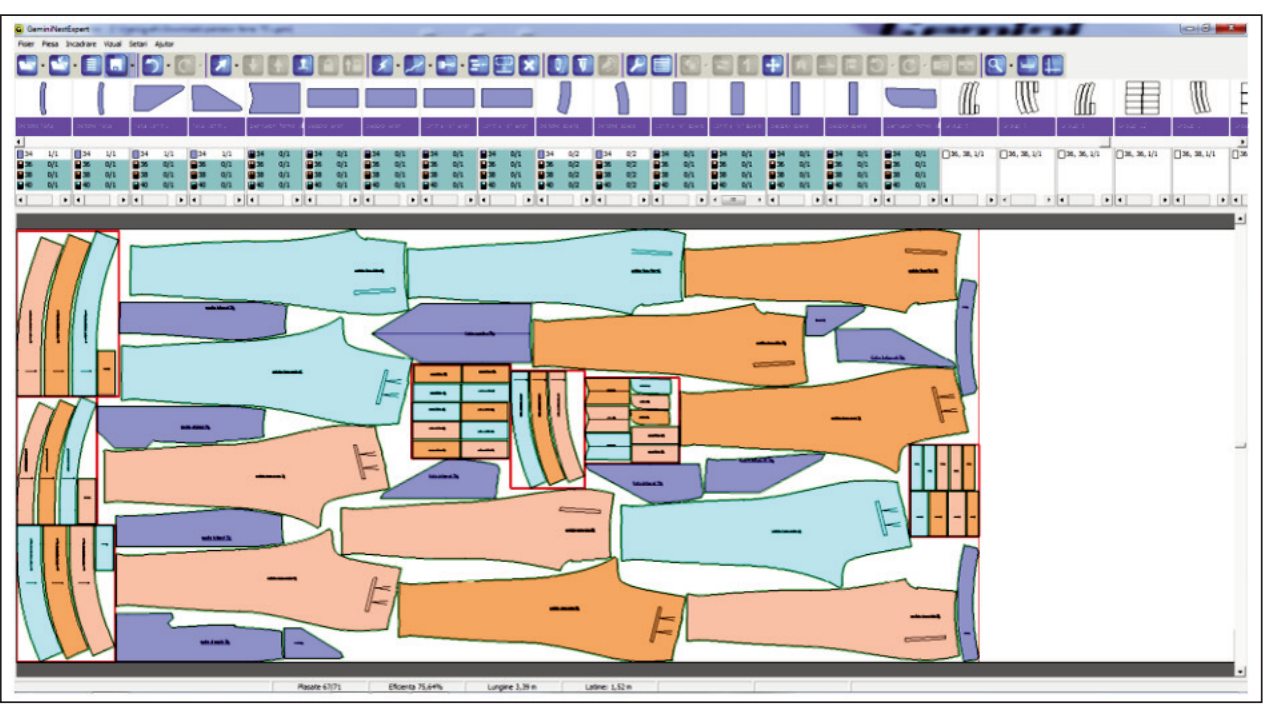

Fig. 4. The marker of the men trousers for 36,38 and 40 size and skirt for 34 size
- They have to pursue the market and promote their own products through a marketing policy that attract eco-sensitive customers.

Among the benefits of applying this solution there is one that stands out - reducing the wastes resulting from the cutting operation and the development of competitive products. This is a result of the fact that the raw materials incorporated in these comes from If in the free spaces that remained after fitting the parts from initial order (trousers in our case) not all the parts of the skirt can be fitted (as shown in the figure 4) they may be placed on another marker that will serve for cutting the parts of some products made of the same material or another one compatible with the first thus obtaining an increase of fitting efficiency.

\section{CONCLUSION}

This study provides useful solutions for understanding the product development processes for fashion to rethink, reuse or upcycled the waste in the productions stage.

Reduction of the waste and the making the new products does not require too much effort and expenditure. However, it is necessary that small and medium enterprises should consider the following:

- They must be concerned about modernization and purchasing suitable software,

- They have to encourage the creative activity by employing fashion designers who are able to create new models and make different combinations of materials, the waste - for which the company does not have to pay.

Moreover, the company will reduce waste management costs which can be reflected in the sale price of the company products or in the company profit. Other benefits could result from the company's image who can promote eco-friendly products and thus they can win additional market shares - knowing that today more and more buyers are sensitive to environmental issues.

Starting or shifting to this new business offers a potential economic benefit of upcycling. Alongside the economic benefits, managers have to realise the importance of the effective implementation of environmental strategies as a critical factor for becoming competitive in the global market in the future. The companies can create and propose more imaginative, courageous fashion using sustainable materials. Sustainable production can be a way of gaining a competitive advantage. In the clothing industry, the strategy of integrating design and retail can lead to a more flexible design process and, therefore, in an increased product performance.

\section{BIBLIOGRAPHY}

[1] Tripa, S., Cuc, S., \& Oana, I. (2016). Revealed comparative advantage and competitiveness in Romanian Textile and Clothing Industry/Avantaj comparativ aparent si competitivitate în industria de textile si de confectii din România., In: Industria Textila, 2016, 67(5), p. 338.

[2] Girneata, A., Giurgiu, A., Dobrin, O. C., Popa, I., Popescu, D. I., Cuc, S., \& Voicu, L. (2015). Performance management practices in Romanian textile and clothing companies/Practici de management al performantei în companiile românesti de textile si confectii., In: Industria Textila, 2015, 66(2), p. 108.

[3] Kaplinsky, R. (2000). Globalisation and unequalisation: What can be learned from value chain analysis?. In: Journal of development studies, 37(2), pp. 117-146.

[4] Porter M. E. (1990), The competitive advantage of nations, Harvard Business Review, 68(2), pp. $73-93$.

[5] Boynton, A. C., \& Zmud, R. W. (1984). An assessment of critical success factors. In: Sloan management review, 25(4), pp. 17-27.

[6] Depperu, D., \& Cerrato, D. (2005). Analyzing international competitiveness at the firm level: concepts and measures. In: Quaderni del Dipartimento di Scienze Economiche e Sociali, Università Cattolica del Sacro Cuore Piacenza, 32, 2007-2013. Available online http://dipartimenti.unicatt.it/dises-wp_azzurra_05_32.pdf 
[7] Porter, M.E. (1998). Competitive advantage: creating and sustaining superior performance: with a new introduction. The Free Press, New York.

[8] Barney, J. (1991). Firm resources and sustained competitive advantage. In: Journal of management,17(1), pp. 99-120.

[9] Rodriguez, M.A., Ricart, J.E. \& Sanchez, P. (2002). Sustainable development and the sustainability of competitive advantage: A dynamic and sustainable view of the firm. In: Creativity \& Innovation Management, 11 (3), pp. 135-146.

[10] Stankevičiūtè, E., Grunda, R., \& Bartkus, E. V. (2012). Pursuing a cost leadership strategy and business sustainability objectives: Walmart case study. In: Economics \& Management, 17(3), 1200-1206. Available online http://doi.org/10.5755/j01.em.17.3.2143

[11] Anastas, P. L. \& Zimmerman, J. B. Through the 12 principles of green engineering. In: Environmental Science and Technology, 2003, March 1, pp. 95-101A.

[12] Kurapatskie, B., Darnall, N., Which corporate sustainability activities are associated with greater financial payoffs?, In: Business strategy and the environment, vol. 22, no. 1, pp. 49-61, 2012.

[13] Cuc, S., lordanescu, M., Gîrneata, A., \& Irinel, M. (2015). Environmental and socioeconomic sustainability through textile recycling/Sustenabilitatea de mediu si socioeconomica prin reciclarea textilelor. In: Industria Textila, 66(3), p. 156.

[14] Nidumolu, R., Prahalad, C.K. \& Rangaswami, M.R. (2009). Why sustainability is now the key driver of innovation. In: Harvard Business Review, 87 (9), pp. 56-64.

[15] Throne-Holst, H., Stø, E., \& Strandbakken, P. (2007). The role of consumption and consumers in zero emission strategies. In: Journal of cleaner production, 15(13), pp. 1328-1336.

[16] Dissanayake, G., \& Sinha, P. (2015). An examination of the product development process for fashion remanufacturing. In: Resources, Conservation and Recycling, 104, pp. 94-102.

[17] Braungart, M. \& McDonough, W., 2002. Cradle to cradle. Remaking the way we make things. Vintage, New York.

[18] McDonough, W. \& Braungart, M., 2013. The upcycle: Beyond sustainability - Desining for abundance. North Point Press, New York:

[19] Szaky, T., 2014. Outsmart waste. San Francisco, CA: Berrett-Koehler Publisher, Inc.

[20] Fletcher, K. Sustainable fashion and textiles, In: Design Journeys, Earthscan: London, UK, 2008.

[21] McDonough, W. \& Braungart, M. (2013). The upcycle: Beyond sustainability-designing for abundance. New York, New York: North Point Press.

[22] Murray, R. (2002). Zero waste. London, UK: Greenpeace Environmental Trust. Available online http://www. zerowasteeurope.eu/wp-content/uploads/2011/04/zero-waste-by-robin-murray.pdf

[23] https://library.ndsu.edu/repository/bitstream/handle/10365/23189/Meyers_Designing $\% 20$ and $\% 20$ Selling $\% 20$ Recycled\%20Fashion.pdf?sequence=1

[24] Pamuk, O., \& Yildiz, E. Z. (2016). A study about parameters affecting the marker plan efficiency. In: Journal of Textile \& Apparel/Tekstil ve Konfeksiyon, 26(4).

[25] Dumishllari, E., Guxho, G.,( 2015), Impact of marker on cut plan in garment production, In: International Journal of Innovative Research in Science, Engineering and Technology, vol. 4, I. 8, pp. 7377-7381.

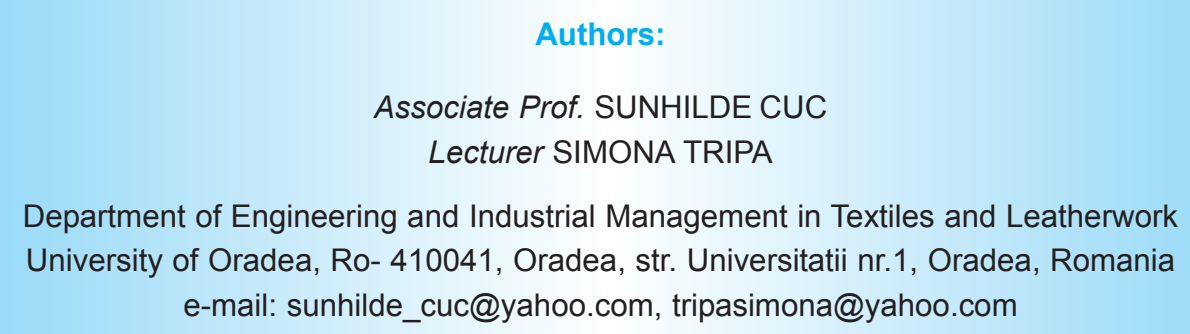

Corresponding author:

SIMONA TRIPA

e-mail: tripasimona@yahoo.com 


\section{Change in Textile and Clothing Industry}

DOI: $10.35530 / I T .069 .01 .1449$

\section{REZUMAT - ABSTRACT}

\section{O schimbare în industria textilă şi de îmbrăcăminte}

În mod tradițional, industria textilă și de îmbrăcăminte a fost cunoscută pentru schimbările sale graduale, dar mediul de afaceri global actual creează premisele pentru mai multe schimbări organizaționale perturbatoare. Managementul schimbării îi ajută pe oameni să treacă peste schimbările structurale într-o manieră pozitivă și eficientă. Întreprinderile mici și mijlocii din industria textilă și de îmbrăcăminte se confruntă cu anumite provocări - noi tehnologii care necesită investiții mari, arbitrajul de relocare cu costurile forței de muncă, protecționismul industriei regionale, preferințele volatile ale consumatorilor, nevoia de noi abilități manageriale etc. - toate acestea necesitând o reechilibrare a concentrării manageriale, de la excelența operațională la excelența strategică și de management al schimbării. Un model de management al schimbării, cu o disciplină de implementare asociată și atenția acordată tendințelor pieței mondiale, reprezintă o necesitate pentru actualii manageri care activează pe piața produselor textile și de îmbrăcăminte.

Cuvinte-cheie: industria textilă, îmbrăcăminte, managementul schimbării, model de schimbare

\section{Change in Textile and Clothing Industry}

Traditionally, Textile and Clothing Industry has been known for its incremental changes but the current global business environment creates the premises of multiple organizational disruptive changes. Change Management helps people to transition structural change in a positive and efficient manner. Small and medium enterprises in Textile and Clothing Industry face a particular set of challenges - new technologies requiring high investments, relocation arbitrage on labor costs, regional industry protectionism, volatile consumer preferences, need for new managerial skills etc. - all these demanding a rebalance of managerial focus from operational excellence to strategic and change management excellence. A Change Management Model, with associated implementation discipline and attention to global market trends, represents a necessity for current managers active in Textile and Clothing Market.

Keywords: textile industry, clothing, change management, change model

\section{INTRODUCTION}

Business environment is in a continuously changing process. At macro level, local or regional economic crises are emerging, trends as deregulation, globalization and advances in information systems and technologies are impacting the economic environment, population ages, governmental regulations are changing, social movements and terrorism arise, international agreements are changing, nature is negatively affected by enterprises' activity and so on. At micro level, competition is intensifying due to market's globalization; consumers' requests become harder to satisfy, as their requests and needs are evolving together with their knowledge and access to information and latest developments in e-commerce etc. Internally, also, enterprises confront with a series of challenges - new strategies are adopted in order to adapt to external environment's requests, new technologies are implemented, know how is developed, managers become more professional and informed, new market segments are addressed, changes in leadership take place and so on.

In European textile and clothing industry $99 \%$ of enterprises are small or medium (SMEs) [1]. Compared to large enterprises, SMEs have very specific environmental threats, as limited material, financial, informa- tional, human and managerial resources, lower negotiation power, higher interest rates available etc. Even though they are permanently ready to change in order to grow, usually SMEs have little information about the way to approach change effectively.

Change Management increases the efficiency of change projects, inducing employees' acceptance and involvement. After a complex research of Change Management theory and models, as well as of T\&C industry's specificities TexChange, a customized change management model, was drafted. TexChange is a straightforward but efficient fivesteps model, perfectly adapted to SMEs, to ensure the success of organizational change processes.

\section{CHANGE IN TEXTILE AND CLOTHING INDUSTRY}

For a long time, the main factors influencing change in Textiles and Clothing Industry (T\&C) have been (2) "the changing habits and needs of consumers" and the "short life cycles due to fashion trends", fashion being practically synonymous with change [3]. Currently, even trends in fashion started to be influenced by macro and micro factors, as volatility of global economy, China's trading and production policies, new technologies in the supply chain etc. [4]. 
However, Textile and Clothing Industry (T\&C) is larger than fashion, including textiles' value chain (natural and man-made fibers, yarns and fabrics) and clothing' value chain (finished fabric, clothes, home textiles, technical textiles etc. - sold retail or B2B), each being affected by another set of change factors [5].

For instance, new technologies are developed to improve T\&C manufacturing and trade, in order to: (1 respond to fashion trends (new types of fabric, new dyeing techniques etc.), ensure the efficiency of mass production (computer-aided design, cutting, sewing etc.), respect ecologic trends (eliminating or rationalizing the use of the toxic chemicals needed in production process, recycling fibers as raw materials, rationalizing transportation etc.), adapt to increasingly sophisticated shoppers (selling online, offering added value through quality or price, ensuring a long term relationship etc.) and create new products for new needs (waterproofed fibers, no iron fabrics, smart fabrics etc.) [1-5].

Innovation is the key of success for textiles' companies, just as in other economic field [6]. This is why it is expected a significant growth on global smart textiles, like military smart textiles that include GPS and wireless weapons, architecture smart textiles that generate energy, sport smart textiles that monitor speed, distance and pulse rate, fashion smart textiles that emit lights, medical smart textiles that monitor health conditions etc. [7].

Although, traditionally, innovation in textile sector has been more incremental than disruptive, as "technologies were built closely on previously available technologies", the current market developments seem to change the situation [8].

A research of McKinsey \& Company showed that specialists consider 2016 as "one of the hardest years the fashion industry has ever experienced. Across all market segments, product categories, and geographies, the industry has been shocked by tremors in the global macroeconomic and geopolitical sphere, large scale shifts in consumer behavior, and intensifying business pressures to produce more for less - less time, less money, and less effort" [4]. The most important challenges identified by T\&C executives in this study are: Dealing with volatility, uncertainty and shifts in the global economy; Competition from online players and decreasing foot traffic; Speed of change in consumer preferences; Margin erosion due to discounting; Sales and profitability growth; Speed of market and fashion cycle. These trends offer an image of a very active and modern industry, influenced by the disruptive economic, technologic and social environment.

Globalization offers to T\&C enterprises both opportunities - to collaborate beyond national and even regional borders, and threats - especially related to a more challenging competitive environment [9]. These are possible due to formation of complex global value chains. "Value chains are flexible constructions that continuously adapts to market conditions, at an extremely rapid process of change" [10] and includes activities needed to bring a product "from conception through different phases of production (...) to delivery to final consumers" [11].

The geographic distribution of T\&C global value chain depends on factors as workforce's specialization, production costs (as water, energy, technologies, wages, transportation, interest rates etc.), negotiation power etc. For instance, comparing manufacturing costs in low cost countries, can be seen that while Eastern European countries have lower energy costs, they practice higher wages and interest rates (delta $\mathrm{Y}-\mathrm{o}-\mathrm{Y} \%$ ) than other countries as India, Sri Lanka and Pakistan, with higher energy costs and lower wages and interest rates [11]. Therefore, cost efficiency of each value chain element needs to be carefully analyzed by interested companies.

Somehow, contrary to globalization policies, after USA's tendency to relocate T\&C production from Asia to its own territory, UE initiated reshoring and recovery policies, ensuring this way "creation of European chains and vertical integration" [10]. UE's main strength, which helped it to become the first supplier of T\&C in the world in 2016 [12], is having on its territory "each step of the value chain - from fiber through fabric to ready-to-use product" [5]. Romanian Textiles Industry has also all levels of the value chain, but not equally developed or growing with the same speed. For instance, "synthetic or man-made filaments" is the largest segment of T\&C Romanian Industry (41\% in 2015), but "knitted or crocheted clothing and accessories", one of the traditional Romanian products segments, recently grew the most $(26 \%$ in 2010-2015), having an important share in the industry $(14 \%$ in 2015$)$ [13].

It is obvious, therefore, that change is impossible to avoid for any enterprise, including T\&C. As a response, we see an increased interest in management of supply chains in order to achieve a quick response and to reduce lead times. There are two main management concepts developed with this purpose: lean supply management reduces waste (raw materials or time), while agile supply is market sensitive, helping the company to react to factors from "a constantly changing and highly competitive business environment" [14-16]. Change Management, also, proved itself useful to companies in the whole world, in all industries, in approaching efficiently the continuously changing environment.

\section{CHANGE IN ROMANIAN TEXTILE AND CLOTHING INDUSTRY}

In 2015, European Union's T\&C turnover was $169 \mathrm{Bn}$ euro, realized by 174.000 companies and 1,7 Mil employees, while Romania's T\&C turnover was 3,6 Bn euro, realized by 6111 companies with 0,17 Mil employees [1,13]. The fact that Romania is the second employer in UE's textile and fashion sector $(10 \%$ of EU's employees) is not consistent with 
Romanian's share in European T\&C turnover (only $2,1 \%)$. This discrepancy suggests a low level of efficiency and added value in Romanian T\&C industry [1] Considering the Index of turnover, the whole European Textile \& Clothing Industry contracted significantly in 2008-2009 and started to grow back in 2010 [17]. Romanian T\&C had a good evolution regarding Index of turnover, moving up from the last place of EU countries in 2007 ( $89 \%$ of 2010 value) to the $3^{\text {th }}$ place in 2015 (147\% of 2010 value) and $2^{\text {th }}$ in 2016 (155\% of 2010 value, growth exceeded only by Poland with 186\%) [17].

Romanian competitive advantage on this market is the low-cost labor force, average net nominal earnings per employee being just 292 euro/month or 3 euro/hour, but "analyzing the top, considering value added per employee, Romania is placed on second to last place, before Bulgaria" [10, 17]. In 2014, Gross value added by Manufacture of textiles, wearing apparel and leather products represented $2,23 \%$ of total Romanian Gross value added. Nevertheless, labor productivity per employee decreased, during 2010-2015, with $18 \%$ in textiles and $1 \%$ in wearing apparel [13]. Industry's productivity can also be expressed by metrics such as Turnover per employee (20.476 euro/employee) and Turnover per company (58.397 euro/company) [13].

It is hard to believe that Romanian T\&C industry might improve its productivity, considering the decreasing share of investments in T\&C turnover (only $4 \%$ in textiles and $3 \%$ in wearing apparel in 2015 , compared to $7 \%$ and, respectively, $6 \%$ in 2013) and the low share of research and development personnel (only 0,42\% from total number of employees in 2015) [13]. The benefit of external investments determined by the low-cost labor force (compared to other European countries) can be easily counteracted by the low productivity of labor caused by lack of investments in new production and management technologies.

Romania has lower wages and interest rate (delta $\mathrm{Y}-\mathrm{o}-\mathrm{Y} \%)$ than other European countries, but higher than some low-cost production countries, as India, Sri Lanka and Pakistan [11]. In this context, the general tendency to relocate $T \& C$ production on European territory is favorable to Romania [5, 10, 13]. Even so, Romanian Balance of Trade for T\&C industry decreased constantly in 2010-2015, reaching a 65 Mil euro trade deficit in 2015 [13]. It is interesting to observe the comparative evolution of Romanian and EU-28 Trade Balance $[13,17]$. While EU-28 Trade Balance is lowering slowly (-27\% in 2012-2015), Romanian Trade Balance is dropping abruptly (almost four times in 2012-2015). This trade deficit is a serious alarm signal for an industry that have a high potential for Romanian economy (2,23\% of total Romanian Gross value added, $2^{\text {nd }}$ employer in European T\&C etc.).

Sometimes the trade deficit is caused by increasing imports, determined by the improvement of domestic economy, but this does not seem to be the case, since Romania has the lowest average European household consumption for textile and clothing - 100 euro (next to Bulgaria, Hungary, Macedonia and Serbia) compared to European average of 600 euro [17]. This, in spite of the fact that local manufacture of wearing apparel is better represented than manufacture of textile in Romanian market: the turnover and net investments are almost double, the average number of employees is fourth times higher etc. [13]. Since organizational and market changes are often determined by the competition level, it is useful to analyze it. Evaluating the competition between Top 10 Apparel Brands in the world and Romanian market can be done with few indicators. While HirschmanHerfindahl Index is usually used to measure market concentration, it weights in favor of larger companies. Entropy Index, using market shares as the weight, relatively increases the importance of small competitors [18]. This is why both indicators have been used. Both showed a very intense competition on apparel market (table 1).

The competition in Romania is just as strong as at global level. It is interesting to observe that some of the Romanian brands are effectively competing with global brands on national market, proving both that Romania is a good competitor and that on this market the entry barriers are still low, in spite of technological progress.

A highly competitive market determines its constituents to aspire to change in order to differentiate themselves and attract a larger part of the market. The fact that Top 5 companies in Romanian T\&C industry are covering only $12 \%$ of their market also reflects the highly competitive environment [13].

The circumstance that many enterprises in T\&C are of small or medium size (99\% of European T\&C are SMEs), according to Euratex [1], only increases the difficulties they are facing - investments are more difficult, managerial skills are sometimes low, their negotiating power with large companies is low etc. Regardless their size, companies on this competitive market need strong, innovative, strategic management, as Change Management, in order to be successful in a continuously changing environment.

\section{TEXCHANGE - A CHANGE MANAGEMENT MODEL FOR TEXTILE AND CLOTHING SMALL AND MEDIUM ENTERPRISES}

Considering the previously described business environment, change is inevitable. Talking about this, Filiep Liebeert, President of Euratex (European Apparel and Textile Confederation), emphasized the main directions of change in T\&C industry: moving from commodity to specialty on a particular market segment, moving in a different segment of manufacture (from apparel to textiles, to technical or highspec areas), moving toward delocalizing its activities to lower labor costs, or moving toward job cuts and 


\begin{tabular}{|c|c|c|c|c|}
\hline \multicolumn{2}{|c|}{$\begin{array}{l}\text { Global market } \\
\text { (million euro) }\end{array}$} & \multicolumn{3}{|c|}{$\begin{array}{c}\text { Romanian market } \\
\text { (million euro) }\end{array}$} \\
\hline Christian Dior S.A. & 34,944 & \multicolumn{2}{|c|}{ H\&M Hennes\&Mauritz } & 172.9 \\
\hline Nike & 25,704 & \multicolumn{2}{|l|}{ Roumasport } & 139.4 \\
\hline $\mathrm{H} \& \mathrm{M}$ & 18,060 & \multicolumn{2}{|l|}{ C\&A Moda Retail } & 85.2 \\
\hline Zara & 13,356 & \multicolumn{2}{|l|}{ Pepco Retail } & 76.3 \\
\hline Adidas & 12,852 & \multicolumn{2}{|l|}{ NY'er Romania } & 53.3 \\
\hline GAP & 11,592 & \multicolumn{2}{|c|}{ Peeraj Brands International } & 52.2 \\
\hline Kering & 11,172 & \multicolumn{2}{|c|}{ Peek \&Cloppenburg } & 47.5 \\
\hline Ralph Lauren & 6,384 & \multicolumn{2}{|l|}{ FF Group Romania } & 42.3 \\
\hline Hermes & 4,536 & \multicolumn{2}{|c|}{ Takko Fashion International } & 31.2 \\
\hline Levi's & 4,032 & \multicolumn{2}{|c|}{ LPP Romania Fashion } & 25.9 \\
\hline \multicolumn{2}{|c|}{$\begin{array}{l}\text { Source: http://fashion2apparel.blogspot.ro/2017/01/top-apparel- } \\
\text { brands-world.html }\end{array}$} & \multicolumn{3}{|c|}{ Source: http://www.topfirme.com/caen/4771/cifra-de-afaceri/ } \\
\hline \multicolumn{5}{|c|}{ Estimated competition intensity } \\
\hline & \multicolumn{2}{|r|}{ Global } & \multicolumn{2}{|c|}{ Romanian } \\
\hline $\begin{array}{l}\text { Hirschman-Herfindahl Index } \\
H=\sum_{i=1}^{N} s_{i}^{2}\end{array}$ & 0,14 & Very intense & 0,14 & Very intense \\
\hline $\begin{array}{l}\text { Entropy Index } \\
H=\sum_{i=1}^{k}\left(p_{i} * \log _{2} \frac{1}{p_{i}}\right)\end{array}$ & 0,91 & Very intense & 0,92 & Very intense \\
\hline
\end{tabular}

closure. Regardless the direction of change an organization is taking, a good management of this process is essential.

Many enterprises started using Project Management to handle change processes toward organization's goals. Complementary to this, Change Management, a strategic managerial approach helping people in an organization to transition changes, became increasingly used. In 2003, Change Management was used in only $34 \%$ organizations, but ten years later, in 2013 , it was used by $79 \%$ organizations worldwide [19]. In a large survey, managers showed that companies with excellent Change Management programs were six times more likely to meet or exceed their objectives [19].

Romanian T\&C enterprises are operating in a tumultuous global environment, with frequent changes in value chains, and having to bear a mostly unfavourable national economic conjuncture. These, next to the fact that Romania is the second T\&C employer in Europe, are only few of the reasons why organizations should adopt Change Management and managers should be trained to help their employees implement changes initiatives efficiently. Only in this way organizations will ensure their long term survival, based on value added, investments in research, new technologies and upgraded management practices.

Change management is a strategically planned process, where organizations are committed to cross from one state to another desired one, in order to be efficient within their turbulent environment, while handling personnel's resistance and preparing the organization for implementing and sustaining change [20-25].

Since 1911, when Taylor described the necessity of people accepting organizational change, numerous scholars and enterprises developed a series of models to help organizations implementing change management [27]. But change happens differently in each enterprise, depending on its culture, resources, managerial capabilities, structure, organizational life cycle etc. This is why, organizational change methodologies should be general enough to permit adoption in all organizations, but operational enough to permit directing the change in a practical way.

After analyzing Change Management literature review (over 60 books, 100 articles and 40 websites), 34 Change Management models(Lewin, Hersey \& Blanchard, Lippitt, Watson \& Westley, Hard Systems Model of Change, Bullock \& Batten, Prosci, PMI, Anderson, Kotter etc.) [19-27 etc.], and after evaluating T\&C distinctiveness [1-17], we developed a simple and straightforward model for implementing Change Management, applicable also in textile SMEs - TexChange (figure 1).

TexChange is a sequential model, easy to implement in small and medium textile and apparel companies, including five steps:

1. Diagnosis of current situation - analyze global and national T\&C business environment to find change ideas, in order to ensure company growth (new 


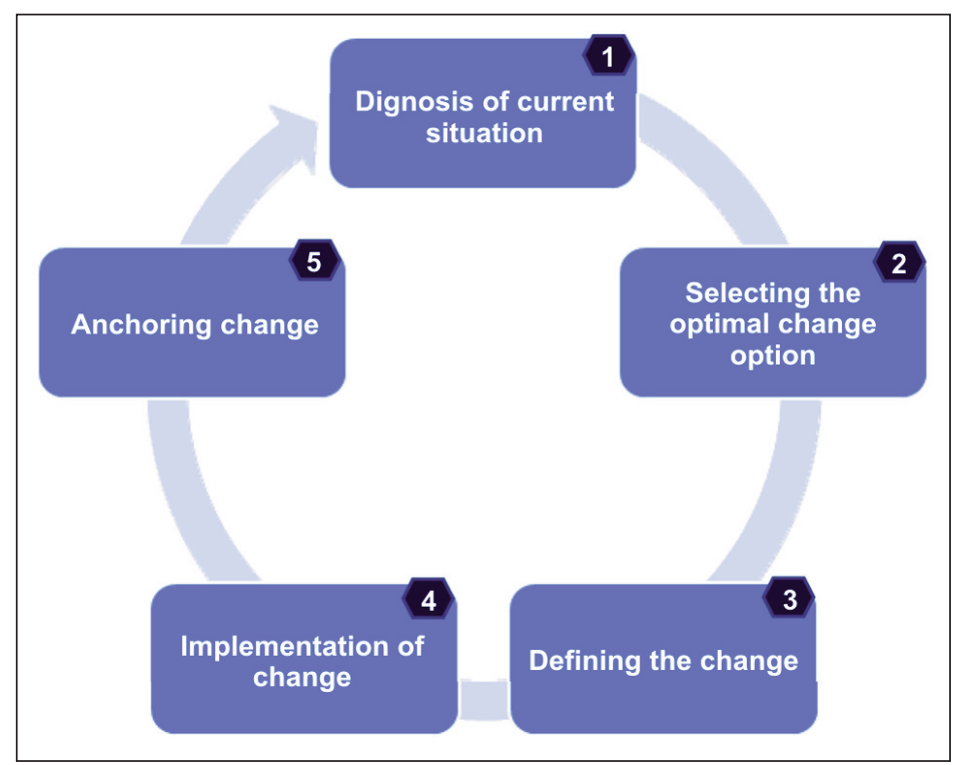

Fig. 1. TexChange - a Change Management Model for SMEs in T\&C industry

Desired investments in new technologies are hard to get financed by reluctant and risk averse banks, demanding strong balance sheets and steady profits, alongside with limited dependence on big fashion retailers that can quickly change their suppliers.

3. Defining the change - involves establishing change's vision, purpose and objectives, elaborating an operational plan to state each action and resource needed to realize the objectives, and especially planning a strategy to manage employees' resistance to change.

Planning a Change Management Project can be challenging for small or medium enterprises, especially because of the reduced managerial experience in global TC market and change management. This is why T\&C SMEs need Change Management knowledge (training, consulting, global TC market analysis), even more than larger companies, in order to ensure the success of the new

and available technologies, new strategies or products from competitors, new suppliers/clients/contractors, even outside the national borders etc.).

Fashion industry is changing so often, T\&C technologies develop so fast, market is so competitive, employees are so resistant to scary or risky changes, while shareholders push for change in order to prosper - these are some of the reasons to use Change Management and start with a diagnosis. Also, since value chains are so fluid and geographically segmented, the environment analysis must cross the national borders, in order to achieve the best value chain x-raying. There are numerous methods of diagnosis, the most famous and simplest to use in T\&C being SWOT Analysis.

2. Selecting the optimal change option - use a rational decision making process to evaluate and to rank options, considering the possible benefits, obstacles and strategies to overcome them, feasibility in achieving the objectives, etc.

Most small firms are failing because they choose to do too many changes in the same time and lack the resources to implement and finish them. Additionally, decision makers are not very proficient with online informational tools and channels, social media and online marketing strategies; simply they are not aware of the fastest ways available for spotting shifts in consumer preferences and market trends.

Although SMEs are interested in changing, they often fail to finalize the process because of the restricted funding and market data knowledge, and also for limited change process standardization and formalization. The last two favor the openness to change and for taking risks, but also creates problems regarding change implementation and consolidation on long term. Therefore, selecting the most important change for the organization and continuing with it in a standardized way focus organizational efforts and investment in the most appropriate project. strategy implementation and the continuity of change. TC companies are particularly exposed in this phase due to limited experience of their owners (in many situations acting also as general managers), this kind of exceptional analysis and decisional phase having long term implications. Also, funds unavailability for hiring external consulting support or even lack of acceptance of the need for specialized help create additional barriers. Good employees with adequate skills are hard to find, being attracted by higher salaries and jobs in multinational or big TC companies.

4. Implementation of change - is initiated, communicated, coordinated, evaluated (feedback instruments and key performance indicators) and adapted accordingly, by the General Manager or another delegated Agent of Change.

The close relationships between employees and managers in T\&C SMEs determine a better communication regarding the vision of change compared to larger organizations. This is a favourable factor for change implementation, but decreases managers' authority to reinforce it. Implementation must follow the planning from the previous point.

5. Anchoring change - into organizational culture and practice; can be realized through evaluating and communicating the intermediary results, celebrating success and rewarding contributions, adapting the operational plan to received feedback.

The low level of standardization and formalization in SMEs create problems regarding consolidating change on long term, people having the tendency to return to the old way of doing things when they are not compelled by a formalized process or incentivized adequately. Low wages might be one of the most important competitive advantage of Romanian T\&C industry, but it is also a cause of dissatisfaction for personnel and lack of involvement in discretionary activities, as those involved in changes initiatives. 
When monetary rewards are limited, anchoring change process needs more creative incentives.

Padilha and Gomes [2] analysed the factors that encourage development of innovation culture in textile industry, which proved to be very similar with change management factors: company strategy (mission and vision, focus on client, management processes, leadership and support mechanisms, guiding behaviour and actions), structure (fostering innovation, hindering change resistance), support mechanisms (rewards and recognition, information and creativity, time flexibility, therefore a favourable organisational culture), behaviours that stimulate innovation (multidisciplinary teams, failure causes identification, fault tolerance, rewarding success, recognizing contributions) and communication (clarity, communication routines). Their research showed that "the dimensions of Innovation Culture that had a greater impact on Performance in Innovation of Textile Products were Structure and Behaviours which foster innovation. Thus, it is noticed a strong influence of the decision-making process formalization, flexibility of working structure, work in teams, appreciation of ideas and update knowledge on performance in product innovation" [2]. Change management nurtures all these.

Main factors determining the success of a Change Management Project [19, 27] are: (1) actively promoting and supporting the change initiative - realized by an Agent of Change, which in SMEs often is the General Manager, sometimes, helped by a consultant in Change Management; (2) communicating clearly about the change initiative - messages have to be adapted to the public, have to reflect the solutions for possible problems, determining the reduction of change resistance; (3) integrating Project Management with Change Management raises the chances to have a successful project, meaning to achieve organizational objectives in projected time and budget; (4) approaching Change Management in a formal and structured manner in order to maximize its results; (5) understanding the role of time in Change Management - measures must consider both short term and long term adoption of change, as well as short term and long term results of change; (6) building an organizational culture open to change.

\section{CONCLUSIONS}

Textile and Clothing is an industry currently facing tremendous challenges and disruptive changes, triggered by new and capital intensive technologies, relocation arbitrage on labor costs, regional formal and informal protectionism, volatile consumer preferences and, most important, a real need for updated managerial skills. Trends as globalization, search for lowest costs, increasing competition, reshoring the production, technologizing products, technologizing production and commercialization processes etc. determine changes in every enterprise - small, medium or large. Small and medium enterprisesare encountering higher levels of turbulence in their environment, due to their scarcity of resources and challenging relationships with their stakeholders. Their need to adapt to continuously changing environment and strategically influence their success can be fulfilled using TexChange, a Change Management model for T\&C.

In spite of some positive indicators (Index of turnover, employees and companies number, etc.), analysis of Romanian T\&C industry showed a lower turnover per employee than in other countries. This situation is probably determined by multiple factors, such as reduced level of investments in new technologies, limited funding, highly competitive market etc., and suggests that strategic change is highly needed.

Operational superiority has to be complemented by strategic and change management excellence. In a highly fragmented market, dominated by big multinational brands, survival and success of the rest of SMEs active in this industry will rely on flexibility and capacity to adapt to the new rules of the game, access to information in real time and competent change management skills. Current paper offers a structured and straightforward strategic approach for Romanian and foreign T\&C SMEs, in order to improve their turnover and profitability: objective (self)assessment, selection of optimal change alternative, change definition, planning and implementation, finalizing with a stable and reinforced change anchoring.

\section{BIBLIOGRAPHY}

[1] Euratex (The European Apparel and Textile Confederation), Key Figures 2016 - The EU-28 Textile and Clothing Industry in the year 2016, 2016 http://euratex.eu/fileadmin/user_upload/images/key_data/Euratex_Keyfigures_2016-HR.pdf

[2] Padilha, C.K., Gomes, G. Innovation culture and performance in innovation of products and processes: a study in companies of textile industry, In: RAI Revista de Administracao e Inovacao, 2016, no. 13, pp. 285-294.

[3] Lu, S., Mok, P. Y., Jin, X. A new design concept: 3D to 2D textile pattern design for garments, In: Computer-Aided Design, 2017, no. 89, pp. 35-49.

[4] McKinsey \& Company, The state of Fashion, 2017, https://www.businessoffashion.com/site/uploads/2016/11/ The_State_of_Fashion_2017.pdf 
[5] EURACTIV, European Textiles and Fashion: Facts \& Figures, https://www.euractiv.com/section/innovation-industry/ infographic/european-textiles-and-fashion-facts-figures/

[6] McAdam, R., McClelland, J. Sources of new product ideas and creativity practices in the UK textile industry, In: Technovation, 2002, no. 22, pp. 113-121ß.

[7] Technavio report, Global Smart Textiles Market 2016-2020, https://www.technavio.com/report/global-textile-fiberand-composites-global-smart-textiles-market-2016-2020

[8] Becker, S., Hornung, E, Woessmann, L. Education and Catch-Up in the Industrial Revolution, In: American Economic Journal:Macroeconomics, 2011, vol. 3, no. 3, pp. 92-126 2011:97

[9] Kiziloglu, M., Serinkan, C. Perception of Strategical Management in Textile Sector, In: Procedia - Social and Behavioral Sciences, 2015, no. 207, pp. 306-314.

[10] Serbanel, C. I. Romanian Textile Industry and its competitive advantage, In: SEA - Practical Application of Science, 2014, vol. II, Issue 2(4), pp. 395-404.

[11] Fibre2Fashion Pvt. Ltd, Fibre statistics, 2016, http://www.fibre2fashion.com/market-intelligence/industryinsight/industry/

[12] European Commission, Trade report comparison per year (Yearly totals), In: ATRIUM Data Warehouse, ITI Domain TEXTILE, 2017.

[13] National Institute of Statistics, Romanian Statistical Yearbook 2016.

[14] Ohno, T., The Toyota productive system: Beyond large scale production, Productivity Press, Portland, OR., 1988.

[15] lacocca Institute, 21st Century Manufacturing Enterprise Strategy. An Industry-Led View, In: vol. 1/2, Bethlehem, PA., 1991.

[16] Bruce, M. Daly, L., Towers, N. Lean or agile. A solution for supply chain management in the textiles and clothing industry? In: International Journal of Operations \& Production Management, 2004, vol. 24, no. 2, pp. 151-170.

[17] EUROSTAT, 2017, http://ec.europa.eu/eurostat/data/database

[18] Pulak, M., Divesh, M.,Divesh, P. Market concentration in Indian Manufacturing Sectors: Measurement issues, In: Economic and Political Weekly, 2011, vol. 46, no. 49, pp. 76-80.

[19] Prosci, Best Practices in Change Management, 2014, http://offers.prosci.com/research/Prosci-2014-BestPractices-Executive-Overview.pdf

[20] Singh, K., Saeed, M., Bertsch, A. Key factors influencing employee responses towards change: a test in the telecom industry in India, In: Journal of Management Policy and Practice,2012, vol. 13, no. 3, pp. 66-81.

[21] Taher, N. A. B., Krotov, V., Silva, L. A framework for leading change in the UAE public sector, In: International Journal of Organizational Analysis, 2015, vol. 23, no. 3, pp. 348-363.

[22] Holbeche, L., Leading edge, In: Development and Learning in Organizations, 2011, vol. 25, no. 5, pp. $39-42$.

[23] Sirkin, H. L., Keenan, P., Jackson, A. The hard side of change management, In: Harvard Business Review, 2005, vol. 83, no. 10, pp. 109-118.

[24] Kotter, J. P., Schlesinger, L. A, Choosing strategies for change, In: Harvard Business Review, July-August 2008, https://globalleadershipfoundation.com/assets/files/2013/04/Choosing-strategies-for-change-KOTTER.pdf

[25] Project Management Institute (PMI), Managing change in organizations: A practice guide, 2013, http://www.pmi.org/ /media/Files/Home/ManagingChangelnOrganizations_A_Practice_Guide.ashx

[26] Taylor, F.W. The principles of scientific management, NY, USA and London, UK: Harper \& Brothers, 1911

[27] Project Management Institute (PMI) (2014), PMI's pulse of the profession in-depth report: Enabling organizational change through strategic initiatives, http://www.pmi.org/ /media/PDF/Publications/Enabling-Change-ThroughStrategic-Initiatives.ashx

\section{Authors:}

LIVIU TUDOR

Bucharest Business University, Faculty of Management

Bucharest, Romania

e-mail: It@idgrup.ro

Corresponding author:

LIVIU TUDOR

e-mail: It@idgrup.ro 


\section{The gamma radiation shielding effectiveness of textured steel yarn based fabrics}

\section{REZUMAT - ABSTRACT}

\section{Eficiența ecranării radiațiilor gamma a țesăturilor cu conținut de fire din oțel texturat}

Vestele de protecție pe bază de plumb care au eficiență împotriva radiațiilor electromagnetice sunt utilizate, în general, pentru protecția personală a medicilor și a pacienților împotriva radiațiilor X (gamma) în timpul operațiilor din domeniul medical; cu toate acestea, plumbul are dezavantaje ecologice, având toxicitate ridicată. Scopul acestui studiu a fost de a realiza un material de protecție împotriva radiațiilor pe bază de materiale textile ecologice și flexibile. În această lucrare au fost utilizate tesături 2/2 diagonal, 3/1 diagonal, Herringbone, Whipcord, care sunt derivate din legătura diagonal, țesături Barathea și Crêpe, derivate din legătura satin, țesături cu fire de oțel texturate, care au tușeu moale și sunt flexibile, pentru care s-a investigat eficiența ecranării radiațiilor gamma, care nu a fost studiată în referințe.

Efectele caracteristicilor structurale ale țesăturilor, cum ar fi tipul de legătură, densitatea firului de bătătură, grosimea țesăturii și porozitatea, au fost analizate grafic și statistic. Se observă că, având cele mai mari grosimi și cele mai scăzute porozități, țesăturile Barathea și Crêpe au avut performanțe mai bune de ecranare a radiațiilor gamma decât celelalte tipuri de țesături. Probele F1 și E1, țesute cu legături Barathea și Crêpe, au cea mai mare eficacitate de ecranare a radiației gamma, datorită celei mai mari de grosimi a țesăturii și a celei mai scăzute porozități. În plus, creșterea densității firelor de oțel texturat a îmbunătățit eficacitatea ecranării radiației gamma a țesăturilor.

Cuvinte-cheie: legătură diagonal, legătură derivată, țesături, radiație gamma, eficiența ecranării radiațiilor gamma, fir de oțel texturat

\section{The gamma radiation shielding effectiveness of textured steel yarn based fabrics}

Lead aprons that are lead-shielding products are generally used for personal protection of physicians and patients from $X$-ray (gamma) radiation during medical operations; lead has environmental disadvantages, with high toxicity, though. Therefore, the aim of this research was to produce an environmentally friendly and flexible textile-based radiation shielding material. In this work, 2/2 twill, 3/1 twill, Herringbone, Whipcord, which are twill derivatives, Barathea and Crêpe woven fabrics, which are sateen derivatives, woven with textured steel yarns, which have soft feeling and flexibility, and gamma radiation shielding effectiveness of these fabrics were investigated and were not studied in the references.

The effects of fabric structural characteristics such as weave, conductive weft yarn density, fabric thickness and porosity on these properties were analysed graphically and statistically. It is observed that with the biggest thicknesses and lowest porosities, Barathea and Crêpe woven fabrics performed better gamma radiation shielding performance than other woven fabrics. The samples F1 and E1, woven with Barathea and Crêpe weave, have the highest gamma radiation shielding effectiveness, thanks to the highest fabric thicknesses and lowest porosities. In addition, the increases of textured steel yarn density improved the gamma radiation shielding effectiveness of woven fabrics.

Keywords: twill weave, derivative weave, woven fabrics, gamma radiation, gamma radiation shielding effectiveness, textured steel yarn

\section{INTRODUCTION}

Apart from three basic weaves namely plain, twill and sateen weaves, there are derivative of these weaves. The idea behind developing these weaves is to obtain physical and aesthetic characteristics in the fabric somewhat different than those obtained with the basic weaves. In derivative weaves properties intermediary between these main groups are obtained. This is achieved by rearranging the basic weave structures by the application of certain methods to give the desired result [1].

As a generalized notion, the radiation is propagation of electromagnetic or particle energy which are two portions of radiation concept. However, the radiation is the general name of different characteristic energies. Radiations kinds realize the radiation spectrum.
Many of radiation kinds are known by the people such as visible light, heat, radio waves, ultra violet waves (UV) and micro waves but not know they are radiation. All radiation types of electromagnetic energy are made by the same thing which is just electric and magnetic field coupling but different frequencies. Visible region is the frontier in the large electromagnetic radiation spectrum. As energy value, under the light all kinds of radiations cannot damage the matter although make a specific interaction. After light energy (figure 1) the radiation has a name: ionizing radiation and nuclear radiation. UV region starts to damage the matter by separating the electrons.

While the frequency increases the energy of the radiation decreases. Visible region has several $\mathrm{eV}$ (electronvolt, $1 \mathrm{eV}=1.6 \times \mathrm{E}^{-19}$ Joule) unit energy but 
UV region has several keV (kilo eV). $13.6 \mathrm{eV}$ energy is needed to separate an electron from hydrogen atom but visible and other regions under UV have not enough such energy. $X$ ray regions have energies several ten keV to several MeV. Secondly, after the electromagnetic radiation, there is particle radiation that has completely effect of ionizing. These particles come from atomic nuclei of radioactive materials, outer space and scientific facilities. Alpha, beta and neutrons are commonly used and known in many of particle type. Particle radiation can be easily shielded and there cannot be faced

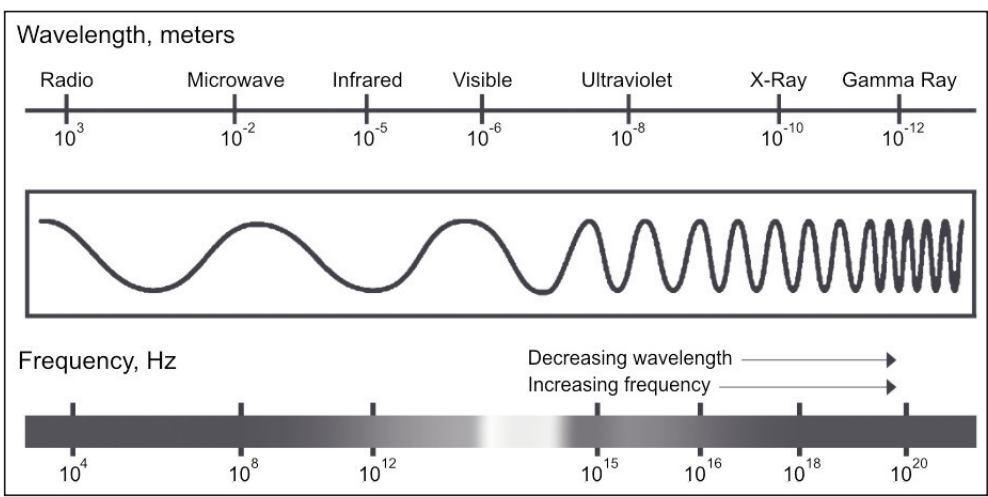
in people life. On the other hand, electromagneticionizing radiation cannot be easily stopped. So it is important to care ionizing radiation for alive organism because ionizing radiation definitely damages the DNA. The DNA damages are commonly repaired by the organism but always there are permanent DNA damage risks. Sometime the risk turns into reality of cancer or genetically mutation. In practical life, we live in lonizing Radiation Sea additionally other nonionizing radiations. Natural earth materials and the sun are main radiation source for us. Also, humans can face the ionizing radiation artificially by medical applications which include diagnostic and therapy treatments.

Humans try to avoid all the radiation types as degree of their information about radiation concept. Although protection of particle radiation does not need remarkable effort, electromagnetic radiation, also particularly the ionizing region of the electromagnetic spectrum has wide research and job area in radiation protection. Especially, medical physics area almost consists of ionizing or nuclear radiation applications. The people that are except radiation workers are named the public in ionizing radiation application. Radiation workers have more widen tolerance protocols than public because of their controlled conditions. However, the conditions are not controlled in radiation protection in the practical life of the public. Commercially, there are many products which put forwarding a protection for radiation shielding. Many of them are useless and out of scientific realities. Despite these, it is needed to protect the people from ionizing radiation. Annual radiation dose that comes from cosmic and terrestrial radiation is $2.4 \mathrm{mSv}$ meanly [3-5] and this value is higher than a single lung Rontgen exposure [6]. Also, radiation workers need continuous protection shielding instead of heavy lead during daily medical jobs out of specific radiation treatments.

User friendly and light wearing fabrics or materials have been always important the subject of radiation protection in scale from high school's projects to specialized scientific researches. Therefore researchers applied chemical treatments to enhance the gamma radiation shielding effectiveness of fabrics:

Fig. 1. Electromagnetic radiation spectrum [2]

Maghrabi et al. coated $100 \%$ polyester and nylon plain woven fabrics with bismuth oxide [7]. They found that coated polyester fabrics with over $50 \%$ $\mathrm{Bi}_{2} \mathrm{O}_{3}$ showed enhanced shielding ability for transmitted X-rays. Aral, Nergis and Candan coated the cotton fabrics with silicone rubber that contains tungsten, bismuth or barium sulphate powders in equal weight fractions [8]. The results showed that, at $60 \%$ weight ratio, $1.55 \mathrm{~mm}$ bismuth embedded coating could attenuate $90 \%$ of X-ray photons at the $100 \mathrm{kV}$ level, while the required thickness of a tungsten embedded coating was $1.73 \mathrm{~mm}$ for the same protection level. Qu et al. fabricated a series of X-ray radiation-resistant fibres via a primarily industrialized wet-spinning trail, and knitted the resultant fibres into fabrics by knitting loom [9]. The X-ray attenuation ratio of the sample tended to increase with increasing barium sulphate content and finally reached a dose of a $0.1 \mathrm{~mm}$ thick lead equivalent.

Electromagnetic-ionizing radiation is absorbed in different percentages by different element media. While atomic number of element increases, absorption fraction increases so the lead has the heaviest number in periodic table as friendly usage. Material technology or composition cannot affect the absorption amount, just atomic number or effective atomic number (effective atomic number is defined for mixtures or compounds similar element numbers in nuclear science) of material elements. In consideration of fabric production techniques, technologies and science, radiation-mass interactions are not relevant with them. Mechanism of radiation interactions is directly dependent on mass atomic properties and initial radiation energy. So the shielding made by lead is popular and indispensable still despite improved technology of humankind because the lead atoms have heavy and wide nuclei independently from macro features of materials. This cannot be ignored to develop radiation shielding materials. The way is inserting material with heavy atom into the expected fabric for significant radioprotection.

The studies in literature focused on chemical treatment of plain woven fabrics. However gamma radiation shielding effectiveness of fabrics woven with textured steel yarns has not been investigated. If a fabric is required to be radiation-shielded, firstly it should 
include bigger atomic number material in its pattern. Common fabrics were manufactured with organic or synthetic materials which do not contain bigger atom than themselves. Metals are most suitable matters for radiation protection so in this study stainless steel contributed fabric was investigated. Steel is consisting of mostly iron and rarely carbon. Carbon fraction determines the type of the steel. Iron has 26 atomic number. This is almost bigger than common fabric material atoms. There are bigger atoms than steel but industrial treatments have limitation for all elements. Steel is user-friendly to put it into a fabric, economic and non-toxic for an organism. The aim of this study was to investigate the effects of fabric structural parameters, which are weave, conductive weft yarn density, fabric thickness and porosity on gamma radiation shielding effectiveness of the $2 / 2$ twill, $3 / 1$ twill and certain derivative woven fabrics. In this regard, an experimental study has been carried out and then, the effects of the parameters have been detected firstly by graphics formed by obtained data and secondly by analysis of variance.

\section{MATERIAL AND METHODS}

\section{Material}

In this research 24 types of woven fabric samples $(42 \times 42 \mathrm{~cm})$ were produced in Weaving Workshop of in-house by $\mathrm{CCl}$ automatic sample rapier loom (Evergreen 8900, Taiwan). 100\% polyester yarns and textured stainless steel yarns, which have soft feeling and flexibility, required properties for fabrics, were used. The optical image of the textured steel yarn was taken by using Olympus BX 43 Microscopy as shown in figure 2 . The specifications of yarns are given in table 1 . Weave patterns are shown in figure 3 . While the conductive steel yarns were inserted in certain intervals to obtain different open grid structures of conductive yarn within the fabrics, which resulted in different conductive weft yarn densities, the conductive and the polyester yarns were used in 1 to 4 orders as warp yarns. The characteristics of the conductive fabrics are shown in table 2 . The open grid structures of the conductive yarns are represented with grey squares and letter of $T$, whereas the polyester yarns are represented with white squares and letter of Pin figure 4. Both white and grey squares also represent intersection points between warp and weft yarns. Warp and weft settings of 24 kinds of woven fabric samples on the loom were $20 \mathrm{~cm}^{-1}$, which was calculated for the loom state. And also reference samples were woven for all kinds of weaves with only $100 \%$ polyester warp and wefts.

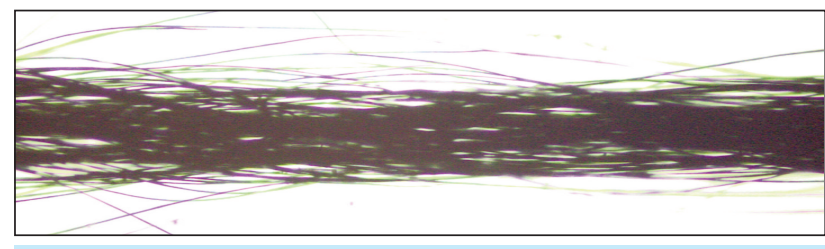

Fig. 2. Optical image of textured steel yarn

Table 1

\begin{tabular}{|l|c|c|c|}
\hline \multicolumn{1}{|c|}{ Material } & $\begin{array}{c}\text { Yarn } \\
\text { count } \\
\text { (dtex) }\end{array}$ & $\begin{array}{c}\text { Diameter } \\
\text { of wire } \\
(\mathbf{m m})\end{array}$ & $\begin{array}{c}\text { Conductor } \\
\text { resistance } \\
\left(\mathbf{\Omega} \mathbf{m m}^{2} / \mathbf{m}\right)\end{array}$ \\
\hline Polyester yarn & 600 & 0.02 & - \\
\hline Textured steel yarn & 695 & 0.037 & 0.013 \\
\hline
\end{tabular}

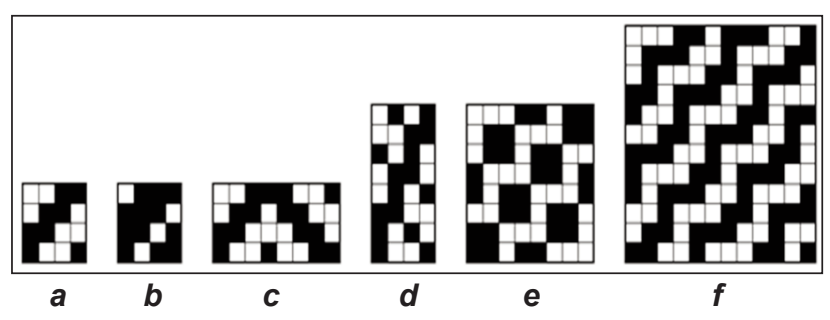

Fig. 3. Weave patterns used in experimental: $a-2 / 2$ Twill, $b-3 / 1$ Twill, $c-$ Herringbone, $d$ - Whipcord, e - Barathea, $f$ - Crêpe

Table 2

\begin{tabular}{|c|c|c|c|c|c|}
\hline $\begin{array}{l}\text { Fabric } \\
\text { code }\end{array}$ & $\begin{array}{l}\text { Weave } \\
\text { pattern }\end{array}$ & $\begin{array}{l}\text { Warp } \\
\text { density on } \\
\text { the reed } \\
\left(\mathrm{cm}^{-1}\right)\end{array}$ & \begin{tabular}{|c|} 
Weft \\
density on \\
the loom \\
$\left(\mathrm{cm}^{-1}\right)$
\end{tabular} & $\begin{array}{l}\text { Yarn } \\
\text { type* }\end{array}$ & $\begin{array}{c}\text { Fabric } \\
\text { composition } \\
\text { (warp } \times \text { weft) }\end{array}$ \\
\hline A1 & \multirow{4}{*}{ 2/2 Twill } & \multirow{4}{*}{20} & \multirow{4}{*}{20} & TP 1:1 & $1 \mathrm{~T} 4 \mathrm{P} \times 1 \mathrm{~T} 1 \mathrm{P}$ \\
\hline $\mathrm{A} 2$ & & & & TP 1:2 & $1 \mathrm{~T} 4 \mathrm{P} \times 1 \mathrm{~T} 2 \mathrm{P}$ \\
\hline A3 & & & & TP 1:4 & $1 \mathrm{~T} 4 \mathrm{P} \times 1 \mathrm{~T} 4 \mathrm{P}$ \\
\hline A4 & & & & TP 1:8 & $1 \mathrm{~T} 4 \mathrm{P} \times 1 \mathrm{~T} 8 \mathrm{P}$ \\
\hline B1 & \multirow{4}{*}{ 3/1 Twill } & \multirow{4}{*}{20} & \multirow{4}{*}{20} & TP 1:1 & $1 \mathrm{~T} 4 \mathrm{P} \times 1 \mathrm{~T} 1 \mathrm{P}$ \\
\hline B2 & & & & TP 1:2 & $1 \mathrm{~T} 4 \mathrm{P} \times 1 \mathrm{~T} 2 \mathrm{P}$ \\
\hline B3 & & & & TP 1:4 & $1 \mathrm{~T} 4 \mathrm{P} \times 1 \mathrm{~T} 4 \mathrm{P}$ \\
\hline B4 & & & & TP 1:8 & $1 \mathrm{~T} 4 \mathrm{P} \times 1 \mathrm{~T} 8 \mathrm{P}$ \\
\hline C1 & \multirow{4}{*}{ Herringbone } & \multirow{4}{*}{20} & \multirow{4}{*}{20} & TP 1:1 & $1 \mathrm{~T} 4 \mathrm{P} \times 1 \mathrm{~T} 1 \mathrm{P}$ \\
\hline $\mathrm{C} 2$ & & & & TP 1:2 & $1 \mathrm{~T} 4 \mathrm{P} \times 1 \mathrm{~T} 2 \mathrm{P}$ \\
\hline C3 & & & & TP 1:4 & $1 \mathrm{~T} 4 \mathrm{P} \times 1 \mathrm{~T} 4 \mathrm{P}$ \\
\hline C4 & & & & TP 1:8 & $1 \mathrm{~T} 4 \mathrm{P} \times 1 \mathrm{~T} 8 \mathrm{P}$ \\
\hline D1 & \multirow{4}{*}{ Whipcord } & \multirow{4}{*}{20} & \multirow{4}{*}{20} & TP 1:1 & $1 \mathrm{~T} 4 \mathrm{P} \times 1 \mathrm{~T} 1 \mathrm{P}$ \\
\hline D2 & & & & TP 1:2 & $1 \mathrm{~T} 4 \mathrm{P} \times 1 \mathrm{~T} 2 \mathrm{P}$ \\
\hline D3 & & & & TP 1:4 & $1 \mathrm{~T} 4 \mathrm{P} \times 1 \mathrm{TT} 4 \mathrm{P}$ \\
\hline D4 & & & & TP 1:8 & $1 \mathrm{~T} 4 \mathrm{P} \times 1 \mathrm{~T} 8 \mathrm{P}$ \\
\hline E1 & \multirow{4}{*}{ Barathea } & \multirow{4}{*}{20} & \multirow{4}{*}{20} & TP 1:1 & $1 \mathrm{~T} 4 \mathrm{P} \times 1 \mathrm{~T} 1 \mathrm{P}$ \\
\hline E2 & & & & TP 1:2 & $1 \mathrm{~T} 4 \mathrm{P} \times 1 \mathrm{~T} 2 \mathrm{P}$ \\
\hline E3 & & & & TP 1:4 & $1 \mathrm{~T} 4 \mathrm{P} \times 1 \mathrm{TT} 4 \mathrm{P}$ \\
\hline E4 & & & & TP 1:8 & $1 \mathrm{~T} 4 \mathrm{P} \times 1 \mathrm{~T} 8 \mathrm{P}$ \\
\hline F1 & \multirow{4}{*}{ Crêpe } & \multirow{4}{*}{20} & \multirow{4}{*}{20} & TP 1:1 & $1 \mathrm{~T} 4 \mathrm{P} \times 1 \mathrm{~T} 1 \mathrm{P}$ \\
\hline F2 & & & & TP 1:2 & $1 \mathrm{~T} 4 \mathrm{P} \times 1 \mathrm{~T} 2 \mathrm{P}$ \\
\hline F3 & & & & TP 1:4 & $1 \mathrm{~T} 4 \mathrm{P} \times 1 \mathrm{~T} 4 \mathrm{P}$ \\
\hline F4 & & & & TP 1:8 & $1 \mathrm{~T} 4 \mathrm{P} \times 1 \mathrm{~T} 8 \mathrm{P}$ \\
\hline
\end{tabular}

* $\mathrm{T}$ represents textured steel yarn, $\mathrm{P}$ represents polyester yarn 


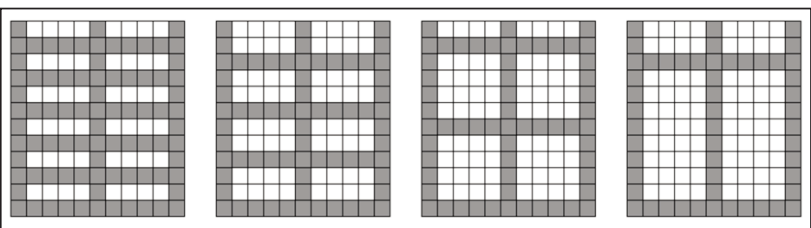

Fig. 4. Schematic diagram of open-grid structures formed in the woven fabrics (grey squares: conductive steel yarns; white squares: polyester yarns)

Fabric samples have been coded according to their weave pattern, warp and weft densities as in table 2 . The letter and number in each fabric code represent weave patterns and weft yarn arrangement respectively.

\section{Method}

The thickness of fabrics was measured with Digital Thickness Gauge Meter. Five numbers of the samples were measured.

The porosities of fabrics were calculated by [10]

$$
\varepsilon=1-\frac{\rho_{a}}{\rho_{b}}
$$

where $\rho_{a}$ is the fabric density $\left(\mathrm{g} / \mathrm{cm}^{3}\right), \rho_{b}$ is the fibre density $\left(\mathrm{g} / \mathrm{cm}^{3}\right)$ and $\varepsilon$ is the porosity. Fabric density is calculated by dividing the fabric weight per unit area, by fabric thickness.

Radiation absorption measurements of prepared samples of fabric types were performed using Geiger Muller (GM) gas filled radiation detector in the geometry as shown with figure 5. Preferring cause of GM detector is detection efficiency for total gamma radiation energy instead of spectroscopic Scintillators of semi-conductor crystals. Also dose studies are commonly based on gas filled detectors (such as ionization chambers) for all type of radiation particles in dosimetry science.

Firstly, a background (absence of non-natural radiation source) radiation was counted to correct the main counting. In step one, americium (Am-241) gamma radiation was counted several times to get mean radiation rate in determined time in geometry of figure 3 while there is no fabric sample between detector and the source. This mean value represents "I0" initial intensity of radiation beams that reach to GM detector. In step two, radiation detection-counting was done while each sample is between source and GM detector. This value represents "I" transferred part of gamma radiation by the samples. Transfer and abruption rates of the samples were calculated by fractions of $1 / / 0$. Each sample was measured five times.

Am-241 radionuclide was used as radiation source (point source geometry). Single source energy was used instead of variable energies because to use different energies the $\mathrm{x}$-ray tube is needed and properly

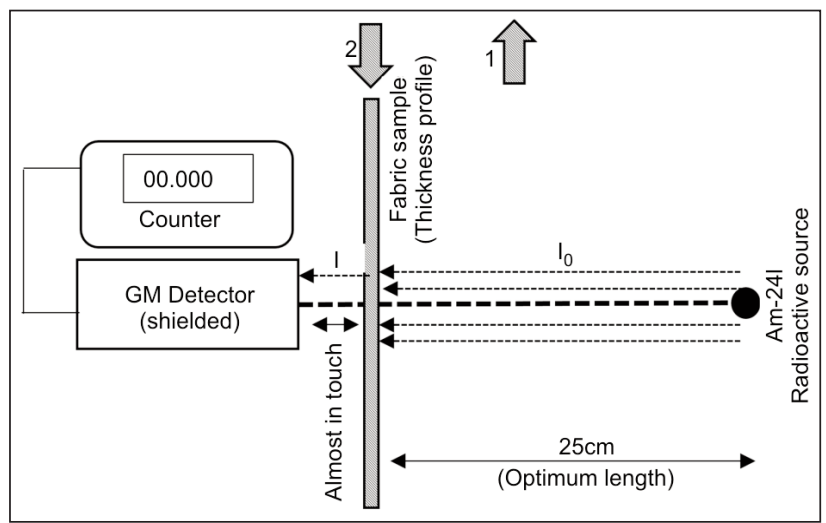

Fig. 5. Illustration of radiation (nuclear) absorption experiment. $1-I_{0}$ initial intensity was counted without a fabric sample in air media. 2 - I intensity was counted while the sample is between detector and source

radioprotection shielding during experiment. Despite this situation Am-241 has gamma energy (figure 6) in scale of $\mathrm{x}$-ray region and this region is comparable medical radiation energies.

While transferred part, $T$, was calculated from equation (2), absorbed part, $A$, was calculated from equation (3);

$$
T=\frac{I}{I_{0}} \times 100
$$

where $I_{0}$ is initial intensity, namely gamma counting without absorber, I - transferred intensity, namely gamma counting with absorber.

$$
A=100-T
$$

In this method it is not needed to calculate real intensity 10 because $\mathrm{I} / \mathrm{IO}$ rate does not change by calculating real (raw) counting rate in unit count/time.

Radiation absorption measurements were evaluated statistically by ANOVA according the General Linear Model with SPSS 15.0 software package. In order to analyze the effect of weave and conductive weft

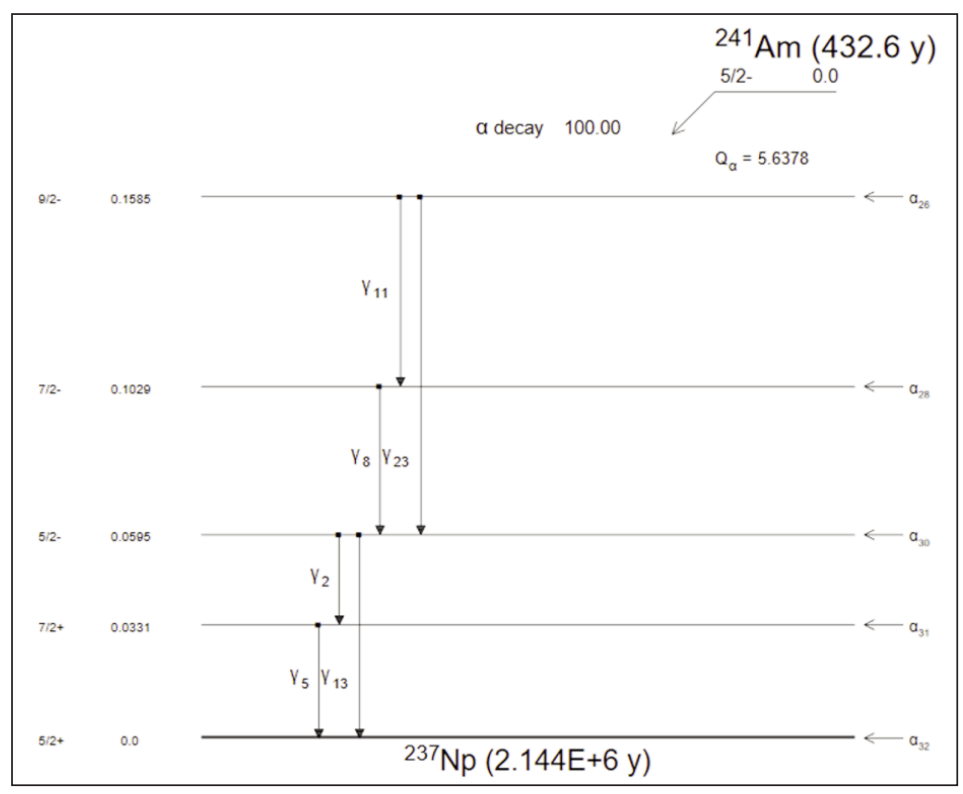

Fig. 6. Decay Scheme of Am-241 [9] 
density, multivariate analysis was made. Significance degrees $(p)$, which were obtained from ANOVA, were compared with significance level $(\alpha)$ of 0.05 . The effect, whose significance degree was lower than 0.05 , was interpreted as statistically important.

\section{RESULTS AND DISCUSSIONS}

The averages of thickness, porosities and gamma radiation measurements are given in table 3 . Initial intensity was counted as $479 \mathrm{cpm}$ (count per minute). It is seen from table 3 that if the fabric thickness increased and the porosity decreased the transferred intensity decreased.

Table 3

\begin{tabular}{|c|c|c|c|c|}
\hline $\begin{array}{c}\text { Fabric } \\
\text { code }\end{array}$ & $\begin{array}{c}\text { Thickness } \\
\text { (mm) }\end{array}$ & Porosity & $\begin{array}{c}\text { Transferred } \\
\text { intensity } \\
\text { (cpm) }\end{array}$ & $\begin{array}{c}\text { Transferred/ } \\
\text { initial } \\
\text { Percent (\%) }\end{array}$ \\
\hline A1 & 0.66 & 0.16 & 338 & 70.56 \\
\hline A2 & 0.64 & 0.17 & 341 & 71.19 \\
\hline A3 & 0.63 & 0.19 & 345 & 72.03 \\
\hline A4 & 0.62 & 0.21 & 348 & 72.65 \\
\hline B1 & 0.69 & 0.15 & 334 & 69.73 \\
\hline B2 & 0.68 & 0.16 & 337 & 70.35 \\
\hline B3 & 0.66 & 0.18 & 341 & 71.19 \\
\hline B4 & 0.65 & 0.20 & 345 & 72.03 \\
\hline C1 & 0.72 & 0.14 & 329 & 68.68 \\
\hline C2 & 0.71 & 0.15 & 333 & 69.52 \\
\hline C3 & 0.69 & 0.17 & 337 & 70.35 \\
\hline C4 & 0.68 & 0.19 & 340 & 70.98 \\
\hline D1 & 0.76 & 0.13 & 325 & 67.85 \\
\hline D2 & 0.74 & 0.14 & 328 & 68.48 \\
\hline D3 & 0.72 & 0.16 & 332 & 69.31 \\
\hline D4 & 0.71 & 0.18 & 336 & 70.15 \\
\hline E1 & 0.79 & 0.12 & 320 & 66.81 \\
\hline E2 & 0.77 & 0.13 & 323 & 67.43 \\
\hline E3 & 0.75 & 0.15 & 327 & 68.27 \\
\hline E4 & 0.74 & 0.17 & 331 & 69.10 \\
\hline F1 & 0.82 & 0.11 & 316 & 65.97 \\
\hline F2 & 0.80 & 0.12 & 319 & 66.60 \\
\hline F3 & 0.79 & 0.14 & 322 & 67.22 \\
\hline F4 & 0.78 & 0.16 & 325 & 67.85 \\
\hline
\end{tabular}

While the samples F1-F5 and E1-E5, whose thicknesses are the biggest and porosities are the lowest, have the lowest transferred intensity, the samples A1-A5 and B1-B5, whose thicknesses are the lowest and porosities are the biggest, have the highest transferred intensity. Moreover, when the density of conductive weft yarn increased, the transferred intensity is increased as expected.

The transferred and absorbed parts of radiation for each fabric are shown in figure 7 . It is observed from figure 6 that while absorbed part of radiation increased agreement with fabric thickness, transferred

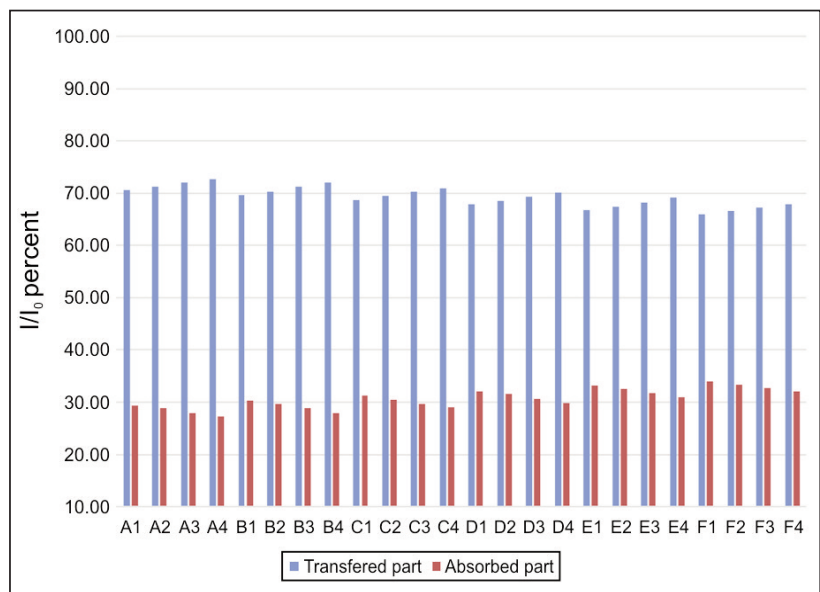

Fig. 7. The transferred and absorbed parts of radiation for fabrics

part of radiation decreased. The samples F1-F5 and E1-E5 have the lowest transferred part of radiation due to their highest fabric thicknesses, whereas; samples A1-A5 and B1-B5 have the highest transferred part of radiation due to its lowest fabric thickness. The opposite is valid for the absorbed part of radiation. When the density of textured steel yarn decreased, transferred part of radiation increased, whereas; absorbed part of radiation decreased, as expected.

The variance analysis showed that both the effects of weave and conductive weft density on gamma radiation shielding effectiveness of conductive fabrics are statistically significant, getting the $p$-values of $(0.021)$ and $(0.013)$ respectively.

\section{CONCLUSION}

The main aim of this study was to develop lead-free, fabrics for gamma radiation shielding, focusing on the attenuation properties. Therefore, experimental study was performed within the scope of this study to determine the effects of weave and fabric thickness, which are fabric structural parameters, on the gamma radiation shielding effectiveness of $2 / 2$ twill, $3 / 1$ twill and certain derivative woven fabrics.

With the highest thicknesses and lowest porosities, Barathea and Crêpe woven fabrics performed better gamma radiation shielding efficiency than other woven fabrics. Thanks to the highest fabric thicknesses and lowest porosities, the sample F1 and E1, woven with Barathea and Crêpe, show the best gamma radiation shielding effectiveness, namely absorbed part, (34.03 and $33.19 \%)$. When the conductive weft yarn density increased, gamma radiation shielding effectiveness of fabrics increased. Theoretically synthetic or organic materials are not affective on remarkable radiation absorption as it was mentioned in the introduction section but the metal components in the yarn composition of the fabric is dominant on the effective radiation shielding. Metal (steel) density in unit surface of the fabric is deterministic factor for absorption/transfer fraction. 


\section{BIBLIOGRAPHY}

[1] Başer, G. Technique and art of weaving. In: Punto Publishing, vol. 1, İzmir, 2004 (in Turkish).

[2] Hecth, E. Optics. Pearson Education, 2002.

[3] Maiin, J., Gentner, N. and Pan, Z. Sources, effects and risks of ionizing radiation. In: United Nations Scientific Committee on the Effect of Atomic Radiation (UNSCEAR), United Nations, New York, 1988.

[4] Sainis, K., Burns, P., Metter, F. and Holm, L.E. Exposure from natural sources of radiation. In: United Nations Scientific Committee on the Effect of Atomic Radiation (UNSCEAR), United Nations, New York, 1993.

[5] Yonekra, Y., Pinillos Ashton, L. and Holm, L.E. Sources, effects and risks of lonizing radiation. In: United Nations Scientific Committee on the Effect of Atomic Radiation (UNSCEAR), United Nations, New York, 2000.

[6] ICRP. 1990 Recommendations of the International Commission on Radiological Protection. In: ICRP Publication, 60 (Users' Edition), 1991.

[7] Maghrabi, H.A., Vijayan, A., Deb, P., Wang, L. Bismuth oxide-coated fabrics for X-ray shielding. In: Textile Research Journal, 2016, vol. 86, issue 6, pp. 649-658.

[8] Aral, N., Nergis, F.B., Candan, C. An alternative X-ray shielding material based on coated textiles. In: Textile Research Journal, 2015, DOI: 10.1177/0040517515590409, pp. 1-9.

[9] Qu, L., Tian, M., Zhang, X., Guo, X., Zhu, S., Han, G., Li, C. Barium sulfate/regenerated cellulose composite fiber with $X$-ray radiation resistance. In: Journal of Industrial Textiles, 2015, vol. 45, issue 3, pp. 352-367.

[10] Hseih, Y.L. Liquid transport in fabric structures. In: Textile Research Journal, 1995, vol. 65, issue 5, 299-307.

[11] Balpardo, C., Capoulat, M.E., Rodrigues, D., Arenillas, P. Standardization of Am-241by Digital Coincidence Counting, Liquid Scintillation Counting and Defined Solid Angle counting Laboratorio de Metrología de Radioisótopos. CNEA, Buenos Aires, 2009.

\section{Authors:}

\section{HAKAN ÖZDEMIR ${ }^{1}$}

BERKAY CAMGÖZ ${ }^{2}$

${ }^{1}$ Dokuz Eylül University, Faculty of Engineering, Textile Engineering Department

Tınaztepe Campus, 35397 Buca/izmir, Turkey

${ }^{2}$ Ege University, Institute of Nuclear Sciences

35100 Bornova/Izmir, Turkey

Corresponding author:

HAKAN ÖZDEMIR

e-mail: h.ozdemir@deu.edu.tr

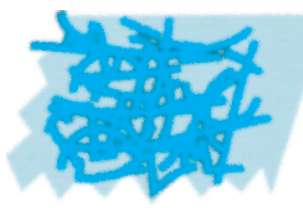




\section{$\mathrm{SIO}_{2}$ aerogels and its application in firefighter protective clothing}

\section{REZUMAT - ABSTRACT}

\section{Aerogeluri de $\mathrm{SiO}_{2}$ și aplicațiile acestora la temperatură ridicată}

Acest articol studiază utilitatea aerogelului pe bază de siliciu ca material de izolație în îmbrăcămintea de protecție utilizată la temperaturi ridicate, în special pentru pompieri. În trecut, aerogelurile au fost utilizate pentru izolarea clădirilor, în aplicații aeronautice și aerospațiale. Mai târziu, cercetătorii au determinat utilitatea aerogelilor ca substrat izolator în îmbrăcămintea de protecție. Mai multe investigații au evidențiat proprietățile de izolare ale aerogelului la temperatură ridicată. Există mai multe tipuri diferite de aerogel, dar în acest articol, accentul principal este pus pe aerogelul pe bază de siliciu datorită capacității excelente de izolare și a proprietăților ignifuge, împreună cu stabilitatea termică la temperaturi ridicate. Prin aplicarea unor tehnici adecvate de acoperire, aerogelul poate fi impregnat în substraturi nețesute, care pot fi utilizate ca bariere termice, cu rezultate în îmbunătățirea capacității de protecție a îmbrăcămintei multistratificate la temperaturi ridicate. Toate aceste caracteristici fac din aerogel un potențial candidat pentru a fi utilizat ca material izolator în îmbrăcămintea de protecție la temperaturi ridicate.

Cuvinte-cheie: aerogeluri, izolație termică, conductivitate termică, îmbrăcăminte de protecție

\section{$\mathrm{SIO}_{2}$ aerogels and its application in firefighter protective clothing}

This article focuses our attention on utility of silica based aerogel as insulation materials in protective clothing especially for fire fighters at higher temperature. In past, aerogels were employed for insulation of buildings, aeronautics and aerospace applications. Later on, researchers determined the utility of aerogels as insulated substrate in protective clothing. Several investigations revealed insulation properties of aerogel at elevated temperature. There are several different types of aerogel but in this article, the main emphasis is on silica based aerogel because of its excellent insulation and outstanding flame proof properties along with thermal stability at raised temperature. By applying suitable coating techniques, aerogel can be impregnated into nonwoven substrates, which can be employed as thermal barriers resulting in enhancement of the protective capability of multilayered clothing at higher temperature. All these characteristics make aerogel a potential candidate to be used as insulation material in protective clothing at elevated temperature.

Keywords: aerogels, thermal insulation, thermal conductivity, protective clothing

\section{INTRODUCTION}

The discovery of silica based aerogels in 1930s by Samuel Stephens Kistler was based on concept of substituting the liquid phase with the gaseous phase along with little amount of shrinkage and without crumpling of gel solid network. Aerogels are smoked like substrates having resemblance of hologram and instead of appearing as solid material it looks like projection. Aerogels are synthesized by Sol-Gel process which is simple, cost effective and delivers high quality substrates [2].

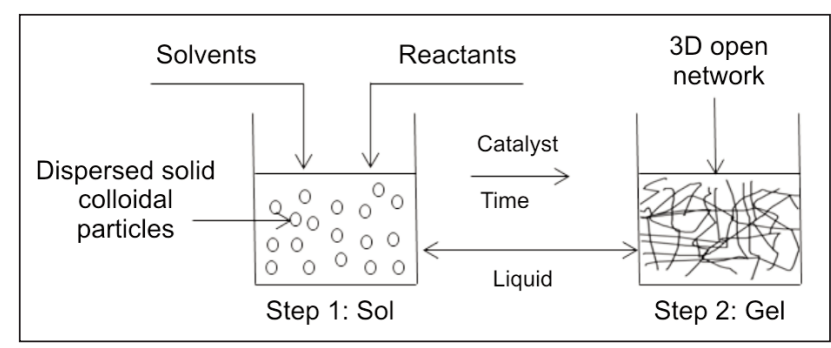

Fig. 1. Process of Sol-Gel [3]
In this method, a chemical reaction was carried out in a solution at low temperature to produce inorganic network or creation of an amorphous structure from the solution. The distinct feature of this reaction was conversion from colloidal solution to di-or multiphase gel. Silica based aerogels have $96 \%$ of air and $4 \%$ of silicon dioxide, making silica based aerogels as one of the lightest weight solid substrates [1]. A sol is a colloidal suspension of solid particulates in an aqueous medium in which range of dispersion phase is from $(1-1000 \mathrm{~nm})$ [3]. Sol can be synthesized either by condensation or dispersion of particulates. Condensation occurs when nucleation development of particulates approaches adequate size. However, dispersion includes breaking of large particulates to colloidal sizes. In case of gelatin process, a free flowing sol is transformed into a three dimensional solid structure encapsulating the solvent media. It was evident that liquid does not permit the solid structure to crumple and solid structure does not allow the liquid to move out. Figure 1 depicts the schematic diagram of Sol-Gel process [3-4]. 


\section{STEPS INVOLVED IN SOL GEL PROCESS}

Three steps required for sol gel process are:

a. Formation of gel

b. Aging

c. Drying

\section{Formation of gel}

Mostly precursors utilized for sol-gel process are silicon alkoixdes which are available in high degree of purity. However it is very difficult to purify potassium silicate [4]. One of the most important precursors of silica based aerogel is sodium meta-silicates and it was primarily employed by Kistler for synthesizing silica aerogels [5]

$\mathrm{Na}_{2} \mathrm{SiO}_{3}+2 \mathrm{HCl}+(x-1) \mathrm{H}_{2} \mathrm{O} \rightarrow \mathrm{SiO}_{2} \cdot x \mathrm{H}_{2} \mathrm{O}+2 \mathrm{NaCl}$

The preparatory materials for the sol-gel process must be soluble in reaction medium and sufficiently reactive to have contribution in the gel-creating process. All of these preparatory substrates are described by the existence of $\mathrm{Si}-\mathrm{O}$ polar covalent bonds [6]. The covalent nature of the $\mathrm{Si}-\mathrm{O}$ bond is adequate to allow distribution of $\equiv \mathrm{Si}-\mathrm{O}-\mathrm{Si} \equiv$ angle values creating a three dimensional structure in random manner which resembles structure of silica glass. Hydrolysis can be catalyzed via acid catalysis or base catalysis. Acids like $\mathrm{HCl}, \mathrm{HNO}_{3}, \mathrm{H}_{2} \mathrm{SO}_{4}, \mathrm{HF}$, oxalic, formic and acetic acid are employed for acid catalysis. When $\mathrm{pH}$ of solution is less, the time period for gelatin formation is normally elongated [4] According to Dieudonne et al. [7] base catalysis is a simple procedure in which there is an easy formation of network of uniform particles in the solution and the subsequent pore volume is significantly enhanced.

\section{Aging}

During aging, a neck growth due to reprecipitation of silica deliquesces from the surface of particle upon necks between particles and smaller particles dissolute and conversion into bigger ones by precipitation [8]. The purpose of this step is to mechanically reinforce the weak solid skeleton generated during solgel process [4].

\section{Drying}

In case of drying, the most commonly used method is Super Critical Drying method. This method is governed by evacuation of pore liquid above the critical temperature $\left(T_{c}\right)$ and critical pressure $\left(P_{c}\right)$. At this instant, there is no liquid-vapor boundary and consequently there is no capillary pressure. This procedure is completed in three stages [9]: In first step, wet gel along with appropriate quantity of solvent is set in an autoclave by steadily elevating the temperature. This will result in escalation of pressure. Temperature and pressure of the concerned solvent are attuned to acquire values above critical points. In second step, the fluid is gradually expelled at constant temperature causing decrease in pressure. In third step, the temperature of vessel drops to room temperature once

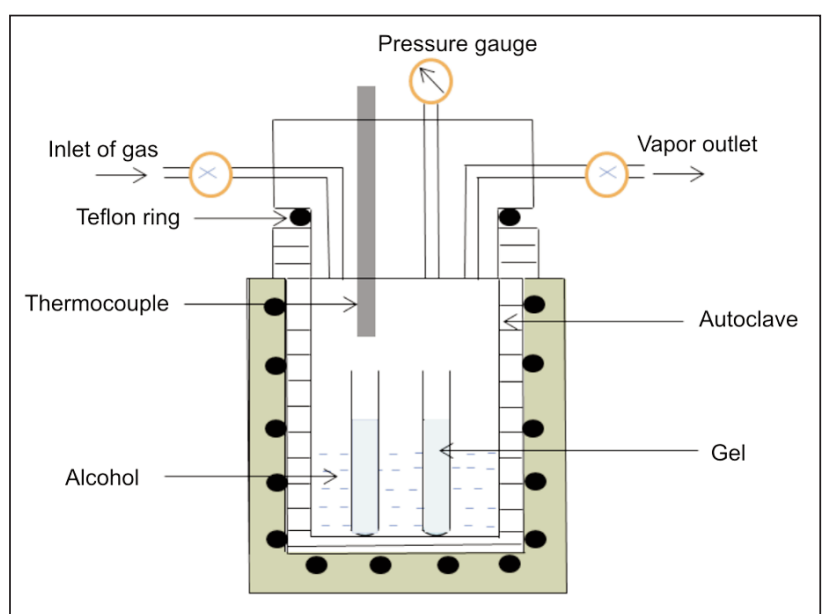

Fig. 2. Schematic representation of supercritical drying autoclave [6]

ambient pressure is acquired. Figure 2 depicts autoclave for performing supercritical drying. Drying can also takes place via ambient pressure drying and freeze drying [10].

\section{PROPERTIES AND UTILITIES OF SILICA BASED AEROGELS}

\section{Structure of pore}

Silica based aerogels are mostly mesoporous having interlocked pore size with range from 5 to $100 \mathrm{~nm}$. The diameter of average pore is between 20 to $40 \mathrm{~nm}$. Micropores having pore size less than $2 \mathrm{~nm}$ becomes pertinent in aerogels produced under acidic catalysis conditions [11]. The specific surface range from 250 to $800 \mathrm{~m}^{2} \mathrm{~g}^{-1}$ and can surpass $1000 \mathrm{~m}^{2} \mathrm{~g}^{-1}$.

\section{Thermal insulation, flame proof property}

Silica based aerogels have very small portion of solid silica (nearly $1-10 \%$ ) due to which they have lesser solid conductivity and thus exchange lesser thermal energy [4]. At ambient pressure, temperature and relative humidity, silica based aerogels have very low thermal conductivity of the order $0.015 \mathrm{~W} / \mathrm{mK}$ which is expressively lesser than thermal conductivity of air $(0.025 \mathrm{~W} / \mathrm{mK})$ under same circumstances [12]. Apart from having thermal insulation property, silica aerogel has remarkable flame proof property [13]. By means of mass, Aerogel is $99.8 \%$ air making it least dense man-made substrate [14]. Aerogel can abrogate all three modes of heat transfer. Conductive heat transfer is blocked because of gaseous structure of aerogel and thermal conductivity of gas is very low. The gaseous structure of aerogel is derived from its porous construction. Convective heat transfer is averted because structure of aerogel does not allow circulation of air. Infrared radiation that plays role in transference of heat can also be absorbed by aerogel. As consequence, aerogel can function as outstanding thermal insulator [15].

\section{Sorption and entrapment properties}

Aerogels can be utilized to adsorb some chemical compounds i.e. waste water treatment for restricting 
radioactive waste or for filtration of gases. Silica aerogels soaked with $\mathrm{CaCl}_{2}$, $\mathrm{LiBr}$ and $\mathrm{MgCl}_{2}$ salts have also been confirmed to absorb/adsorb water for retention of heat at low temperature [16]. It was suggested hollow silica aerogel droplets for inertial entrapment of fluids, specifically blends of liquid deuterium and tritium, as the aim in fusion experimentation under very strong laser. Bacteria can also be successfully entrapped in aerogels while remaining alive.

\section{HEAT EXCHANGE PROCESS}

Heat exchange equation illustrates transfer of heat in porous substrates like aerogels [17].

$$
\nabla \vec{q}+\Phi=\rho \cdot c \cdot \frac{\partial T}{\partial t}
$$

This equation depicts law of conservation of energy by balancing heat fluxes across interfaces of infinite volume. In the above equation $q$ is the heat flux density, $\rho$ - the density and is the specific heat, $\Phi-$ the heat source and $T$ - local temperature.

$$
\vec{q}=-k \nabla T
$$

$k$ is three dimensional tensor of the thermal conductivity. This equation is the Fourier law which narrates that heat flux density is proportional to local temperature difference and describes the thermal conductivity $k$. The heat source $\Phi$ explains the impact of phase changes or sorption phenomenon within an aerogel associated with the discharge or intake of reaction enthalpies and increase or decrease of thermal radiation. Thermal radiation is explained by heat source term in following way:

$$
\Phi=\nabla \vec{q}_{r}
$$

Here $q_{r}$ is radiative heat flux density. In case of isotropic aerogel and when heat exchange is dependent only on local temperature difference:

$$
\Delta T=\frac{1}{\alpha} \cdot \frac{\partial T}{\partial t}
$$

Where $\alpha$ is the thermal diffusivity which is equal to $k /(\rho \cdot c)$. In this situation, experimentally evaluated thermal conductivity is characteristics of the substrate. Where $\rho^{*} c$ is termed as volumetric specific heat and is suitable for the situation of nonstationary heat exchange where temperature and heat fluxes varies with time [12, 18].

\section{APPLICATIONS OF SILICA AEROGELS AT HIGH TEMPERATURE}

At present the most common utility of aerogel products are in oil and gas pipelines, building insulations along with aeronautics/aerospace and high temperature applications [19]. On commercial bases aerogel is available asNanogel ${ }^{\mathrm{TM}}$, which can be employed as superinsulating filling substrates; however CABOT is also supplying Nanogel ${ }^{\mathrm{TM}}$ based components like Thermal wrap ${ }^{\mathrm{TM}}$ and Compression pack ${ }^{\mathrm{TM}}$ for special applications like pipe in pipe and cryogenic insulation systems. Apart from that, ASPEN company is providing blanket-based products for insulation of building on commercial scale and also developing products for utility in acute hot and cold climates (pyrogel and cryogel) [18-19]. Novel advancements of aerogel science have made it viable to create more flexible aerogels in simplified ways. All these features make aerogel favorable prospects to be utilized for enhancing thermal protection and thermal insulation in fire fighter protective clothing.

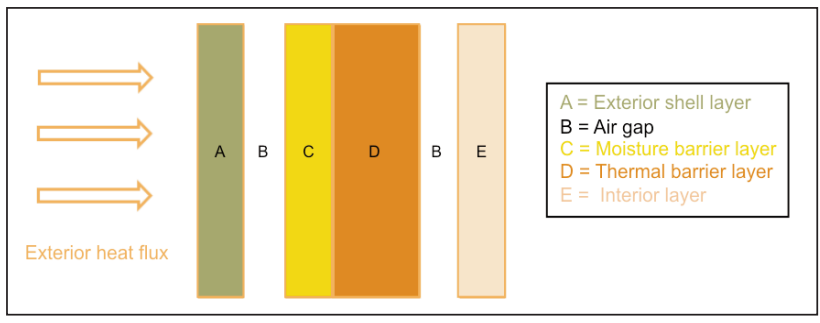

Fig. 3. Configuration of fire fighter clothing assemblies [22]

Fire fighters are subjected to several threats with respect to their working atmosphere. In addition to numerous toxic ingredients in the surrounding atmosphere, extreme radiant heat fluxes and hot flames are probable hazards in fire extinguishing activity. Thermal protective performance of fire fighter protective clothing is of huge significance to the lives of firefighters [20].

The key purpose of fire fighter clothing is to decline the rate of heat accumulation in human skin so as to give time for the firefighter to respond and avert or reduce skin burn injury [21]. Mostly fire fighter protective clothing comprised of three layers such as exterior shell, middle layer and interior layer or two layers like outer shell and inner layer with assembly of moisture barrier and a thermal barrier as shown in figure 3 [22]. The exterior layer averts body skin from hazards of heat radiation or flame and intermediate layer delivers execution of waterproof and heat insulation. Mostly the aramid fibers are utilized for insulation layer and PTFE membranes are employed as breathable waterproofing layer. Jin et al. investigated thermal protective behavior of nonwovens employed with aerogels [21]. It can be noticed that specimen coated with aerogels had greater LOI values than the untreated specimen. This might be due the fact that inorganic aerogel particles being attached on the surface of specimen might enhance the flame retardant characteristics [21]. For evaluation of effect of aerogel on thermal protective performance (TPP) of the whole fire fighter garment, aerogel treated firefighter clothing utilizing thermal liner in fighter protective garment was developed by Jin et al. [22]. Instrumented manikin system under heat flux density of $84 \mathrm{~kW} / \mathrm{m}^{2}$ with 8 second of exposure time was employed. For aerogel treated fire fighter clothing, total burn injury was $12.7 \%$ which was lesser than that of existing 
garment which was $25.1 \%$ [22]. It was also witnessed that aerogel impregnated sample when utilized next to skin can absorb moisture and discharge it ambient surrounding with great ease. Moreover there was increase in the rate of moisture absorption when aerogel impregnated layer was employed next to skin [22]. Thus it was deduced that aerogel when coated on textile substrate can enhance thermal resistance of the fabric and delivers better thermal insulation properties.

\section{CONCLUSION}

Aerogels are invented long time ago but its application in daily life started a decade ago. The application of aerogels for insulation at higher temperature is still an open field and needs to be researched deeply. In this report the application of aerogels specially for insulation properties are discussed and will be a basis for continuing research related to use for aerogels in firefighter clothing, fire protection buildings and facade insulation. With extremely low thermal conductivity and high porosity the aerogels have a great future for the application for insulation at higher temperature. Another open field of aerogels is also comfort properties and could be a great application for clothing for protection with comfort requirement. The breathe ability of aerogels can play an important role for the comfort and insulation application.

\section{ACKNOWLEDGMENT}

This study is supported under student grant scheme of SGS-21200.

\section{BIBLIOGRAPHY}

[1] Patel, R., Purohit, N., Suthar, A. An overview of silica aerogels.In: International Journal of ChemTech Research, 2009, vol. 1, no. 4, pp. 1052-1057.

[2] Chakraborty, S., Pisal, A.A., Kothari, R. Synthesis and characterization of fiber reinforced silica aerogel blankets for thermal protection. In: Advances in Materials Science and Engineering, 2016, pp. 1-8.

[3] Pierre, A.C., Pajonk, G.M. Chemistry of aerogels and their applications. In: Chem. Rev, 2002, vol. 199, pp. 4243-4266.

[4] Soleimani, D.A., Abbasi, M.H. Review silica aerogel; synthesis, properties and characterization. In: Journal of materials processing technology, 2008, vol. 199, pp. 10-26.

[5] Venkateswara, R.., Parvathy, R.A., Kulkarni, M.M. Influence of gel aging and $\mathrm{Na}_{2} \mathrm{SiO}_{3} / \mathrm{H}_{2} \mathrm{O}$ molar ratio on monolithicity and physical properties of water-glass-based aerogels dried at atmospheric pressure. In: J Non-Cryst Solids, 2004, vol. 350, pp. 224-229.

[6] Brinker, C., Scherer, G. Sol-gel science. In: The physics and chemistry of sol-gel processing, Academic Press, New-York, 1990, vol. 97, pp. 461-523.

[7] Wu, G., Wang, J., Shen, J., Yang, T., Zhang, Q., Zhou, B., Deng, Z., Bin, F., Zhou, D., Zhang, F. Properties of sol gel derived scratch resistant nano porous silica films by mixed atmosphere treatment. In: J. Non-Cryst Solids 2000 , vol. 275, pp. 169-174.

[8] Strøm, R.A., Masmoudi, Y., Rigacci, A., Petermann, G., Gullberg, L., Chevalier, B., Einarsrud M.A. Strengthening and aging of wet silica gels for up-scaling of aerogel preparation. In: J Sol Gel SciTechnol, 2007, vol. 41, pp. 291-298.

[9] Reichenauer, G.J., Proceedings of $7^{\text {th }}$ international Symposium on Aerogels. In: Non-Crystal Solids, 2004, vol. 350, pp. 189-195.

[10] Suh, D.J., Park, T.J., Sonn, J.H., Lim, J.C. Effect of aging on the porous texture of silica aerogels prepared by $\mathrm{NH}_{4} \mathrm{OH}$ catalyzed sol-gel process. In: J Mater SciLett, 1999, vol. 18, pp. 1473-1475.

[11] Husing, N.,Schubert, U. Aerogels - Airy materials: Chemistry, structure, and properties. In: AngewChemInt Ed, 1998, vol. 37, pp. 23-45.

[12] Yoldas, B.E., Annen, M.J., Bostaph, J. Chemical engineering of aerogel morphology formed under nonsupercritical conditions for thermal insulation. In: Chem Mater 2000, vol. 12, pp. 2475-2484.

[13] Bheekhun, N., Talib, A.R.A., Hassan, M.R. Aerogels in aerospace: an overview. In: Advances in Materials Science and Engineering, 2013, pp. 1-18.

[14] Soleimani, D.A., Abbasi, M.H. Silica aerogel; synthesis, properties and characterization. In: Journal of Materials Processing Technology, 2008, vol. 199, pp. 10-26.

[15] Shahid, A., Wang, L., Padhye, R. The thermal protection and comfort properties of aerogel and PCM-coated fabric for firefighter garment, 2016, vol. 45(4), pp. 611-625.

[16] Aristov, Y.I., Restuccia, G., Tokarev, M.M., Cacciola, G. Selective water sorbents for multiple applications, 10. In: Energy Storage Ability. ReactKinetCatalLett, 2000, vol. 69, pp. 345-353.

[17] White, J.F. Silica aerogel: Effect of variables on its thermal conductivity. In: Industrial and Engineering Chemistry, 1939, vol. 31, pp. 827-831.

[18] Bankvall, C.G., Natural convection in vertical permeable space. In: W€arme- und Stoff€ubertragung, 1974, vol. 7, pp. 22-30. 
[19] Koebel, M.M., Rigacci, A., Achard, P. Aerogels for superinsulation: A synoptic view. In: Aegerter, M.A, Leventis, N., Koebel, M., editors. Aerogels Handbook, Advances in Sol-Gel derived materials and technologies. New York: Springer Dordrecht Heidelberg London, 2011, pp. 625-630,

[20] Onofrei, E., Dupont, D., Petrusic, S., Soulat, D., Bedek, S., Codau, T.C. Modeling of heat transfer through multilayer firefighter protective clothing. In: Industrial Textila, 2014, vol. 65, pp. 277-282.

[21] Jin, L., Hong, K., Yoon, K. Effect of aerogel on thermal protective performance of fire fighter clothing. In: Journal of Fiber Bioengineering and Informatics, 2013, vol. 6, pp. 315-324.

[22] Jin, L., Hong, K., Nam, H.D., Yoon, K. Effect of thermal barrier on thermal protective performance of firefighter clothing. In: Journal of Bioengineering and Informatics, 2011, vol. 4, pp. 245-252.

Authors:

JAWAD NAEEM ${ }^{1}$

ADNAN MAZARI ${ }^{1}$

ENGIN AKCAGUN 2

ZDENEK KUS ${ }^{1}$

${ }^{1}$ Technical University of Liberec, Faculty of Textile Engineering, Department of Clothing Studentska 2, Husova, 1402/2, Liberec, Czech Republic

e-mail: jawadnaeem.qau@gmail.com, adnanmazari86@gmail.com,zdenek.kus@tul.cz

${ }^{2}$ Mimar Sinan Fine Arts University, Istanbul, Turkey

e-mail: enginakcagun@gmail.com

Corresponding author:

JAWAD NAEEM

e-mail: jawadnaeem.qau@gmail.com 


\section{Nanofibres made from biocompatible and biodegradable polymers, with potential application as medical textiles}

\section{REZUMAT - ABSTRACT}

Nanofibre obținute din polimeri biocompatibili și biodegradabili, cu potențial de utilizare ca textile medicale

O parte importantă și în continuă dezvoltare a industriei textile este sectorul medical și cel conex, de igienă și îngrijire a sănătății. Recent, vălurile de fibre ultrafine obținute din polimeri biocompatibili și biodegradabili au fost obținute prin procesul de electrofilare. Proprietățile lor unice, cum ar fi raportul dintre suprafața mare și volum, dimensiunile mici ale porilor, porozitatea ridicată și posibilitatea introducerii compușilor terapeutici în nanofibrele electrofilate, au atras atenția cercetătorilor în ultima vreme. Această lucrare prezintă obținerea nanofibrelor PEO și PVA.

Cuvinte-cheie: electrofilare, nanofibră, văl de fibre, poli (alcool vinilic), poli (oxid de etilenă)

\section{Nanofibres made from biocompatible and biodegradable polymers, with potential application as medical textiles}

An important and growing part of the textile industry is the medical and related healthcare and hygiene sector. Recently, ultrafine fiber webs made from biocompatible and biodegradable polymers have been obtained by the electrospinning process. Their unique properties such as high surface area-to-volume ratio, small pore sizes, high porosity, and the possibility of incorporation therapeutic compounds into the electrospun nanofibers has attracted the researcher's attention lately. This paper presents the obtaining of PEO and PVA nanofibers.

Keywords: electrospinning, nanofiber, web, poly (vinyl alcohol), poly (ethylene oxide)

\section{INTRODUCTION}

Electrospinning is one of the most widely used techniques in the 21 st century, due to its adaptability and potential for applications in various domains, such as: wound healing, artificial skin, membranes for selective separation, target delivery system for active agents and molecules, scaffolds for tissue or bone engineering $[1,8]$. Tissue engineering strategies are based on biological, medical and engineering disciplines, and aims to repair and regenerate damaged tissues or organs that no longer function properly. This is often achieved by development of a 3D porous matrix with similar biomechanical properties, enhanced with elements that sustain and promote tissue regeneration. Fibrous materials of submicron dimensions are potentially better candidates in skin wound treatment, when compared with normal dressing materials, such as cotton pads and bandages, due to a number of advantageous properties, including high porosity ratio, high permeability, biocompatibility and biodegradability [7].

Electrospinning represents one of most important process through which tailoring the material structure at nanometer scale becomes possible [2, 6]. Electrospinning uses an electrical field to create a charged jet of a polymer solution. At a critical voltage, the repulsive force overcomes the surface tension of the solution and a jet erupts from the tip of the capillary towards a grounded collector. The voltage applied is usually between 7 and $30 \mathrm{kV}$ [3].

According to their purpose of usage, for which they have been selected, quick or slow degrading polymers can be used to generate nanofibres $[9,11,13]$. Polymers that have a longer degradation time offer better structural and mechanical support and can be effectively used for procedures like dialysis, tissue engineering and drug delivery systems. In contrast, polymers that are quickly degradable in vivo (due to enzymatic and hydrolytic activities) do not interfere with cellular activities and allow for the cell proliferation through the spaces created by the degraded fibers, that allow extracellular matrix to infiltrate and provide nutrition for the proliferating cells. The main characteristics of polymers, which compete in their selection, are: elasticity, resilience, presence of functional groups, etc. [4, 10, 14].

Many compounds for therapeutic purpose can be incorporated within nanofibers, by using two different methods. The simplest method is by blending, where the drug molecules and the polymer are miscible and electrospun together. The second possibility is to encapsulate the drug in micro-capsules or to conduct a core-shell electrospinning, to form drugs encapsulated in fibers. In order to generate a core shell structure a coaxial spinneret is needed $[4,5]$.

One of the main areas of research in biomedical application of electrospinning is drug delivery where the electrospun fiber releases the therapeutic agent 
in the specific environment in which it is used. In addition, electrospun fibers maintain the integrity and bioactivity of the drug molecules due to the mild processing parameters [12]. Localized delivery of therapeutic compounds can significantly reduce the systemic absorption of the drug and reduce any side effects. In addition, the efficacy of the drug is also improved, due to localization of the treatment [4, 7].

\section{EXPERIMENTAL WORK}

Electrospun nanofiber web of poly (ethylene oxide) (PEO) and poly (vinyl alcohol) (PVA) were successfully prepared. The fibers, of 200-300 nm in diameter, were obtained by regulating the main parameters: solution concentration, the electric voltage, and the distance between the injection needle tip and the fiber collector. The fiber meshes were analyzed by scanning electron microscopy (SEM), which showed the properties of the fibers, such as: the diameter of the nanofibers, the regularity of the nanofiber shape, and the uniformity of the diameter.

\section{Materials}

PEO with an average molecular weight and PVA with $80 \%$ hydrolization degree was purchased from Sigma Aldrich and used as supplied. The concentration used for the electrospinning of the polymers was varied between 1,5 and $15 \%(\mathrm{w} / \mathrm{v})$ until electrospinning has occurred.

\section{Method for electrospinning the prepared solution}

The fibers were electrospun with a flow rate of 0.8-2 $\mathrm{ml} / \mathrm{h}$ and a voltage of $10-18 \mathrm{kV}$ and a distance of 15-20 cm between the needle and the grounded collector. Those conditions were experimentally optimized to obtain bead-free nanofibers and to have stable processing conditions.

PVA fibers obtained in this study were smooth and randomly oriented, without beads, with diameter range

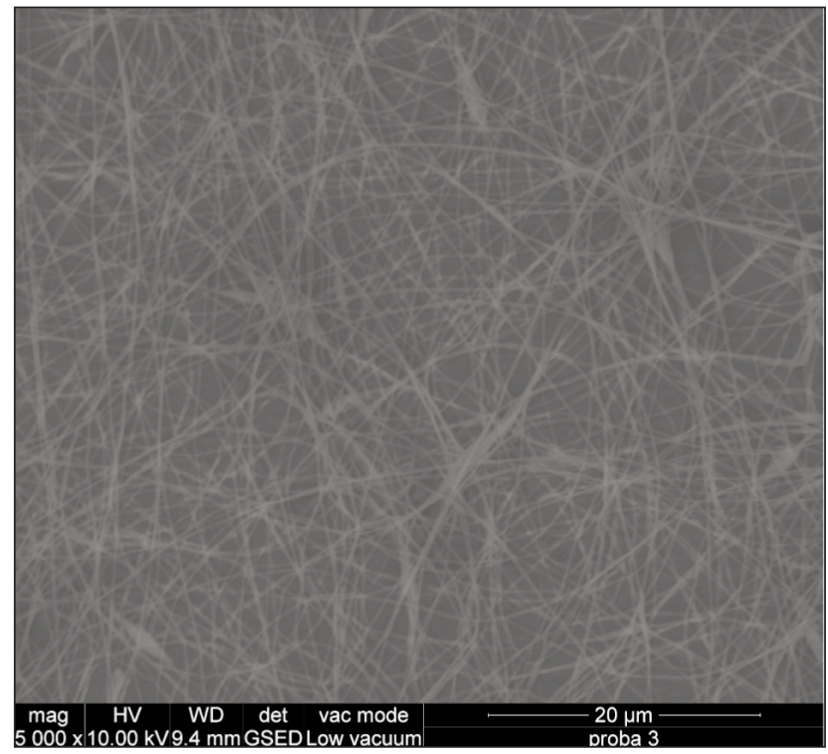

Microscopic SEM image of PEO nanofibers

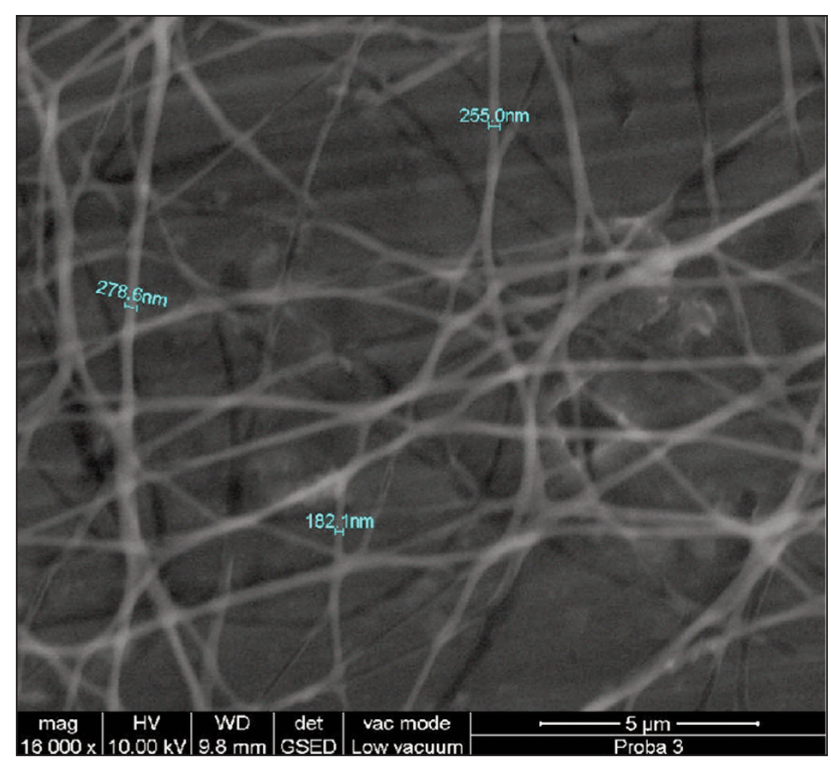

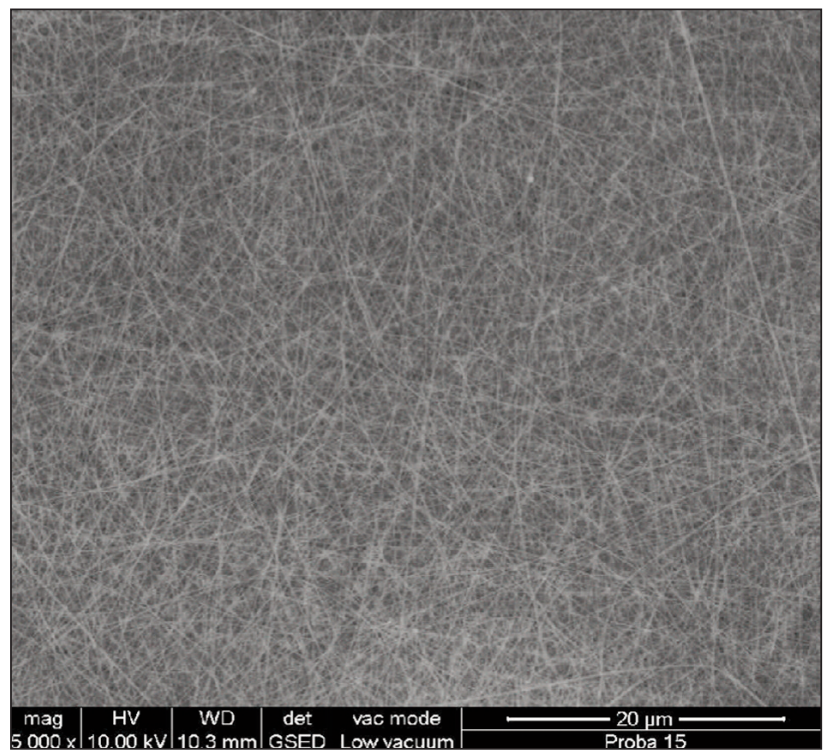

Microscopic SEM image of PVA nanofibers

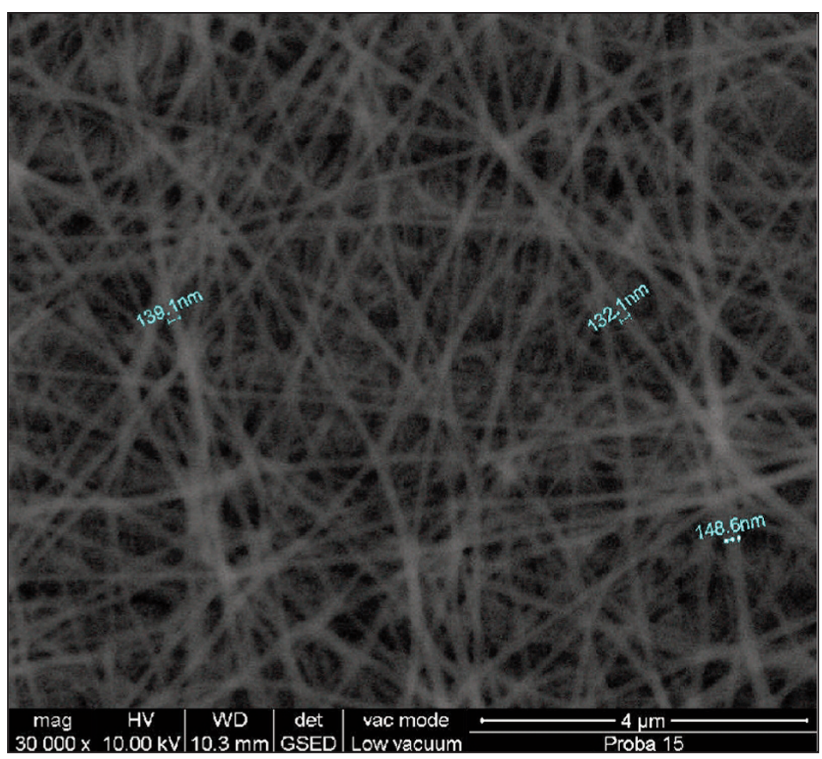

Fig. 1. SEM Images of PEO and PVA nanofibers 
from 200 nanometers to $300 \mathrm{~nm}$. For PEO fibers, beads have been noticed on the surface.

The experimental apparatus uses a high voltage power supply, a syringe pump and a collector system. The maximum allowed voltage was $30 \mathrm{kV}$. The flow rate was controlled by the syringe pump. The fibres were collected on a grounded metal collector plate of a rectangular base covered with cotton gauze. The electric field was applied between the syringe needle and the metal collector plate (grounded). The electric voltage was incremented until the fibre spinning was observed. The electric field can be changed by varying the distance between the syringe needle and the collector plate.

\section{Methods for structural characterization}

SEM Analysis - The surface aspect of the resulting porous webs were studied using a scanning electron microscope at an accelerating voltage of $10 \mathrm{kV}$. SEM photographs were taken at different magnification by using Quanta FEI SEM equipment.

The nanofibers surface wettability was assessed through the method of determining the contact angle of drops of distilled water that are placed on the surface of the web.

\section{RESULTS AND DISCUTION}

The nanofibres obtained using electrospinning processes are collected as a web by consecutive deposition of layers of randomly aligned nanofibers. Although the fibres cover primarily the metallic collector, a considerable quantity falls outside of the collector.

\section{Nanofiber morphology}

The characterization of PVA and PEO nanofibers was performed by using a $\mathrm{FEI}$ Scanning Electron Microscope at $10 \mathrm{kV}$ voltages. The SEM images are given in figure 1.
The PEO solution has conducted to a random deposition of the nanofibres. Few beads are noticed to be present within the structure, produced at the beginning of the experiment, until a laminar flow of polymeric solution has been obtained. The fibre diameter varies between 182-280 $\mathrm{nm}$.

In contrast, the PVA solution produced a structure of relatively more organized layers, without beads, with fiber diameters in rage of 132-149 nm.

Both structures can be present a dense network of pores of different sized, highly interconnected.

\section{Surface wettability}

The surface water absorption capacity was assessed through the method of contact angle, by placing drops of distilled water on the surface of the web. The equipment used was VCA Optima. No contact angle could be measured, as the water absorption was instantly.

\section{CONCLUSIONS}

Electrospinning was used to fabricate nanofibres of PVA and PEO. The effect of processing parameters such as voltage, tip-collector distance and flow rate on fiber diameter and its morphology has been evaluated. The morphology of fibers and their diameters were strongly influenced by the composition of the solution and the applied tension. The porous structure of the electrospun webs obtained, the biocompatibility and biodegradability of the polymers used make our electrospun scaffold an excellent candidate for biomedical applications. In vitro and in vivo experiments for evaluation of the biocompatibility of these PEO and PVA nanofibers is necessary.

\section{ACKNOWLEDGMENTS}

This paper was achieved through Nucleus Programme, conducted through the financial support of ANCSI, project PN 16340204 .

\section{BIBLIOGRAPHY}

[1] Nitilaksha Hiremath, and Gajanan Bhat, Melt blown Polymeric Nanofibers for Medical Applications - An Overview, Nanoscience \& Technology: Open Access, available at: https://symbiosisonlinepublishing.com/nanosciencetechnology/nanoscience-technology25.pdf.

[2] S. Liao, C. K. Chan, S. Ramakrishna, Electrospun nanofibers: Work for medicine? In: Front. Mater. Sci. China 2010, 4(1), pp. 29-33

[3] Miriam Haerst, Vera Seitz, Markus Ahrens, Cécile Boudot, and Erich Wintermante, Silicone Fiber Electrospinning for Medical Applications, In: 6th European Conference of the International Federation for Medical and Biological Engineering, IFMBE Proceedings, 2015, available online at: https://link.springer.com/chapter/10.1007/978-3-31911128-5_134.

[4] Nishath Khan, Applications of electrospun nanofibers in the biomedical field, In: Studies by Undergraduate Researchers at Guelph, vol. 5, no. 2, 2012, pp. 63-73.

[5] A.C. Baptista, I. Ferreira and J.P. Borges, Electrospun Fibers in Composite Materials for Medical Applications, In: Journal of Composites and Biodegradable Polymers, 2013, 1, pp. 56-65.

[6] L.R. Manea et al, Recent advances of basic materials to obtain electrospun polymeric nanofibers for medical applications, In: IOP Conf. Series: Materials Science and Engineering 145 (2016) 032006.

[7] Anhui Wang, Chao Xu, Chuanwei Zhang, Yunna Gan, and Bin Wang, Experimental investigation of the properties of electrospun nanofibers for potential medical application, In: Journal of Nanomaterials, Volume 2015 (2015), Article ID 418932, available at: https://www.hindawi.com/journals/jnm/2015/418932/ 
[8] Haifeng Liu, Xili Ding, Gang Zhou, Ping Li, Xing Wei, and Yubo Fan, Electrospinning of nanofibers for tissue engineering applications, In: Journal of Nanomaterials, Volume 2013 (2013), Article ID 495708, available at: https://www.hindawi.com/journals/jnm/2013/495708/

[9] Nuno M Neves, Rui Campos, Adriano Pedro, José Cunha, Francisco Macedo, Rui L Reis, Patterning of polymer nanofiber meshes by electrospinning for biomedical applications, In: International Journal of Nanomedicine 2007:2(3), pp. 433-448.

[10] Moustafa M. Zagho and Ahmed Elzatahry, Recent trends in electrospinning of polymer nanofibers and their applications as templates for metal oxide nanofibers preparation, available at: https://cdn.intechopen.com/pdfswm/53008.pdf

[11] Bara, A., Marinescu, V., Chitanu, E., Banciu, C., Clicinschi, F., Influence of process parameters on the morphology of polyacrylonitrile electrospun fibers, In: Industria Textila, 2015, vol. 66, nr. 4, pp. 232-239.

[12] A. Shankar, A-F Seyam, S. Hudson, Electrospinning of soy protein fibers and their compatibility with synthetic polymers, In: Journal of Textile and apparel Technology and Management, vol. 8, Issue 1, 2013.

[13] R. Dersch, M. Steinhart, U. Boudriot, A. Greiner and J. H. Wendorff, Nanoprocessing of polymers: applications in medicine, sensors, catalysis, photonics, In: Polymers for Advanced Technologies, 2005; 16, pp.276-282

[14] Banciu, C., Bara, A., Chitanu, E., Lungulescu, M., Ion, I., Leonat, L., Filtering membranes based on electrospun expanded polystyrene/ $\beta$-cyclodextrin fibers, In: 10th International Symposium on Advanced Topics in Electrical Engineering (ATEE), March 23-25, 2017, Bucharest, Romania, IEEE, pp. 223-226.

Authors:

\section{ADRIANA-IOANA SUBTIRICA ${ }^{1}$ CRISTINA ANTONELA BANCIU2 ANDREEA ANA-MARIA CHIVU 1 LAURENTIU CHRISTIAN DINCA}

${ }^{1}$ The Research-Development National Institute for Textile and Leather, Textile Division 16 Lucretiu Patrascanu street, 030508, Bucharest, Romania

e-mail: adriana.subtirica@certex.ro

${ }^{2}$ National Institute for Research and Development in Electrical Engineering INCDIE ICPE-CA

313 Splaiul Unirii, 030138, Bucharest, Romania

e-mail: cristina.banciu@icpe-ca.ro

Corresponding author:

ADRIANA-IOANA SUBTIRICA

e-mail: adriana.subtirica@certex.ro 


\title{
Application of 3D-TO-2D garment design for atypical morphology: a design case for physically disabled people with scoliosis
}

\author{
DOI: 10.35530/IT.069.01.1377
}

YAN HONG

PASCAL BRUNIAUX

JUNJIE ZHANG

KAIXUAN LIU MIN DONG YAN CHEN

\section{REZUMAT - ABSTRACT}

\section{Aplicații ale proiectării îmbrăcămintei 3D-2D pentru morfologia atipică: un caz de proiectare pentru} persoanele cu dizabilități fizice cu scolioză

\begin{abstract}
Metoda de proiectare a îmbrăcămintei 3D-2D apare ca o soluție nouă pentru proiectarea și producția automată de îmbrăcăminte, în special pentru consumatorii cu morfologie atipică. În această lucrare s-a introdus un caz de aplicare a proiectării unui articol personalizat de îmbrăcăminte pentru persoanele cu dizabilități fizice, cu scolioză (PDPS), utilizând metoda de proiectare 3D-2D. Se propune un model îmbunătătit pentru a satisface cerința de automatizare a proiectării. Modelul propus se bazează pe evaluarea rezultatului de probare virtuală $3 D$ utilizând cunoștințele profesionale ale designerilor. Rezultatele cercetării arată că proiectarea îmbrăcămintei 3D-2D poate realiza în mod eficient o proiectare personalizată pentru morfologia atipică. De asemenea, utilizând evaluarea senzorială, cunoștințele profesionale de design pot fi aplicate pe deplin pentru a controla spațiul tehnic $2 D$ al proiectării îmbrăcămintei pe baza percepției rezultatului de probare virtuală a îmbrăcămintei $3 D$.
\end{abstract}

Cuvinte-cheie: morfologie atipică, proiectare virtuală, 3D-2D, proces pe bază de cunoștințe

Application of 3D-to-2D garment design for atypical morphology: a design case for physically disabled people with scoliosis

$3 D$-to-2D garment design method emerges as a novel design solution for automatic garment design and production, especially for consumers with atypical morphology. In this paper, we introduced an application case of designing a personalized garment for physically disabled people with scoliosis (PDPS) using 3D-to-2D garment design method. A pattern modification model is proposed in order to satisfy the requirement of design automation. The proposed modification model is based on the evaluation of the $3 D$ virtual try-on result using the professional knowledge of the designers. Research results indicate that 3D-to-2D garment design can effectively realize personalized design for atypical morphology. Also, using sensory evaluation, professional design knowledge of the designers can be fully applied to control the 2Dtechnical space of garment design based on the perception of $3 D$ garment virtual try-on result.

Keywords: atypical morphology, virtual design, 3D-to-2D, knowledge-based process

\section{INTRODUCTION}

With the development of 3D laser body scan and surface reconstruction technology, designing a garment directly on a 3D scanned body using virtual reality and 3D CAD technology emerges as a novel design solution for fashion industry. Currently, the 3D method consists of several design phases, which include 3D scanning, digitalized 3D body modeling, 3D garment generation, interactive 3D garment surface modeling and pattern design [1]. Compared with traditional design method such as traditional 2D-to-3D method, virtual reality based $3 D-t o-2 D$ design method is proved to be able to effectively satisfy the personalized garment design for atypical morphology [2]. However, 3D garment simulation is rather time costing and requires of high-level technical support of the software operation. What is more, due to the diversity of garment style, it is difficulty to define a systematic design rule for designing ready-to-wear products of all kind of styles using 3D-to-2D design method [3]. To solve this problem, in our previous study, we developed an interactive virtual try-on based 3D garment block design for physically disabled people of scoliosis type (PDPS) [1]. A personalized garment block is designed for PDPS with controlled wearing ease. Using this block, 2D garment patterns of the desired ready-to-wear products can be extended from the proposed garment block pattern. In this paper, based on previous study, we introduced an application case of designing a ready-to-wear garment using the garment block design from 3D-to-2D design method in order to validate the applicability of 3D-to-2D design method. Using personalized garment block, all kinds of garment style can be realized very fast in $2 \mathrm{D}$ environment, which can be easily controlled by designers compared with designing in 3D environment [5-6]. In this research, a perception-based pattern modification model is proposed on the basis of a collaborative design process. Perceptual data of consumers on the desired product is extracted and analyzed by the knowledge and experience of designers using an interactive procedure. Sensory analysis (or sensory evaluation) is a scientific discipline that makes use of human senses (sight, smell, taste, touch and hearing) 
for the purpose of evaluating consumer products based on certain evaluation criteria. Using a sensory evaluation method, 3D virtual try-on result can be accessed by designers through touch and observation based on their experience and professional knowledge. By utilizing a pre-defined pattern modification model, pattern can be modified automatically based on the evaluation results.

\section{EXPERIMENTAL WORK}

In this research, a 3D-to-2D design based personalized garment design process is proposed. Figure 1 presents the proposed design process. The proposed design process begins with a personalized garment block design from 3D-to-2D design method. Using the flattened garment block pattern, extension of the desired garment pattern can be realized considering the garment style and fabric property. Then, using a $3 \mathrm{D}$ virtual try-on procedure, a fast validation of the proposed pattern can be realized using virtual fabrics. Designers and consumers can be invited to participate in the evaluation section. His/her sensory evaluation result based on the pre-defined evaluation criteria will be input into a predefined knowledge based pattern modification rule base. Pattern modification plans can be generated automatically. Using this method, 2D technical space of pattern making can be easily controlled by 3D perception space using 3D virtual try-on. Also, new design rule will be generated as a new input into the proposed knowledge based pattern modification rule base in order to enhance the precision of the automatic pattern modification. As a knowledge-based learning system, the more designers and consumers involved in the decision making of the design process, higher satisfaction of the design solution can be ensured.

In order to realize the proposed design process, two experiments are proposed. In Experiment I, garment patters for ready-to-wear garment products are extended from a set of garment block pattern designed by a 3D-to-2D design method. Fabric properties are tested in order to simulate corresponding virtual fabric. Based on the extended patters and virtual fabric, a $3 \mathrm{D}$ virtual try-on is performed for further evaluation. In Experiment II, an automatic pattern modification rule base is defined. First, a set of evaluation criteria is defined, then, corresponding pattern modification rules are discussed by pattern designers using their professional design knowledge.

\section{Experiment I Production pattern design and 3D virtual try-on}

In this study, a personalized garment block for a physically disabled lady with scoliosis from our previous study is applied [1]. Using the proposed block patterns, the design case of a shirt can be obtained. The specifications design sheet in figure 2 describes the requirements for the design elements of the shirt designed by designers in this study.

Then, several extension and sizing procedure are performed in oder to obtian the desired garment style in figure 2. Professional knowledge of pattern designers isutilized to support this process. These operations are:

Step 1: Adding $1 \mathrm{~cm}$ to the side seam, center front and back lines for all patterns, creating the buttonholes.

Step 2: Drawing vertical lines from the lowest armhole points to create the new side seam lines, increasing the length of the new side seam lines by $24.5 \mathrm{~cm}$ from the waistlines and drawing new lines vertical to the side seam lines to be the new bottom lines.

Step 3: Symmetrizing the back waist dart with the same value in the opposite direction of the original dart, while the symmetrical line is the end of dart legs (The two lines that converge at a predetermined point on the pattern.).

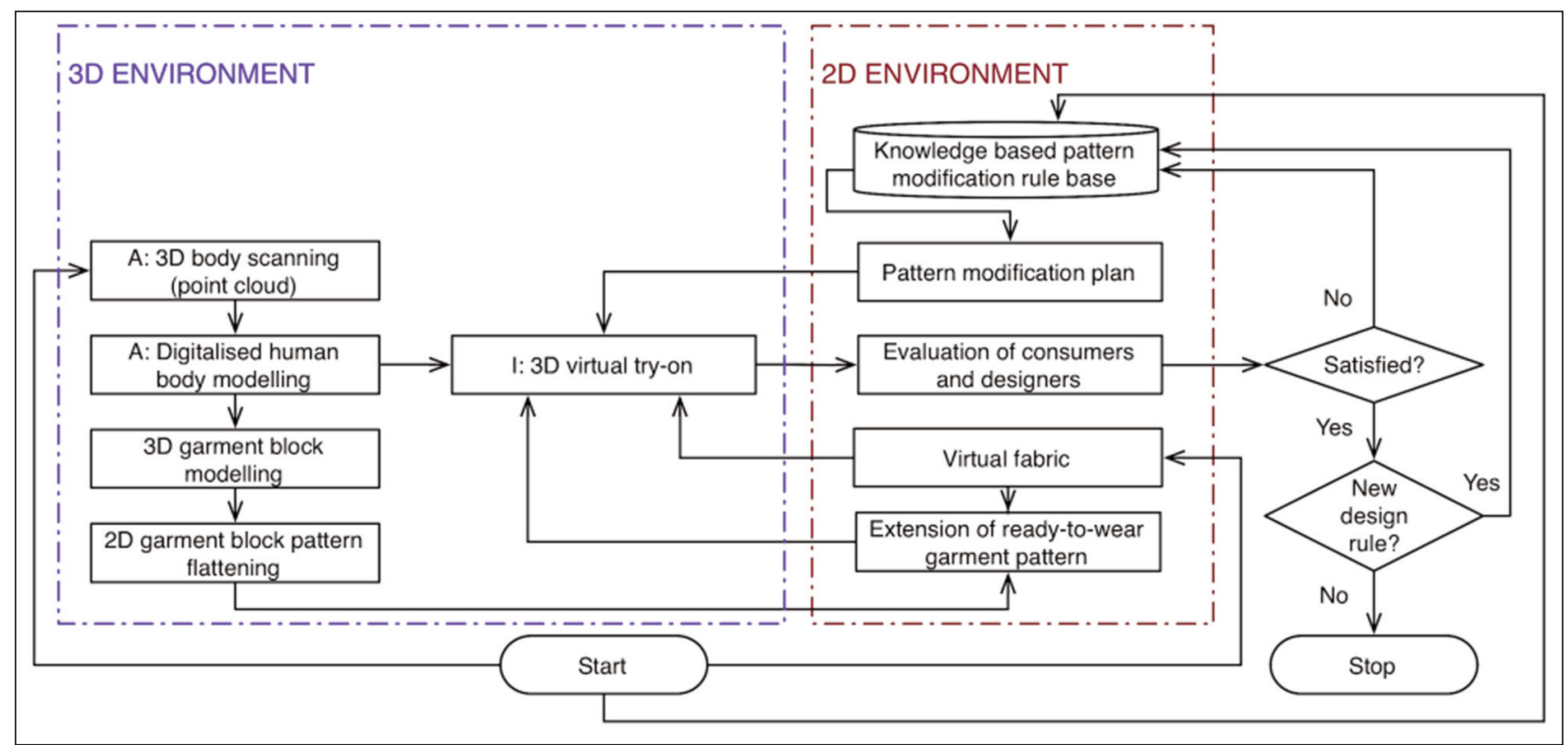

Fig. 1. Research framework and working process of the proposed design process 


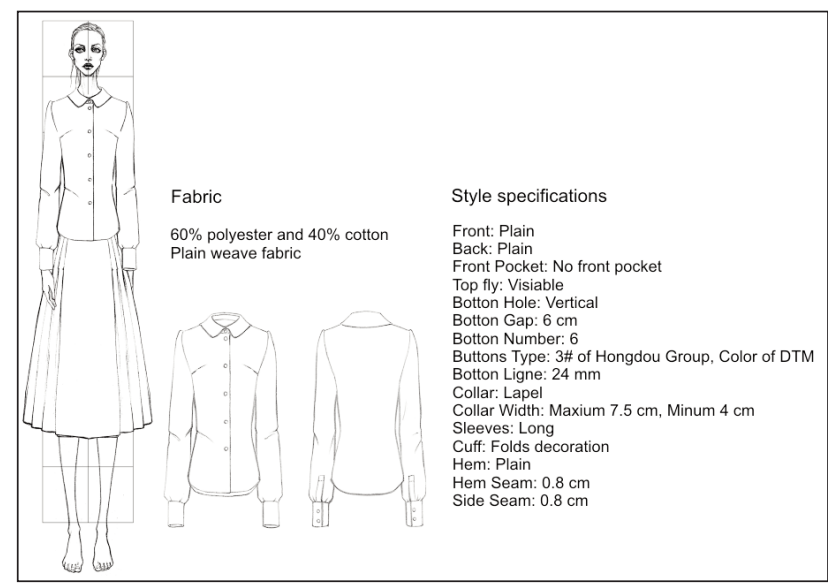

Fig. 2. The design specifications sheet of the shirt

Step 4: Drawing a straight line to be the grainline (the center of the sleeve from top of curved top of the sleeve top to wrist level) of the sleeve, measuring the front and back armholes of the previous patterns, recording the measurements on the patterns for future reference, adding the front and back armhole measurements together and divide the value into four to be the cap height of the sleeve (the distance from widest line of the sleeve to the top at the grainline).

Step 5: Determining the length of the cuff as $20 \mathrm{~cm}$ (add $4 \mathrm{~cm}$ to the girth of artifice as $16 \mathrm{~cm}$ ), the width of cuff as $5 \mathrm{~cm}$.

Step 6: Determining the height of the stand collar as $3 \mathrm{~cm}$ and the height of the top collar as $4 \mathrm{~cm}$.

By adding seam allowances and using Modaris software also with the virtual fabric, the production patterns of the designed shirt are finished, shown in figure 3 .

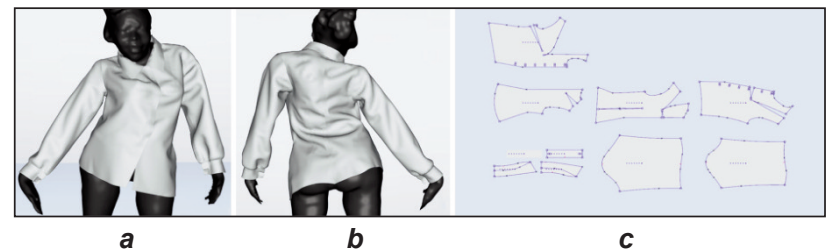

Fig. 3. Design result in both front and back views, and the corresponding garment patterns

\section{Experiment II Evaluation and adjustment of the 3D try-on perception}

In this study, a session of sensory evaluation is realized by a group of fashion designers and pattern makers in order to quantitatively characterize the 3D virtual try-on perception of the shirt designed using the customized block patterns [7-8]. Then, the adjustment of the shirt patterns can be realized in the 2D technical space according to the sensory evaluation results on the performance of the finished shirt in the 3D virtual try-on space. Evidently, the key issue of this adjustment is to set up a model characterizing the relationship between the technical space and 3D virtual product perceptual space. This model will permit to generate the appropriate technical parameters of the garment according to the desired values of

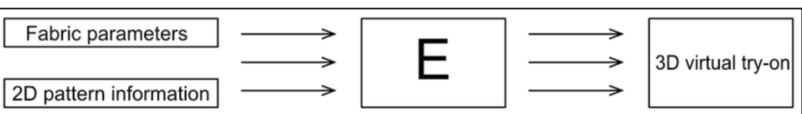

Fig. 4. Model characterizing the relation between technical parameters and perception on 3D virtual garment try-on

sensory evaluation on the effects of 3D virtual garment try-on (figure 4).

In this study, the aim of identifying the shirt fit in 3D virtual try-on evaluation is to generate normalized sensory descriptors, which constitute the common communication language between fashion designers, pattern makers and garment consumers [9-11]. Five experienced fashion designers are involved in the evaluation. The parameters of the fabric chosen by the designers as described in the design specifications sheet as well as the finished production patterns constitute the inputs to the Modaris software for realizing 3D virtual try-on. The style and design elements in the design specifications sheet can generate a common idea of the designers for the evaluation. In this context, the sensory evaluation results on the fit of the designed shirt, given by different designers, can be very close to each other. The sensory evaluation procedure used in our study is described as follows.

Each trained designer generates an exhaustive list of categories describing the shirt fit performance according to his/her professional knowledge. The three most relevant categories describing the key positions of the shirt have been selected: "Overall image", "fit in width" and "fit in details". Then, a list of descriptors describing the shirt fit in different categories is generated by the designers using their garment design knowledge and pattern design knowledge.

After that, there is a section reducing redundant descriptors and those irrelevant to the fit of a shirt, by performing a "round table" discussion inside the panellists. This step leads to the generation of 8 normalized descriptors describing the apparel fit performance (table 1). For each descriptor, a scale of five evaluation scores, ranging from -2 to 2 , is also

Table 1
SENSORY DESCRIPTORS DESCRIBING THE APPAREL FIT PERFORMANCE

\begin{tabular}{|l|l|}
\hline Categories & Apparel fit performance descriptor \\
\hline \multirow{2}{*}{$D_{A}:$ Overall image } & $D_{A 1}$ Overall fit \\
\cline { 2 - 2 } & $D_{A 2}$ Length \\
\hline \multirow{4}{*}{$D_{B}:$ Fit in width } & $D_{B 1}$ Waist fit \\
\cline { 2 - 2 } & $D_{B 2}$ Breast fit \\
\cline { 2 - 2 } & $D_{B 3}$ Hem fit \\
\hline \multirow{4}{*}{$D_{C}:$ Fit in details } & $D_{C 1}$ Shoulder fit \\
\cline { 2 - 2 } & $D_{C 2}$ Neck fit \\
\cline { 2 - 2 } & $D_{C 3}$ Arm hole fit \\
\hline
\end{tabular}


EVALUATION SCORES AND THE CORRESPONDING SEMANTICS

\begin{tabular}{|c|c|c|c|c|c|}
\hline Scores & $-\mathbf{2}$ & $-\mathbf{1}$ & $\mathbf{0}$ & $\mathbf{1}$ & $\mathbf{2}$ \\
\hline Semantics & Very tight/small & A little tight/small & Perfect & A little loose/big & Very loose/big \\
\hline
\end{tabular}

obtained. "-" means that the garment is tight or small related to the body shape while "+" means in the opposite direction (big or loose). 0 is a perfect fit on the wearer. Each score of the scale is defined semantically in table 2 .

By repeating the evaluation two times and taking the average of the evaluation scores for each sensory descriptor, we finally obtain a matrix composed of all evaluation scores.

The adjustment of the current patterns will be realized using a rule-based model characterizing the relation between evaluations values on the shirt fit (perceptual space) and modifications of garment patterns (technical space). It has been established by exploiting the common professional knowledge of pattern makers through a round table discussion

Table 3

\begin{tabular}{|c|c|c|}
\hline \multicolumn{3}{|c|}{$\begin{array}{l}\text { MODIFICATION RULES BASED ON EVALUATION } \\
\text { RESULT }\end{array}$} \\
\hline $\begin{array}{c}\text { Sensory descriptors } \\
\text { on garment fit }\end{array}$ & $\begin{array}{l}\text { Rule } \\
\text { code }\end{array}$ & Modification rules \\
\hline \multirow{3}{*}{$D_{A 1}$ Overall fit } & $\mathrm{D}_{\mathrm{A} 1 \mathrm{a}}$ & $\begin{array}{l}\text { Change the length } \\
\text { of waistline }\end{array}$ \\
\hline & $\mathrm{D}_{\mathrm{A} 1 \mathrm{~b}}$ & $\begin{array}{l}\text { Change the length } \\
\text { of breast line }\end{array}$ \\
\hline & $\mathrm{D}_{\mathrm{A} 1 \mathrm{c}}$ & $\begin{array}{l}\text { Change the length } \\
\text { of shoulder line }\end{array}$ \\
\hline$D_{A 2}$ Length & $\mathrm{D}_{\mathrm{A} 2 \mathrm{a}}$ & $\begin{array}{l}\text { Change the length of } \\
\text { the garment }\end{array}$ \\
\hline \multirow{2}{*}{$\mathrm{D}_{\mathrm{B} 1}$ Waist fit } & $\mathrm{D}_{\mathrm{B} 1 \mathrm{a}}$ & $\begin{array}{l}\text { Change the cut } \\
\text { of side seam }\end{array}$ \\
\hline & $\mathrm{D}_{\mathrm{B} 1 \mathrm{~b}}$ & $\begin{array}{l}\text { Change the value } \\
\text { of waist dart }\end{array}$ \\
\hline \multirow{2}{*}{$D_{B 2}$ Breast fit } & $\mathrm{D}_{\mathrm{B} 2 \mathrm{a}}$ & $\begin{array}{l}\text { Change the cut } \\
\text { of side seam }\end{array}$ \\
\hline & $\mathrm{D}_{\mathrm{B} 2 \mathrm{~b}}$ & $\begin{array}{l}\text { Change the value } \\
\text { of breast dart }\end{array}$ \\
\hline $\mathrm{D}_{\mathrm{B} 3}$ Hem fit & $\mathrm{D}_{\mathrm{B} 3 \mathrm{a}}$ & $\begin{array}{l}\text { Change the cut } \\
\text { of side seam }\end{array}$ \\
\hline \multirow{3}{*}{$\mathrm{D}_{\mathrm{C} 1}$ Shoulder } & $\mathrm{D}_{\mathrm{C} 1 \mathrm{a}}$ & $\begin{array}{l}\text { Change the slope } \\
\text { of shoulder line }\end{array}$ \\
\hline & $\mathrm{D}_{\mathrm{C} 1 \mathrm{~b}}$ & $\begin{array}{l}\text { Change the length } \\
\text { of shoulder line }\end{array}$ \\
\hline & $\mathrm{D}_{\mathrm{C} 1 \mathrm{c}}$ & $\begin{array}{l}\text { Change the width } \\
\text { of neckline }\end{array}$ \\
\hline \multirow{2}{*}{$\mathrm{D}_{\mathrm{C} 2} \mathrm{Neck}$} & $\mathrm{D}_{\mathrm{C} 2 \mathrm{a}}$ & $\begin{array}{l}\text { Change the width } \\
\text { of neckline }\end{array}$ \\
\hline & $\mathrm{D}_{\mathrm{C} 2 \mathrm{~b}}$ & $\begin{array}{l}\text { Change the depth } \\
\text { of neckline }\end{array}$ \\
\hline \multirow{2}{*}{$\mathrm{D}_{\mathrm{C} 3}$ Armhole } & $\mathrm{D}_{\mathrm{C} 3 \mathrm{a}}$ & $\begin{array}{l}\text { Change the position } \\
\text { of sleeve top }\end{array}$ \\
\hline & $D_{C 3 b}$ & $\begin{array}{l}\text { Change the curvature } \\
\text { of the armhole }\end{array}$ \\
\hline
\end{tabular}

between these panellists. Five experienced pattern makers are involved in the production process. There are two steps for modelling the relationship:

Step 1: Identification of the shirt modification rules These rules will enable to determine the key points or key lengths of the shirt production patterns corresponding to each sensory descriptor in order to make the final shirt very close to the target wearing effect wished by the designers. The final modification rules provided by the pattern makers are given in table 3 . Normally, for each sensory descriptor, there are several alternative modification rules. However, in practice, only one rule is applied during the adjustment. One example is given below.

If we wish to modify "overall fit" $\left(D_{A 1}\right)$, then we can change the length of either waistline $\left(D_{A 1 a}\right)$, or breast line $\left(D_{A 1 b}\right)$ or shoulder line $\left(D_{A 1 c}\right)$.

Step 2: Identification of the new values of change for garment patterns

For each modification rule, the change of the identified key point or key length is determined according to the evaluation score of the corresponding sensory descriptor. The whole values of change of patterns related to all the modification rules, provided by the designers, are shown in table 4. For example, when applying the modification rule $\mathrm{D}_{\mathrm{A} 1 \mathrm{a}}$ related to the

Table 4

VALUES OF CHANGE FOR SHIRT PRODUCTION PATTERNS

\begin{tabular}{|c|c|c|c|c|c|}
\hline $\begin{array}{c}\text { Evaluation. } \\
\text { Scores }\end{array}$ & -2 & -1 & 0 & 1 & 2 \\
\hline $\mathrm{D}_{\mathrm{A} 1 \mathrm{a}}$ & $+8 \mathrm{~cm}$ & $+4 \mathrm{~cm}$ & 0 & $-4 \mathrm{~cm}$ & $-8 \mathrm{~cm}$ \\
\hline $\mathrm{D}_{\mathrm{A} 1 \mathrm{~b}}$ & $+8 \mathrm{~cm}$ & $+4 \mathrm{~cm}$ & 0 & $-4 \mathrm{~cm}$ & $-8 \mathrm{~cm}$ \\
\hline $\mathrm{D}_{\mathrm{A} 1 \mathrm{c}}$ & $+4 \mathrm{~cm}$ & $+2 \mathrm{~cm}$ & 0 & $-2 \mathrm{~cm}$ & $-4 \mathrm{~cm}$ \\
\hline $\mathrm{D}_{\mathrm{A} 2 \mathrm{a}}$ & $+4 \mathrm{~cm}$ & $+2 \mathrm{~cm}$ & 0 & $-2 \mathrm{~cm}$ & $-4 \mathrm{~cm}$ \\
\hline $\mathrm{D}_{\mathrm{B} 1 \mathrm{a}}$ & $+3 \mathrm{~cm}$ & $+1 \mathrm{~cm}$ & 0 & $-1 \mathrm{~cm}$ & $-3 \mathrm{~cm}$ \\
\hline $\mathrm{D}_{\mathrm{B} 1 \mathrm{~b}}$ & $+2 \mathrm{~cm}$ & $+1 \mathrm{~cm}$ & 0 & $-1 \mathrm{~cm}$ & $-2 \mathrm{~cm}$ \\
\hline $\mathrm{D}_{\mathrm{B} 2 \mathrm{a}}$ & $+3 \mathrm{~cm}$ & $+1 \mathrm{~cm}$ & 0 & $-1 \mathrm{~cm}$ & $-3 \mathrm{~cm}$ \\
\hline $\mathrm{D}_{\mathrm{B} 2 \mathrm{~b}}$ & $+2 \mathrm{~cm}$ & $+1 \mathrm{~cm}$ & 0 & $-1 \mathrm{~cm}$ & $-2 \mathrm{~cm}$ \\
\hline $\mathrm{D}_{\mathrm{B} 3 \mathrm{a}}$ & $+3 \mathrm{~cm}$ & $+1 \mathrm{~cm}$ & 0 & $-1 \mathrm{~cm}$ & $-3 \mathrm{~cm}$ \\
\hline $\mathrm{D}_{\mathrm{C} 1 \mathrm{a}}$ & $+4^{\circ}$ & $+2^{\circ}$ & 0 & $-2^{\circ}$ & $-4^{\circ}$ \\
\hline $\mathrm{D}_{\mathrm{C} 1 \mathrm{~b}}$ & $+3 \mathrm{~cm}$ & $+1 \mathrm{~cm}$ & 0 & $-1 \mathrm{~cm}$ & $-3 \mathrm{~cm}$ \\
\hline $\mathrm{D}_{\mathrm{C} 1 \mathrm{c}}$ & $+3 \mathrm{~cm}$ & $+1 \mathrm{~cm}$ & 0 & $-1 \mathrm{~cm}$ & $-3 \mathrm{~cm}$ \\
\hline $\mathrm{D}_{\mathrm{C} 2 \mathrm{a}}$ & $+3 \mathrm{~cm}$ & $+1 \mathrm{~cm}$ & 0 & $-1 \mathrm{~cm}$ & $-3 \mathrm{~cm}$ \\
\hline $\mathrm{D}_{\mathrm{C} 2 \mathrm{~b}}$ & $+3 \mathrm{~cm}$ & $+1 \mathrm{~cm}$ & 0 & $-1 \mathrm{~cm}$ & $-3 \mathrm{~cm}$ \\
\hline $\mathrm{D}_{\mathrm{C} 3 \mathrm{a}}$ & $+2 \mathrm{~cm}$ & $+1 \mathrm{~cm}$ & 0 & $-1 \mathrm{~cm}$ & $-2 \mathrm{~cm}$ \\
\hline $\mathrm{D}_{\mathrm{C} 3 \mathrm{~b}}$ & $+2 \mathrm{~cm}$ & $+1 \mathrm{~cm}$ & 0 & $-1 \mathrm{~cm}$ & $-2 \mathrm{~cm}$ \\
\hline & & & & \\
\hline
\end{tabular}




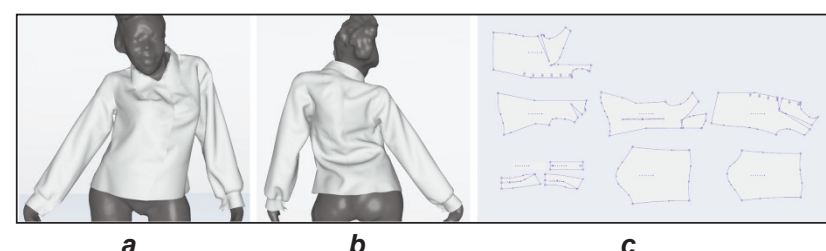

Fig. 5. Design result after modification in both front and back views, and the corresponding garment patterns

"overall fit", if the evaluation score is -1 (a little tight), then $4 \mathrm{~cm}$ will be added to the width of waistline in horizontal direction.

In practice, one modification rule and its corresponding pattern changing value can be arbitrarily selected and its try-on result can be quantitatively characterized using the sensory evaluation. If the adjustment result is not satisfying, another rule of the same sensory descriptor will be selected in order to generate a new try-on result. This procedure can be carried out repeatedly until finding the most relevant adjustment plan.

By using the previous two steps, we set up the relationship between 3D virtual shirt try-on results and 2D pattern parameters (key points and key lengths). This rule-based model permits to reach a desired perception of shirt fit by adjusting the 2D pattern parameters. In this study, the procedure of Design - Display - Evaluation - Adjustment with the model can be performed repeatedly until a satisfying design solution is obtained, as shown in figure 5. (Chen, Tao, Zeng, Koehl, \& Boulenguez-Phippen, 2015) (Chen et al. 2015) (Chen et al. 2015) [4] (Chen, Tao, Zeng, Koehl, \& Boulenguez-Phippen, 2015) (Chen, Tao, Zeng, Koehl, \& Boulenguez-Phippen, 2015) (Chen, Tao, Zeng, Koehl, \& Boulenguez-Phippen, 2015) (Chen, Tao, Zeng, Koehl, \& Boulenguez-Phippen, 2015) (Chen, Tao, Zeng, Koehl, \& Boulenguez-Phippen, 2015) $D_{A 2}$ Length, $D_{B 1}$ Waist fit, $D_{B 2}$ Breast fit, $D_{B 3}$ Hem fit, $D_{C 1}$ Shoulder fit and $D_{C 2}$ Neck fit of the initial pattern is modified using the rule based model based on the perception of the involved designers.

To validate the design result, following the design specifications sheet, the garment is produced following the garment patterns after modification. To evaluate the real shirt produced using the pattern modified as the evaluation results before, a fitting procedure is proposed. The fitting result is shown in figure 6 . As for the customer, the look and comfort of the shirt are perceived as fine during the fitting.

In order to validate the proposed design process, another group of designers are invited to compare the initial garment virtual try-on result and the final modified garment virtual try-on result using the evaluation criteria presented in table 1 .

First, there is a training section about the purposed of the evaluation. Then both the initial garment virtual try-on result and the final modified garment virtual tryon are presented to the invited designer group. The invited designers are free to operate the computer to observe the virtual try-on results. Each of the invited

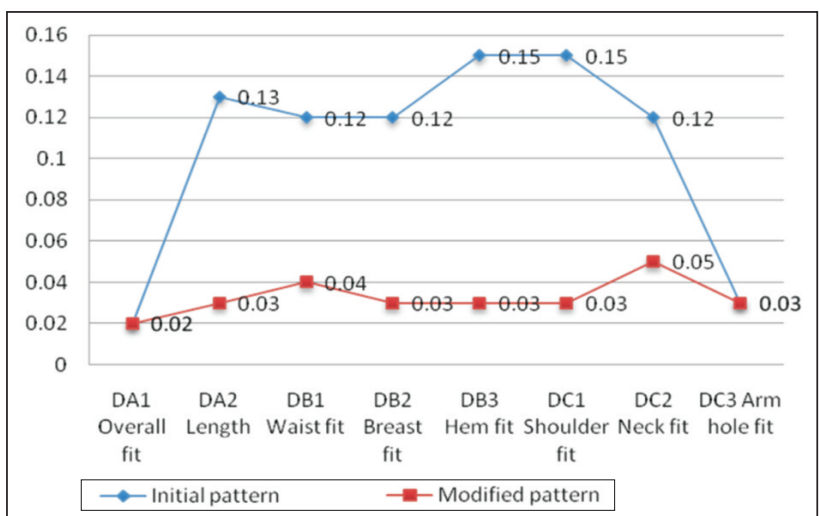

Fig. 6. Distances of aggregated evaluation results of all evaluation criteria to the degeree of "Perfect $(1.5,2,2.5)$ "

designers is assigned to finish the evaluation independently without any discussion with other designers.

\section{RESULTS AND DISCUSSION}

In order to quantify the evaluation degrees, a set of fuzzy numbers is assigned to each of the linguistic term. The involved evaluationlinguistic term and their corresponding fuzzy numbers are described in table 5 .

Table 5

\begin{tabular}{|c|c|}
$\begin{array}{c}\text { LiNGUISTIC RATING SCALE AND CORRESPONDING } \\
\text { FUZZY NUMBERS }\end{array}$ \\
\hline Linguistic values & TFNs \\
\hline Very loose/big & $(2.5,3,3.5)$ \\
\hline A little loose/big & $(2,2.5,3)$ \\
\hline Perfect & $(1.5,2,2.5)$ \\
\hline A little tight/small & $(1,1.5,2)$ \\
\hline Very tight/small & $(0.5,1,1.5)$ \\
\hline
\end{tabular}

Then, using the following equation to aggregate the evaluation result of all the involved designers:

$$
a_{i j}=\left(\frac{1}{m} \sum_{j=1}^{l} a_{i j h} t_{1}, \frac{1}{m} \sum_{j=1}^{1} a_{i j h} t_{2}, \frac{1}{m} \sum_{j=1}^{l} a_{i j h} t_{3}\right)
$$

Where $t_{1}, t_{2}, t_{3}$ correspond to the value of TFNs, and their values are taken according to table 3 [12-14].

Then, Euclidean distance of between all the aggregated evaluation results to the semantic degree "Perfect $(1.5,2,2.5)$ is calculated in order to measure the satisfaction of invited designers of both initial garment virtual try-on result and finial modified virtual try-on result, as presented in figure 6 . These distances indicate the satisfaction degree of each part of the virtual try-on result in terms of different evaluation criteria. Shorter distance indicates higher membership degree.

$D_{A 2}$ Length, $D_{B 1}$ Waist fit, $D_{B 2}$ Breast fit, $D_{B 3}$ Hem fit, $D_{C 1}$ Shoulder fit and $D_{C 2}$ Neck fit are less satisfactory compared to the initial pattern. Some modification should be performed on these parts, matching the designers' idea referring to Experiment II. 
Generally, the modified pattern is more "perfect" compared with the initial pattern, which indicates that the proposed Design - Display - Evaluation Adjustments procedure is able to help to reach a desired perception of shirt fit by adjusting the 2D pattern parameters using the proposed rule-based model. 2D pattern parameters (key points and key lengths) can be adjusted by the evaluation result of the 3D virtual try-on results.

\section{CONCLUSIONS}

In this paper, to validate the applicability of 3D-to-2D garment design method, we introduced an application case of designing a personalized garment for physically disabled people with scoliosis (PDPS) using a set of garment block pattern designed by a 3D-to-2D garment design method. The proposed design process begins with a personalized garment block design from 3D-to-2D design method. Desired garment patterns are realized by the extension of the previous garment block pattern considering both desired garment style and fabric properties. After that, using the proposed pattern and virtual fabric, a $3 \mathrm{D}$ virtual try-on can be realized and ensures a fast validation of the proposed pattern. Designers and consumers are able to participate in the evaluation section. Also, we defined a rule-based pattern modification model to validate the designer design idea. Based on sensory evaluation results, pattern modification plan can be generated. Though a validation experiment, it can be proved that, as knowledge based learning process, the proposed design process is able to ensure a high level of design satisfaction of consumers.

\section{BIBLIOGRAPHY}

[1] Yan Hong, Xianyi Zeng, Pascal Bruniaux, Kaixuan Liu. Interactive virtual try-on based three-dimensional garment block design for disabled people of scoliosis type, In: Textile Research Journal. 2016, vol. 72, issue 2, pp. $156-163$.

[2] Cupar, A., Development of classification methodology of perceptional surfaces in product design, In: Doctoral Dissertation, University of Maribor, Faculty of Mechanical Engineering, 2015.

[3] Kaixuan Liu, Edwin Kamalha, Jianping Wang, Tarun-Kumar Agrawal. Optimization design of cycling clothes' patterns based on digital clothing pressures, In: Fibers and Polymers. 2016, vol.17, issue 9, pp. 1522-1529.

[4] Yan Hong, Min Yang, Yan Chen. Development of clothing micro climate monitoring system for human physiological indexes, In: Journal of Textile Research. 2013, vol. 34, issue 1, pp. 96-100.

[5] Niculescu, C., Mielicka, E., Salistean, A., Napieralska, L., Popescu, G., \&Mocenco, A. Web portal for customized production of clothing for overweight and elderly people, In: IndustriaTextila, 2016, vol. 67, issue 3, p. 194.

[6] Rudolf, A., Cupar, A., Kozar, T., Stjepanović, Z. Study regarding the virtual prototyping of garments for paraplegics. In: Fibers and polymers, ISSN 1229-9197, May 2015, vol. 16, no. 5, pp. 1177-1192.

[7] Park C.K., Kang T.J. Objective evaluation of seam pucker using artificial intelligence Part II: Method of evaluating seam pucker, In: Textile Research Journal, 1999, vol. 69(11), pp. 835-845.

[8] Lau T.W., Hui P.C.L., Ng F.S.F., Chan K.C.C. A new fuzzy approach to improve fashion product development, In: Computers in Industry, 2006, vol. 57, pp. 82-92.

[9] Ries, al., Trout, J. (1985), Positioning: The battle of the mind, McGraw-Hill Companies.

[10] Olson, J.C., Jacoby, J. (1972), Cue Utilization in the quality perception process, In: Venkatesan, M. (Ed.): Proceedings of the Third Annual Conference of the Association for Consumer Research, Association for Consumer Research, Chicago, IL, pp. 167-179.

[11] Solomon, M.R. (2009), Consumer behaviour: buying, having, and being, Prentice Hall.

[12] Park S.W., Hwang Y.G., Kang B.C., Yeo S.W. Applying fuzzy logic and neural networks to total hand evaluation of knitted fabrics, In: Textile Research Journal, 2000, vol. 70(8), pp. 675-681.

[13] Takagi T., Sugeno M. Fuzzy identification of systems and its application to modeling and control, In: IEEE Transactions on Systems, Man, and Cybernetics, 1985, vol. 15(1), pp. 116-132.

[14] Tahal, I., Abdin, Y., Ebeid, S. Prediction of draping behavior of woven fabrics over double-curvature moulds using finite element techniques, In: International Journal of Material and Mechanical Engineering, 2012, vol. 1, pp. 25-31.

\section{Authors:}

YAN HONG ${ }^{1,2,3}$, PASCAL BRUNIAUX², JUNJIE ZHANG ${ }^{4}$, KAIXUAN LIU ${ }^{4}$, MIN DONG ${ }^{4}$, YAN CHEN ${ }^{4}$

${ }^{1}$ College of Textile and Clothing Engineering, Soochow University, Suzhou 215021, China

2 GEMTEX, ENSAIT, 2 allée Louise et Victor Champier, 59056 Roubaix Cedex 1, France

${ }^{3}$ Technical University of lasi, Dimitrie Mangeron Bd., 53, lasi - 700050, Romania

${ }^{4}$ Department of Mathematics and Computer, Wuhan University of Textile, Wuhan 430070, China

\section{Corresponding author:}

YAN HONG

e-mail: yannichonghk@gmail.com 


\title{
Effect of paste properties as inkjet printing film and Mathematical Model to Follow the Kinetic of Wetting Phenomenon
}

\author{
DOI: $10.35530 / I T .069 .01 .1366$
}

AMAL CHEBIL

ZOUHAIER ROMDHANI

MUSTAPHA JENDOUBI

\section{REZUMAT - ABSTRACT}

Efectul proprietăților pastei ca film de imprimare cu jet de cerneală și modelul matematic pentru urmărirea fenomenului cinetic al umectării

Imprimarea cu jet de cerneală este un tip de imprimare fără impact, având capacitatea de a produce imagini color de înaltă calitate. Aplicarea acestei proceduri este foarte delicată în ceea ce privește compoziția pastei și condițiile operative. În primul rând, acest studiu investighează morfologiile de uscare pentru filmul de acoperire utilizat în acest domeniu. A fost studiat, de asemenea, efectul compușilor filmului care sunt utilizați pe scară largă ca acoperiri funcționale în textile. Condițiile de uscare și compușii sistemului, agent de îngroșare - uree, afectează în profunzime morfologia filmului de acoperire. Mai mult, comportamentele de umectare și de impregnare sunt direct legate de compușii sistemului studiați și de aplicațiile experimentului. În final, aceste rezultate obținute sunt confirmate de comportamentul la umectare al tricoturilor din poliamidă.

Cuvinte-cheie: imprimare cu jet de cerneală, agent de îngroșare, morfologie de uscare, umectare

Effect of paste properties as inkjet printing film and Mathematical Model to Follow the Kinetic of Wetting Phenomenon

Inkjet printing is a type of non-impact printing with the ability to produce high quality color images. The application of this procedure is very delicate in term of the paste composition and the operative conditions. In this field, firstly the present paper investigates the drying morphologies for the coating film. Then, the effect of film compounds which are widely as functional coatings in textile was studied. Results show that the drying condition and the system thickener - urea compounds affect deeply the film coating morphology. Furthermore, the wetting and the impregnation behaviors are directly related to the studied system compounds and the experiment applications. Finally, these obtained results are confirmed by the wetting behavior on the knitted polyamide fabrics.

Keywords: inkjet printing, thickener, drying morphology, wetting

\section{INTRODUCTION}

Textile printing markets are changing rapidly due to demands imposed by globalisation, mass customisation, quick response, cost effectiveness and ecology. These factors have significantly influenced the global textile printing which lead to the evolution of digital printing [1-3]. Digital ink-jet printing is a non-contact printing technology. The ink droplets are produced and deposited on substrates materials in response to an electronic signal [4]. The ink-jet printing of textiles offers many potential benefits over conventional screen printing methods [5-6]. It is recognized as the best available simple technique and environmentally clean technology. The ink-jet printing technology don't need the preparation of printing screens. Therefore, the digital design can directly transferred onto the textile surface with the computer software and ink-jet printers. Then, less dye, energy and water are consumed in ink-jet than in screen printing [7-9]. In recent years, ink-jet printing has been increasingly popular due to its simple operation procedures, such as paste pre-treatment, ejected ink adjustment, steaming and washing, which facilitate control of printing quality [10].
First the fabric needs to be pre-treated prior to printing where it has to be padded with a pre-treatment paste [11-15]. Then, the print is then normally steamed to fix the dye onto the cotton fabric and then washed thoroughly to remove any unreacted dye, chemicals and thickener. The paste is usually prepared with either sodium alginate or chitosan [12, 14-15] in the presence of sodium bicarbonate and urea. These compounds print paste and process conditions have important effect on the final color design. Therefore, different factors affect the spreading, diffusion and evaporation phenomena of the ink droplet which control the design contour and the ink fixation. Several studies show the effect of the type of used thickener film in ink-jet printing process and it is demonstrated that the rheological properties of the printing pastes are principally determined by thickeners [16-18]. Therefore, the print paste rheology is a key word for printing quality, so it affects color properties. Indeed, the drying of coating substance on materials has important effect on various industrial applications such as inkjet printing [19-20]. In fact, Kagami [21-24] shows that molecules distribution of the paste solution on the substrate after drying is 
described by a power relation between the vaporization rate, the diffusion coefficient of the solvent and the concentration of the solution. Then, the morphological structures resulting from the drying conditions of 'thickener - urea' are of crucial importance as regards the wetting phenomenon. Finally, different recipe compounds and their percentage have significant effect on the ink droplet spreading. On the other hand, the steaming time after ink-jet printing, are the main factors affecting the final color yield.

In the same case of factors affecting the ink-jet printing result, the textile properties affect deeply the liquid transport in textile fabric [25]. Moreover, Fan and Kim [26-27] investigated the effect of weave of fabrics on the ink jet printing quality and they showed that the plain weave fabrics have the highest effect than the knitted one. Then, these authors have studied the effect of different treatments and used recipes on the fabric. They demonstrated that the effect of fabric structure on printing quality disappears when pretreatments are included. In the same line, Park and co-workers [28] conducted a similar study. They assessed mainly the effect of fabric structure (weave), pretreatments and ink type. They confirmed the significance of fabric structure, yarn size and hydrophilic/hydrophobic nature of the fabric.

The present study aims to fulfill and put the accent on important factors compounds and their percentages of the paste recipe on the wetting phenomenon on inkjet printing film. Then, we are interested on the drying morphology of coating paste. Finally, mathematical modeling was put in to estimate the wetting phenomenon.

\section{EXPERIMENTAL SECTION}

\section{Finishing treatment}

Before experiment setting, glass substrates $(2,5 \times 2,5$ $\mathrm{cm}^{2}$ ) were used to deposit the coating paste film in order to study its morphology and its wetting behavior. These glass plates have been cleaned previously to the ultrasonic sounds during 30 seconds in the ethanol, then rinsed with the same solvent and dried to nitrogen. Then the surface is treated and activated in an oxidizing solution "Piranha" in $50{ }^{\circ} \mathrm{C}$ during 30 min (mixture of 3 vol. of $30 \% \mathrm{H}_{2} \mathrm{O}_{2}$ and 7 vol. $\mathrm{H}_{2} \mathrm{SO}_{4}$ ), to produce highly hydrophilic surfaces. This treatment is finished by rinsing with deionised and twice distilled and then dried under flux of nitrogen. The acid coating solution was supplied from an industrial society specialized in ink-jet printing (Textile Industrial Company (ITS), Monastir - Tunisia). The characteristics of the acid coating solution were given in table 1.

The coating paste films were prepared by spin coating onto clean glass plates $\left(2.5 \times 2.5 \mathrm{~cm}^{2}\right)$ for $30 \mathrm{sec}-$ ond at an angular velocity $2000 \mathrm{rpm}$. The paste solution was prepared according to the optimal printing recipe. In order to study the effect of important compounds of the recipe, we are interested of the thickeners and the urea. Three quantities of the thickeners

\begin{tabular}{|l|l|}
\hline \multicolumn{1}{|c|}{ Compounds } & \multicolumn{1}{c|}{ Concle 1} \\
\hline Minerprimer P-INK $(\mathrm{g} / \mathrm{L})$ & 100,200 and 300 \\
\hline Urea $(\mathrm{g} / \mathrm{L})$ & 50,100 and 150 \\
\hline Setaprint NDG $(\mathrm{g} / \mathrm{L})$ & 20 \\
\hline Bicarbonate $(\mathrm{g} / \mathrm{L})$ & 45 \\
\hline
\end{tabular}

product were used (100 g/L, $200 \mathrm{~g} / \mathrm{L}$ and $300 \mathrm{~g} / \mathrm{L})$, then the effect of urea were quantified and three values were used (50 g/L, $100 \mathrm{~g} / \mathrm{L}$ and $150 \mathrm{~g} / \mathrm{L})$.

\section{Techniques of measure}

In order to study the morphology properties of different prepared coating film, thin acid coating films were observed with an optical microscope of which the fine morphological structures were obtained. For best resolution of structures, pictures were repeated 10 times. For the drying morphologies two temperatures were studied, the coating film or the coated fabric was dried at room temperature $\left(25^{\circ} \mathrm{C}\right)$ and oven conditions $\left(110^{\circ} \mathrm{C}\right)$ during 120 seconds. To quantify the wetting phenomenon, the ink droplet $(45 \mathrm{mN} / \mathrm{m})$ was used and the evolution of drop profile was captured with video-camera of GBX Digidrop with 25 captures per second. Every measure was repeated 3 times.

\section{Experimental design method}

The obtained results were analyzed using the software Minitab 15 and the main effects, interactions between factors, the regression model and response plot were determined. The general behavior of different phenomena as the spreading, the diffusion and the evaporation, can be represented by the regression model and the correlation between parameters. The choice of adequate equation which should be used is dependent of the $\mathrm{R}^{2}$-value of each model and the $p$-value tells us whether a variable has statistically significant.

Statistical approaches are the ideal means for optimization studies in industrial processes. The level and code of variables considered in this study are shown in table 2 . The concentration of the thickener, the concentration of urea and the time are selected as independent variables. The choice of these factors is approved by their important effect on the studied phenomenon.

Table 2

\begin{tabular}{|l|c|c|c|c|}
\hline \multicolumn{1}{|c|}{ Variables } & Symbols & \multicolumn{3}{c|}{ Levels } \\
\hline Concentration of thickener & CT (g/L) & 100 & 200 & 300 \\
\hline Concentration of urea & CU (g/L) & 50 & 100 & 150 \\
\hline Time & T (s) & $0,5,10,15,20$ \\
\hline
\end{tabular}

\section{RESULTS AND DISCUSSION}

\section{Effect of drying conditions}

In order to study the effect of the drying temperature on the paste coating film, two drying conditions were 


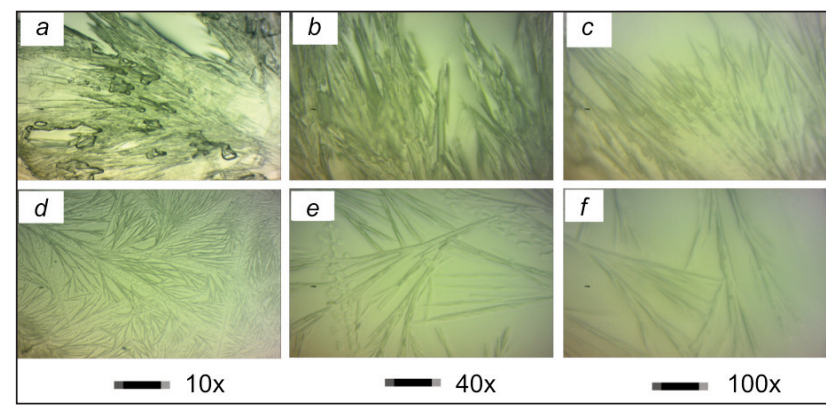

Fig. 1. Optical micrographs showing the representative morphologies resulting from the two extreme drying conditions; $a, b$ and $c$ ambient - dried $\left(22{ }^{\circ} \mathrm{C}, 30 \% \mathrm{RH}\right)$ and, $d$, $e$ and $f$ oven - dried $\left(22^{\circ} \mathrm{C}, 30 \% \mathrm{RH}\right)$

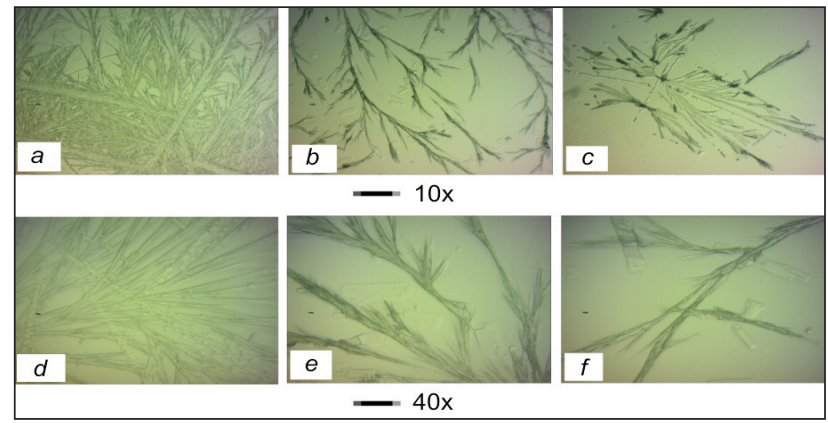

Fig. 2. Optical micrographs showing the representative morphologies of the paste recipe resulting from three living time in the oven room; $(a-d) 60$ seconds $(b-e)$ 120 seconds and $(c-f) 180$ seconds

used. The ambient drying conditions $\left(22^{\circ} \mathrm{C}, 30 \% \mathrm{RH}\right)$ and the oven drying one $\left(110^{\circ} \mathrm{C}, 2 \mathrm{~min}\right)$.

The ambient $\left(22^{\circ} \mathrm{C}, 30 \% \mathrm{RH}\right)$ and oven $\left(110^{\circ} \mathrm{C}, 2 \mathrm{~min}\right)$ drying morphologies of the coatings paste are shown in figure 1. The micrographs oven drying morphology show uniform and homogenous structure at this micrometer scale (figure $1, d$ ). But the one of the ambient drying conditions is characterized by the highly anisotropic and dense crystal, line domains composed needle - like fibrils (figure 1,a). Indeed, while increasing the temperature, the size of crystals decreases and the structure becomes more and finer and compact (figure 1,f). The coating layer becomes more uniform and homogeneous as shown in the optic microscopy. These needle-like structures (figure $1, a)$ are grown from the evaporating polar solvents. Then, this structure may be explained by the segregation of the urea phase and the residual components during the drying. Finally the morphological difference of the two drying conditions can be due to the extraction kinetics and the equilibrium residual water amount.

\section{Effect of the oven drying time}

In this paragraph the time of the oven drying conditions was analyzed. Three studied time (60 seconds, 120 seconds and 180 seconds) were used at the same oven drying temperature $110^{\circ} \mathrm{C}$.

The video-images in figure $3, a, b, c$ and $d$ show the top view of the wetting spot at first contact water drop-coating film and at the maximum spreading. The

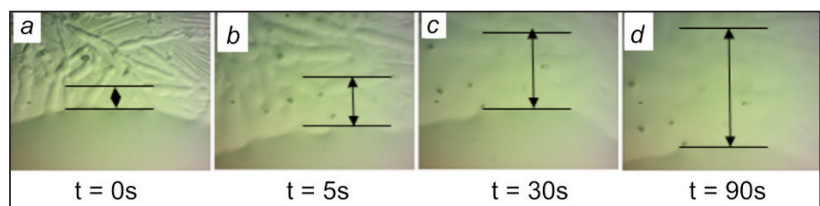

Fig. 3. Optical video-microscopy images showing the drop at different times on the thickener coating for the oven-drying conditions

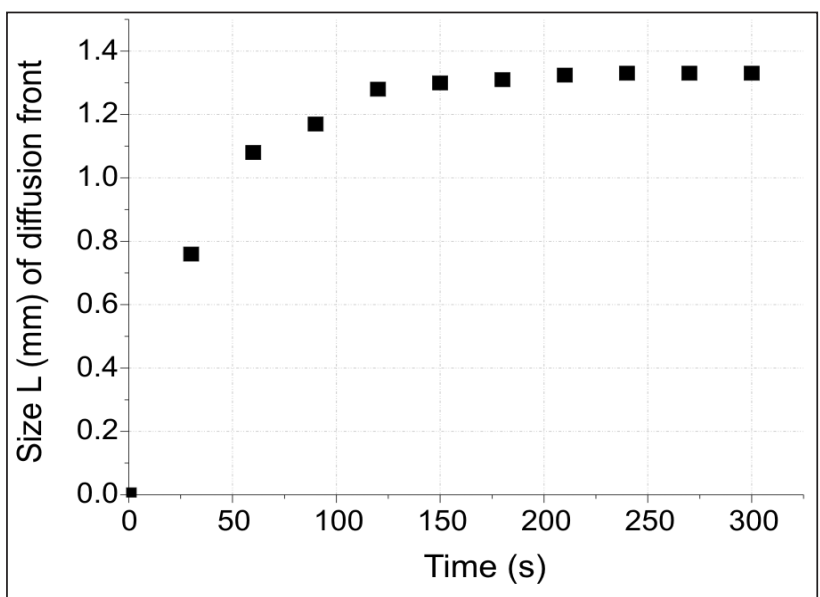

Fig. 4. Time growth of the diffusion front of the water drop on coating film at oven drying conditions

evolution of the drop profile on the oven coating film possesses axi-symmetry shape which indicates and confirms the morphological homogeneity of this coating film. This drop wetting behavior according to the drying morphology may affect the wetting phenomenon. This morphology can controls other than the drop shape, the wetting as the spreading and the diffusion of liquid into the coating film. In this case, we plotted the time growth of the diffusion front of the water drop on the oven drying coating film given by figure 4 . The drying morphology influences deeply the spreading and the diffusion of the water drop. Important spreading rate was observed for the first instants and the size $L_{e q}$ was obtained for two minutes and it's equal to $1,326 \mathrm{~mm}$. At longs time, after two minutes, this diffusion front is constant and the diffusion dominates the wetting phenomenon. The variation of the size $(L)$ of the diffusion front follows exponential distribution as given in the following equation:

$$
\left[L(t) / L_{e q}\right] \sim\left[1-\exp \left(-t / \tau_{e q}\right)\right]
$$

With $t$ is the time and $\tau_{e q}$ - the characteristic time constant of growth of the diffusion front. The diffusion front evolution show the conformity of the theory resulted which follow the classical Washburn-Rideal square-root dependence on time.

The drying conditions affects considerably the coating paste morphology and the especially the size of the diffusion front around the wetting spot as demonstrated above. Further experimental evidence towards these morphological effects are given in figure 5 , which represents the time variation of the drop profile on the glass plate, the ambient dried and oven dried 

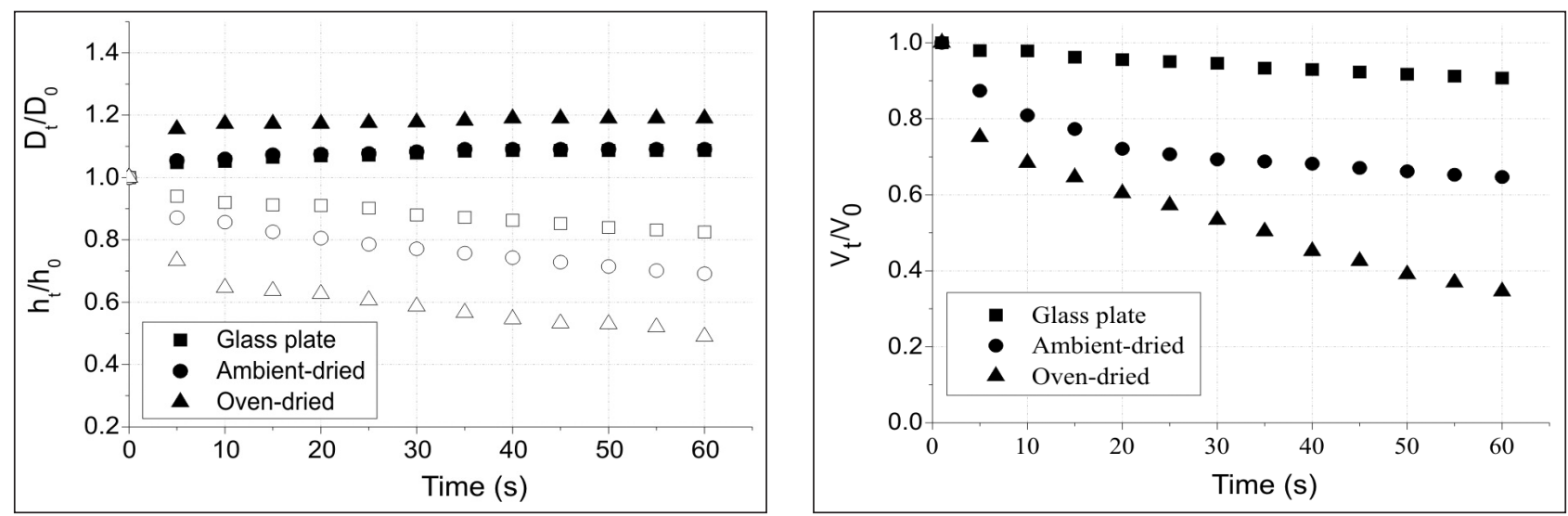

Fig. 5. Morphology-dependent wetting kinetics of the drying temperature of the coatings paste and the virgin glass plate as characterized by the time-evolution of the drop contact angle, diameter, height and the volume

coating film. From the comparison of wetting parameters (spreading, diffusion and evaporation) on used systems (drop - glass plate, drop - ambient dried film and drop - oven dried film) three phenomena were identified as the spreading, the diffusion (for the coating film) and evaporation that control the evolution of the drop profile. The profile of the drop evolves according to two distinct governments. The first is at short times until 30 seconds, which characterized by the coexistence of the spreading and evaporation. In the second left (long times) the stabilization phase was observed where the drop diameter reach its maximal spreading and stabilized. But the volume continues to decrease with slow slope. Therefore, the evaporation and the diffusion control the drop profile during this running.

Therefore, from this figure, the rate and extend of the spreading on the oven dried coating film was very larger than others used systems. But the spreading rate of the ambient dried conditions remains slightly higher than the glass plate. Thus, the thinning rate $\left(I \Delta h_{t} / \Delta t\right)$ of this wetting film is smaller than that measured on the glass plate and ambient-dried conditions. This is may be explained by the effect of the morphological structure of the coating film after drying conditions. The oven dried film possesses homogenous surface without irregularities which encourages the spreading phenomenon (axi-symmetry drop profile and the highest spreading rate) and the diffusion. The latter phenomenon can be explained that the oven-dried is susceptible to absorb more water quantities, so its dehydration level as its reabsorbing water propensity to reabsorb water is very important. Thus, this explanation can be confirmed by the important decrease of the volume for the oven dried coating film. Contrarily, the ambient dried film has the smaller thinning rate $\left(I \Delta \mathbf{h}_{\mathbf{t}} / \Delta \mathbf{t} \mathbf{l}\right)$ than the glass plate and more important compared to the oven dried film. Finally, the wetting phenomenon on the ambient dried conditions has the lower diffusion rate than the oven dried film.

\section{Effect of the paste constituent}

In this part, the effect of each constituent on the film morphology and on its wetting phenomenon was investigated. The thickener and the urea were studied. Three concentration of each component were used of the thickener and the urea respectively (100, 200 and $300 \mathrm{~g} / \mathrm{L}$ ) and (50, 100 and $150 \mathrm{~g} / \mathrm{L})$. The solutions of different composition have been smeared by 'spin coating' on glass plate and dried under oven drying condition to $110^{\circ} \mathrm{C}$ during 2 minutes, then captured with optic microscope. These drying morphologies of different studied films, as well as optic microscopy reveals it, are given in figure 6 and figure 8 . Their wetting behavior was illustrated in figure 7 and figure 9 .

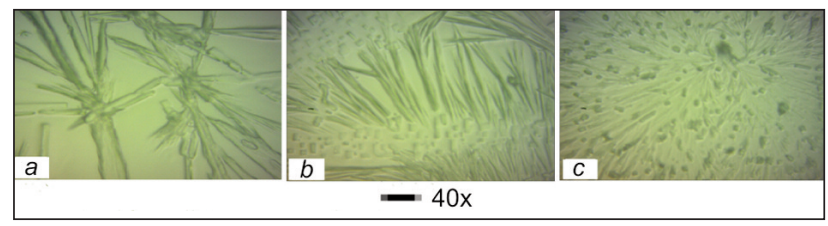

Fig. 6. Optical micrographs showing the representative morphologies resulting from three rate of thickener in the paste recipe; $a-100 \mathrm{~g} / \mathrm{L}, b-200 \mathrm{~g} / \mathrm{L}$ and

$$
c-300 \mathrm{~g} / \mathrm{L}
$$

For the coating film having the weakest concentration of the thickener possesses a structure with highly anisotropic and dense crystalline domains composed needle-like fibrils. The increasing of the concentration of thickener in the solution, the film structure stretches toward a more uniform surface. Therefore the gotten structure can be explained by two phenomena. On the one hand, the coating film structure having the weakest concentration is similar to the structure of sodium carbonate that possesses a one presenting important rate of crystallization. The size, the density and the distribution of crystals vary according to the kinetics of evaporation and nucleation-crystallization. On the other hand, this structure can be explained by a coupling or interaction between thickener-carbonate. While increasing the concentration of the thickener, we have a total dominance of the 

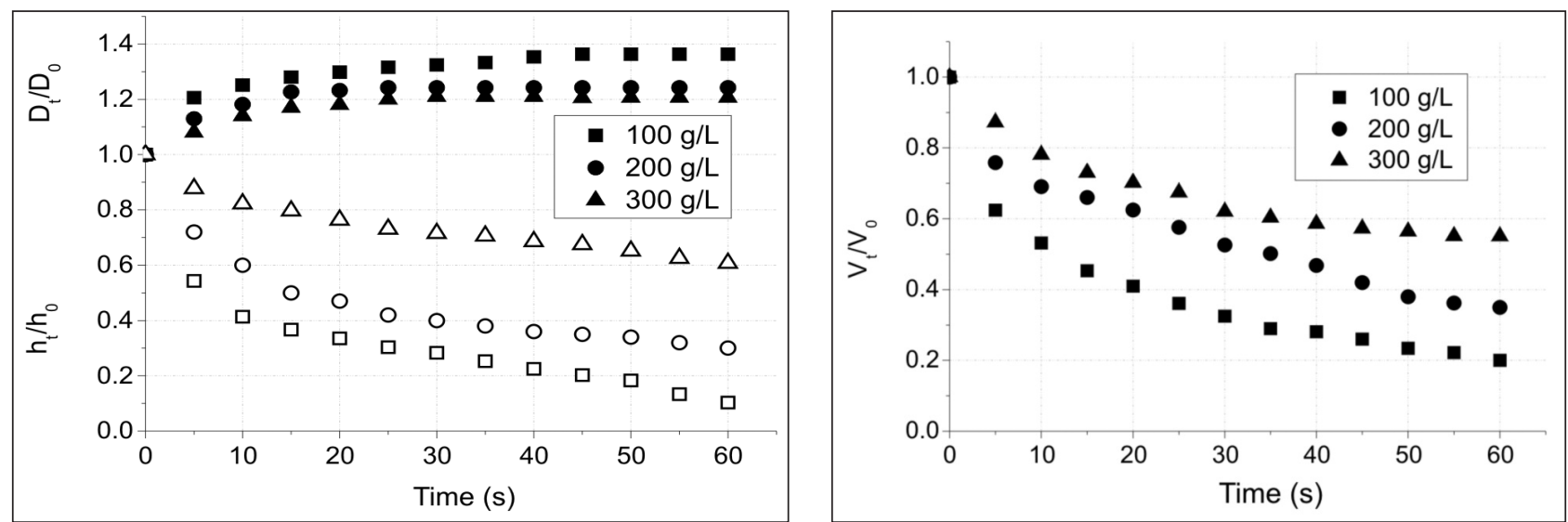

Fig. 7. Morphology-dependent wetting of the thickener coatings concentration as characterized by the time-evolution of the drop diameter, height and the volume adimensional

structure of the last constituent in relation to the one of the sodium carbonate.

The wetting kinetic of the adimensional drop height (ht/h0) and adimensional drop diameter (Dt/D0) according to different thickener concentration are plotted in figure 7 . The increasing of the thickeners concentration in the paste solution affects deeply the wetting phenomenon, especially the spreading, the diffusion and the evaporation phenomena. The wetting kinetic and the amplitude are very important for the low thickener concentration. The increase of the concentration of the thickener generates a slowing of the wetting phenomenon. Therefore important contact angle which leads to minimal spreading and diffusion for the most important thickener concentration. Then, the coating film having the important thickener concentration $(300 \mathrm{~g} / \mathrm{L})$ has the smaller thinning rate $\left(\mathbf{I} \Delta \mathbf{h}_{\mathbf{t}} / \Delta \mathrm{tl}\right)$ compared to the low one $(100 \mathrm{~g} / \mathrm{L})$. This observation was confirmed by the adimensional volume evolution which shows the important drop diffusion rate $\left(I \Delta h_{t} / \Delta t\right)$ for the coating film where we are the low thickener concentration.

Therefore, for the effect of the urea concentration, the formulation standard of the paste shows a structure presenting anisotropic surface and an elevated crystallization rate. On the other hand the increase of the

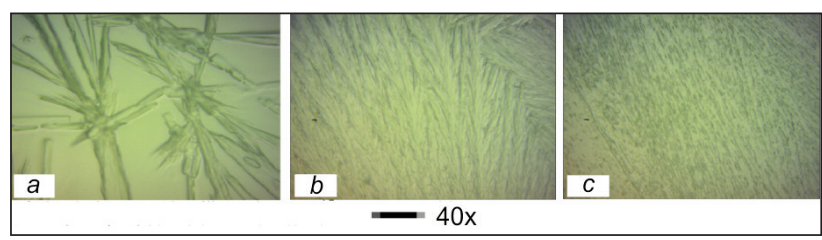

Fig. 8. Optical micrographs showing the representative morphologies resulting from three rate of urea in the paste recipe; $a-50 \mathrm{~g} / \mathrm{L}, b-100 \mathrm{~g} / \mathrm{L}$ and $c-150 \mathrm{~g} / \mathrm{L}$

urea concentration generates a film having more uniform surface. It is explained by the dominance of the sodium carbonate (figure 8) and a finer structure while increasing the urea concentration.

The effect of the urea concentration in the coating film on the drop wetting was investigated in this paragraph. Three urea concentrations were used $(50,100$ and $150 \mathrm{~g} / \mathrm{L}$ ) and others recipe constituents were constant. The figure 9 shows that the increasing of the urea concentration the amplitude of spreading remains intact. This is indicates the negligible effect of this constituent on the wetting kinetic. Therefore the evolution of the adimensional height was not affected by the urea amount variation. Then, the low variation in the adimensional volume may be explicated by the hygroscopic character of the coating film.
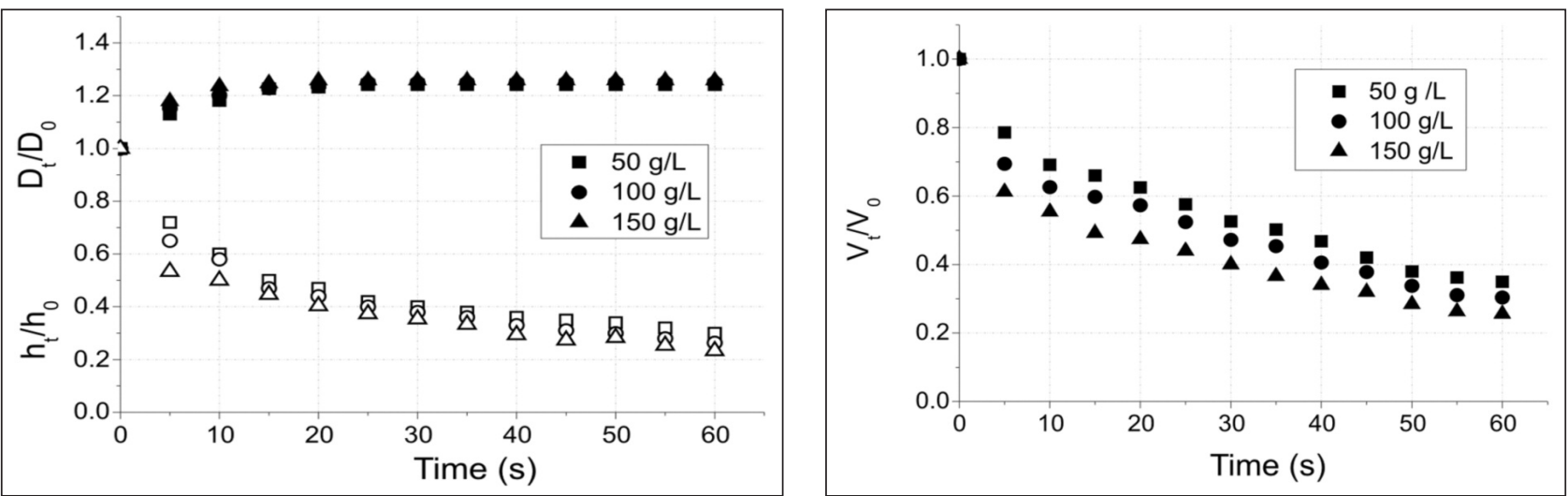

Fig. 9. Morphology-dependent wetting of the urea concentration as characterized by the time-evolution of the drop diameter, adimensional height and volume 


\section{Mathematical model}

Using Minitab software, the general behavior of the adimensional diameter can be simulated by a mathematical equation. Two types of equations can be used in order to model different responses of our study (adimensional diameter, height and volume); the linear equation (1) or the linear equation with interactions (2). Therefore, according to studied factors, different responses can be written as linear equation or linear equation with interaction as follows:

$\mathrm{D}_{\mathrm{t}} / \mathrm{D}_{0}=\mathrm{K}+\mathrm{a}_{1}$ [Thickener $]+\mathrm{a}_{2}[$ Urea $]+\mathrm{a}_{3}($ Time $)$

$\mathrm{h}_{\mathrm{t}} / \mathrm{h}_{0}=\mathrm{K}+\mathrm{b}_{1}$ [Thickener] $+\mathrm{b}_{2}$ [Urea] $+\mathrm{b}_{3}$ (Time) (1)

$\mathrm{V}_{\mathrm{t}} \mathrm{N}_{0}=\mathrm{K}+\mathrm{c}_{1}[$ Thickener $]+\mathrm{c}_{2}[$ Urea $]+\mathrm{c}_{3}$ (Time)

or,

$\mathrm{D}_{\mathrm{t}} / \mathrm{D}_{0}=\mathrm{K}_{1}+\mathrm{a}_{1}[$ Thickener $]+\mathrm{a}_{2}[$ Urea $]+\mathrm{a}_{3}($ Time $)+$

$+a_{12}$ [Thickener] $*\left[\right.$ Urea] $+a_{13}$ [Thickener] $*($ Time $)+$

$+a_{23}[$ Urea $] *$ (Time)

$\mathrm{h}_{\mathrm{t}} / \mathrm{h}_{0}=\mathrm{K}+\mathrm{b}_{1}[$ Thickener $]+\mathrm{b}_{2}[$ Urea $]+\mathrm{b}_{3}($ Time $)+$

$+b_{12}[$ Thickener $] *[$ Urea $]+b_{13}[$ Thickener $] *($ Time $)+$

$+\mathrm{b}_{23}$ [Urea] $*$ (Time)

$\mathrm{V}_{\mathrm{t}} / \mathrm{V}_{0}=\mathrm{K}+\mathrm{c}_{1}[$ Thickener $]+\mathrm{c}_{2}[$ Urea $]+\mathrm{c}_{3}($ Time $)+$

$+\mathrm{C}_{12}$ [Thickener] $*[$ Urea $]+\mathrm{C}_{13}[$ Thickener $] *($ Time $)+$

$+\mathrm{C}_{23}[$ Urea $] *$ (Time)

The results obtained for this study shows that only the regression linear terms in the model were significant and the interactions in the regression model were no significant. To evaluate the significance of each variable, the p-values lower than 0.05 indicate that the terms and the model are statistically significant. Table 3 consists of ANOVA analyze of variance of the regression model. The $p$-value, equal to zero, shows that the linear regression is very significant. Therefore, the equation of linear model without interactions was chosen to reproduce the mathematical model of the adimensional diameter, height and the volume.

The statistical technique is used to investigate and model the relationship between the response variable and the independent input factors. The model of the diameter adimensional or spreading rate $\left(D / D_{0}\right)$ is detailed in this paragraph. The input factors are the Concentration of the Thickener (CT), the Concentration of the Urea (CU) and the Time (T). These factors were evaluated by using factorial design where the main effects, interaction plot and the contour of surface of response were investigated. Main effects and the of the adimensional diameter are plotted in figure 10. The effect of the spreading phenomenon duration (time) is more important than other factors. The thickener concentration is less influential on the adimensional diameter $\left(D_{t} / D_{0}\right)$. Finally, the amount of used urea has the less effect on the drop diameter variation. It is to highlight that the time and the urea concentration have positive effect, contrarily to the quantity of thickener which has negative effect on the drop spreading phenomenon.

The study of the diagram of interactions plotted in figure 11 show parallel lines. While passing from level to

\begin{tabular}{|c|c|c|c|c|c|c|}
\hline \multicolumn{7}{|c|}{ ANOVA for the adimensional diameter $D_{t} / D_{0}$} \\
\hline Source & DF & Seq SS & Adj SS & Adj MS & $\mathrm{F}$ & $\mathrm{P}$ \\
\hline Regression & 6 & 0,408362 & 0,408362 & 0,068060 & 28,90 & 0,000 \\
\hline Linear & 3 & 0,397767 & 0,052690 & 0,017563 & 7,46 & 0,000 \\
\hline Interaction & 3 & 0,010595 & 0,010595 & 0,003532 & 1,50 & 0,230 \\
\hline Residual error & 38 & 0,089496 & 0,089496 & 0,002355 & & \\
\hline Total & 44 & 0,497858 & & & & \\
\hline \multicolumn{7}{|c|}{ ANOVA for the adimensional height $h_{t} / h_{0}$} \\
\hline Source & DF & Seq SS & Adj SS & Adj MS & $\mathrm{F}$ & $\mathrm{P}$ \\
\hline Regression & 6 & 1,91880 & 1,918796 & 0,319799 & 27,49 & 0,000 \\
\hline Linear & 3 & 1,79348 & 0,379366 & 0,126455 & 10,87 & 0,000 \\
\hline Interaction & 3 & 0,12531 & 0,125314 & 0,041771 & 3,59 & 0,062 \\
\hline Residual error & 38 & 0,44202 & 0,442023 & 0,011632 & & \\
\hline Total & 44 & 2,36082 & & & & \\
\hline \multicolumn{7}{|c|}{ ANOVA for the adimensional volume $\mathrm{V}_{\mathbf{t}} / \mathrm{V}_{0}$} \\
\hline Source & DF & Seq SS & Adj SS & Adj MS & $\mathrm{F}$ & $\mathrm{P}$ \\
\hline Regression & 6 & 1,30688 & 1,306885 & 0,217814 & 26,26 & 0,000 \\
\hline Linear & 3 & 1,23491 & 0,228613 & 0,076204 & 9,19 & 0,000 \\
\hline Interaction & 3 & 0,07198 & 0,071979 & 0,023993 & 2,89 & 0,050 \\
\hline Residual error & 38 & 0,31520 & 0,315200 & 0,008295 & & \\
\hline Total & 44 & 1,62208 & & & & \\
\hline
\end{tabular}




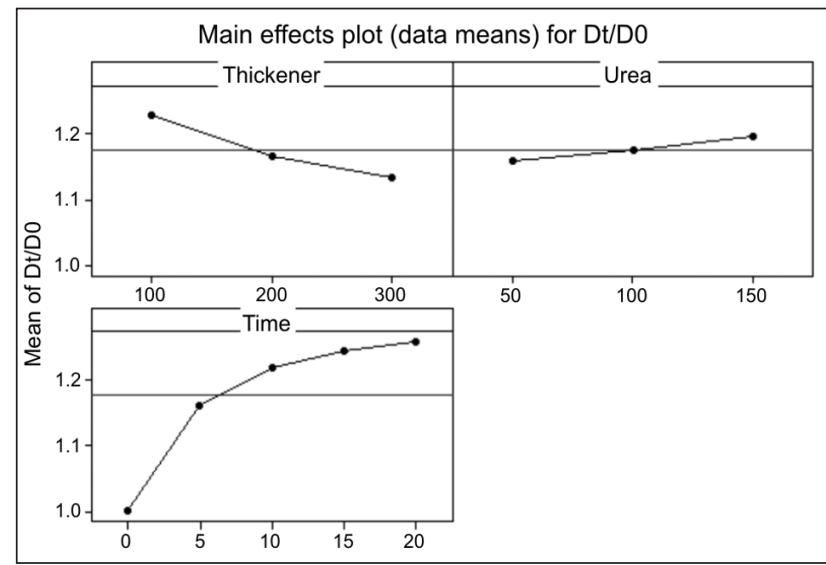

Fig. 10. Main effects diagrams for adimensional diameter at different factor

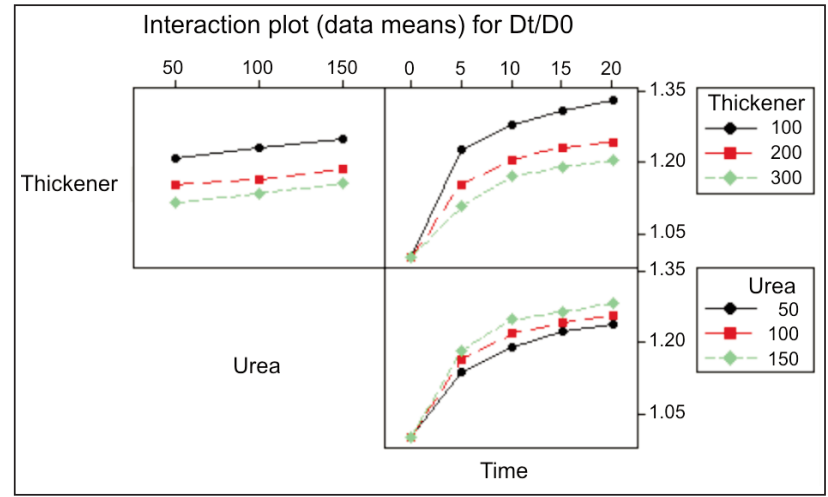

Fig. 11. Interactions diagrams for adimensional diameter at different factor

another negligible interaction was observed this is in coincidence with results obtained in table 3 . The regression equation is:

$$
\begin{gathered}
D t / D 0=1,11-0,000471[E p]+0,000375[U r]+ \\
0,0119 T
\end{gathered}
$$

Table 4

\begin{tabular}{|l|c|c|c|c|}
\hline Predictor & Coef & SE coef & T & P \\
\hline Constant & 1,11344 & 0,02853 & 39,03 & 0,000 \\
\hline$[\mathrm{Ep}]$ & $-0,00047100$ & 0,00009021 & $-5,22$ & 0,000 \\
\hline$[\mathrm{Ur}]$ & 0,0003753 & 0,0001804 & 2,08 & 0,004 \\
\hline $\mathrm{T}$ & 0,011938 & 0,001042 & 11,46 & 0,000 \\
\hline
\end{tabular}

$\mathrm{R}-\mathrm{Sq}=98,9 \%$

Table 5

\begin{tabular}{|l|c|c|c|c|c|}
\hline \multicolumn{1}{|c|}{ Source } & DF & SS & MS & F & P \\
\hline Regression & 3 & 0,39777 & 0,13259 & 54,31 & 0,000 \\
\hline Residual Error & 41 & 0,10009 & 0,00244 & & \\
\hline Total & 44 & 0,49786 & & & \\
\hline
\end{tabular}

As shown in the table, all factors are statistically significant ( $p$-value of the constant was equal to 0.000 , $p$-value of the CT factor was equal to $0.000, p$-value of the $\mathrm{CU}$ was equal to $0.004<<0.05$ and $p$-value of the $T$ was equal to 0.000 ). The regression linear model obtained by Minitab software for the diameter is very significant $(p=0.000)$ as demonstrated in the ANOVA (table 5). The regression model of the adimensional diameter is given by the following equation: The obtained components of the drop spreading diameter model show positive sign and the Time ( $T$ ) has the important constant coefficient in the equation. These observations are in coincidence with the main effects diagram.

Then, we are interested to important shutter of this study. We are attracted to application and development of the response surface method design for finding regions where there is an improvement in response and then the optimum response desired by the industrial. Figure 12 point up the contour plots which show contour lines of Concentration of the Thickener [CT] and the one of (DT) the Urea [CU] factors of the diameter. Results of the contour of the response surface showed in the variation of the diameter demonstrates that in the first time,

Then, of the same manner of the diameter, we are interested to the other wetting parameters as the height and volume. The obtained results are given in

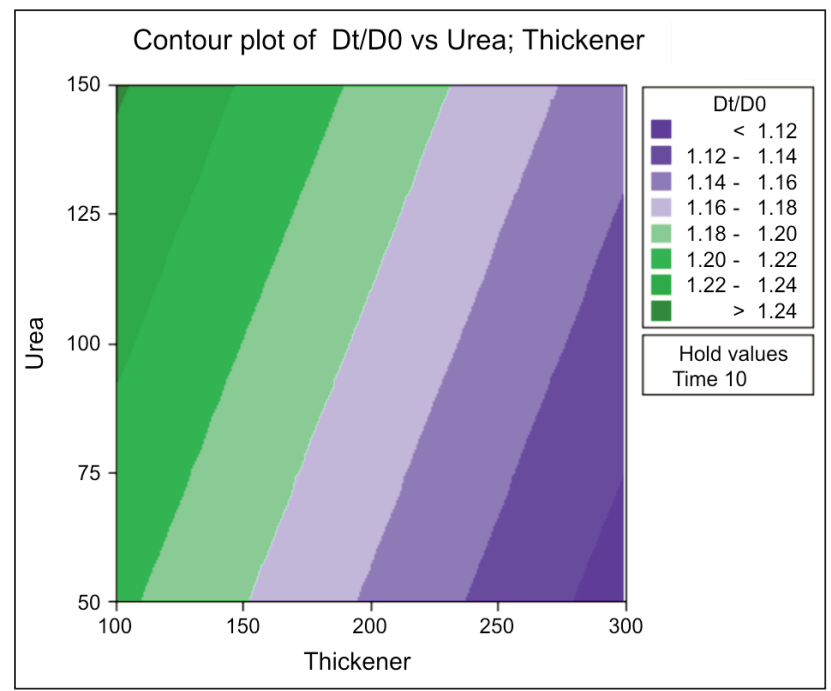

Fig. 12. Contour plot of D/D0 versus Concentration of the thickener and the concentration of the urea

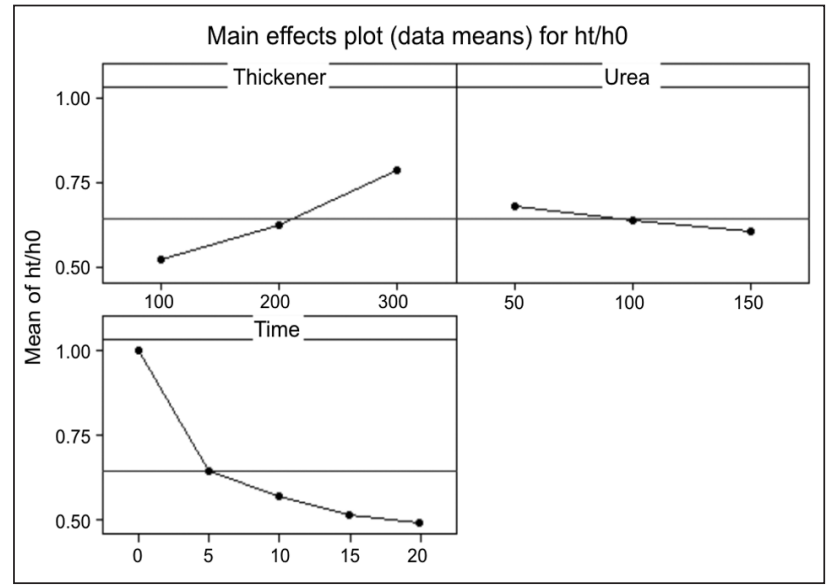

Fig. 13. Main effects for adimensional height at different factor 


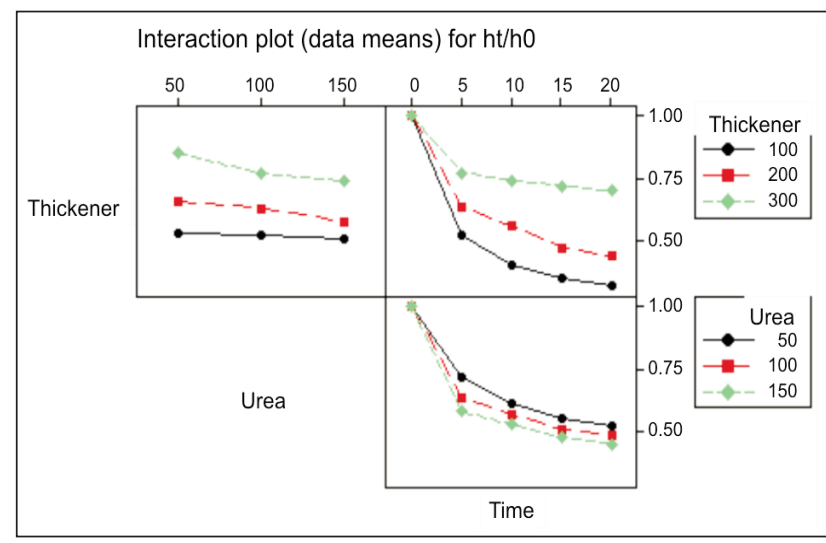

Fig. 14. Interactions diagrams for adimensional height at different factor

equations (ht/h0) and their confirmations are shown in table 6.

The regression equation is

$$
\begin{gathered}
h t / h 0=0,678+0,00135[E p]-0,000740[U r]- \\
0,0232 T
\end{gathered}
$$

Table 6

\begin{tabular}{|l|c|c|c|c|}
\hline Predictor & Coef & SE coef & T & P \\
\hline Constant & 0,67842 & 0,06791 & 9,99 & 0,000 \\
\hline$[\mathrm{Ep}]$ & 0,0013450 & 0,0002147 & 6,26 & 0,000 \\
\hline$[\mathrm{Ur}]$ & $-0,0007400$ & 0,0004295 & $-1,72$ & 0,002 \\
\hline $\mathrm{T}$ & $-0,023153$ & 0,002480 & $-9,34$ & 0,000 \\
\hline
\end{tabular}

$\mathrm{R}-\mathrm{Sq}=99 \%$

Table 7

\begin{tabular}{|l|c|c|c|c|c|}
\hline \multicolumn{1}{|c|}{ Source } & DF & SS & MS & F & P \\
\hline Regression & 3 & 1,78995 & 0,59665 & 43,13 & 0,000 \\
\hline Residual error & 41 & 0,56718 & 0,01383 & & \\
\hline Total & 44 & 2,35713 & & & \\
\hline
\end{tabular}

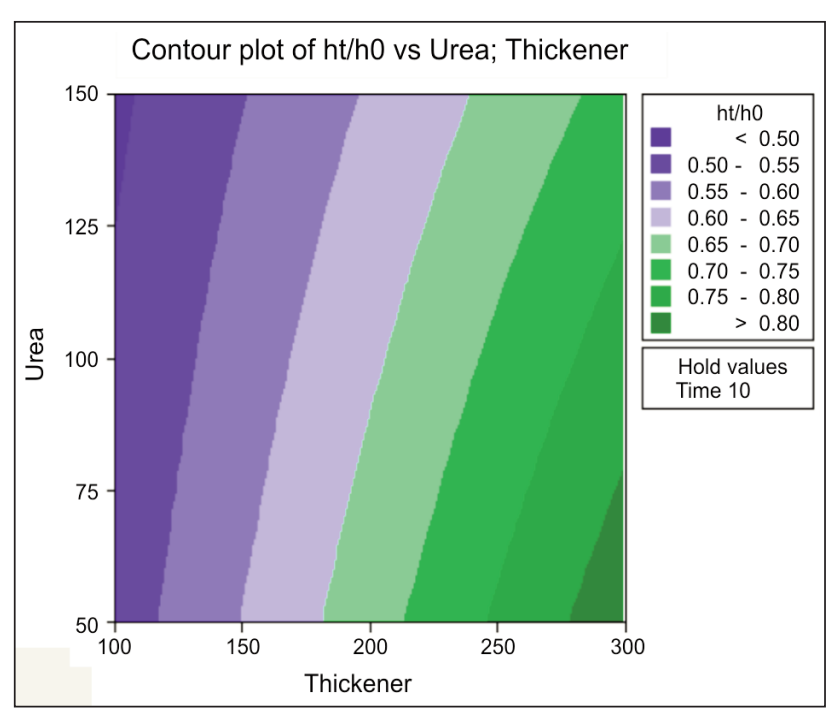

Fig. 15. Contour plot of ht/h0 versus concentration of the thickener and the concentration of the urea

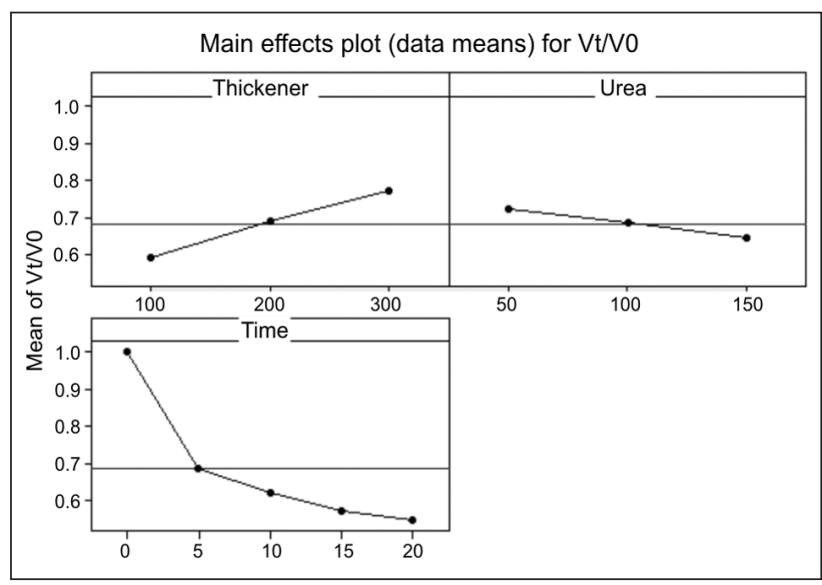

Fig. 16. Main effects for adimensional volume at different factor

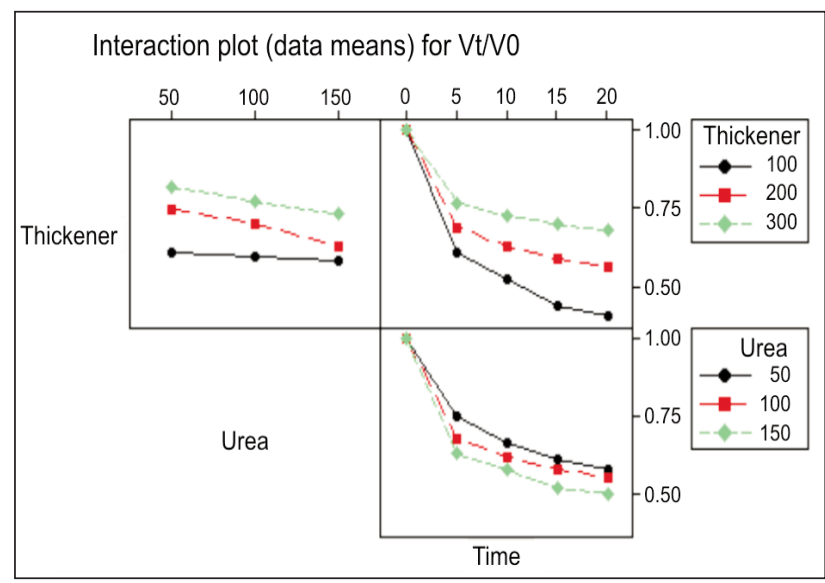

Fig. 17. Interactions diagrams for adimensional volume at different factor

The regression equation is

$V t / V 0=0,785+0,000908[E p]-0,000772[U r]-$ $0,0205 T$

Table 8

\begin{tabular}{|l|c|c|c|c|}
\hline Predictor & Coef & SE coef & T & P \\
\hline Constant & 0,78520 & 0,05608 & 14,00 & 0,000 \\
\hline$[E p]$ & 0,0009083 & 0,0001773 & 5,12 & 0,000 \\
\hline$[U r]$ & $-0,0007720$ & 0,0003547 & $-2,18$ & 0,035 \\
\hline T & $-0,020500$ & 0,002048 & $-10,01$ & 0,000 \\
\hline
\end{tabular}

$\mathrm{R}-\mathrm{Sq}=96,2 \%$

Table 9

\begin{tabular}{|l|c|c|c|c|c|}
\hline \multicolumn{1}{|c|}{ Source } & DF & SS & MS & F & P \\
\hline Regression & 3 & 1,23778 & 0,41259 & 43,73 & 0,000 \\
\hline Residual error & 41 & 0,38686 & 0,00944 & & \\
\hline Total & 44 & 1,62464 & & & \\
\hline
\end{tabular}

\section{CONCLUSIONS}

There are many complex parameters that affect characteristics of digitally printed fabrics. This paper 


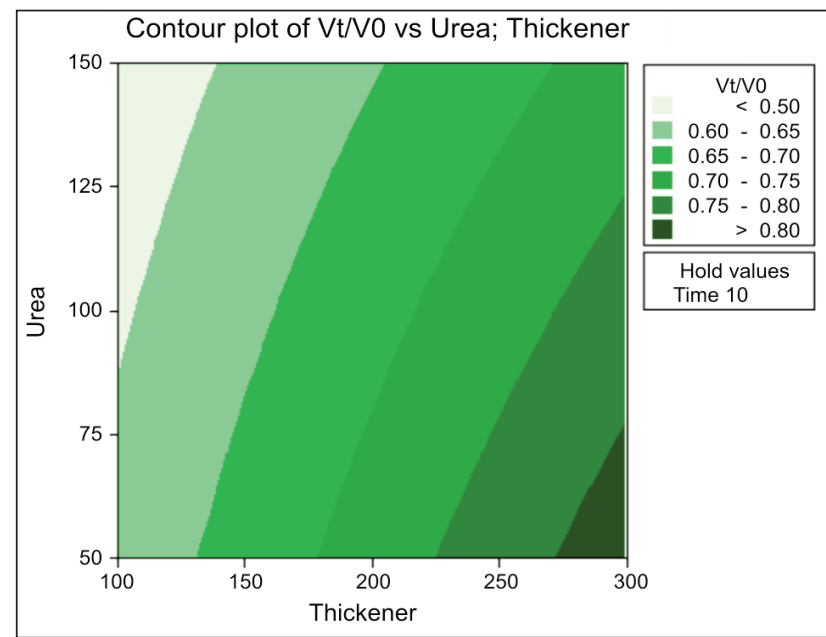

Fig. 18. Contour plot of Vt/V0 versus Concentration of the thickener and the concentration of the urea focused on the effect of film compositions on ink wetting behavior. Findings show that the drying conditions and the paste compounds affect deeply the coating film morphologies and crucially their wetting and impregnation behaviours. First, the drying conditions influence the surface morphology, therefore, especially the spreading rate. Then, the increasing of the thickener and the urea concentrations control the coating film morphology and its surface uniformity. Therefore, the thickener affects the wetting kinetic but the effect of the urea concentration on this phenomenon remains limited. Finally, the mathematical model obtained for this phenomenon is coincident with experimental results. Then, it allows us to quantify and to control various phenomena of the wetting process such as the spreading, the diffusion, the impregnation and the evaporation.

\section{BIBLIOGRAPHY}

[1] Mikuz, M., Turk, S.S. and Tavcer, P.F. Properties of ink-jet printed, ultravioletcured pigment prints in comparison with screen-printed, thermo-cured pigment prints, In: Society of Dyers and Colourists, Coloration Technology, 2010, vol. 126, pp. 249-255.

[2] Van Parys, M. The future printing will be digital, 2002, In: Melliand Textilberichte/International Textile Reports (Eng. Ed.), 83(6), E96.

[3] Gupta, S. Ink-jet printing - a revolutionary ecofriendly technique for textile printing, In: Indian Journal of Fibre \& Textile Research, 2001, vol. 26(1\&2), pp. 156-161.

[4] Gregory, P. Ink jet printing on textiles, in textile ink jet printing - A review of ink jet printing of textiles, including ITMA 2003, (T. L. Dawson and B. Glover, Eds.); In: Society of Dyers and Colourists, Technical Monograph, 2004, pp. 69-97.

[5] Choi, P.S., Yuen, C.W.M., Ku S.K.A. and Kwan, C.W. Ink-jet printing for textiles, In: Textile Asia, 2003, vol. 34 (10), pp. 21-24.

[6] Byrne, C. Textile ink jet printing-market information, potential outlets and trends, In: Textile Ink Jet printing - A review of ink jet printing of textiles, including ITMA 2003, (T. L. Dawson and B. Glover, Eds.). In: Society of Dyers and Colourists Technical Monograph, 2004, pp. 30-37.

[7] Dawson, T.L. Ink-jet printing of textiles under the microscope. In: Journal of the Society of Dyers and Colourists, 2000. Vol. 116, pp. 52-59.

[8] Mikuz, M., Sostar-Turk S. and Pogacar, V. Fibres Textiles, In: Eastern Europe, 2005, vol. 13 6(54), pp. $79-84$.

[9] Zhang, Y., Westland, S., Cheung, V., Burkinshaw S.M. and Blackburn, R.S. A custom ink-jet printing system using a novel pretreatment method, In: Coloration Technology, 2009, vol. 125(6), pp. 357-365.

[10] Ervine, S., Siemensmeyer, K., Siegel, B. A simple, universal approach to ink jet textile fabrics, In: Textile Chemist and Colorist and American Dyestuff Reporter, 2000, vol. 32(10), pp. 26-27.

[11] Fan, Q., Kim, Y.K., Lewis, A.F. and Perruzi, M.K. Fabric pretreatments and digital textile print quality, In: Journal of Imaging Science and Technology, 2003, vol. 47, pp. 400-407.

[12] Yuen, C.W.M., Ku, S.K.A., Kan, C.W. and Choin, P.S.R. Study of factors influencing color yield of an ink-jet printed cotton fabric, In: Coloration Technology, 2004, vol. 120, pp. 320-325.

[13] Yuen, C.W.M., Ku, S.K.A., Choin, P.S.R. and Kan, C.W. The effect of the pretreatment print paste contents on color yield of an ink-jet printed cotton fabric, In: Fibers and Polymers, 2004, vol. 5, pp. 117-121.

[14] Yuen, C.W.M., Ku, S.K.A., Kan, C.W. and Choin, P.S.R. Enhancing textile ink-jet printing with chitosan, In: Coloration Technology, 2007, vol. 123, pp. 267-270.

[15] Yuen, C.W.M., Ku, S.K.A., Kan and Kan, C.W. Use of biomaterial as a thickener for textile ink-jet printing, In: Journal of Applied Polymer Science, 2008, vol.107, pp. 1057-1065.

[16] Bahmani, S.A., East, G.C. and Holme, I. The application of chitosan in pigment printing, In: Journal of the Society of Dyers and Colourists, 2000, vol. 116(3), pp. 94-100.

[17] Abou-Okeil, A. and Hakeim, O.A. Effect of metal ion binding of chitosan on the printability of pretreated wool fabric, In: Coloration and Technology, 2005, vol. 121(1), pp. 41-44.

[18] Choin, P.S.R., Yuen, C.W.M., Ku, S.K.A. and Kan, C.W. Digital ink-jet printing for chitosan-treated cotton fabric, In: Fibers and Polymers, 2005, vol. 6(3), pp. 229-234. 
[19] de Gans, B.J. and Schubert, U.S. Inkjet printing of well-defined polymer dots and arrays, In: Langmuir, 2004, vol. 20, pp. 7789-7793.

[20] Soltman, D. and Subramanian, V. Inkjet-printed line morphologies and temperature control of the coffee ring effect, In: Langmuir, 2008, vol. 24, pp. 2224-2231.

[21] Kagami, H. Thickness control of a thin film after drying through thermal and evaporative management in drying process of a polymer solution coated on a flat substrate: application of the dynamical model of the drying process, In: The Proceeding of SPIE., 2011, 8068, 806813-1 - 6.

[22] Kagami H. and Kubota, H. A dynamical model of drying process of a polymer solution having plural solvents and plural solutes (polymers) coated on a flat substrate for a flat and homogeneous polymer film fabrication, In: Physica Status Solidi, (C) Current Topics in Solid State Physics, 2011, vol. 8(2), pp. 586-588.

[23] Kagami, H. More minute thickness control of a thin film after drying through temperature, evaporation and concentration management in drying process of a polymer solution coated on a flat substrate, In: Proceedings of the 19th International Drying Symposium, Lyon, August 24-27, 2014, ISBN 978-2-7598-1631-6.

[24] Kagami, H. Impact of the Marangoni effect on the thin film thickness profile after drying polymer solution coated on a flat substrate, In: Journal of the Physical Society of Japan; Conferences Proceeding, 2014b, 1, 015087-1 - 5.

[25] Achour, N.S., Baffoun, A., Hamdaoui, M. and Nasrallah. S.B. Effect of knitted parameters on wicking behaviours, In: Industria Textila, 2016, vol. 67 (2), pp. 99-102.

[26] Fan, Q., Kim, Y.K., Lewis, A.F. and Perruzzi, M.K. Effects of pretreatments on print qualities of digital textile printing, In: NIP 18, International Conference on Digital Printing Technologies, 2002, pp. 236-241, San Diego, CA, USA.

[27] Q Fan, Q., Kim, Y.K., Lewis, A.F. and Perruzzi, M.K. Fabric pretreatment and digital textile print quality. In: Journal of Imaging Science and Technology, 2003, vol. 47, p. 400.

[28] Park, H., Car, W.W., OK, H. and Park, S. Image quality of inkjet printing on polyester fabrics, In: Textile Research Journal, 2006, vol. 76, pp. 720-728.

Authors:

\section{ZOUHAIER ROMDHANI ${ }^{1,2}$ \\ MOHAMED HAMDAOUI ${ }^{2}$ \\ AMAL CHEBIL ${ }^{2}$ \\ MUSTAPHA JENDOUBI ${ }^{3}$}

${ }^{1}$ Laboratory of Interfaces and Advanced Materials (L.I.M.A),

Faculty of Sciences of Monastir - University of Monastir - Tunisia

${ }^{2}$ Textile Materials and Process Research Unit, University of Monastir - Tunisia

${ }^{3}$ Textile Industrial Company (ITS), Monastir - Tunisia

e-mail: romdhanizouhaier@gmail.com, hamdaouimohamed@yahoo.fr, ammoulachebil@gmail.com

Corresponding author:

AMAL CHEBIL

e-mail: ammoulachebil@gmail.com 


\section{Formalizing the conceptual-applicative framework of smart textile fibers in medicine}

DIANA LORETA PĂUN

DOI: 10.35530/IT.069.01.1458

CONSTANTIN SORIN PĂUN

EMILIA VISILEANU

LAURENȚIU ALEXANDRU CHIOTOROIU

SILVIA CHIOTOROIU

REZUMAT - ABSTRACT

\section{Formalizarea cadrului conceptual-aplicativ al fibrelor textile inteligente în medicină}

Articolul abordează probleme legate de domeniul disciplinar al chirurgiei medicale, care impune caracteristici deosebite ale fibrelor, cu potențial fizico-chimic și proprietăți de rezistență puternic controlate. Clasificările propuse și liniile de abordare a fibrelor textile în medicina generală și, în particular, în chirurgie, sunt de natură teleologică și, în egală măsură, reprezintă premise pentru o taxonometrie generică în domeniu. Propunerea originală în acest cadru este de abordare extinsă a multi-tipo-dimensiunilor de fire chirurgicale în intervențile clinice specifice, pornind de la constatarea că, în fapt, cantonarea în tipo-dimensiunea fixă/forma exclusivă circulară a firului chirurgical înseamnă stagnare, temperarea inovarii de granita în domeniu.

Cuvinte-cheie: industria textilă, fibre textile inteligente în medicină, taxonometrie generică în domeniu

Formalizing the conceptual-applicative framework of smart textile fibers in medicine

The article addresses issues related to the discipline of medical surgery requiring special fiber features with physicochemical material potential and strongly controlled resistance properties. The proposed classifications and lines of approach of textile fibers in general medicine, and in particular in surgery, are of a teleological nature and equally are prerequisites for generic taxonomy in the field. The original proposal in this context is to expand the multi-type dimension of surgical wounds in specific clinical operations, starting from the finding that in fact cantoning in the fixed-type size/exclusive circular shape of the surgical thread means stagnation, moderation of innovation of rupture in the field.

Keywords: textile industry, smart textile fibers in medicine, generic taxonomy in the field

\section{INTRODUCTION}

The use of textile materials (fibers, fabrics, yarns, bands, etc.) in preclinical and clinical medicine implies a feasible knowledge of: 1) the physic-chemical properties of the textile material, 2) the structure explained by the properties, 3 ) the chain of molecules in the fibers of the fabric, 4) the considerable effects induced on the human body at the "fiber-skin" contact in surgery, etc. Textile fiber is the natural, artificial or composite material characterized by its long length, extremely low thickness (thinness), fineness and flexibility. It is recognized that in the usual manufacturing of textiles system, artificial polymers play a decisive role in vinyl (including acrylic), polyamides, polyolefin, polyesters, to which natural polymers, namely proteins and cellulose, are added. In clinical medicine, from the perspective of physical properties, basic requirements for textile fibers are imposed starting from: 1) breaking strength, 2) continuity, 3) as long as possible, 4) extensibility, 5) elasticity. In medicine, in our opinion, it is of interest to use "smart fibers" that could translate various values of medical knowledge recorded in surgical sites in the human body.

\section{RELATED LITERATURE}

In papers elaborated by Hearle J.W.S. and Morton W.E. (2008), [6], Horrocks A.R. and Anand S.C., (2000), [7], Dattilo P. et al., (2002), [3], Nelson G., (2002), [11], Czajka R., (2005), [2], Tao X., (2001),
[12], etc. there are presentations, descriptions, assertions, conceptual and practical approaches to textile fibers used increasingly in medicine. Intelligent/ smart textile and clothing are topics described by Mattila H., (2006), [10], also van Langenhove L., (2007), [13], describes significantly aspects related to smart textiles for medicine and healthcare. Particular concerns in the field are also found in the works carried out by Anand S.C., et al., (2005), [1], respectively Lymberis A. and Olsson S., (2003), [9], which highlights the role of biomaterials in the smart biomedical area. A particular sub-domain is that of the yarns of surgery textile fibres for suture. Textile surgical implants are used in methods of intracorporeally suturing issues (Ellis J.G., 2013), [4], which add method of attaching surgical needles to multifilament polyglycolic acid absorbable sutures (Epstein M. and Schmidt E., 1971), [5] It can be noticed that the scientific literature in the field has updated topics, and fiber textiles are perfected in line with the accelerated technological progress in invasive/non-invasive medicine.

\section{EXPERIMENTAL WORK}

\section{Methods, classification and specific remarks}

Some polysaccharide-type fibrous substances found in "chitin" are medical uses by derivative chitosan. In the context, the constituent presence of alginic acid occurs when the fibers obtained are highly crystalline 


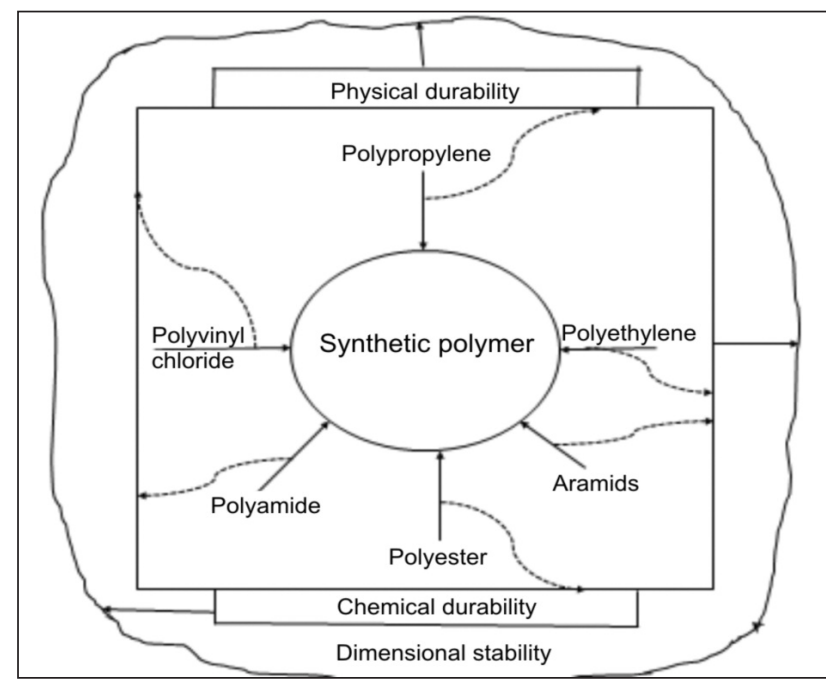

Fig. 1. Suitable synthetic polymers for medium to long applications in civil and agricultural engineering (Source: Authors, 2017)

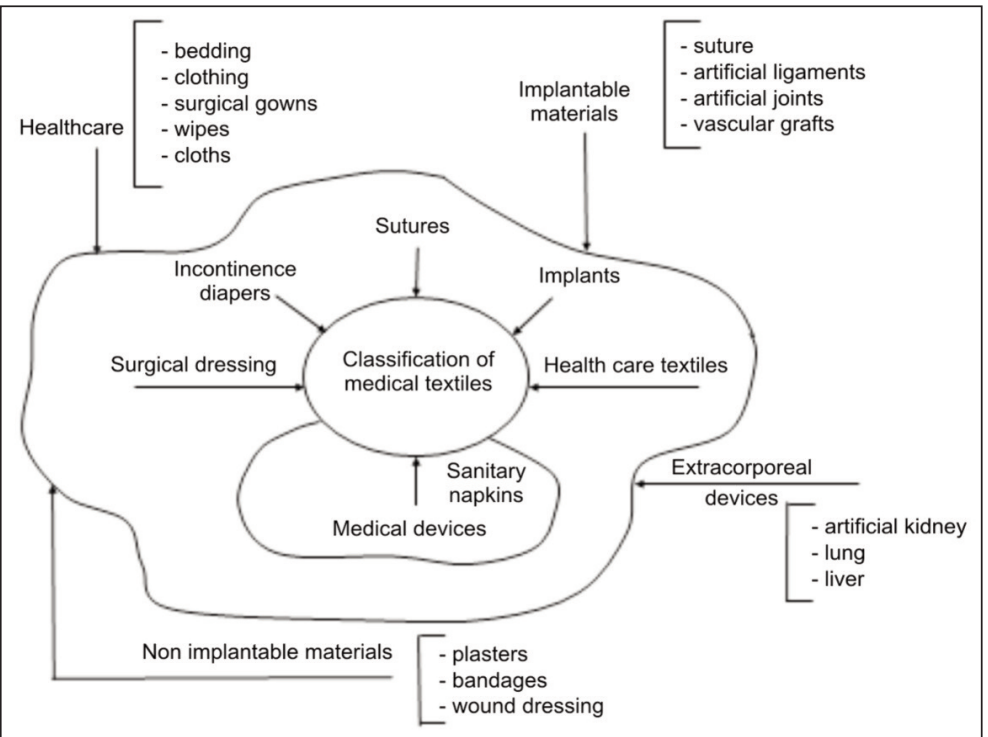

Fig. 2. Characterization of classification of medical textiles (Source: Authors, 2017)

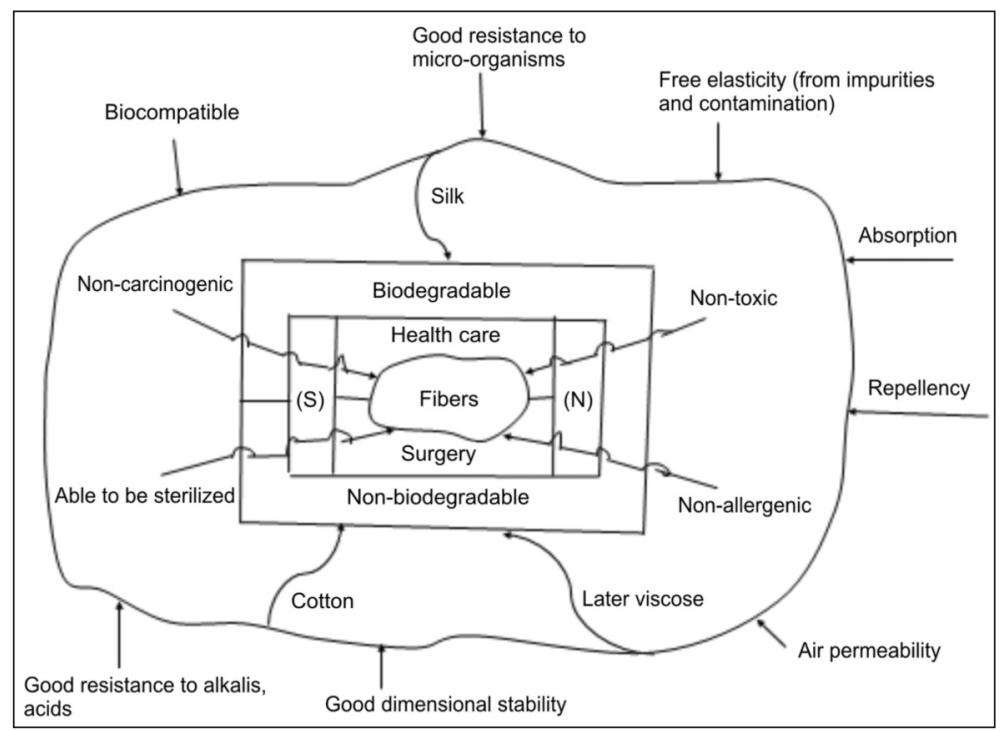

Fig. 3 Characteristics of textile fibers (types) used in health care and surgery. (Source: Authors, 2017) and real oriented. These yarns are subject to degradation because of their acidity, but different metal salts neutralize their rate of dissolution/disappearance. Medical fibers require biological compatibility. In the context, "smart fibers" have to prove special properties that mainly refer to radiation-absorbing, biological, electrical, diffusion, magnetic, etc. They could serve as thermo regulators, responsive to various stimuli, passive electronic instruments, transducers, etc. It is already recognized that certain substances/piezoelectric materials such as polyvinyl fluorides $\left(\mathrm{CH}_{2}-\mathrm{CF}_{2}\right)$ prove piezoelectric properties, configuring classes of particular polymers, and the addition of carbon to provide electrical conduction improves their range of uses in medicine. It is worth noting that in addition to the chemical and physicmechanical properties, the dimensions of medical textile fibers are of crucial importance in modern medical applications. Optimum lengths of $1-10 \mathrm{~cm}$, $0.1 \mathrm{~mm}$ convolution spacing, 10 micrometer diameter diameters, lamination up to 0.1 micrometers, making micro-fibrils with non-crystalline or crystalline areas with dimensions of $10 \mathrm{~nm}$ are dimensional requirements/already generally required for textile fibers used in medicine. Moreover, it reaches this frame and dimensions such as molecular width of $1 \mathrm{~nm}$, knowing that atoms of $\mathrm{C}, \mathrm{N}, \mathrm{O}, \mathrm{H}$ can reach $1 \AA\left(10^{-8}\right.$ $\mathrm{cm})$. In the traditional view, when the fibers are in the group it is appreciated that long fibers ensure cohesion, and short fibers sustain breaks. Typically, the fibers are present as amorphous sub-portions that support infrastructures: a) partially crystalline, b) linear polymers or c) partially oriented. Jeffries R., et al. (1969) [8], shows that structural clutter can occur in the textile material, for example when natural polymers such as celluloses are contacted with various other degradation substances. The author shows, by way of example, that the cotton effects in disordered textiles are: nonfreezing water $(16 \%)$, acid hydrolysis $(10 \%)$, alcoholysis $(10 \%)$, dinitrogen tetroxide oxidation $43 \%$ ), iodine sorption $(13 \%)$, etc. We find that synthetic polymers found in artificial textile fibers have applications in civil and agricultural engineering (figure 1).

Combination of medical science and textile technology offers a new research alignment and applications for medical textiles. We note, however, that the development of new fibers is conditional on manufacturing technologies (figure 2).

The disciplinary field of medical surgery requires, however, special features regarding fiber, which must have physic-chemical material potential and strongly controlled resistance properties (figure 3 ). 


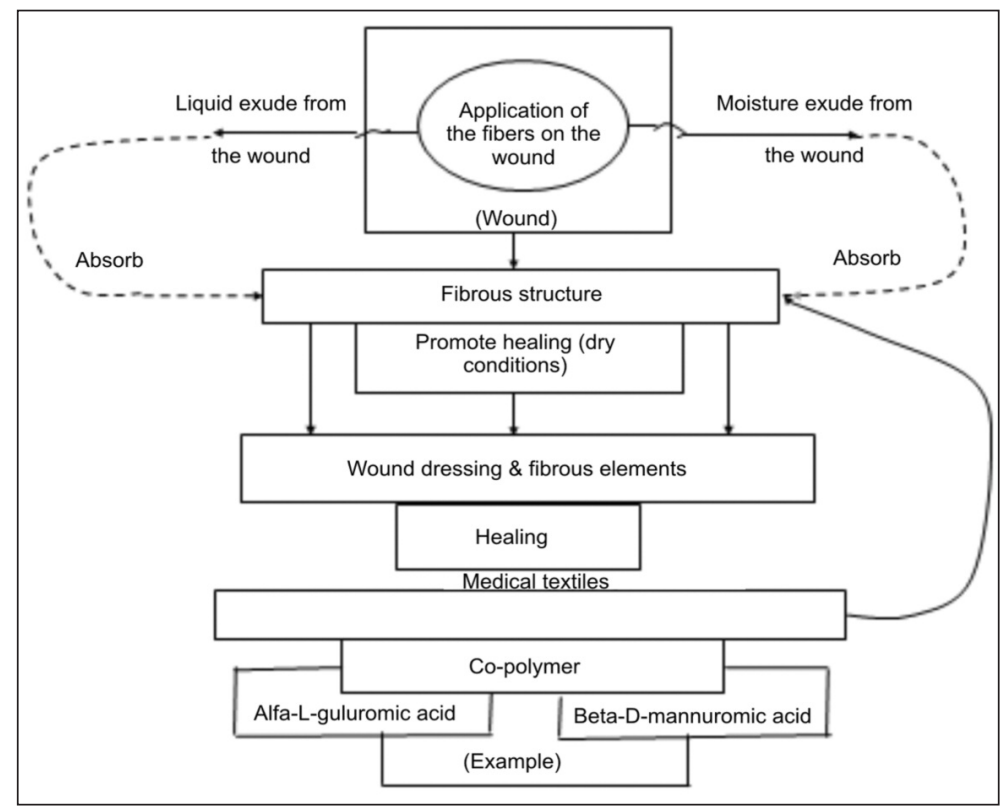

Fig. 4. Conditions of fibrous structure to respond compliant to applications on the wound. (Source: Authors, 2017)

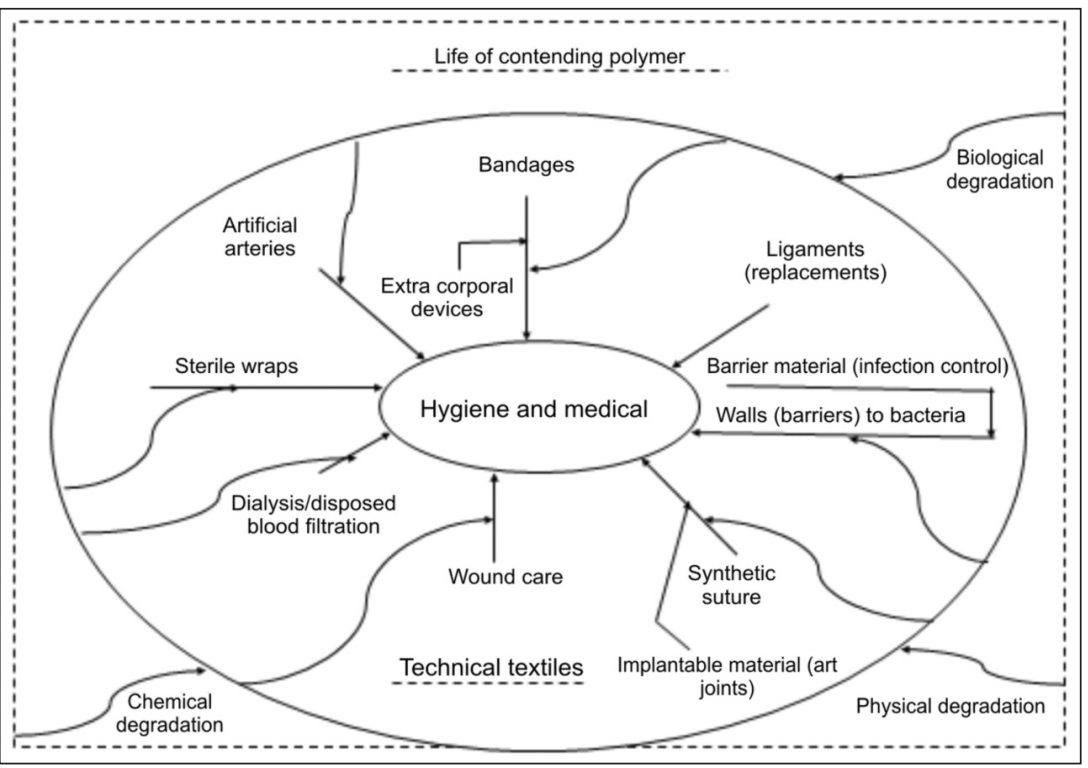

Fig. 5. Application of technical textile in hygiene and medical. (Source: Authors, 2017)

In the context, the fibrous structure must respond with real physical compatibility to the applications on the wound (figure 4).

In the same general medical framework, special textile fibers must respond with specific compatibility with the health and medical conditions (figure 5).

The above proposed classifications and lines for approaching textile fibers in general medicine, and in particular in surgery, are of a teleological nature and equally are prerequisites for generic taxonomy in the art.

\section{RESULTS AND DEBATES}

Characterization of intelligent/smart yarns/fibers in surgery operations

In surgery, the specific yarns/fibers used have the circular section, in all the usual cases, for all types of interventions known in the present, when there is a need for osmotic articulation of the different portions of the human body upon which incision has occurred. Circular sections $\left(S_{c}\right)$ are calculated with the relationship:

$$
\left(S_{c}\right)=\pi r^{2}
$$

with $r=$ radius (1/2 of the thickness) of the textile thread.

In the context, for a range $(0, \ldots, 1)$ it is possible to vary the circular section (thickness) as follows:

$$
\left(S_{c}\right)_{0}-\left(S_{c}\right)_{i}=\left(\pi r^{2}\right)_{0}-\left(\pi r^{2}\right)_{1}
$$

with the conditions:

$$
\text { 1) } \begin{array}{r}
r_{0}>r_{i} \sim\left(S_{c}\right)_{0}>\left(S_{c}\right)_{i}=\text { decreasing } \\
\text { thickness, (i) }
\end{array} \text { 2) } \begin{array}{r}
r_{0}=r_{i} \sim\left(S_{c}\right)_{0}=\left(S_{c}\right)_{i}=\text { maintaining } \\
\text { thickness, (ii) }
\end{array}
$$

The surgical user's case of special thread working in the operating theaters shows the quasi-absolute frequency of the situation (ii). Our proposal in this traditional setting is to expand the multi-type dimension of surgical thread in specific clinical operations, starting from the finding that in fact cantoning in the fixedtype size/exclusive circular shape of the surgical thread means stagnation, breakthrough innovations in the field. The advantages of such an approach are to establish an optimal linear density through the longitudinal variation of the size of the surgical cord radius, creating optimized quantitative desorption conditions in a controlled time. Next, it is possible to switch to the geometrical remodeling of the section of the surgical wires, reaching the ellipsoidal, rectangular, square, or irregular shapes of the sections, which, in accordance with the requirements of the surgical operations would mean the revolution of the products of this type in the field, chosen when feasible solutions are found for the biological degradation of technical textiles (figure 6).

In fact, we have to deal with the harmonization of the former sectional of the surgical thread with surgical suture requirements so that quantitatively and in time to provide optimized alignments for controlled, effective resorbtions. Some properties, such as torsional rigidity, degree of thickening, in/non-uniformity, variability of fineness, etc. are otherwise perceived/measured when considering transverse forms and dimensions. 


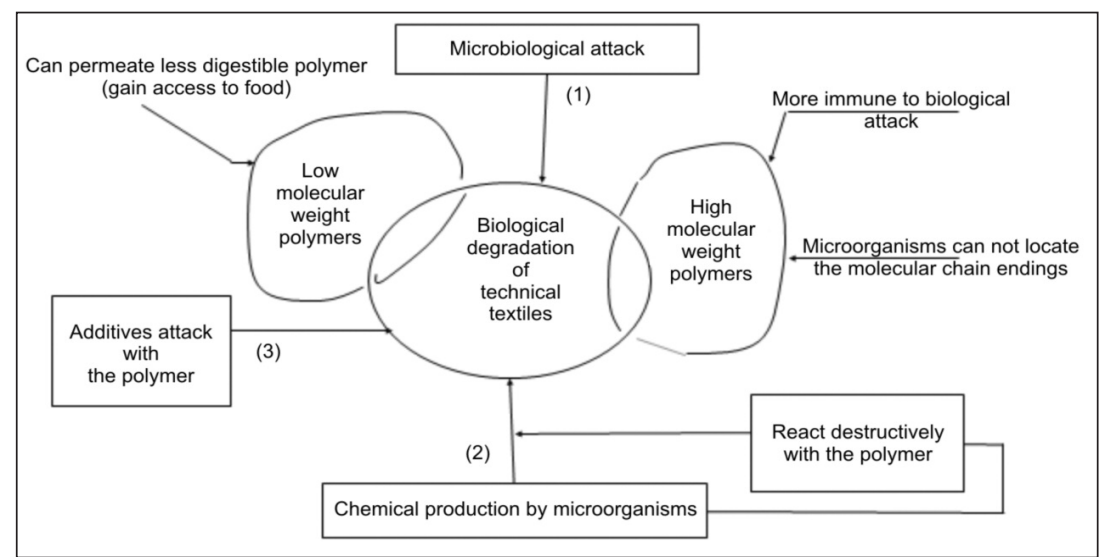

Fig. 6. Some issues on biological degradation in medical of technical textiles. (Source: Authors, 2017)

\section{CONCLUSIONS}

Geometric remodeling of the section of surgical wires means reaching the ellipsoidal, rectangular, square, or irregular sections of the sections. The requirements of the surgical operations are fulfilled and the products of this type are revolutionized in the field, for the biological degradation of technical textiles. The disciplinary field of medical surgery requires, however, special featurels regarding fiber, which must have physicochemical material potential and strongly controlled resistance properties. In the field of health, there are up-to-date topics, and fiber textiles are refined in line with advances in information technology accelerated in invasive/non-invasive medicine. It is recommended that an extended approach of multitype-sized surgical wires be performed in specific clinical surgery operations.

\section{BIBLIOGRAPHY}

[1] Anand, S.C., et al. Medical textile and biomaterials for helthcare, In: The Textile Institute, Woodhead PL, Cambridge, 2005.

[2] Czajka, R. Development of medical textile market, In: Fibres and Textiles in Eastern Europe, January/March 2005, vol. 13 , no. $1 / 49$.

[3] Dattilo, P. et al. Medical textiles application of an absorbable barbed bi-directinal surgical suture, In: Journal of Textile and Apparel, Technology and aManagement, vol. 2, Issue 2, Spring 2002.

[4] Ellis, J.G. US Patent, No. US5990378A, Mars 2013.

[5] Epstein, M., Schmidt, E. US Patent, No. US3736646A, 1971.

[6] Hearle, J.W.S., Morton, W.E. eds. Physical proprieties of textile fibres, In: The Textile Institute, Woodhead PL, Cambridge, 2008.

[7] Horrocks, A.R., Anand, S.C. Handbook of technical textiles, In: The Textil Institute, Woodhead PL, Cambridge, 2000.

[8] Jeffries, R., et al. Cell, Chem. Technol., 1969, 3, 255.

[9] Lymberis, A., Olsson, S. Intelligent biomedical clothing for personal health and disease management: state of art and future vision, telemedicine, In: Journal of e-health, vol. 9, Issue 4, December 2003, pp. 379-386.

[10] Mattila, H. Intelligent textile and clothing, In: The Textile Institute, Woodhead PL, Cambridge, 2006.

[11] Nelson, G. Application of microencapsulation in textiles, In: Intl. J. of Pharmaceutics, vol. 242, Issues 1-2, August 2002, pp. 55-62.

[12] Tao, X. Smart fibres, fabrics and clothing: fundamentals and application, In: The Textile Institute, Woodhead PL, Cambridge, 2001.

[13] van Langenhove, L. Smart textiles for medicine and healthcare: Materials, Systems and Applications, In: The Textile Institute, Woodhead PL, Cambridge, 2007.

\section{Authors:}

\section{DIANA LORETA PĂUN 1 , CONSTANTIN SORIN PĂUN², LAURENȚIU ALEXANDRU CHIOTOROIU³, EMILIA VISILEANU 4 , SILVIA CHIOTOROIU ${ }^{5}$}

${ }^{1}$ Senior Lecturer, Dr., PhD in Medicine, Carol Davila University of Medicine and Pharmacy, Bucharest / Manager National Institute of Endocrinology C.I. Parhon, Bucharest, 34-36 Bd. Aviatorilor, 011863, Bucharest, Romania

${ }^{2}$ Lecturer, Dr., PhD in Medicine, Carol Davila University of Medicine and Pharmacy, Bucharest / Floreasca Hospital, Bucharest, 8 Floreasca St., 014461, Bucharest, Romania

${ }^{3}$ Dr., PhD in Medicine, Floreasca Hospital Bucharest, 9 Floreasca St., 014461, Bucharest, Romania

${ }^{4} \mathrm{PhD}$. Engineering, Senior Researcher, I Dgr. Sci. Resch INCDTP, Bucharest, Romania

${ }^{5}$ Dr., PhD in Medicine, Malaxa Hospital, Bucharest, 12 Vergului St., 022441, Bucharest, Romania

e-mail: dianaloreta_paun@yahoo.ro,drspaun@yahoo.ro, chiotoroiu@yahoo.com,

visilean@ns.certex.ro, chiotoroiu@yahoo.com

Corresponding author:

LAURENȚIU ALEXANDRU CHIOTOROIU

e-mail: chiotoroiu@yahoo.com 